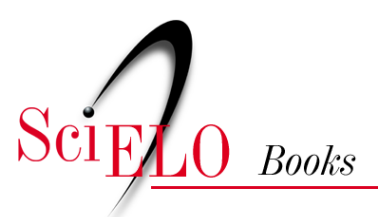

\title{
Whatsapp e educação entre mensagens, imagens e sons
}

\author{
Cristiane Porto \\ Kaio Eduardo Oliveira \\ Alexandre Chagas \\ (Organizadores)
}

PORTO, C., OLIVEIRA, K.E., and CHAGAS, A., comp. Whatsapp e educação: entre mensagens, imagens e sons [online]. Salvador: Ilhéus: EDUFBA; EDITUS, 2017, 302 p. ISBN 978-85-232-2020-4. https://doi.org/10.7476/9788523220204.

All the contents of this work, except where otherwise noted, is licensed under a Creative Commons Attribution 4.0 International license.

Todo o conteúdo deste trabalho, exceto quando houver ressalva, é publicado sob a licença Creative Commons Atribição 4.0. 


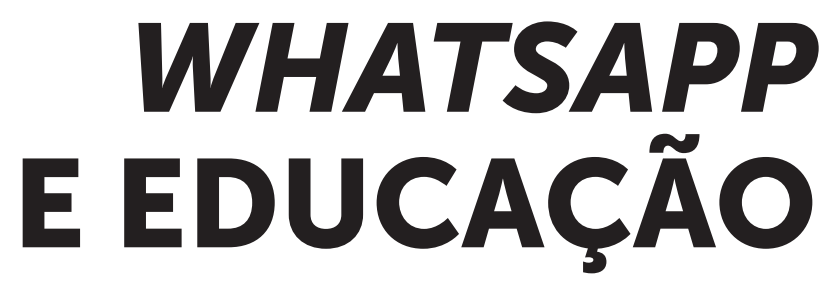

Entre mensagens, imagens e sons 


\section{UNIVERSIDADE FEDERAL DA BAHIA}

\section{Reitor}

João Carlos Salles Pires da Silva

\section{Vice-reitor}

Paulo Cesar Miguez de Oliveira

Universidade Estadual de Santa Cruz

Assessor do Reitor

Paulo Costa Lima

GOVERNO DO ESTADO DA BAHIA

Rui Costa - Governador

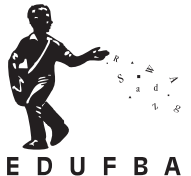

SECRETARIA DE EDUCAÇÁO

Walter Pinheiro - Secretário

UNIVERSIDADE ESTADUAL DE SANTA CRUZ

EDITORA DA UNIVERSIDADE FEDERAL DA BAHIA

DIRETORA DA EDITUS

\section{Diretora}

Flávia Goulart Mota Garcia Rosa

Rita Virginia Alves Santos Argollo

\section{Conselho Editorial}

Alberto Brum Novaes

Angelo Szaniecki Perret Serpa

Caiuby Álves da Costa

Charbel Niño El Hani

Cleise Furtado Mendes

Dante Eustachio Lucchesi Ramacciotti

Evelina de Carvalho Sá Hoisel

José Teixeira Cavalcante Filho

Maria do Carmo Soares de Freitas

Maria Vidal de Negreiros Camargo

Conselho Editorial:

Rita Virginia Alves Santos Argollo - Presidente Evandro Sena Freire Luciana Sedano de Souza Eduardo Lopes Piris Lessí Inês Farias Pinheiro Rita Jaqueline Nogueira Chiapetti Jorge Henrique de Oliveira Sales

Guilhardes de Jesus Júnior Alexandra Marselha Siqueira Pitolli Josefa Sônia Pereira da Fonseca Ricardo Matos Santana Maria Luiza Silva Santos Lurdes Bertol Rocha 


\section{CRISTIANE PORTO \\ KAIO EDUARDO OLIVEIRA \\ ALEXANDRE CHAGAS \\ (Organizadores)}

\section{WHATSAPP \\ E EDUCAÇÃO}

Entre mensagens, imagens e sons

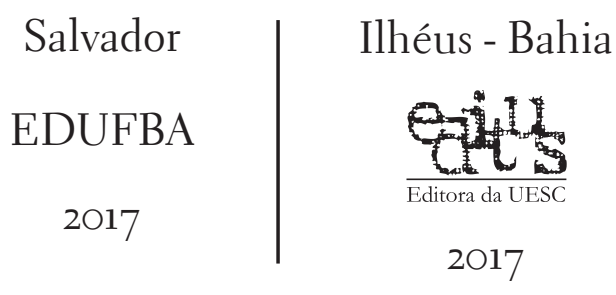


Direitos desta edição reservados à EDITUS - EDITORA DA UESC

A reproduçáo não autorizada desta publicaçáo, por qualquer meio, seja total ou parcial, constitui violaçáo da Lei no 9.610/98.

Depósito legal na Biblioteca Nacional, conforme Lei no 10.994 , de 14 de dezembro de 2004.

PROJETO GRÁFICO E DIAGRAMAÇÃO
Linda Barros

CAPA

Equipe Edunit

REVISÃO

Roberto Santos de Carvalho

Dados Internacionais de Catalogação na Publicação (CIP)

W324 Whatsapp e educação: entre mensagens, imagens e sons / Cristiane Porto, Kaio Eduardo Oliveira, Alexandre Chagas, organizadores. - Salvador : Ilhéus : EDUFBA; EDITUS, 2017.

302p. il.

\section{ISBN 978-85-232-1668-9}

1.Educaçáo. 2. Pedagogia. 3. Educação-tecnologia da informação. 4. Educaçâo - redes sociais on-line. I. Porto, Cristiane. II. Oliveira, Kaio Eduardo. III. Chagas,' Alexandre. IV. Título.

EDITUS - EDITORA DA UESC

Universidade Estadual de Santa Cruz Rodovia Jorge Amado, km 16 - 45662-90o Ilhéus, Bahia, Brasil Tel.: (73) 3680-5028 www.uesc.br/editora editus@uesc.br

EDITORA FILIADA À

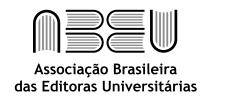

\section{EDITORA DA UFBA}

Rua Barão de Jeremoabo

$\mathrm{s} / \mathrm{n}$ - Campus de Ondina 40170-115 - Salvador - Bahia

Fax: +55 71 3283-6160 www.edufba.ufba.br edufba@ufba.br

EDITORA FILIADA À

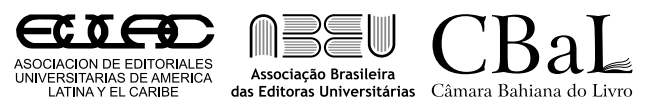




\section{SUMÁRIO}

EDUCAÇÃO MEDIADA PELO WHATSAPP: ENSINAR E APRENDER POR MENSAGENS INSTANTÂNEAS

Cristiane Porto - UNIT

Kaio Eduardo Oliveira - UNIT

Alexandre Chagas - UNIT

PREFÁCIO

PAULO FREIRE, VYGOTSKY, FREINET, DEWEY E ANÍSIO TEIXEIRA USARIAM O WHATSAPP!

Marco Silva - UERJ

\section{TEMA 1 - WHATSAPP, MEDIAÇÃO E PROCESSOS COMUNICATIVOS}

GESTÃO EM REDE NA PRIMAVERA SECUNDARISTA

Andrea Lapa - UFSC

Gilka Girardello - UFSC

O WHATSAPP COMO DISPOSITIVO PEDAGÓGICO PARA A CRIAÇÃO DE ECOSSISTEMAS EDUCOMUNICATIVOS

J. António Moreira - UAB-PT

Sara Dias Trindade - UC-PT

O USO DO WHATSAPP COMO PRÁTICA SOCIOINTERACIONISTA E ESPAÇO DE APROXIMAÇÃO ENTRE SURDOS E OUVINTES

Huber Kline Guedes Lobato - UFPA

Rubens Alexandre de Oliveira Faro - UFPA

Renata Moraes de Oliveira - UFPA 


\section{TEMA 2 - WHATSAPP E PROCESSOS EDUCATIVOS}

\section{5}

INTERAÇÓES NO CIBERESPAÇO: ESTUDOS E PESQUISAS SOBRE O WHATSAPP NA EDUCAÇÃO NO BRASIL E PORTUGAL

Ronaldo Nunes Linhares - UNIT

Alexandre Meneses Chagas - UNIT

Elbênia Marla Ramos Silva - Universidade de Aveiro - UA

EXPANSÃO E RECONFIGURAÇÓES DAS PRÁTICAS DE LEITURA E ESCRITA POR MEIO DO WHATSAPP

Cristiane de Magalhães Porto - UNIT

Kaio Eduardo de Jesus Oliveira - UNIT

André Luiz Alves - UNIT

MOBILIDADE, WHATSAPP E A APRENDIZAGEM:

REALIDADE OU ILUSÁO?

Lúcia Amante - UAB-PT

Lígia Fontana - UAB -PT

WHATSAPP COM FUNÇÃO STORIES:

ENSINAR E APRENDER NA MAGIA DO INSTANTE

Edvaldo Souza Couto - UFBA

Joana Dourado França de Souza - UFBA

WHATSAPP: CENÁRIO PARA DISCUSSÓES E REFLEXÓES SOBRE A PERMISSIVIDADE E LIMITE DA INTERAÇÃO DE CRIANÇAS

Lynn Alves - UNEB e Centro Universitário SENAI - CIMATEC

Velda Torres - UFBA e UCSAL 
CONVERSAS UBÍQUAS VIA WHATSAPP: AMBIÊNCIAS FORMATIVAS

MULTIRREFERENCIAIS

Rosemary Santos - UERJ

Felipe da Silva Ponte Carvalho - UERJ

Tânia Lúcia Maddalena - UERJ

\section{TEMA 3 - WHATSAPP, AUTORIA E PRÁTICA DOCENTE}

\section{5}

ENTRE PROCESSOS FORMATIVOS E INTERATIVOS:

O WHATSAPP COMO ESPAÇO SIGNIFICATIVO NA

ORIENTAÇÃO E FORMAÇÃO

Carloney Alves de Oliveira - UFAL

DIÁRIO ONLINE NO WHATSAPP: APP-LEARNING EM CONTEXTO DE PESQUISA-FORMAÇÃO NA CIBERCULTURA

Alexsandra Barbosa - UERJ

Edméa Santos - UERJ

Mayra Ribeiro - UERN

A WEB 2.0 E OS SOFTWARE SOCIAIS: OUTROS ESPAÇOSTEMPOS MULTIRREFERÊNCIAS DE FORMAÇÃO NA INICIAÇÃO

À DOCÊNCIA 257

Simone Lucena - UFS

Arlene Araújo Domingues Oliveira - UFS

Gilson Pereira dos Santos Júnior - UFS

CIÊNCIA COM LEVEZA: O WHATSAPP COMO ARTEFATO PEDAGÓGICO NA DISCIPLINA METODOLOGIA

DO TRABALHO CIENTÍFICO

Rosemary Lacerda Ramos - Unijorge 


\section{EDUCAÇÃO MEDIADA PELO WHATSAPP: ENSINAR E APRENDER POR MENSAGENS INSTANTÂNEAS}

[...] o professor escreve na lousa a lição que deveria ser copiada por seus estudantes, que, em vez disso, preferem fotografar a lousa. Aplicam, assim, as inovaçóes tecnológicas a seu favor para tentar minimizar o monótono esforço de copiar a lição e, desse modo, ganhar mais tempo livre para poder conversar, paquerar, zoar ou mesmo explorar algumas das múltiplas funçóes de seus smartphones. (Narrativa elaborada por Oliveira, 2017)

Além de transformar a capacidade de comunicação dos usuários, as tecnologias digitais e os aplicativos de troca de mensagens, por exemplo, possibilitam um deslocamento de açóes, uma vez que ação desenvolvida nem sempre é a esperada pelo mediador ou por outros usuários. No exemplo da narrativa, a ação esperada pelo professor seria que os alunos copiassem no caderno o conteúdo escrito à lousa pelo professor, mas por um deslocamento possível pela praticidade possibilitada a partir do uso dos dispositivos móveis a ação se resume a captura de uma foto de todo o conteúdo, para ter a possiblidade de fazer outras açóes.

Esta situação descreve um procedimento que é próprio dos processos cotidianos na cultura contemporânea. Uma vez que, as práticas culturais estão permeadas de artefatos digitais que não se resumem apenas as relaçóes comunicacionais, mas a consolidação de novos modos de aprender e de acessar informação, abrindo assim a necessidade de inovação também nos modos de ensinar. Uma simples ação pode existir por meio de elementos exteriores e se consolidar em novas perspectivas no caminho, mediante as tramas da rede e das práticas culturais da cultura vigente. 
Notamos na narrativa que associaçôes rotineiras entre alunos e artefatos culturais do seu tempo, os smartphones e os aplicativos, por exemplo, criaram a possibilidade de compor um cenário de inovação à ação natural que seria copiar o texto no caderno, como imaginava a professora. No entanto, a possibilidade de se associar a dispositivos e, consequentemente, a outras pessoas, desperta um tensão à própria metodologia escolhida pelo professor para o trabalho docente, provocando um desfecho inesperado.

Quando observamos este tipo de situação, podemos avaliar que o acesso à informação e ao conhecimento na cultura digital não se produz de forma isolada e estática, está intimamente ligado também aos processos comunicativos e infocomunicacionais disponíveis e até inesperados. Contudo é preciso discutir qual o impacto do uso destes dispositivos na consolidação das práticas educativas na atualidade. Qual a potencialidade destes artefatos na medicação do trabalho docente? Como podem ser associados às metodologias de ensino e as práticas de pesquisa? Posto que, as possibilidades educacionais e comunicativas que surgem na cultura contemporânea, articuladas às mudanças sociais e ao desenvolvimento e popularização das tecnologias digitais móveis, são constantes e expressivas, ao passo que novas potencialidades também podem gerar novos problemas.

Os sites de redes sociais digitais, os jogos on-line, os sites de compartilhamento de vídeo, os gadgets e os smartphones são agora os acessórios da cultura e, mais especialmente, dos jovens. Eles estão tão associadas à vida das pessoas que é difícil lembrar que estão a disposição apenas há poucos anos. Hoje, como também foi o caso de ontem por seus antecessores, os jovens atingem a idade da busca pela autonomia, mas na cultura digital eles fazem isso por maneiras diferentes, com outros modos de comunicação, outras formas de se relacionar, novas 
formas de jogar, novas formas de expressão e também de exposição.

Diante desse cenário, experiências de ensino e aprendizagem também são possíveis em variadas configurações. Em contrapartida, algumas tensóes da prática docente e dos processos educativos surgem e colocam em questionamento os modelos de ensino mais tradicionais que, enxergam com estranhamento os hábitos na cultura vigente. Alguns estudiosos da Cibercultura afirmam a esse respeito, de modo separatista que os jovens se configuram como nativos digitais da Cibercultura e os que nasceram antes dos anos de 1990, portanto, são imigrantes digitais.

Entretanto, avançar o limite da superficialidade nos faz perceber que embora os mais jovens sejam nativos digitais e configurem suas práticas cotidianas com artefatos culturais da Cibercultura, eles não têm fluência digital para sua autoaprendizagem, necessitando assim da figura do mediador. Deste modo, o papel do professor ou de algum mediador que articule a práticas culturais da Cibercultura para a promoção da aprendizagem sempre será eficaz e relevante.

A possibilidade de fotografar, armazenar ou até mesmo encaminhar o conteúdo para outra pessoa por meio de um aplicativo de redes sociais digitais na internet possibilitam a emissão e reconfiguração de novos conteúdos. Ainda que, não intencionais se tornam disponíveis ao uso e, naturalmente, contribuem para a produção ubíqua e colaborativa de novos conteúdos por meio da reconfiguração deles, mas essas práticas por si só não garantem a aprendizagem.

Ao passo que estamos cada vez mais conectados, mais associados aos ambientes on-line e com práticas culturais cada vez mais dependentes dos aplicativos e das tecnologias digitais e da internet, desenvolvemos modos de existência híbridos. $\mathrm{O}$ aplicativo WhatsApp Messenger, tem ganhado, cada vez mais 
destaque nesse cenário, pois a possibilidade de trocar mensagens, imagens, vídeos, documentos e áudios, instantaneamente de modo gratuito tem garantido novas experiências que não se resumem as performances comunicacionais.

$\mathrm{Na}$ Cibercultura uma boa parte dos indivíduos usam suas conexóes para encontrar a informação ou para explorar os seus centros de interesses que vão além do que eles têm acesso à escola ou o que eles encontram em sua comunidade local. Grupos on-line no WhatsApp, por exemplo, permitem aos jovens de se conectarem com colegas que partilham interesses comuns. Tencionam assim, a prática de outras habilidade inerentes ao dispositivo como a escrita e leitura, mesmo em linguagem digital pelo texto escrito, pela emissão de áudio e vídeos.

A popularidade do WhatsApp é incontestável, principalmente entre os mais jovens, pelo motivo das mensagens de voz e os vídeos terem se popularizada. Mas, a marca principal do aplicativo fica por conta de sua função principal que é enviar textos (escritos ou com os emojis) e gravaçóes de áudio que são pacotes de dados mais leves e que geram menos tráfego quando comprados aos vídeos.

Com vista as potencialidades do WhatApp na Cibercultura nas páginas que se seguem evidenciamos relatos de experiências e práticas pedagógicas. Estes são resultados de pesquisa e formação construídas por meio de inquietaçóes de investigadores de grupos de pesquisas distintos e instituiçóes diversas. Assim, apresentamos este livro que tem como principal objetivo discutir a utilização do aplicativo WhatsApp como espaço de ensino, aprendizagem e formação, na Cibercultura.

Oferecemos ao leitor mais possibilidades para fazer um estudo diverso e amplo, que tem no aplicativo seu objeto de estudo e discussão e um espaço de tensão. Nas páginas as seguir apresentaremos experiências de pesquisadores, propostas de ensino e apren- 
dizagem, outras formas de ensinar e aprender que tem o WhatsApp como mediador do processo. Para que o leitor se localize com mais facilidade e, também, por julgarmos importante a divisão por temas, este livro composto com trabalho de autores do Brasil e de outros países, divide-se em três grande eixos nos quais se encontram ordenados do seguinte modo:

O primeiro tema está intitulado como "WhatsApp, Mediação e Processos Comunicativos", onde concentramos os trabalhos que se propóe a discutir o WhatsApp a partir da perspectiva comunicacional. Assim, apresentam-se experiências de como aplicativo de rede social pode mediar conexóes entre diferentes agentes em espaço-tempo distintos com um objetivo em comum, que avançam o limite do uso social.

No segundo tema estão dispostos os arquivos que se centram na temática "WhatsApp e Processos Educativos", onde reunimos os textos que apresentam o aplicativo como mediador dos processos de ensino e aprendizagem, seja na educação, formal, informal ou não-formal e que possibilitam a consolidação de novas experiências educativas.

O terceiro e último tema denominado "WhatsApp, Autoria e Prática Docente", agrupa trabalhos que discutem o WhatsApp mediante suas possiblidades de desenvolver pesquisas e auxiliar na prática docente mediante a articulação com as metodologias de ensino ou os desenhos didáticos e curriculares de cada professor.

Apesar de estarem agrupados por temáticos, é importante destacar que os trabalhos deste livro não seguem uma ordem linear. Deste modo, esperamos que os textos aqui apresentados, mesmo que lidos de modo disperso, possam contribuir ou auxiliar novas práticas de pesquisa e formação na Cibercultura e instigar também novas propostas de ensino e aprendizagem.

Acreditamos que o conjunto textual aqui delineado com seus objetivos e argumentos trazem um contributo significati- 
vo para repensarmos e inovarmos o uso do WhatsApp na educação. Seja este uso em uma proposta de educação formal ou por meio de processos formativos vinculados à educação que se constrói e se passa nos mais variados espaços sociais. O fenômeno da utilização de aplicativos que discutimos em tela por meio dos processos de comunicação em rede, nos oferece rastros suficientes para que este seja aplicado nos mais diversos e múltiplos contextos educativos, objetivando náo apenas uma inovação, mas, também, revisitando cada finalidade que este nos oferece.

Cristiane Porto

Kaio Eduardo Oliveira Alexandre Chagas

(Organizadores) 


\section{PREFÁCIO}

\section{Paulo Freire, Vygotsky, Freinet, Dewey e Anísio Teixeira usariam o WhatsApp!}

Marco Silva

Costumo dizer: se estivessem vivos hoje e fossem incluídos ciberculturais, Paulo Freire, Vygotsky, Freinet, Dewey e Anísio Teixeira saberiam tomar a Web 2.0 ou a internet social e suas redes sociais como aliados capazes de materializar a açáo comunicacional da educaçáo autêntica, presencial e online, feita de conectividade, autoria, compartilhamento, colaboração, dialogia e interatividade.

Sim! Essas referências internacionais em educação realizaram suas docências e pesquisas acadêmicas no cenário midiático de que dispunham - imprensa, rádio e TV -, em que prevaleceu o paradigma unidirecional determinando a interaçáo emissor-receptor. Porém, em seus livros, concebem a pedagogia como prática potencializadora da autonomia, diversidade, interaçáo, dialógica e democracia em sala de aula. Essa percepçáo da educaçáo coexistiu desconfortável com o modus operandi das tecnologias de informação que eles conheceram, ainda que tenham lançado máo delas para divulgação de conteúdos e promover estratégias de aprendizagem como assistir a um filme, ler um texto e ouvir um áudio.

Se estivessem vivos e atentos ao cenário comunicacional da cibercultura ou da cultura digital, Freire, Vygotsky, Freinet, Dewey e Teixeira se sentiriam muito à vontade para fazer uso do smartphone, do tablet e do laptop como aliados em sala de aula. Saberiam

1 Sociólogo, doutor em Educação, professor da Faculdade de Educação da Universidade do Estado do Rio de Janeiro (UERJ) e autor do livro Sala de aula interativa.

E-mail: mparangole@gmail.com 
explorar suas telas não meramente como planos de transmissão para assistir a filme, ler texto e ouvir áudio, mas como ambientes de imersão, manipulação e interlocução, com janelas, ícones e aplicativos móveis abertos a múltiplas conexôes, que permitem intervençóes e modificações autorais e colaborativas nos conteúdos e na comunicação.

Se estivessem vivos e atentos ao nosso cenário midiático, perceberiam que o aprendiz migra da condição de espectador com um controle remoto nas máos para a de participador que opera naturalmente com a tela tátil, imersiva, em rede conversacional, que lhe permite adentramento, autoria, colaboração e o gesto instaurador que cria e alimenta sua experiência comunicacional.

Se fossem usuários das redes digitais, dos blogs, dos wikis, veriam que o tripé fundamental da comunicação passa por uma modificação radical favorável a suas concepções de educação, quando a mensagem muda de natureza, o emissor muda de papel e o receptor muda de status.

- $\mathrm{O}$ emissor não emite mais, no sentido que se entende habitualmente, uma mensagem fechada. Ele oferece um leque de elementos e possibilidades à manipulação do receptor.

- A mensagem não é mais "emitida", não é mais um mundo fechado, paralisado, imutável, intocável, sagrado. É um mundo aberto, modificável, na medida em que responde às solicitaçôes daquele que a consulta.

- O receptor não está mais em posição de recepção clássica. Ele é convidado à livre autoria colaborativa. A mensagem ganha sentido sob sua intervenção.

Se estivessem vivos e atentos ao espírito do nosso tempo, Freire, Vygotsky, Freinet, Dewey e Teixeira muito provavelmente adotariam o WhatsApp, que contempla a participação de sujeitos dialogantes na dinâmica da autoria e da cocriação da comunicação, da aprendizagem e da formação. Esse aplicativo favorece a docência e a aprendizagem em sala de aula presencial e online porque permi- 
te reunir interlocutores em bidirecionalidade, multidirecionalidade, comunicação síncrona e assíncrona, com troca de texto, áudio, imagem e vídeo, documentos em PDF e ligaçôes gratuitas por meio de conexão com a internet.

Por sua vez, a docência ciberincluída e inspirada no legado dos mestres citados saberia intuitivamente lançar máo do WhatsApp para promover a extensão da sala de aula presencial no ciberespaço e aí mobilizar a autêntica educação cidadá. Entretanto, ainda que intuitiva, a utilização desse aplicativo não deixaria de lançar mão das contribuiçôes reunidas na coletânea intitulada WhatsApp e educação: entre mensagens, imagens e sons, organizada por Cristiane Porto, Kaio Eduardo Oliveira e Alexandre Chagas. Esse volume reúne trabalhos de pesquisadores antenados com a cibercultura ou com a cultura digital e com a tradição crítica ou emancipatória da educação e trata de inúmeras funcionalidades, vantagens e possibilidades pedagógicas do WhatsApp. Os textos estão organizados em três segmentos: 1) What$s A p p$, mediação e processos comunicativos; 2) WhatsApp e processos educativos; e 3) WhatsApp, autoria e prática docente.

\section{WhatsApp, mediaçáo e processos comunicativos}

Dá início ao primeiro segmento desta coletânea o texto "Gestão em rede na primavera secundarista", das autoras Andrea Lapa e Gilka Girardello. Seu objeto é a análise de uma experiência pedagógica que articulou uma disciplina de pós-graduação em uma universidade federal e as ocupaçóes de escolas por estudantes em defesa da educação durante a chamada "Primavera Secundarista" de 2016. O trabalho baseia-se nos referenciais das teorias da comunicação, dos estudos culturais e da mídia-educação, bem como nos conceitos-eixo do programa Cultura Viva do Ministério da Cultura (MinC): autonomia, protagonismo, empoderamento e gestão em rede. Como o foco da disciplina eram as relaçôes entre educação, cultura digital e culturas populares no contexto brasileiro contemporâneo, a emergência das 
lutas estudantis levou a turma a constituir-se como um coletivo solidário que passou a apoiar diretamente os movimentos protagonizados pelos secundaristas. Um dos espaços comunicativos mais utilizados nessa experiência, tanto para comunicação interna quanto para comunicação externa, foi o aplicativo WhatsApp Messenger. Cada estudante fazia a ponte dos acontecimentos e contatos de sua própria rede dentro das escolas ocupadas com os outros estudantes e as professoras da turma. Para tal, foi criado o grupo EcoAçâo, que acolheu todas as trocas discursivas do grupo, em texto, áudio e vídeo, fonte preciosa de dados que permitiu analisar a experiência midiático-educativa da disciplina e essas novas formas de comunicação contemporâneas como espaços de formação da cultura digital. Na análise do processo, o texto identifica contribuiçóes para a reflexão no campo educacional, especialmente diante da persistência de uma distância entre a universidade e as escolas, e do risco de que a proposta de educar com, para e através das mídias possa às vezes reduzir-se à retórica. Em suma, o texto discute aspectos favoráveis à invenção pedagógica no campo da Educação e da Comunicação.

O segundo texto da primeira seção, de autoria de J. António Moreira e Sara Dias Trindade, tem como título "O WhatsApp como dispositivo pedagógico para a criação de ecossistemas educomunicativos". Reflete sobre a aplicabilidade pedagógica do Whats App procurando analisar possibilidades e potencialidades desse dispositivo na criação e desenvolvimento de ecossistemas digitais comunicativos em diferentes níveis de ensino. Seus autores estáo duplamente atentos: 1) para a potência do aplicativo capaz de proporcionar aos docentes e estudantes oportunidades de aprendizagem desenhadas “à medida” e passíveis de serem concretizadas em praticamente qualquer lugar e a qualquer hora; 2) ao mesmo tempo, para a mudança de paradigma educativo revelando cada vez mais tênue a linha que separa a educação formal da informal e não formal, bem como a necessidade de urgente 
otimização das potencialidades do denominado "software social". Com base nessa dupla atençáo, o texto trata de potencialidades do WhatsApp para o desenvolvimento de estratégias de aprendizagem motivadoras para a aquisição de competências pelos estudantes, cada vez mais imersos no mundo digital.

O último texto do primeiro segmento dedicado a mediaçáo e processos comunicativos tem como título "O uso do WhatsApp como prática sociointeracionista e espaço de aproximação entre surdos e ouvintes". Seus autores, Huber Kline Guedes Lobato, Rubens Alexandre de Oliveira Faro e Renata Moraes de Oliveira, partem das seguintes questóes: a) de que forma o aplicativo Whats $A p p$ contribui na interação entre surdos e ouvintes?; b) quais as percepçóes de participantes de um grupo do WhatsApp sobre a interação entre surdos e ouvintes?; c) quais as contribuiçôes do aplicativo para aproximar o mundo de surdos ao mundo de ouvintes? Com base nessas questóes específicas, eles dão conta do objetivo principal do texto, que é analisar a contribuição do WhatsApp para a interação entre surdos e ouvintes. Para dar conta desse desafio, trabalham com: a) preceitos sociointeracionistas segundo a perspectiva vygotskiana; b) percepçóes de participantes de um grupo do WhatsApp sobre a interação entre surdos e ouvintes; e c) análise das contribuiçóes do aplicativo WhatsApp para aproximar o mundo de surdos ao mundo de ouvintes. Os resultados do estudo apresentado no texto revelam que: a) o Whats $A p p$ contribui na interação entre surdos e ouvintes; b) os participantes partilham informaçóes e conhecimentos por meio do aplicativo; e c) o uso do Whats $A p p$ propicia, de forma equânime, condiçóes de interação entre surdos e ouvintes. Em suma, o texto revela que o uso do aplicativo, como prática sociointeracionista, é um espaço de aproximação entre surdos e ouvintes que contribui com o uso e difusão da Língua Brasileira de Sinais (Libras) e da Língua Portuguesa em sua modalidade escrita, seja por meio de chamadas de vídeos ou por mensagens de textos. 


\section{WhatsApp e processos educativos}

Dedicada a processos educativos, a segunda seção do livro tem como primeiro texto "Interaçôes no ciberespaço: estudos e pesquisas sobre o WhatsApp na educação no Brasil e em Portugal”. Seus autores, Ronaldo Nunes Linhares, Alexandre Meneses Chagas e Elbênia Marla Ramos Silva, mapeiam e analisam a produção científica sobre o uso do WhatsApp como plataforma de comunicação e educação no processo de aprendizagem. Para revelar o que está sendo feito e em que estágio se encontram os estudos e pesquisas sobre esse tema, optaram por: a) quantificar e mapear os dados sobre dissertaçóes e teses que tenham como objeto o WhatsApp/educação no Brasil e Portugal, de 2009 até 2017; b) identificar nessa produção as tendências teórico-metodológicas, autorias e resultados, procurando responder às seguintes questóes: quando, onde, quem, o quê, com que objetivo, como e quais os resultados; e c) comparar a produção dos dois países procurando estabelecer aproximaçóes e distanciamentos na busca de compreender a relevância e contribuição do WhatsApp no processo de aprendizagem. Atentos ao desafio de mapear essa produção ainda em construção, considerando a novidade e inovação do objeto no campo da educação, os autores têm consciência de que lidam com as marcas iniciais do WhatsApp no território da cibercultura e no campo da educação.

O texto de Cristiane de Magalhães Porto, Kaio Eduardo de Jesus Oliveira e André Luiz Alves, intitulado "Expansão e reconfiguraçôes das práticas de leitura e escrita por meio do WhatsApp", discute as reconfiguraçóes das habilidades e práticas de leitura e escrita no aplicativo WhatsApp Messenger. A partir de pesquisa bibliográfica, defende o argumento de que o aplicativo: a) tem favorecido processos comunicativos "mais interativos" por meio da troca de mensagens instantâneas; e b) tem possibilitado novas práticas de leitura e de escrita cotidianas, mediante a convergência de elementos próprios do aplicativo, do hipertexto e da cultura digital, tais como: emojis, emotions, imagens, áudios e vídeos, que passam 
a integrar as práticas de leitura e escrita, atualizando a concepção clássica de letramento.

Lúcia Amante e Lígia Fontana são autoras do texto "WhatsApp e a aprendizagem: realidade ou ilusão?". Considerando que a adoção de plataformas e ferramentas digitais pode contribuir significativamente para o desenvolvimento de habilidades e competências compatíveis com as novas demandas sociais que se colocam à aprendizagem no ensino superior, elas discutem no texto a utilizaçáo do WhatsApp como aplicativo que promove a aprendizagem colaborativa e ubíqua, permitindo aos estudantes construir um percurso próprio de aprendizagem. Ademais procuram identificar os tipos de funçóes que, no processo de aprendizagem, os estudantes atribuem a esse aplicativo, bem como entender as limitaçóes do WhatsApp, tendo por base uma experiência de utilização desenvolvida com um grupo de estudantes de educação em contexto universitário.

O texto "WhatsApp com função Stories: ensinar e aprender na magia do instante", de Edvaldo Souza Couto e Joana Dourado França de Souza, chama especial atenção para a função Stories, uma novidade incorporada ao aplicativo que permite o compartilhamento de fotos e vídeos por tempo determinado. A função Stories, já conhecida no SnapChat, outro aplicativo de rede social, surpreende porque difere de outras redes sociais em que as mensagens eram destinadas ao registro eterno. $\mathrm{Na}$ função Stories, cada publicação é condenada a desaparecer em pouco tempo. O texto chama a atenção para a promoção do esquecimento por meio de mensagens autodestrutivas e problematiza a adoção e recorrência dessa função em várias redes sociais. Alerta para a dissolução de características específicas da participação nas redes sociais e para o risco de padronização dos ambientes antes marcados por experiências ricas que ressaltavam a diversidade de mecanismos. A partir de estudos sobre a cibercultura e as redes sociais digitais no âmbito da educação, apresenta resultados de uma pesquisa qualitativa com um grupo de professores que relata possibilidades pedagógicas do 
WhatsApp com a função Stories. São discutidos os significados do ensinar a aprender, lembrar e esquecer, registrar e apagar conteúdos na magia do instante em nossas comunicaçóes ubíquas.

"WhatsApp: cenário para discussóes e reflexôes sobre a permissividade e limite da interação de crianças e adolescentes com o universo digital" é o texto assinado por Lynn Alves e Velda Torres. Seu foco é a reação dos pais à adesão da juventude aos artefatos sociotécnicos contemporâneos que vêm provocando mudanças na forma como as pessoas se organizam, acessam informaçóes e produzem conhecimentos, a exemplo dos telefones móveis que se converteram em computadores na palma da máo, possibilitando acesso a arquivos armazenados nas nuvens computacionais, gerenciamento de e-mails e processos comunicacionais. Alguns pais têm estabelecido limites para interação dos filhos com o universo digital, inclusive pais pesquisadores da cultura digital. $\mathrm{O}$ texto aborda as angústias desses pais em torno do seu papel diante do desejo de interação frequente dos filhos com as tecnologias digitais. As angústias foram registradas nas discussões em um grupo no Whats $A p p$ com membros do Centro de Pesquisa e Desenvolvimento Comunidades Virtuais - CV - Uneb. O texto analisa essas angústias e apresenta o WhatsApp como espaço para reflexão e formação de professores e pesquisadores.

O texto "Conversas ubíquas via Whatsapp: ambiências formativas multirreferenciais", de Rosemary Santos, Felipe Carvalho e Tânia Lúcia Magdalena, resulta de pesquisa que investigou a aproximação do currículo universitário das práticas cotidianas da cibercultura, arquitetando e planejando ambiências formativas emergentes de práticas colaborativas, autorais e abertas. $\mathrm{O}$ estudo desenvolveu-se com os cotidianos de cursistas e um docente-pesquisador na disciplina Informática na Educação, do curso de licenciatura em Pedagogia, Uerj/Cederj/UAB, oferecida em 12 polos localizados em municípios do Estado do Rio de Janeiro em 2014. As conversas do WhatsApp tomadas como dispositivos de pesquisa revelaram possibilidades de 
maior interação entre subjetividades próprias dos praticantes pesquisados. Com base nessa investigação, o texto aborda as práticas que acontecem cotidianamente com os usos dos dispositivos móveis, nos deslocamentos de espaços e tempos, em que as pessoas têm dinamizado a produção de enunciados sobre lugares e acontecimentos, expressando diferentes perspectivas sobre o mundo.

\section{WhatsApp, autoria e prática docente}

O texto de Carloney Alves de Oliveira "Entre processos formativos e interativos: o WhatsApp como espaço significativo na orientação e formação " abre o último segmento deste livro. Ele registra os resultados de pesquisa que investigou as contribuiçóes e as potencialidades do WhatsApp nos processos de orientação e formação de bolsistas do Programa Institucional de Bolsas de Iniciação Científica (Pibic) na Universidade Federal de Alagoas (UFAL). E reflete sobre a formaçáo do pedagogo em face do WhatsApp e atento às interaçóes entre os sujeitos envolvidos através de estratégias didáticas. Revela também o desejo por uma melhor prática na utilização do WhatsApp constatado no seu universo de pesquisa, formado por dois orientandos do Pibic, alunos do Curso de Licenciatura em Pedagogia da Ufal, à disposição para um acompanhamento sistemático e uma formação adequada, com apoio, diálogo e colaboração. Atesta também que o WhatsApp permite a configuração de novas maneiras de aprender e orientar pela interação e exploração do aplicativo - na experimentação e na colaboração -, inserindo os sujeitos e proporcionando espaços para reflexóes sobre o processo formativo na cultura digital.

"Diário online no WhatsApp: app-learning em contexto de pesquisa-formação na cibercultura" é o texto de Alexsandra Barbosa, Edméa Santos e Mayra Ribeiro. Parte do entendimento de que a cultura contemporânea tem proporcionado diferentes usos das tecnologias móveis no âmbito da educação, tais como a utilização de celulares, smartphones e tablets na pesquisa e na formação 
de professores. E confirma que os aplicativos ensejam situações de aprendizagem nas quais os sujeitos interagem e aprendem em mobilidade e ubiquidade, possibilitando, assim, novos modos de produção de saberes. Ao articular tecnologias e aplicativos com a "pesquisa-formação na cibercultura", as autoras do texto revelam sua abordagem sobre o app-learning, modo como denominamos "saberesfazeres" provenientes do uso de aplicativos nos processos de "aprendizagemensino". O texto revela que os aplicativos podem ser utilizados nas pesquisas como dispositivos que registram, através da escrita, da fotografia, de áudios e de vídeos, o que é vivenciado. Ao mesmo tempo, reflete sobre o uso do WhatsApp Messenger como diário online no processo formativo de uma pesquisa-formação na cibercultura no contexto do Grupo de Pesquisa, Docência e Cibercultura (GPDOC).

O texto "A web 2.0 e os software sociais: outros espaços tempos multirreferencias na iniciação à docência" nasceu do esforço de compreender e explorar as potencialidades dos recursos presentes nas tecnologias móveis utilizadas no Programa Institucional de Bolsa de Iniciação à Docência (Pibid) da Universidade Federal de Sergipe, com os bolsistas de iniciação à docência e com supervisoras das escolas vinculadas ao Pibid/Pedagogia. Os autores, Simone Lucena, Arlene Araújo Domingues Oliveira e Gilson Pereira dos Santos Junior, realizaram a pesquisa durante a formação no Pibid utilizando o WhatsApp Messenger. Como resultado, observaram que os grupos criados com os sujeitos da pesquisa passaram a utilizar esse aplicativo como outro espaçotempo de formação. De acordo com os autores, o aplicativo permite a criação de um espaço multirreferencial com possibilidades de socializar, interagir e narrar instantaneamente todas as açóes desenvolvidas nos diferentes ambientes de aprendizagem. Simone, Arlene e Gilson sugerem ainda que os softwares sociais potencializam a criatividade e a colaboração entre seus usuários, favorecem a divulgação de suas autorias em forma de texto, áudio, imagem e vídeo. 
Para finalizar o texto de Rosemary Lacerda Ramos "Ciência com leveza: o WhatsApp como artefato pedagógico na disciplina metodologia do trabalho científico". O texto resulta de investigação sobre as potencialidades didáticas do WhatsApp como artefato de comunicação e mediação didático-pedagógica no percurso da disciplina Metodologia Científica. O WhatsApp foi escolhido por ser um dos mais populares aplicativos de mensagem multiplataforma com relevante potencial comunicacional. Por sua vez, a delimitação da disciplina Metodologia Científica como locus da experiência se justifica por ser fundamental no desenvolvimento de produçóes científicas dos estudantes que ingressam no ensino superior e ao longo do curso são estimulados a desenvolver trabalhos científicos como parte dos requisitos de avaliação, além de contribuir com o letramento acadêmico e iniciação à prática de pesquisa com suas diversas circunstâncias de natureza técnica e estética. A "pesquisa-ação” realizada com seis turmas de pós-graduação adotou o WhatsApp como artefato mediador do processo ensino-aprendizagem na referida disciplina. Os resultados revelaram uma grande aceitação, maior interação entre os pares, engajamento e motivaçáo para o estudo, contribuição com a construção coletiva do conhecimento, participação e colaboração dos discentes no processo de ensino e aprendizagem para além dos limites físicos da sala de aula com intensificação da sua participação nas atividades didáticas.

Em 2017, ano de publicação desta coletânea, o WhatsApp completa oito anos como software de autoria, compartilhamento, conectividade e colaboração mais popular no Brasil. Se ainda estivessem entre nós e pudessem ler os textos aqui reunidos, Freire, Vygotsky, Freinet, Dewey e Teixeira concordariam que o cenário sociotécnico da internet social está em sintonia paradigmática com o que os reúne em favor da educação cidadá: autonomia, diversidade, interação, dialógica e democracia. Temos a confluência de uma tradição pedagógica transtemporal 
forjada no cenário analógico desfavorável e a atualidade digital pujante com forte adesão social. Essa confluência é histórica e nos faz ver que temos uma situação de vantagem quando estão disponíveis as condiçôes de fazer algo em favor da formação de professores e da educação em nosso tempo. 


\section{TEMA 1 \\ WHATSAPP, MEDIAÇÃO E PROCESSOS COMUNICATIVOS}




\title{
GESTÁO EM REDE NA PRIMAVERA SECUNDARISTA
}

\author{
Andrea Lapa - UFSC \\ Gilka Girardello - UFSC
}

Rede. Nós construimos juntos uma rede com barbante. De repente tínhamos uma Teia pronta. (BRASIL, 2009, p. 70)

\section{Introdução}

O ano de 2016 foi marcado por acirradas disputas políticas no cenário nacional. Um golpe à democracia que culminou com o fortalecimento do neoliberalismo como lógica da governança e perdas sucessivas de direitos conquistados. As pessoas, expostas a um bombardeio diário de notícias tendenciosas e ao fogo cruzado na polarização das redes sociais, tiveram dificuldade para operar o distanciamento reflexivo e a leitura crítica da realidade. Contudo, houve resistência. E em nenhum outro lugar social ela tomou pé com tanta firmeza como na escola.

Em outubro de 2016, estudantes ocuparam novamente escolas públicas de ensino fundamental e médio por todo o Brasil, incluindo universidades públicas e particulares. $\mathrm{O}$ alvo do protesto eram duas grandes reformas propostas pelo novo governo: a medida provisória MP 746, que propunha a reforma do ensino médio e a PEC 241/PEC 51, que propunha o congelamento dos gastos públicos por 20 anos, atingindo em cheio os investimentos em educação. 
Não se pode minimizar aqui o papel das mídias. Se por um lado temos uma nova base tecnológica de comunicação e interação, há também uma reconfiguração da indústria cultural que propicia a participação de sujeitos como consumidores entretidos e não cidadãos. A internet apresentou desde sempre um potencial de promover a liberdade e a desestabilização de relaçóes de poder instituídas. Mas a realização deste potencial depende de contexto e processo, como diz Castells (2013), pois ele precisa ser descoberto por experiência e não proclamado de antemão. Isto implica que difundir o uso de TIC sem alterar o contexto pode tornar a sociedade mais suscetível a intensificar suas tendências contraditórias já presentes.

A esperança está em que nossa prática tanto é afetada pela internet como a nossa diversidade de apropriação a altera. Por essa razão reconhecemos as interaçóes humanas nas redes sociais como um espaço potencial para a realização da promessa de apropriação crítica e criativa das tecnologias. Estes novos espaços públicos presentes no ciberespaço (aplicativos como: Facebook, Twitter, Whatsapp Messenger, Instagram, entre outros) acolhem a sociabilidade contemporânea e são espaços de expressão da organização social.

Destacamos que a interação de indivíduos nas redes sociais pode formar comunidades, mas não necessariamente. No ciberespaço, as pessoas se relacionam, trocam informaçóes e recursos, mas também constituem redes de laços interpessoais que proporcionam sociabilidade, apoio, integração e identidade social. Quando criam vínculos de alguma ordem e constroem algo em comum, elas formam comunidades tão intensas como as presenciais (WELLMAN; GULIA, 1999).

Por muito tempo se defendeu que o ciberespaço redefinia a noção de comunidade. Como não eram mais culturalmente homogêneas ou espacialmente limitadas, formavam-se como comunidades de escolhas, com mais ênfase ao papel de apoio aos indivíduos do que ao seu componente cultural. Porém, o atual ativismo digital evidenciou um espaço público híbrido, mescla de ciberespaço e espa- 
ço urbano, "constituindo, tecnológica e culturalmente, comunidades instantâneas de prática transformadora” (CASTELLS, 2013, p. 16).

Há diferenças qualitativas nos diversos espaços da internet. Por exemplo, o Twitter denota um uso mais público do que Facebook e Instagram, porque a participação ali se dá por indivíduos (@-perfis) que se conectam em torno de um tema (\#-hashtags) e não apenas em torno de pessoas. A configuração do Facebook é um pouco diferente, favorecendo a polarização, o fechamento de grupos em bolhas de autoreferência que criam a ideia de um mundo de discurso único e de um indivíduo padronizado. Apesar de o Facebook permitir mais espaço para exposição de conteúdos (o Twitter se limita a 140 caracteres, o Instagram a imagens), a interação não se dá a partir de temas de interesse, mas de vínculos particulares. E a participação dos indivíduos se restringe geralmente a curtir e compartilhar, isto é, reforçar pontos de vista prévios, mais do que se abrir à construção de sentidos comuns.

Por sua vez, o WhatsApp Messenger aproxima grupos já formados, criando um espaço de trocas instantâneas e privadas que amplificam as possibilidades de interação, à revelia de condiçôes espaciais e temporais. Como um espaço mais reservado e protegido, tem sido usado amplamente para aproximar pessoas em uma comunicação rápida, barata e ao alcance das mãos. Na educação, tem propiciado a quebra dos "muros" da escola, tanto levando o mundo exterior para dentro da sala de aula, como conectando estudantes e professores fora do tempo e espaço escolares.

Uma extensiva revisão de literatura foi sistematizada por Arun Gupta (2014) sobre redes sociais na educação superior aparecendo como algumas de suas principais implicaçóes: a promoção da cultura participativa, da expressão de opiniôes em um fórum mais amplo e de uma gestão mais transparente do coletivo; o aumento da motivação e a intensificação de diálogos reflexivos e de conexóes interpessoais (GUPTA, 2014, p. 242-243).

Este levantamento aponta também desafios, entre eles o tempo gasto em atividades não acadêmicas, a distração, as questóes de 
segurança e privacidade e a ambiguidade em relação ao caráter da rede como sendo espaço privado ou público (aqui se referindo mais ao Twitter e ao Facebook). Especificamente em relação ao What$s$ App na educação brasileira, a revisão feita por Bottentuit Jr, Albuquerque e Coutinho (2016, p. 81) observou que o aplicativo tem sido usado como "ambiente para a realização de cursos e formação, para a discussão de temas relacionados às disciplinas curriculares, ou mesmo como estratégia para a resolução de tarefas, problemas, e esclarecimento de dúvidas".

Para identificar formas de apropriação crítica e criativa de TIC em um uso emancipador, trazemos à luz nesse artigo uma experiência de uso do WhatsApp Messenger na educação, onde um grupo da pós-graduação usou esta mídia para apoio, informação e articulação com vistas à pesquisa e à ação coletiva em um contexto político de mobilização a favor da educação. Salientamos nessa experiência uma característica para além das anteriores: a articulação entre a rede estabelecida a partir da sala de aula, na universidade, com as redes de ativistas, principalmente estudantes secundaristas nas escolas ocupadas, num intenso processo cultural favorecido pelo compartilhamento de mensagens via aplicativo.

Conhecer em maior profundidade este espaço de possibilidade a partir de usos inovadores pode trazer uma chave importante para a compreensão do fenômeno que tem nos instigado na atualidade: o papel das mídias digitais, em especial as redes sociais, na formação de sujeitos mais autônomos, empoderados, comprometidos com as transformaçóes sociais de seu contexto.

\section{Uma vivência inspiradora: a oferta da disciplina}

A oportunidade de uma vivência singular com as redes sociais on-line surgiu na disciplina de pós-graduação Educação Comunicação e Cultura, oferecida no segundo semestre de 2016 na Universidade Federal de Santa Catarina. Tínhamos como objetivo 
refletir sobre as relaçóes entre Educação e Cultura no contexto comunicacional contemporâneo com 20 estudantes de mestrado e doutorado. Tratava-se de compreender a escola e a produção do conhecimento em sua relação com a cultura popular (saberes, tradição, memória) e a cultura digital (em/nas redes) por meio da articulação entre arte, linguagens e pesquisa a partir da perspectiva da mídia-educação.

Após uma introdução onde apresentamos concepçóes de diferentes autores sobre os conceitos de educação, comunicação e cultura, revisitamos as teorias da comunicação para compreender o papel das mídias na sociedade contemporânea. A seguir, refletimos sobre as condiçóes possíveis para a criaçáo de espaços educativos de resistência com foco na cultura (WILLIAMS, 2001), com ênfase na formação de sujeitos pela práxis (FREIRE, 1998) e na necessidade de estarmos "nas intersecçóes, nos lugares em que os sujeitos podem falar e atuar, transformar-se e ser transformados" (GARCÍA CANCLINI, 2009, p. 208). Trouxemos também para o grupo uma proposta de mídia-educação, incluindo as dimensôes da produção, da linguagem, da representação e da audiência, tanto na criação como na crítica (BUCKINGHAM, 2005).

A proposta metodológica da disciplina acompanhou seu conteúdo teórico, fomentando a experiência em busca de alternativas, por meio da desestabilização do constituído e do fomento à ação (MARTÍN-BARBERO, 2009). O autor já alertava que há uma grande distância entre defender o novo paradigma educativo e de fato assumir os desafios concretos que ele impóe à docência: formar cidadãos autônomos, que fazem uma leitura crítica do mundo em que vivem e se sentem empoderados para buscar alternativas a ele, que assumem o protagonismo na sociedade, agindo efetivamente em rede pela sua transformação.

Para tratar esses conceitos de maneira transversal na disciplina, propusemos um estudo do documento Novos Mapas Conceituais do Programa Cultura Viva (BRASIL, 2009) e que cada dupla de 
alunos apresentasse, no início de cada aula, uma provocação ligada aos temas da disciplina: um vídeo, um texto literário, uma performance. Nos inspirava a sugestão de "abrir espaço para o 'pessoal' - para que estudantes (e professoras) compartilhem suas interpretaçôes, sentimentos e respostas subjetivas, descrevendo e refletindo sobre suas experiências cotidianas com as mídias [e culturas] fora da sala de aula" (BUCKINGHAM, 2005, p. 121).

\section{Novos mapas conceituais}

O trabalho principal da disciplina seria, então, uma articulação teórico-prática a partir dos quatro eixos conceituais - empoderamento, protagonismo, autonomia e gestão em rede - estruturados nos Novos Mapas Conceituais do projeto Cultura Viva (BRASIL, 2009). Esse documento foi criado coletivamente a partir de um seminário realizado em Pirenópolis em 2009, por intelectuais, artistas e agentes culturais de todo o país e do exterior envolvidos entre 2004 e 2009 com a rede de Pontos de Cultura impulsionada pelo Ministério da Cultura.

Este documento sistematiza conclusóes e desafios da rede nacional de Pontos de Cultura, sendo atravessado por preocupaçóes teóricas, pedagógicas e comunicativas que conversam com propostas que são referência em nosso campo, como o dialogismo, a participação, a horizontalidade. Nosso recurso a ele buscou ser um gesto de resistência político-cultural diante do presente enfraquecimento institucional do MinC.

Este debate, enraizado nas práticas locais de mais de 2.500 pontos de cultura e na multiplicidade de saberes que envolvia tanto intelectuais como Boaventura Santos, quanto mestres tradicionais como Mãe Lúcia de Oyá T’Ogum, era essencial em uma disciplina em que a noção de Williams de que "A cultura é de todos" (2001) era uma referência. Ainda sob o risco de perder a riqueza da multiplicidade de vozes e a polissemia enunciadas no documento ori- 
ginal, os sintetizamos a seguir, salientando que eles estão articulados entre si e que, em todos os casos, o sujeito desses conceitos é sempre coletivo: uma comunidade, um grupo de artistas ou educadores locais.

Assim, a autonomia surge como "a capacidade de governar-se pelos próprios meios" (BRASIL, 2009, p. 36), "de agir coletivamente e de conseguir encontrar, dentro da própria comunidade ou em outros parceiros" (BRASIL, 2009, p. 57), os recursos necessários para alcançar seus objetivos. Sua sustentação é "a identidade ou o sentimento de pertença, além do compartilhamento de valores entre um determinado grupo de atores" (BRASIL, 2009, p. 57).

$\mathrm{O}$ protagonismo surge associado a processos de resistência, iniciativa e responsabilização pelos interesses do coletivo, "em que os obstáculos vão sendo interpretados como desvios e não necessariamente como barreiras que impedem a ação". Nas palavras de um participante: "Protagonismo é buscar solucionar os problemas de outras formas. [...] vamos imaginar o futuro, depois a gente pensa nos recursos. Aí a própria comunidade descobre que todos os recursos de que ela necessita já estavam ali” (BRASIL, 2009, p. 57).

Já o conceito de empoderamento é definido como um fortalecimento conjunto, "um processo de reconhecimento de demandas coletivas e de construção de um sentimento de pertença mais amplo que permite [aos] atores disputar diversos espaços, alcançar representatividade política e visibilidade pública” (BRASIL, 2009, p. 57). Quanto ao conceito de gestão em rede, refere-se no documento a "processos de autogestáo e corresponsabilidade, diluindo-se o poder em vários pontos focais, [...] onde as ações são construídas coletivamente"(BRASIL, 2009, p. 57).

\section{A turma no contexto das ocupaçóes de 2016}

Quando o cenário de luta na educação se radicalizou, nos encontrávamos na metade do semestre e fomos levados a refletir sobre como poderíamos, criteriosamente e do nosso lugar de pes- 
quisadores, nos aproximar dos eventos que pulsavam com mais força nas escolas e nas ruas. Na última semana de outubro, quando as primeiras ocupaçóes em escolas já haviam começado em nossa cidade, iniciamos a aula com a discussão do texto previsto, mas logo uma doutoranda, comovida, se disse constrangida porque tanto seus colegas professores como seus alunos estavam em greve, ocupando sua escola, e ela, tão comprometida com a defesa da educação quanto eles, ali estava tendo sua aula normalmente na universidade.

A fala da jovem professora foi um momento de virada na disciplina. A partir dali, decidimos por unanimidade que as ocupaçóes seriam os espaços educativos para os trabalhos em grupo. A fundamentação teórica e subjetiva comum que havíamos construído, até então, possivelmente serviu de base para a clara urgência de que se revestiram as açôes, e nesse mesmo dia outra doutoranda sugeriu que gravássemos um vídeo para compartilhar com os estudantes das ocupaçóes, manifestando solidariedade a eles.

Apesar do receio inicial de que algum aluno pudesse se sentir pressionado e constrangido, todos os depoimentos, cerca de 20, foram entusiasmados, afetuosos, colocando-se inteiramente ao lado dos secundaristas em suas açóes de resistência: "Olá, secundaristas, nós somos estudantes de pós-graduação em Educação, estamos atentos e acompanhando tudo o que vocês estáo fazendo, muito interessados e dispostos a colaborar com vocês"; "Força, pessoal"; "Obrigada!"; "Orgulho de vocês"; foram algumas das mensagens daquele vídeo singelo que logo chegou às ocupaçóes.

A materialização desse discurso plural e ao mesmo tempo aberto às singularidades da palavra e dos gestos de cada um foi um marco importante no processo, construindo o grupo enquanto um coletivo com maior grau de autonomia. Não só a agilidade do celular favoreceu a passagem imediata da ideia ao ato de fazermos aquela gravação fundante, como também foram vitais as decisóes, tomadas nesse mesmo dia, de criarmos um grupo de WhatsApp da 
turma e de utilizarmos mais intensamente o ambiente da disciplina no Moodle, para compartilhamentos de materiais e reflexóes.

Foram semanas muito intensas em que cada dupla ou grupo se aproximou de uma escola ocupada, colocando-se ao lado dos estudantes da forma que cada movimento local julgasse adequada. Alguns ofereceram oficinas e aulas públicas nas ocupaçóes, sobre temas como redação para o vestibular, leitura crítica das mídias, violências nas redes sociais. Outros contribuíram com mediações, arrecadação de mantimentos, divulgação, sugestóes em relação à segurança e inúmeras outras formas de apoio concreto. Cada um participava de acordo com as suas possibilidades e tudo era compartilhado pelo grupinho de Whats $A p p$, onde foram problematizadas situações, combinadas ações, compartilhadas angústias.

Enquanto os estudantes buscavam articular os conceitos-eixo do Mapa Conceitual ao seu contexto de imersão nas ocupaçôes, nós professoras pudemos observar que a própria disciplina em sua guinada mais ativista se tornou um espaço privilegiado para o desenvolvimento de autonomia, empoderamento, protagonismo e gestão em rede. As trocas comunicativas do grupo ECOAção no WhatsApp Messenger eram a melhor expressão desse acontecimento, pois evidenciavam a corporificação dos discursos, tanto da teoria como das reflexôes do Cultura Viva em nossa ação concreta e prática. Por essa razão nos debruçamos sobre esses dados para uma investigação.

\section{Espaços de possibilidade: o grupo ECOAçáo no WhatsApp}

Como o ambiente comunicativo privilegiado do grupo, que se esparramou pelas ocupaçóes, mas se manteve conectado por meio do aplicativo, aprendemos juntos a trabalhar em rede e pudemos observar que dentre os quatro conceitos-chave dos Mapas Conceituais, havia uma centralidade da gestão em rede, referendando que "empoderamento e autonomia não são dados, 
são construídos, e a gestão em rede é um meio para alcançá-los" (BRASIL, 2009, p. 73).

Buscamos neste artigo identificar o que propiciou a gestão em rede e, a partir dela, o desenvolvimento dos outros eixos (empoderamento, autonomia e protagonismo) dentro do contexto da turma da disciplina Educação, Comunicação e Cultura do PPGE/UFSC em 2016-2. Esta análise não tem a pretensão de ser uma amostra ou modelo de docência e/ou ação coletiva, mas de poder encontrar, a partir desta vivência, algumas chaves que apontem espaços de possibilidade para a formação cidadã e o uso crítico e criativo das mídias.

Do ponto de vista metodológico, o processo ganhou contornos próximos aos de uma pesquisa participante, abordagem em que "a escolha dos problemas [...]tem sua origem nas situaçôes sociais concretas", e onde a pesquisa "intervém em situaçóes reais e não em situaçóes de laboratório" (LE BOTERF, 1984, p.72-73). A partir da imersão participante em situaçóes concretas, nos aprofundamos na problematização dos processos à luz do referencial teórico proposto e na nossa prática docente. Nossas hipóteses surgiram das vivências pessoais e coletivas, principalmente das conversas no WhatsApp.

A análise teve como fonte um corpus de dados latente da internet (BARTOLOMÉ PINA; NERI DE SOUZA; LEÃO, 2013), com as postagens realizadas de 25 estudantes e duas professoras entre outubro de 2016 e março de 2017 no grupo. Foi extraído em vários formatos, textos, imagens, áudios e vídeos, e foi tratado e analisado, ainda de modo exploratório, como registro de uma pesquisa interessada em conhecer melhor o processo que estava ocorrendo nas ocupaçôes. A aproximação dos estudantes ao movimento que se dava nas escolas, buscando conhecê-lo, apresentou características da pesquisa-intervenção, no sentido assim descrito por Passos e Barros (2009, p. 31):

Conhecer a realidade é acompanhar seu processo de constituiçáo, o que não pode se realizar sem 
uma imersão no plano da experiência. Conhecer o caminho de constituição de dado objeto equivale a caminhar com esse objeto, constituir seu próprio caminho, constituir-se no caminho.

Essa aproximação foi marcada por um grande cuidado em respeitar o protagonismo dos secundaristas. Os universitários estavam ali para observar, colocar-se ao lado, conhecer e compreender as tensóes em jogo - diretamente ligadas à relação política entre educação, comunicação e cultura, mas sem pretensão à neutralidade: buscava-se um conhecer solidário e ativo.

Essas marcas estão presentes também na leitura das interaçóes no grupo de WhatsApp que fazemos neste artigo. Apresentamos a análise a partir de elementos relevantes para o fomento do conceito-eixo gestão em rede, que foram destacados no documento síntese do Seminário Cultura Viva. A compreensão é de que este eixo articula os outros três, autonomia, empoderamento e protagonismo, de modo que eles todos "aparecem" a partir dele.

O esforço é de identificar nas trocas discursivas que ocorreram no contexto da nossa vivência aqueles princípios elencados pelo coletivo do Seminário Cultura Viva. Principalmente em duas dimensóes: nas condiçóes do espaço (o que deveria caracterizar esse espaço) e nas condiçóes dos sujeitos que se apropriam dele (que fatores favorecem uma apropriação crítica dos sujeitos nestes espaços).

\section{Gestáo em rede}

Partimos do princípio de que "não existe rede sem pessoas. Temos que abstrair as instituiçóes e olhar quem são as pessoas que interagem na rede" (BRASIL, 2009, p. 71). Portanto, apesar de reconhecermos que o WhatsApp não é o propulsor da conexão entre as pessoas, compreendemos que ele tem um papel importante por criar um espaço propício para os conteúdos e açóes humanas 
que acolhe. $\mathrm{O}$ valor está na colaboração e na gestão compartilhada e cooperativa desta rede que acontece por meio dele. Mas o que caracteriza a gestão em rede?

\section{- O QUE É GESTÁO EM REDE?}

Uma primeira dimensão se refere ao que deveria caracterizar o espaço como uma gestáo em rede. Trazemos a seguir exemplos presentes nos diálogos do ECOAção de características da gestão em rede apontadas no documento do Programa (BRASIL, 2009, p. 71-72):

\section{- Compartilhamento de ideias}

Aluna O: Pessoal, quem tiver indo nas ocupaçóes se puder tirar umas fotinhos só pro nosso grupo aqui. Foto dos espaços pra quem não pode ir imaginar um pouco. [...]

Professora BB: Acho importante a gente ter claro que nosso papel não é jornalístico, certo?! Não estamos propondo ser uma mídia alternativa, nem alternativa da alternativa...

Aluna O: Se eles não querem que filme e fotografe tem que respeitar. Nada de fotos e nem filmagem. Acho que nem para registro interno, pq sempre pode vazar.

\section{- Trabalho em conjunto}

Aluna S: Gente, seguinte: nossa turma de seminário de comunicação manifestou também o mesmo incômodo. Estamos aqui conversando essa estratégia de somar forças às ocupaçôes das escolas. Como vocês se sentem com a ideia de agregarmos esses alunos nesse grupo daqui?

Aluna I: Maravilha!!!Tamujuntu

Aluna S: Vou esperar todos se posicionarem, tá?

- Soluçáo de problemas

Professora BB: Gente, qual era a escola que tinha muito mosquito? Consegui doação de 2 ventiladores [...] 
Aluna M: É [a Escola Y], tem um matagal atrás. Quer que eu peça para alguém buscar? [...]Tem uma mãe de um aluno que está ajudando na ocupa e mora na Trindade. Posso falar com ela pra buscar.

A seguir, diálogos sobre o impasse causado pela organização do Exame Nacional do Ensino Médio (ENEM), que à última hora cancelou a realização das provas no Centro de Educação ocupado, apesar de haver o comprometimento dos estudantes de acolher as provas no local:

Professora AA: Acabei de falar com o [Estudante Z], que está na ocupação. Ele disse que o INEP cancelou o Enem também no CED. E enfatizou que é muito importante que a gente vá até lá. [...]

Professora BB: A gente já viu, esta é uma, a primeira, estratégia pra deslegitimar o movimento. Estamos cientes, certo? Bora não permitir que essa provocação afete a tranquilidade daquela porta..

Professora AA: Pessoal, acabei vindo, estou aqui na porta do CED...

Aluna S:Tou chegando, [professora AA]. Parei pra almoçar rapidinho.

\section{- Articulaçáo na distribuiçáo}

Aluna M: Gente, [...] uma profe falou comigo pra ver se alguém pode ir lá fazer cobertura da assembleia. Eles querem registrar pra fazer um documentário futuramente e pra própria proteção pq estâo com medo das açôes do grêmio que é contra as ocupaçóes

Aluna J:To indo aí [na escola Z] :) Chego em meia hora. Chegando.

Aluna S:Hj não deu pra mim, amanhã posso colar! Alguém planejando dar um pulo lá amanhâ? [...]

Aluno E: Show. Carreguem celulares. Levem bloco de notas e canetas. Partiu ocupação

Aluna I: Partiu aqui Tb 
- Troca de experiências

Aluna J (áudio): Explicamos pra ela de onde que veio a nossa inquietação [...] Falamos da fala da Aluna B....enfim. [...] Foi bom ouvir o ponto de vista de quem está do outro lado e com outras preocupaçóes. [...] Ficou um alerta pra gente de que a coisa é muito complexa, exige muito diálogo. [...] Tá rolando ali um processo muito rico. E a gente como pesquisador mesmo precisa se aproximar...

- Rompimento de estruturas hierárquicas (BRASIL, 2009, p. 72)

Num determinado momento, ocorreu no grupo uma discussáo sobre algo que tinha sido decidido pela assembleia dos estudantes de pós-graduação e as professoras fizeram ponderaçōes sobre o assunto. Uma das estudantes então se manifestou de modo delicado, mas ao mesmo tempo firme, informando melhor as próprias professoras que se tratava de deliberaçáo da assembleia. Estas pediram desculpas e a conversa prosseguiu, em clima de intimidade e confiança:

Professora BB: Tá certo. Desculpem aí que me meti em um assunto de vocês, e já definido. Foi mal...

Aluna I:Tamujunto Aluna D :) abraço com carinho também

Professora AA: Eu também assino embaixo da Professora BB. Beijos, queridos, boa noite.

Aluna D: Gratidão pela compreensão. Mas que fique claro que não é uma fala pra calar ninguém. Super convido todos a me contrapor rsBoa noite

- Inovaçáo na gestáo de informaçóes e compartilhamento e complementaridade de açóes

A troca de informaçóes foi constante e rica, articulando de forma rizomática a rede interna da turma com as diferentes redes ativistas. 
Aluno E: Estamos acompanhando a deliberação da [escola Z] por meio do whats e já era previsto.

Aluna J: Aluno E! Não estou neste grupo! Me inclui lá?

Aluna S: Bom dia, gente. Aluno E, qual o nome desse grupo? Eu tou em um que não estão falando muito..

Aluna D: Gente. A reuniáo da [escola Z] foi muito complicada. [...] O grupo da ocupa optou por se retirar. Apesar disso sugeri a aula pública e vou passar os detalhes a eles por whats. Terão uma reunião amanhã entre eles para dialogar sobre isso e outras coisas.

Professora AA:Preciosa ponte, Aluna D.

\section{- QUEM PODE EXERCER CADA FUNÇÁO NESTE COLETIVO?}

Uma segunda dimensão da gestão em rede diz respeito aos sujeitos que se identificam com o coletivo e dele participam e aos fatores que favorecem uma apropriaçáo crítica. Como sintetiza um dos participantes do seminário do Programa Cultura Viva: "A gente não trabalha sozinho. A gente precisa estar com o outro, só assim a gente consegue melhorar a sociedade" (BRASIL, 2009, p. 71). A seguir, citamos as características demandadas dos sujeitos (BRASIL, 2009, p. 71-72) para que haja a gestáo em rede, associando-as a exemplos dos diálogos no grupo ECOAçáo.

\section{- Reconhecimento e promoçáo das capacidades dos participantes}

Aluna I: Gente, outra coisa: os alunos querem montar um calendário na semana que vem com aulas para a comunidade focadas no Enem. Eles precisam de todas as áreas.

Aluna J: Eu posso me preparar para dar uma aula de redação. Adoro :))

Aluna I: Opa :) que legal Aluna J contato para eles? 
- Busca de descentralizar o processo e os recursos: "Se tiver hierarquia náo é rede"

Aluna I: Olá, pessoal. Grupo criado!!! Como somos um coletivo, todos se tornam responsáveis pelo grupo e portanto administradores, ok? Sintam-se à vontade de colocar um foto que nos represente

Aluna J: Sugiro essa, que tirei hoje no aplicação! Mas sem apegos...

\section{- Autonomia}

Aluna J: Inclusive, o prof. [da escola W] falou do interesse em debates sobre as TIC. Professora BB e Professora AA, ele perguntou agora se poderíamos participar de uma reuniáo com o diretor, terça à tarde.

- Inteligência coletiva, iniciativa, "gente que mantenha a rede viva"

Aluna S: Gente, pensei numa coisa, veja se vcs acham que é muita pira, tá?! Rs. Pensei da gente criar uma "corrente" de Facebook , [...] Desafiando os amigos pra irem numa ocupação e fazerem uma ação. [...] .. muita viagem?

Aluno E: Sim viagem! Kkkkk mas eu amei!!

Aluna S: Rs, tá bom

Há também muitas imagens de apoio dos outros pós-graduandos que trabalhavam e não podiam estar tấo presentes nas açôes. Eles iam mantendo o ânimo no grupo, curiosos e com mensagens de afeto.

\section{- Entrelaçamento de conceitos}

Diversos áudios postados no grupo mostram o protagonismo da turma, que se sentiu fortalecida (empoderamento) para a ação política pelo grupo e foi às ocupaçóes para ouvir e apoiar os secundaristas. Propuseram articulaçôes, aulas abertas (autonomia), trouxeram demandas para organizar o grupo, sugeriram a produçáo 
de um vídeo para levarem de uma escola para outra com troca de experiência e apoio (gestão em rede).

[Áudio - Relato da Aluna S sobre a Escola W]:Participamos de um sarau aberto. Conversamos com um professor que estava acompanhando os jovens, pegamos contatos. Aluna J deu ideia de gravarem mensagem deles pra levar pra [Escola Z], pra eles demonstrarem apoio aos estudantes da outra escola e contar o que já aprenderam no processo. Professor [da escola W] sugeriu conversarmos com a direção pra sermos parceiros "oficiais" e facilitar o acesso no futuro.

\section{- Criaçáo de teia com socialização de experiências}

Aluna D: Pessoal, [...] conversamos com os estudantes e fizemos a pergunta: do que precisam? Uma das primeiras demandas foi: advogados.Passei o contato de dois dos Advogados Ativistas [...]A segunda [...] é: ajudar a trazer oficinas, palestras, tudo o que for acrescentar às rotinas de ocupação. Outra coisa: eles tem um grupo de Whatsapp no qual já estamos eu e Aluna H. Alguém mais quer disponibilizar seu número para acompanhar os diálogos?

Aluno E: Eu. Tel XX.

\section{Consideraçóes finais}

A riqueza da experiência político-pedagógica relatada acima está longe de ter sido completamente analisada e mesmo compreendida por todos nós que participamos dela. Esperamos, porém, que tenham ficado claros alguns indícios do grande potencial educativo de articulaçóes como as que a embasaram. Dentre elas, estão os laços entre: um conjunto de conceitos mobilizadores de políticas culturais democráticas; um grupo de educadores dispostos a explorar tais conceitos, colocando-os em operação; a vitalidade de um movimento social impulsionada por uma justificada indignação contra ataques à educação; um dispositivo técnico-cultural - o Whats $A p p$ - que permitiu uma comunicação particularmente poro- 
sa e flexível, aberta tanto à intimidade como à viralização, adequada às irrupçóes e instabilidades materiais e afetivas de toda ordem que marcaram o movimento das ocupações das escolas em 2016.

Em relação à gestão em rede, foco principal desta nossa discussão, podemos dizer que ela ocorreu por um esforço coletivo de qualificar o que se fazia, com transparência, solidariedade e compromisso com o grupo. Mas sem dúvida, considerando que a turma estava espalhada entre os diferentes lugares e tempos das escolas ocupadas, foi vital a possibilidade que o aplicativo garantiu, de manter todos sempre próximos e acompanhados.

Quem se deparava com um impasse em sua frente de atuação sabia que estaria sempre a poucos cliques de distância de alguém que poderia ajudá-lo a decidir o que fazer, alguém com quem já tinha estudado junto os mesmos textos, debatido longamente cada questão, nos meses de aulas presenciais que tínhamos compartilhado. As trocas pelo WhatsApp permitiram que o grupo pulsasse junto ao longo de semanas. E esse pulsar junto, sabíamos, reverberava a vibração de milhares de outras redes ativistas de educadores que, em nossa cidade e pelo Brasil afora, exerciam também suas próprias formas de gestão em rede.

A experiência mostrou, assim, um caso em que instâncias comunicativas criadas na dimensão micro da sala de aula puderam se articular a redes ativistas externas à instituição, porém voltadas aos mesmos horizontes temáticos, éticos e políticos do programa curricular que se pretendia desenvolver. Nos reconhecemos, assim, em uma situação semelhante àquela descrita no documento que nos inspirou: "Nos Pontos de Cultura a gente constrói o fazer. Nas escolas o fazer está pronto. As crianças quando têm uma vivência nova, elas mesmas começam a transformar a escola” (BRASIL, 2009, p. 71). 


\section{Referências}

BARTOLOMÉ PINA, A. R.; NERI DE SOUZA, F.; LEÃO, M. C. Investigación educativa a partir de lainformación latente en Internet.

Revista Eletrônica de Educaçáo, v. 7, n. 2, p. 301-316, 2013.

Disponível em: <http://www.reveduc.ufscar.br>. Acesso em: nov. 2016.

\section{BRASIL: Seminário Internacional do Programa Cultura Viva:}

Novos Mapas Conceituais. Ministério da Cultura, Pirenópolis, 2009.

BOTTENTUIT JR., J.B.; ALBUQUERQUE, O.C.P;

COUTINHO, C.P.: Whatsapp e suas aplicações na Educação: uma revisão sistemática da literatura. RevistaEducaOnline (UFRJ), Rio de Janeiro, v. 10, n. 2, maio/ago. 2016.

BUCKINGHAM, D. Media education: literacy, learning and contemporary culture. Cambridge: Polity Press, 2005.

CASTELLS, M. Redes de indignaçáo e esperança: movimentos sociais na era da internet. Tradução de Carlos A. Medeiros. Rio de Janeiro: Zahar, 2013.

FREIRE, P. Pedagogia da Esperança. Rio de Janeiro: Paz e Terra, 1998.

\section{GARCÍA CANCLINI, N. Diferentes, desiguais e} desconectados: mapas da interculturalidade. Rio de Janeiro: UFRJ, 2009.

GUPTA, A.K.: Scope and Implications of Social Media in the Context of Higher Education: Review of Researches. MIER Journal of Educational Studies, Trends \& Practices, v. 4, n. 2, p. 231-253, nov. 2014. 
LE BOTERF, G. Pesquisa participante: propostas e reflexóes metodológicas. In: BRANDÃO, C.R. (Org.) Repensando a Pesquisa Participante. SP: Brasiliense, 1984.

MARTÍN-BARBERO, J. Dos meios às mediaçóes: comunicação, cultura e hegemonia. Rio de Janeiro: UFRJ, 2009.

PASSOS, E.; BARROS, R. B. A cartografia como método de pesquisa-intervenção. In: PASSOS, E.; KASTRUP, V.; ESCÓSSIA, L. Pistas do Método da Cartografia: pesquisaintervenção e produção de subjetividade. Porto Alegre: Sulina, 2009.

SANTOS, B.S. A difícil democracia: reinventar as esquerdas. São Paulo: Boitempo, 2016.

WELLMAN,B; GULIA, M. Virtual Communities as communities: net surfers' don't ride alone. In: SMITH, M. A.; KOLLOCK, P. Communities in cyberspace. London: Routledge, p. 167-194, 1999.

WILLIAMS, R. A. Cultura é de todos (Cultureisordinary). In: CEVASCO, M. E. Para ler Raymond Williams. São Paulo: Paz e Terra, 2001. 


\title{
O WHATSAPP COMO DISPOSITIVO PEDAGÓGICO PARA A CRIAÇÃO DE ECOSSISTEMAS EDUCOMUNICATIVOS
}

\author{
J. António Moreira - UAB-PT \\ Sara Dias Trindade - UC-PT
}

\section{Introdução}

Nas sociedades atuais a importância das tecnologias digitais móveis tem vindo a acentuar-se por via do desenvolvimento social e econômico e da sua cada vez maior presença no quotidiano, com impactos na forma como a interação e a comunicaçấo ocorrem. As suas potencialidades contribuem para que sejam consideradas ferramentas incontornáveis na criação de ecossistemas digitais educomunicativos e no desenvolvimento de estratégias de aprendizagem motivadoras para a aquisição de competências pelos estudantes, cada vez mais imersos no mundo digital. Com efeito, estes ecossistemas digitais de aprendizagem, tal como os conhecemos, estáo a ser constantemente desafiados pelo enorme fluxo de conteúdos e pelas múltiplas plataformas, inclusive de instant messaging, que circulam pela nossa cultura e que provocam um conjunto de mudanças, náo só tecnológicas, mas também sociais e culturais (JENKINS, 2009).

Associados ao campo educativo, e com a disseminação das tecnologias e o crescente acesso à Internet, o termo ecossistemas digitais de aprendizagem tem ganho um significado cada vez mais relevante. $\mathrm{O}$ desenvolvimento de ecossistemas constituídos por 
ambientes de aprendizagem complementares requer, cada vez mais, uma mudança significativa na forma de pensar o ato educativo. $\mathrm{O}$ desafio passa, e recorrendo ao conceito de Ecologia, por criar ambientes férteis, dinâmicos, vivos e diversificados onde as atividades de aprendizagem, o conhecimento e as ideias possam nascer, crescer e evoluir. E para isso é necessária uma abordagem que não se limite a considerar apenas os aspetos tecnológicos relacionados com uma aprendizagem via web (eLearning), mas que privilegiem uma abordagem ecológica, integrada e holística.

É neste contexto que o WhatsApp, hoje acessível de uma forma quase generalizada em diferentes dispositivos móveis, se afirma, proporcionando a docentes e estudantes oportunidades de aprendizagem desenhadas “à medida” e passíveis de serem concretizadas em praticamente qualquer lugar, a qualquer hora. Contudo, numa era de mudança de paradigma educativo, onde cada vez mais se atenua a linha que separa a educação formal da informal e não formal, é importante perceber como otimizar as potencialidades deste tipo de plataformas, de software social. É, pois, objetivo deste capítulo refletir sobre a aplicabilidade pedagógica do WhatsApp, procurando analisar possibilidades, potencialidades e fragilidades do mesmo na criaçáo e desenvolvimento de ecossistemas digitais educomunicativos em diferentes níveis de ensino, nomeadamente em nível do Ensino Superior.

\section{A aprendizagem Mobile e os ecossistemas educomunicativos em rede}

O acesso à tecnologia, em particular à móvel, tem contribuído para modificar a forma como as pessoas interagem quer entre si, quer com os conteúdos a que têm acesso. Esta nova forma de pensar o acesso à informação tem também tornado cada vez mais propícia a utilização deste tipo de tecnologias em ambiente de ensino, permitindo formas crescentemente sofisticadas não só de acesso aos conteúdos, mas também de interação e de partilha dos mesmos. 
As potencialidades dos dispositivos móveis tornam-os, assim, ferramentas incontornáveis no desenvolvimento de estratégias de aprendizagem motivadoras e também proporcionadoras do desenvolvimento de competências diversas pelos estudantes, uma vez que facilitam uma interação entre aquilo que são as suas competências sociais digitais e uma atitude mais ativa e construtivista no que diz respeito ao acesso ao conhecimento.

É por isso que o mobile learning é hoje um conceito cada vez mais integrado no universo da educação. É preciso reconhecer que "a capacidade que os alunos têm de aceder à informação com a rapidez de um clique ou do deslizar de um dedo, torna o uso de tecnologias [...] na educação cada vez mais uma realidade" (TRINDADE, 2015, p. 207). Por um lado, as tecnologias digitais são hoje uma realidade presente em praticamente todo o lado e, por outro, estamos já plenamente conscientes de que os estudantes de hoje nasceram já em plena era tecnológica.

Assim, torna-se necessário repensar os modelos pedagógicos a seguir, de forma a adequá-los ao novo tipo de estudantes que passam hoje pelas salas de aula. Como refere o último Horizon Report para o Ensino Superior (BECKER et al., 2017), as instituiçóes que náo adotarem estratégias que incluam um ensino online, mobile e blended não conseguirão sobreviver. De facto, o mundo educativo encontra-se frente a uma enorme transformação, resultado da revolução digital.

Aos docentes, cabe-lhes perspectivar uma nova forma de ensinar, o que, claro, carece de investimento, de formação e, sobretudo, de alguma audácia. E todo esse esforço serve para que se consiga que as tecnologias digitais que são utilizadas não sejam apenas um mero recurso mas sim,

[...] uma estratégia integrada num pensamento e prática pedagógica, que visem desenvolver competências de acesso e utilização crítica da informação 
que, no quotidiano, chega aos jovens de forma imediata, não filtrada e com níveis de autenticidade e qualidade muito variados (TRINDADE; RIBEIRO, 2016, p. 180).

Adotar esta postura pode contribuir para produzir resultados bastante positivos, nomeadamente no que diz respeito ao desenvolvimento de práticas motivadoras, estimulantes e que poderão reavivar o interesse dos estudantes pelo que a escola lhes pode ensinar. De facto, tal como refere Barkley (2010, p. 7), “a motivação e a aprendizagem ativas trabalham em conjunto, de forma sinergética, e enquanto interagem, contribuem exponencialmente para aumentar o engajamento"'.

Importante é perceber que podem ser criadas pontes entre o que é considerada uma aprendizagem formal e uma aprendizagem informal. Nesse sentido, e como refere a Organização das Naçóes Unidas para a Educação, Ciência e Cultura (UNESCO, 2014, p. 21), "a aprendizagem contínua ou seamless é uma forma de aprendizagem em que não há interrupçóes entre os diferentes ambientes - incluindo contextos formais e informais". Para além disso, partindo destas pontes que podem ser criadas, podemos passar para um ecossistema educomunicativo que se foca na rede, nas conexóes e na partilha de informação, beneficiando dessa colaboração ativa entre os participantes do processo educativo para construir cada vez mais e melhor conhecimento.

Estamos, de facto, perante uma nova realidade: a de uma geração para quem "na partilha está o poder" (PRENSKY, 2010, p. 280), para quem o mundo permanentemente conectado permite o alcance de mais informação do que aquela que, há bem poucos anos atrás, seria possível aceder. Nesse sentido, é importante fazer

\footnotetext{
1 "motivation and active learning work together synergistically, and as they interact, they contribute incrementally to increase engagement" (tradução dos autores).

2 "sharing is power" (tradução dos autores).
} 
uso das redes, das conexóes que conseguimos criar. Tal como refere Siemens (2006, p. 7, tradução nossa), "dançamos e cortejamos o conhecimento dos outros"3, pelo que se torna muito importante alargar a experiência de aprendizagem não só ao que o indivíduo pode aprender, mas também ao que aqueles que se encontram em seu redor sabem.

Stephen Downes (2011, tradução nossa), outro grande defensor das ideias do conectivismo, apelida-a de "pedagogia assente na rede" ${ }^{4}$, baseando-a na ideia de que o conhecimento se encontra distribuído por meio de redes de relaçóes e que a aprendizagem consiste na capacidade de construir e cruzar essas mesmas redes (DOWNES, 2010).

Encontramo-nos, por isso, face a uma mudança de paradigma da educação, potenciada pela vertiginosa evolução das tecnologias que hoje permitem criar ecossistemas educomunicativos digitais onde o funcionamento em rede e o trabalho colaborativo podem assumir o papel principal na educação. De facto, são hoje mais que muitas as possibilidades criadas pelo desenvolvimento de aprendizagens colaborativas, que vão buscar o "poder das açóes do coletivo" (SELWYN, 2012) e que têm na tecnologia um poder importante para a sua implementação: seja a nuvem, os aplicativos ou tantas outras ferramentas digitais, as quais promovem uma "conectividade constante, ajudando estudantes e educadores a aceder e contribuir, em qualquer altura, a espaços de trabalho partilhados" (BECKER et al., 2017, p. 20, tradução nossa).

Tem aqui um papel importante o desenvolvimento da mídia social, cujas potencialidades ao nível da construção e partilha de informação permitem a sua integração no paradigma da web 2.0, integrando-se perfeitamente na sua lógica de "construção de conhecimento que

\footnotetext{
3 "we dance and court the knowledge of others"

4 "network-based pedagogy"

5 "persistent connectivity, enabling students and educators to access and contribute to shared workspaces, anytime"
} 
foi adquirida em redes de aprendizagem globalmente diversificadas" 6 (TESS, 2013, p. A62, tradução nossa).

De facto, os jovens do novo milénio estáo cada vez mais habituados a um permanente multitasking e a fazer uso do digital para coordenar todas as suas atividades diárias (SELWYN, 2012). Estão, sobretudo, familiarizados com as vantagens de uma existência digital colaborativa, participativa e onde novas formas de ensinar e de aprender têm de ser estruturadas, tirando partido das inúmeras possibilidades que os novos aplicativos, que se veem multiplicando a uma velocidade cada vez maior e que náo podem mais ser vistos como uma disrupçáo no contexto de educação, mas sim como uma ampliação do campo educativo.

Para além disso, por meio do desenvolvimento de estratégias de aprendizagem que fazem uso da tecnologia como forma de potenciar o construtivismo, o foco da educação passa a centrar-se na dialética e na dinâmica construída entre o professor e o estudante; este último, de mero receptor e consumidor do conhecimento, passa a integrar-se (até mesmo de forma quase inconsciente) num processo de ativa participação na construção desse mesmo conhecimento (SELWYN, 2012; AL-RAHMI; OTHMAN, 2013; MOREIRA; JANUÁRIO, 2014; TRINDADE, 2015). Cria-se, pois, uma nova geração de estudantes, a que poderemos chamar de "produsers" (SELWYN, 2012), que aprendem por meio da criaçáo e da partilha dos seus próprios conhecimentos, beneficiando-se não só do acesso à informação já existente na rede, mas também da capacidade de, a partir dela, contribuir para a criação de novo conhecimento.

Neste contexto, Selwyn refere que, para além das crescentes capacidades destas novas geraçóes para algum multitasking, uma vez que gerem no seu quotidiano diferentes ferramentas tecnológicas,

6 "knowledge construction that was vested in globally diverse networks of learning". 
mais sutilmente, essas tecnologias também estão associadas a uma maior autonomia social - com os jovens agora habituados a ter maior controle sobre a natureza e forma do que fazem, bem como onde, quando e como o fazem. ${ }^{7}$ (SELWYN, 2012, p. 2, tradução nossa).

Estas possibilidades transformam assim os ecossistemas de aprendizagem, tendo o professor de desenhar e arquitetar diferentes ambientes que explorem as imensas potencialidades das mais variadas plataformas da Web 2.0.

Por esse motivo e por mais que subsistam entre alguns autores dúvidas sobre a verdadeira aplicabilidade educativa da Web 2.0 e de todos os seus recursos, parece fazer cada vez menos sentido "manter modelos de organização curricular "pré-digitais" centrados numa organização rigidamente hierárquica de conteúdos estáticos sob o controlo do professor" (MOREIRA; JANUÁRIO, 2014, p. 68).

\section{O WhatsApp como dispositivo pedagógico}

O Whats $A p p$ vem ganhando cada vez maior importância nas correntes de pensamento contemporâneo sobre Educação, uma vez que é um aplicativo que está hoje disponível para a maioria dos smartphones existentes no mercado e que permite não só a troca de mensagens escritas, mas, também, a troca de imagens, vídeos, áudio e documentos.

De facto, este aplicativo permite aos seus utilizadores, de uma forma bastante simples, manter o contato com amigos ou colegas, dependendo apenas de uma ligaçáo à Internet para ser informado, em tempo real, de qualquer update realizado. Esta questáo,

7 "more subtly, these technologies are also associated with an enhanced social autonomy-with young people now used to having increased control over the nature and form of what they do, as well as where, when and how they do it." 
aliada ao seu baixo custo, acessibilidade, eficiência e linguagem natural tornam o Whats $A p p$, cada vez mais, uma ferramenta mais atrativa para uso em ambiente educativo do que muitas outras existentes no mercado (CHURCH; OLIVEIRA, 2013; BOUHNIK; DESHEN, 2014).

Como tem uma interface muito intuitiva, o WhatsApp tem vindo a ter cada vez mais utilizadores, que dele fazem uso para comunicação instantânea com um ou mais elementos da sua lista de contatos. E foi esta mesma simplicidade que lhe valeu o "bilhete" de entrada na sala de aula:

O WhatsApp pode ser a primeira tecnologia que entrou na sala de aula sem qualquer treino ou supervisão de um administrador, já que professores e alunos usam isso na sua vida privada, e suas vantagens permitiram que ele se tornasse, naturalmente, uma tecnologia educacional. ${ }^{8}$ (BOUHNIK; DESHEN, 2014, p. 229, tradução nossa).

A introdução das tecnologias na sala de aula foi sempre alvo de alguma controvérsia por parte de quase toda a comunidade escolar. Muitas questóes assentavam no facto de muitos professores apresentarem uma certa "tecnofobia", fruto de não sentirem um verdadeiro controle sobre o que deve ser a interação entre a tecnologia e a educação, no sentido de criar ecossistemas de aprendizagem eficazes, sobretudo por causa da rapidez com que evoluem quer os equipamentos, quer os próprios aplicativos digitais.

Porém, é importante que as estratégias educativas sejam pensadas e adequadas a estes estudantes do novo milênio, que procuram agora novos estilos de ensino e novas formas de motivação

8 "WhatsApp might be the first technology that entered the class without any training or administrator supervision, as teachers and students are using it in their private life, and its advantages enabled it to be become, naturally, an educational technology." 
(BAWA; IBRAHIM, 2016). Nesse sentido, Paiva, Ferreira e Corlett (2016, p. 758) referem que,

[...] quando Freire [...] caracteriza o modo de ensinar, explica que cabe ao docente escutar o educando para poder saber falar com ele. Isso implica que cabe ao docente o dever de estar em um ambiente que seja confortável para o educando (neste caso a ferramenta Whats $A p p$ ) e utilizando também de uma linguagem que o receptor possa compreender.

As novas geraçóes estão habituadas a desenvolver tarefas com base no toque do dedo, interagindo com múltiplas fontes de informação diferentes, não raras vezes ao mesmo tempo, pensando cada vez mais de uma forma não linear. Tal como Brown (2002, p. 14, tradução nossa) escreve,

A nossa observaçáo de crianças trabalhando com a mídia digital sugere bricolage para nós mais do que lógica abstrata. Bricolage é um conceito estudado por Claude Lévi-Strauss [...], e relaciona-se com o concreto. Isso tem que ver com a habilidade para encontrar algo - um objeto, ferramenta, documento, um pedaço de código - e usá-lo para construir algo que se considere importante?

A partilha de informação, que é propiciada pela utilização do WhatsApp, surge de uma forma quase natural, articulada com esta noção de "encontrar algo e usá-lo para fazer um objeto novo", ou seja, pegar em pedaços de informação que chegam até nós, os feeds de mensagens do aplicativo e usar essa informação de forma construtivista,

9 "Our observation of kids working with digital media suggests bricolage to us more than abstract logic. Bricolage, a concept studied by Claude Lévi-Strauss [...], relates to the concrete. It has to do with abilities to find something - an object, tool, document, a piece of code - and to use it to build something you deem important." 
para construir conhecimento novo (AMRY, 2014). É neste contexto que o WhatsApp se consegue converter facilmente num dispositivo pedagógico que permite a criação de ecossistemas educomunicativos que fomentam aprendizagens ativas com autonomia, criatividade.

O próprio papel do professor, neste tipo de comunicação digital, que tanto pode funcionar de forma síncrona como assíncrona, reconfigura-se com o WhatsApp, sendo o conhecimento construído por todos.

Para além desta construção coletiva do conhecimento e em total sintonia com as ideias conectivistas de Siemens e de Downes, verifica-se que o Whats $A p p$ facilita, também, o desenvolvimento de aprendizagens colaborativas na medida em que: "seja espontâneo ou dirigido pelos professores, cria uma atmosfera de cooperação, solidariedade e aproximação para resolver problemas e enfrentar os desafios"10 (BOUHNIK; DESHEN, 2014, p. 229).

Vários autores defendem, por isso, que estes espaços de interação a distância sejam fóruns ou plataformas de instant messaging, conseguem envolver muito mais os atores que integram o processo de ensino e aprendizagem, cooperando e trabalhando em conjunto, ativamente e de uma forma mais rápida, para a construção do conhecimento (AMRY, 2014; KAIESKI; GRINGS; FETTER, 2015, tradução nossa).

A possibilidade de fazer a ponte entre o que é aprendizagem formal em espaço de sala de aula e ambientes mais informais, presentes no quotidiano dos estudantes, contribui também para aumentar exponencialmente a possibilidade de os alunos se apropriarem de situaçóes do seu dia a dia e as utilizarem na produção de mais conhecimento. A interação que podem fazer com os seus colegas por meio da presença constante no mundo digital, transporta, de uns para os outros, todos esses novos dados, criando uma rede

10 "whether spontaneous or directed by the teachers, creates an atmosphere of cooperation, solidarity, and coming together to solve problems and deal with challenges" 
de conexóes que deixa de ser apenas social e passa a ser também educativa (AMRY, 2014; BOUHNIK; DESHEN, 2014; BOTTENTUIT JUNIOR; ALBUQUERQUE; COUTINHO, 2016).

Esta hibridização da educação pode contribuir para aumentar a qualidade do processo de ensino-aprendizagem, uma vez que este deixa de se restringir ao limitado espaço de uma sala de aula e extravasa agora para o quotidiano (físico ou digital). Na verdade, “aprendemos e ensinamos em muitos outros espaços e lugares, [...] graças à mediação das mídias digitais, que canalizam, armazenam e distribuem o saber produzido individual e coletivamente" (LOPES; VAS, 2016, p. 6).

Neste contexto, os professores ganham uma sala de aula ampliada onde podem trabalhar. Por meio das mensagens do What$s A p p$, o docente pode colaborar com os seus estudantes e integrar todos os espaços e todos os tempos, numa "interligação simbiótica, profunda e constante entre os mundos físico e digital” (KAIESKI; GRINGS; FETTER, 2015, p. 2).

Conceição e Schneider (2016, p. 814) questionam o que muda no papel do professor. Muda, de facto, a noção de espaço e de tempo (onde e quando ensinar), mas muda também a forma de comunicar com os estudantes, que passa a movimentar-se de uma forma muito flexível entre os momentos de um "professor convencional" e os de um "gerente de pesquisa, de estimulador de busca, de coordenador de processos e dos resultados".

A presença do professor é fundamental para que a utilização de um aplicativo como o WhatsApp seja verdadeiramente enriquecedora, quer enquanto "arquiteto" e "construtor" do ambiente de aprendizagem, quer também como mediador e facilitador da aprendizagem que se constrói nesse cenário. A comunicação entre o professor e os estudantes contribui para promover o desenvolvimento de uma experiência educacional relevante, para além de proporcionar ao docente um outro tipo de mecanismo para conhecer melhor os seus estudantes, mais individualizada, conseguindo 
assim auxiliar cada um deles no seu próprio processo de construção do conhecimento.

Contudo, existem também algumas limitaçóes na utilização do Whats $A p p$ em contexto educativo. Por um lado, autores como Bouhnik e Deshen (2014) e Nitza e Roman (2016) mencionam a dificuldade em manter uma linguagem adequada e, por outro, alertam para a necessidade de se controlar o fluxo de mensagens, pois, tal como referem também Bottentuit Junior, Albuquerque e Coutinho (2016, p. 81), "são necessários planejamento e cautela, evitandose distração, dificuldades no acompanhamento do fluxo de mensagens e, consequentemente, não se atingir os propósitos educativos”.

Para além disso, encontram-se ainda estudos onde os autores criticam o facto de os estudantes aproveitarem a presença do docente no ambiente criado com o WhatsApp para assentarem nele todo o acesso ao conhecimento, ou seja, sem se esforçarem verdadeiramente para aceder à informação ou para construir as suas aprendizagens, procurando no professor a forma mais rápida de chegar a esse conhecimento, sendo que consideram que o professor deve estar permanentemente disponível para resolver todas as suas dúvidas (BOUHNIK; DESHEN, 2014; NITZA; ROMAN, 2016).

\section{Estudo (s) de caso: perceçóes dos estudantes sobre o Whatsapp}

Tendo em conta as ideias apresentadas no ponto anterior e, considerando que o WhatsApp se apresenta, efetivamente, como uma ferramenta bastante atrativa para usar em contexto educacional, resolvemos avaliar o seu potencial enquanto ambiente online de aprendizagem integrado num ecossistema digital de uma unidade curricular de um curso de pós-graduação que analisa a usabilidade de diferentes ambientes virtuais de aprendizagem, no ano letivo de 2016/2017. 
Assim, com o objetivo de analisar o impacto do ambiente digital na formação e desenvolvimento de uma comunidade virtual de aprendizagem, sobretudo em aspetos relacionados com as dinâmicas comunicacionais criadas no seio dessa comunidade, a partir da análise qualitativa das perceçôes e narrativas de estudantes de um Curso de Pós-Graduação e tendo como referencial o modelo Community of Inquiry (COI), desenvolvemos uma primeira pesquisa (MOREIRA; TRINDADE, 2017a); e com o intuito de analisar o seu impacto no autoconceito académico, em dimensóes como a motivação, a orientação para as tarefas, a confiança nas suas capacidades ou a relação com os pares, desenvolvemos uma segunda pesquisa (MOREIRA; TRINDADE, 2017b).

Quadro 1 - Pesquisas realizadas pelos autores sobre o uso educativo do Whats $A p p$

\begin{tabular}{|c|c|c|}
\hline Título & $\begin{array}{c}\text { Objetivo principal da } \\
\text { pesquisa }\end{array}$ & Metodologia \\
\hline $\begin{array}{l}\text { O Dispositivo Digital } \\
\text { WhatsApp e o seu } \\
\text { Impacto na Criaçáo } \\
\text { de Comunidades } \\
\text { Virtuais de } \\
\text { Aprendizagem }\end{array}$ & $\begin{array}{l}\text { O objetivo foi analisar o } \\
\text { impacto que o Whats } A p p \\
\text { pode ter na criação e } \\
\text { desenvolvimento de } \\
\text { comunidades virtuais de } \\
\text { aprendizagem. }\end{array}$ & \multirow{2}{*}{$\begin{array}{l}\text { Design Based Research } \\
\text { (DBR)- metodologia } \\
\text { que procura pesquisar } \\
\text { problemas educativos } \\
\text { em contextos reais de } \\
\text { atuação pedagógica, } \\
\text { com vista à resoluçáo } \\
\text { de problemas } \\
\text { significativos e } \\
\text { práticos, conciliando } \\
\text { teoria e prática. } \\
\text { A análise de conteúdo } \\
\text { foi a técnica de } \\
\text { investigação utilizada } \\
\text { para obter os dados } \\
\text { referentes ao estudo. }\end{array}$} \\
\hline $\begin{array}{l}\text { Reconfigurando } \\
\text { Ambientes Virtuais de } \\
\text { Aprendizagem com o } \\
\text { WhatsApp }\end{array}$ & $\begin{array}{l}\text { O objetivo foi analisar o } \\
\text { impacto que o Whats } A p p \\
\text { pode ter nível da promoçáo } \\
\text { do autoconceito académico, } \\
\text { em dimensóes como a } \\
\text { motivação, a orientação } \\
\text { para as tarefas, a confiança } \\
\text { nas suas capacidades ou a } \\
\text { relaçáo com os pares. }\end{array}$ & \\
\hline
\end{tabular}

Fonte: Elaborado pelos autores. 
Como quadro conceitual, tomamos como referencial, para o primeiro estudo, e como já referimos, o modelo Community of Inquiry (COI) (GARRISON, ANDERSON; ARCHER, 2000) que assenta em três dimensóes de base: a dimensão cognitiva, social e de ensino; e para o segundo o Modelo Pedagógico Virtual ${ }^{\circledR}$ da Universidade Aberta, Portugal, que assenta num ensino centrado no estudante e promotor de inclusão digital, baseado na flexibilidade de acesso à aprendizagem e na interação.

Como podemos verificar no Quadro 1, em ambas as pesquisas, optamos por uma metodologia de Design Based Research (DBR) que procura, essencialmente, pesquisar problemas educativos em contextos reais de atuação pedagógica, com vista à resoluçáo de problemas significativos e práticos, conciliando teoria e prática.

A análise de conteúdo foi a técnica de investigação utilizada para obter os dados referentes ao estudo, tendo sido realizada por meio da leitura flutuante de todas as respostas ao inquérito, com o intuito de alinhar temas comuns e verificar particularidades em função da individualidade dos casos.

A nossa amostra foi constituída por um grupo de dez e quinze estudantes, respetivamente, para a primeira e segunda pesquisas, e o instrumento que serviu de base para a recolha de dados, em ambas as pesquisas, foi o inquérito por meio de questionário.

A análise documental, o âmbito e os objetivos desenhados para os estudos levou-nos a buscar as referências, para o primeiro estudo, no Community of Inquiry Survey Instrument (COI) desenvolvido por Garrison e colaboradores (2000), posteriormente adaptado por Moreira e Almeida (2011) à população portuguesa; e para o segundo, no Self Concept as a Learner Scale (SCAL) desenvolvido por Waetjen, em 1972, e adaptado por Veiga (1996) à população portuguesa, para construir os nossos instrumentos.

Relativamente à primeira pesquisa, pudemos concluir que a utilização do dispositivo WhatsApp pode, efetivamente, ter efeitos muito positivos na construção de comunidades virtuais de aprendizagem robustas. 
Por meio da análise das perceçóes dos estudantes na dimensão da Presença Cognitiva, pudemos verificar que as estratégias pedagógicas implementadas em conjunto com o aplicativo permitiram criar um ambiente promotor de um processo de pensamento crítico. Concluímos também que os estudantes consideram que o ambiente permitiu fortalecer as relaçóes afetivas entre os elementos da turma, tendo-se partilhado informação e conhecimento, com autonomia, criatividade e de uma forma muito ativa e instantânea. E concluímos, ainda, que os estudantes consideram a presença docente como o elemento base de todo o processo, na medida em que cabe ao professor a tarefa de implementar e desenvolver a comunidade e orientar a aprendizagem dos seus membros.

Por sua vez, no que diz respeito à segunda pesquisa, concluímos que aplicativos como o Whats $A p p$ podem ter efeitos muito positivos no autoconceito acadêmico dos estudantes do ensino superior, em termos das diferentes dimensóes consideradas, quer seja nível da sua motivação, da confiança nas suas capacidades ou da relação com os seus pares. Apenas o nível da organização das tarefas não foram obtidos resultados tão positivos.

Por meio da análise das perceçóes dos estudantes, pudemos concluir que estes consideram este ambiente muito motivante, sentindo-se muito confiantes na interação com o ambiente de aprendizagem. Concluímos, ainda, que este ambiente de aprendizagem online, designado por alguns estudantes como um ambiente "quebra-gelo", permitiu fortalecer os laços sociais entre os elementos da turma. No entanto, é de destacar ainda que os estudantes referiram ter dificuldades em gerir a imensa informação que circulou no ambiente de aprendizagem, sendo que muitos estudos, já citados, identificam também esta fragilidade associada ao enorme fluxo de informação que pode ter um efeito negativo sobre o desempenho acadêmico dos estudantes. 


\section{Consideraçóes finais}

A utilização de recursos digitais na educação é cada vez mais considerada uma realidade incontornável. Cada vez mais as potencialidades das mais diversas aplicaçóes, como o WhatsApp, permitem o desenvolvimento de aprendizagens "à medida" e ao ritmo de cada um (TRAXLER, 2009; TRINDADE, 2015; BECKER et al., 2017).

Um dos aspetos mais importantes da utilização de aplicativos como o WhatsApp é a possibilidade que proporciona de um maior controle das aprendizagens pelos próprios estudantes, que são conduzidos de uma forma intuitiva a adotar uma postura muito ativa perante o processo educativo (SELWYN, 2012).

Verifica-se que, focando a nossa atenção nas potencialidades (e também nas limitaçóes) do WhatsApp, o aplicativo permite uma conexão quase permanente, facilitando, por isso, a interação entre todos os elementos do processo educativo. Para, além disso, a interação propiciada pela troca de diferentes formatos de informação (texto, vídeo, áudio, imagens ou pdf) fomenta, claramente, o desenvolvimento de estratégias construtivistas e colaborativas.

Assim, o que ressalta dos estudos desenvolvidos pelos autores deste texto é que o WhatsApp pode permitir ao docente, a construção de comunidades virtuais de aprendizagem robustas e que pode ter efeitos muito positivos no autoconceito acadêmico dos estudantes, desde que o ecossistema digital online assente nas inter-relaçóes de três elementos nucleares - presenças cognitiva, social e docente - e seja ancorado em ambientes de aprendizagem colaborativa com experiências educacionais de cariz humanista, baseadas na flexibilidade e na interação.

No entanto, perante estes resultados que nos confirmam o enorme potencial deste aplicativo, temos de ter consciência que esta plataforma de mobile instant messaging também apresenta alguns aspetos menos positivos, como o risco de banalização dos conteúdos, o overload e a desorganização das informaçóes. 
Terminamos, referindo que estas plataformas permitem, com efeito, pensar o processo pedagógico de forma distinta. No entanto, a mudança não deve ocorrer apenas nível da introdução de novas tecnologias, mas também em termos culturais, pois obriga a repensar os papéis de todos os atores envolvidos, para além das implicaçóes que devem ser concretizadas no plano da reconfiguração dos novos cenários de aprendizagem digital.

\section{Referências}

AL-RAHMI, W.M.; OTHMAN, M.S. The impact of social media use on academic performance among university students: A pilot study. Journal of Information Systems Research and Innovation, n. 4, p. 1-10, 2013.

AMRY, A.B. The impact of WhatsApp mobile social learning on the achievement and attitudes of female students compared with face to face learning in the classroom. European Scientific Journal, v. 10, n. 22, p.116-136, 2014.

BAWA, N.; IBRAHIM, A.A. Using WhatsApp to extend learning into undergraduate students' digital lives: measuring its effects on academic performance in general studies. Journal of Science, Technology \& Education, v. 4, n. 2, p. 64-71, 2016.

BECKER, A. S. et al. NMC Horizon Report: 2017 Higher Education Edition. Austin, Texas: The New Media Consortium, 2017.

BOUHNIK, D.; DESHEN, M. WhatsApp goes to school: Mobile instant messaging between teachers and students. Journal of Information Technology Education: Research, n. 13, p. 217-231, 2014. 
BOTTENTUIT JUNIOR, J., ALBUQUERQUE, B.; COUTINHO, C. WHATSAPP e suas Aplicações na Educação: uma revisão sistemática da Literatura, EducaOnline, v. 10, n. 2, p. 67-87, 2016.

BROWN, J. S. Growing up digital: how the web changes work, education, and the ways people learn. United States Distance Learning Association Journal, v. 16, n. 2, 2002.

CHURCH, K.; OLIVEIRA, R. What's up with WhatsApp? Comparing Mobile Instant Messaging Behaviors with Traditional SMS. In M. ROHS \& A. SCHMIDT (Org.). MobileHCI '13 Proceedings of the 15th international conference on Humancomputer interaction with mobile devices and services. Munich (Germany), 2013. p 352-361. Disponível em: <https:// pdfs.semanticscholar.org/3ea1/9dcbe7c8fcde728f546d96543ae9e 2aa8d07.pdf>. Acesso em: 31 maio 2017.

\section{CONCEIÇÃO, S.S.; SCHNEIDER, H.N. WhatsApp} na educação superior: uma experiência de aprendizagem colaborativa. In: PIMENTEL, E.P.; CATTELAN, R.G. (Org.). In: CONGRESSO BRASILEIRO DE INFORMATICA NA ECUDAÇ AO. 5., 2016, Uberlândia. Anais..., Uberlândia: Universidade Federal de Uberlândia, 2016. p. 810-819. Disponível em: <http://br-ie.org/pub/index.php/wcbie/article/ view/7004>. Acesso em: 31 maio 2017.

DOWNES, S. Critical literacies and connectivism [Web log post]. 2010, July 5. Disponível em: <http://www.downes.ca/ post/53280>. Acesso em: 14 maio 2017.

DOWNES, S. Connectivism and connective knowledge [Web log post]. 2011, January 7. Disponível em: <http://www.downes. ca/post/54540>. Acesso em: 14 maio 2017.

GARRISON, D.; ANDERSON, T.; ARCHER, W. Critical 
Inquiry in a Text- Based Environment: Computer Conferencing in Higher Education. The Internet and Higher Education, v.2, n.2-3, p.87-105, 2000.

JENKINS, H. A Cultura da Convergência. São Paulo: Aleph, 2009.

MOREIRA, J. A.; ALMEIDA, A. C. How reliable and consistent is our learning community of inquiry? Psychometric qualities of the community of inquiry survey instrument applied to a sample of higher education Portuguese students. EduLearn 2011. International Conference on Education and New Learning Technologies $4^{\text {th }}-\sigma^{\text {th }}$ July, 2011 - Barcelona-Spain, 2011.

MOREIRA, J. A.; TRINDADE, S. D. O Dispositivo Digital Whats $A p p$ e o seu Impacto na Criação de Comunidades Virtuais de Aprendizagem. Interfaces Científicas: Educação, 2017. (no prelo).

MOREIRA, J. A.; TRINDADE, S. D. Reconfigurando Ambientes Virtuais de Aprendizagem com o WhatsApp. Informática na educação: teoria \& prática, 2017. (no prelo).

MOREIRA, J. A.; JANUÁRIO, S. Redes sociais e educação reflexôes acerca do Facebook enquanto espaço de aprendizagem. In: PORTO, C.; SANTOS, E. (Org.). Facebook e educaçáo: publicar, curtir, compartilhar. Campina Grande: EDUEPB, 2014. p. 68-84.

PRENSKY, M. Teaching digital natives: partnering for real learning. California: Corwin, 2010.

SELWYN, N. Social media in higher education. The Europa World of Learning. 2012, p.1-10. Disponível em: <http://www. 
educationarena.com/pdf/sample/sample-essay-selwyn.pdf>. Acesso em: 23 maio 2017.

SIEMENS, G. Knowing Knowledge. 2006. Disponível em: <http://www.elearnspace.org/KnowingKnowledge_LowRes.pdf>. Acesso em: 13 maio 2017.

SIEMENS, G. Learning ecology, communities, and networks - extending the classroom [Web log post]. 2003, October 17. Disponível em: <http://www.elearnspace.org/Articles/learning communities.htm>. Acesso em: 13 maio 2017.

TESS, P. The role of social media in higher education classes - a literature review. Computers in Human Behaviour, n. 29, p. A60-A68, 2013.

TRINDADE, S.D. O passado na ponta dos dedos: o mobile learning no ensino da História no $3^{\circ} \mathrm{CEB}$ e no Ensino Secundário. 2015. Tese (Doutorado) - Universidade de Coimbra, Coimbra, 2015.

TRINDADE, S.D.; RIBEIRO, A.I. Universidade de Coimbra digital: visitas de estudo guiadas por tablets. In: PEDRO, N. et al (Org.). Digital Technologies \& Future School - Atas do IV Congresso Internacional TIC e Educação 2016 (artigos selecionados). Lisboa: Instituto de Educação da Universidade de Lisboa, 2016. p. 179-188.

TRAXLER, J. Learning in a Mobile Age. International Journal of Mobile and Blended learning, v.1, n.1, 2009.

VEIGA, F. Estudo de um instrumento de autoconceito escolar: "Self-concept as a learner scale". In: GONÇALVES, M. et al. (Ed.). Avaliaçáo Psicológica: Formas e Contextos. Braga: APPORT, 1996. p. 365-380. 


\title{
O USO DO WHATSAPP COMO PRÁTICA SOCIOINTERACIONISTA E ESPAÇO DE APROXIMAÇÃO ENTRE SURDOS E OUVINTES
}

\author{
Huber Kline Guedes Lobato - UFPA \\ Rubens Alexandre de Oliveira Faro - UFPA \\ Renata Moraes de Oliveira - UFPA
}

\section{Reflexóes iniciais}

Desde o nascimento, os seres humanos sentem a necessidade de se relacionar com os outros, mas ainda não dominam a fala, dessa forma por meio da observação, do convívio e das interaçóes vivenciadas, aos poucos, desenvolvem o senso comunicativo, senso este, considerado básico para a vida em sociedade e para a efetivação de práticas sociointeracionistas.

Neste estudo nos deteremos na perspectiva sociointeracionista levantada por Lev Semenovitch Vygotsky (1896-1934), que foi um dos precursores e difusores da ideia de que o indivíduo se constitui como pessoa a partir das interaçóes sociais por ele vivenciadas e pela "mediação na interação homem-ambiente pelo uso de instrumentos, ao uso de signos" (VYGOTSKY, 1991, p. 11).

Vygotsky (1991) afirma ser própria da atividade humana a sociabilidade e que o intelecto se constrói a partir de experiências mediadas por fatores socioculturais externos e que estas, por sua vez, contribuem para o desenvolvimento individual. Desta forma, entendemos que o homem precisa manter contato com o outro 
para a própria constituição psicológica e, assim, constituir-se enquanto um sujeito social que age no mundo a partir do contato que tem com os outros indivíduos presentes na sociedade.

As observaçóes aqui apontadas são pertinentes à nossa pesquisa a fim de salientar que os indivíduos não se desenvolvem plenamente sem o contato com o outro e com as diferentes culturas, pois este contato contribui para o amadurecimento introspectivo do indivíduo. Para Vygotsky (1991, p. 11) "o mecanismo de mudança individual ao longo do desenvolvimento tem sua raiz na sociedade e na cultura”.

Compreendemos que as interaçóes sociais da atualidade podem ser mediadas por instrumentos e seus signos e que esta ideia se aproxima do que foi discutido por Vygotsky (1991, p. 27) ao pontuar que "nossa análise atribui à atividade simbólica uma função organizadora específica que invade o processo do uso de instrumentos e produz formas fundamentalmente novas de comportamento".

Vygotsky (1991, p. 30) reflete que "o uso de signos conduz os seres humanos a uma estrutura específica de comportamento que se destaca do desenvolvimento biológico e cria novas formas de processos psicológicos enraizados na cultura”. O que nos leva a inferir que ao adaptarem-se ao manuseio dos novos recursos tecnológicos e das novas ferramentas culturais, os indivíduos buscam com isso acompanhar as mudanças sociais e promover seu próprio desenvolvimento individual.

Atualmente, vivemos a chamada era digital, em que muitas mudanças acontecem diariamente no meio tecnológico e que está influenciando diretamente nas formas de interação social humana mediada por novos instrumentos sofisticados tecnologicamente. Assim é possível falarmos de interaçôes sociais presenciais ou virtuais que influenciam a vida dos indivíduos em um determinado contexto social.

Ao pontuarmos sobre as interações sociais presenciais nos referimos àquelas que acontecem face a face, em que trocamos contato visual, comumente nas conversas de cunho afetivo ou de caráter 
social com pessoas que estão presentes em nossa volta. Ao mencionarmos acerca das interaçóes sociais virtuais nos referimos àquelas que ocorrem em grupos de relacionamento por meio da internet e seus instrumentos como computadores e celulares ou por outros recursos tecnológicos como os aplicativos e plataformas interativas.

Sobre a ideia de interação social, ou a sociabilidade do homem com o seu entorno, na perspectiva vygotskyana, evidenciamos o pensamento de Ivic (2010, p. 16) ao analisar que "o ser humano, por sua origem e natureza, não pode nem existir nem conhecer $\mathrm{o}$ desenvolvimento próprio de sua espécie como uma mônada isolada: ele tem, necessariamente, seu prolongamento nos outros”.

Por conta da inserção maciça de recursos tecnológicos em seu cotidiano, os indivíduos, sem perceber, tomam para si novos hábitos e os agregam a sua rotina espontaneamente, como, por exemplo, a necessidade de verificar automaticamente as redes sociais ao acordar, checando os e-mails e respondendo rapidamente as mensagens curtas (SMS), por meio de aplicativo para a troca de mensagens.

Diante do imenso meio virtual, da variedade de recursos tecnológicos e da facilidade em manter contato mediante o uso de aplicativos de mensagens instantâneas, destacamos um dos mais recentes, que ganhou vários adeptos nos últimos anos: o WhatsApp - que é um aplicativo criado em 2009 para smartphones, uma plataforma interativa comunicativa.

Este aplicativo conta com uma variedade de serviços agregados, a criação de grupos de contatos a partir da agenda do próprio celular, possibilitando envio de vídeos, fotos, áudios, emojis, envio de documentos em vários formatos, realização de chamadas de áudio e vídeo-chamadas, utilizando uma conexão com a internet.

$\mathrm{O}$ Whats $A p p$ é um dispositivo de interação social virtual que também vem sendo utilizado como forma de aprendizagem em diversos âmbitos de nossa sociedade e por diversas pessoas, inclusive, pessoas surdas que utilizam tal dispositivo, visando realizar a interação social, tanto na Língua Brasileira de Sinais (LIBRAS) quanto 
na língua portuguesa, contribuindo para aproximação dos diversos grupos e indivíduos presentes em um contexto social.

As tecnologias são criadas com intuito de facilitar algo, contudo, a forma como são utilizadas dependerá de seus usuários. No caso dos aplicativos, certamente propicia um movimento social que pode gerar novas e diferentes perspectivas sociais que partem da viabilidade da interação social em nível pessoal à possibilidade de diferentes formas de aprendizagem ou novas formas de trabalho.

Com base nestes pressupostos, este estudo surgiu a partir da seguinte problemática: de que forma o aplicativo WhatsApp contribui na interação entre surdos e ouvintes? Como questóes norteadoras, elencamos as seguintes: Quais as percepções de participantes de um grupo de WhatsApp sobre a interação entre surdos e ouvintes? Quais as contribuiçóes do WhatsApp para aproximar o mundo de surdos ao mundo de ouvintes?

Desta maneira, temos como objetivo geral analisar a contribuição do WhatsApp na interação entre surdos e ouvintes. Como objetivos específicos, buscamos: apresentar o conceito de What$s A p p$ e os preceitos sociointeracionistas segundo a perspectiva $\mathrm{Vy}$ gotskyana; revelar as percepçóes de participantes de um grupo do WhatsApp sobre a interação entre surdos e ouvintes; e analisar a contribuição do aplicativo WhatsApp para aproximar o mundo de surdos ao mundo de ouvintes.

\section{Metodologia da pesquisa}

Em nosso estudo, utilizamos uma pesquisa de abordagem qualitativa, pois este tipo de pesquisa para Prodanov e Freitas (2013, p. 70):

Considera que há uma relação dinâmica entre o mundo real e o sujeito, isto é, um vínculo indissociável entre o mundo objetivo e a subjetividade do sujeito que não pode ser traduzido em números. 
A interpretação dos fenômenos e a atribuiçãa de significados são básicas no processo de pesquisa qualitativa.

Esta pesquisa é de caraterística netnográfica ou etnografia virtual, uma vez que esta tem sido usada para pesquisar redes sociais on-line que interagem por meio de diversas páginas na web. A netnografia ou etnografia virtual tem espaço assegurado nas pesquisas que se preocupam em saber o que as pessoas estão realmente fazendo mediante o uso da tecnologia. A netnografia ou etnografia virtual modifica a relaçáo espaço temporal e apresenta um contexto que é mediado pelas ferramentas, pelos ambientes, pelas práticas construídas no ciberespaço (HINE, 2000).

Os participantes da pesquisa são voluntários integrantes de um grupo de WhatsApp denominado "Ensine suas mãos a falar" criado em 22 de janeiro de 2015 pela administradora Renata Dutra. O referido grupo tem como objetivo trocar informaçóes e materiais relacionados à Libras e à educação de surdos. $\mathrm{O}$ grupo conta com a participação de 158 integrantes, entre eles surdos e ouvintes de todo o país.

No presente estudo, realizamos observaçóes das interaçóes no grupo de WhatsApp e fizemos entrevistas com 5 (cinco) participantes surdos e 5 (cinco) participantes ouvintes do referido grupo. Os nomes dos sujeitos foram substituídos pelas letras $(\mathrm{O})$ para os participantes ouvintes e $(\mathrm{S})$ para os surdos, seguido de uma numeração, com a finalidade de diferenciação dos participantes e para manter preservada a identidade (ID). Conforme detalhamos nos quadros que se seguem: 
Quadro 1 - Caracterização dos voluntários ouvintes

\begin{tabular}{|c|c|c|c|c|c|}
\hline ID & Gênero & Idade & Formaçáo & Localidade & $\begin{array}{c}\text { Conhece } \\
\text { Libras }\end{array}$ \\
\hline O-1 & F & 40 & $\begin{array}{c}\text { Graduada em } \\
\text { Pedagogia e } \\
\text { Especialista em Libras }\end{array}$ & Sáo Paulo & Fluente \\
\hline O-2 & F & 30 & $\begin{array}{c}\text { Graduada em Letras - } \\
\text { Português / Inglês e } \\
\text { Especialista em Libras }\end{array}$ & Espírito Santo & Fluente \\
\hline F-4 & M & 33 & $\begin{array}{c}\text { Graduada em } \\
\text { Pedagogia e } \\
\text { graduanda em Libras }\end{array}$ & Helo & Fluente \\
\hline O-5 & F & 30 & $\begin{array}{c}\text { Graduado em Letras } \\
\text { Inglês / } \\
\text { Intérprete de Libras }\end{array}$ & São Paulo & Fluente \\
\hline
\end{tabular}

Fonte: elaboração a partir dos dados da pesquisa (2017).

\section{Quadro 2 - Caracterização dos voluntários surdos}

\begin{tabular}{|l|c|c|c|c|c|}
\hline ID & Gênero & Idade & Formaçáo & Localidade & $\begin{array}{c}\text { Conhece } \\
\text { Libras }\end{array}$ \\
\hline S-1 & F & 48 & $\begin{array}{c}\text { Graduada em Letras - } \\
\text { Libras / Mestrado }\end{array}$ & Sáo Paulo & Fluente \\
\hline S-2 & M & 23 & $\begin{array}{c}\text { Graduado em Letras - } \\
\text { Português }\end{array}$ & Minas Gerais & Fluente \\
\hline S-3 & F & 59 & $\begin{array}{c}\text { Graduada em } \\
\text { Biblioteconomia / } \\
\text { Curso de Intérprete } \\
\text { (em andamento) }\end{array}$ & Bahia & Fluente \\
\hline S-4 & F & 35 & $\begin{array}{c}\text { Graduada em Pedagogia e } \\
\text { Especialista em Libras }\end{array}$ & Espírito Santo & Fluente \\
\hline S-5 & M & 56 & $\begin{array}{c}\text { Possui Ensino Médio / } \\
\text { Instrutor de Libras }\end{array}$ & Rio de Janeiro & Fluente \\
\hline
\end{tabular}

Fonte: elaboração a partir dos dados da pesquisa (2017). 
Os dados foram coletados por meio da aplicação de questionário e de roteiro semiestruturado por e-mails e conversas no WhatsApp, no período de 06/01 a 30/01/2017, respeitando a disponibilidade dos participantes para reenvio das respostas.

A seguir revelamos acerca das percepçóes dos participantes do grupo do WhatsApp sobre a interaçáo entre surdos e ouvintes; e analisamos a contribuição do aplicativo para aproximar o mundo de surdos ao mundo de ouvintes.

\section{WhatsApp: prática sociointeracionista e espaço de aproximaçáo entre surdos e ouvintes}

O grupo de WhatsApp "Ensine suas mãos a falar" efetivou, por meio deste aplicativo de mensagens, a concretização de práticas sociointeracionistas necessárias para responder a perguntas e dúvidas relacionadas a sinais, em Libras, utilizando apenas um recurso tecnológico que disponibiliza diferentes materiais, em PDF, JPEG e vídeos, de forma rápida e prática, proporcionando a aproximação e interação entre os integrantes do grupo.

Assim, uma das indagaçóes que permeou nossa pesquisa foi a seguinte: por meio da internet é fácil conhecer novos amigos? As respostas foram unânimes, pois todos consideraram ser fácil conhecer novos amigos pela internet, sendo assim, apresentamos apenas o posicionamento de $\mathrm{O}-5$ que diz:

A internet tem ajudado muito na busca de conhecimentos, como também de fazer novos contatos, por exemplo, eu trabalho vendendo livros de Libras, camisetas e etc, e a maioria por meio de Facebook e WhatsApp, conheço pessoas de vários estados virtualmente (dados enviados no dia 16/01/2017) ${ }^{1}$.

1 Como forma de referenciar os dados, informaremos a data individual de recebimentos dos dados da pesquisa. 
Conhecer pessoas por meio de recursos tecnológicos é uma das mais novas formas de interação social da atualidade, que propicia tanto aos surdos, quanto aos ouvintes, integração ao meio social mediante as novas ferramentas culturais; isso tudo vai modificando as interaçóes sociais presenciais em interaçôes sociais virtuais.

Do ponto de vista dos surdos o uso do computador e da Internet inaugurou uma nova dimensão às suas possibilidades de comunicaçáo, pois são tecnologias acessíveis visualmente. Se, para os ouvintes, elas abriram perspectivas que levaram a modificaçóes profundas nos usos e costumes de toda a sociedade, para os surdos, essas mudanças podem ser ainda mais significativas, (STUMPF, 2010, p. 2).

Esse tipo de interação social mediada pelo computador e/ou smartphones vinculados às redes sociais ou aos aplicativos proporciona a seus usuários o contato com diferentes línguas e culturas, tanto a língua portuguesa presente nas mensagens de textos, como o uso da Libras por meio de vídeos entre os conhecedores dessa língua. A frequência do uso desses aplicativos, em particular o What$s A p p$, contribui para a internalização de diferentes elementos, sinais gráficos ou sinais visuoespaciais em Libras.

Os participantes foram solicitados a comentar sobre o seguinte questionamento: quais aprendizados obtiveram por meio do WhatsApp?

Assim, S-1 mencionou que "de tudo o que se passa, mas eu aprendo a escrever e as vezes ajudo também Libras" (dados enviados no dia 10/01/2017). Esse fato foi repetido por grande maioria dos entrevistados, que reconheceram ter aprendido sobre os mais variados assuntos por meio das trocas de mensagens, em especial relataram ter aprendido muitos sinais em Libras que antes desconheciam. 
Essa troca de conhecimentos é considerada por Stumpf (2010, p. 5) uma forma de inserção comunicativa dos surdos ao meio tecnológico:

Para os surdos as modificaçóes trazidas pelas novas tecnologias não foram apenas educativas sociais e laborais, mas, sobretudo de inserção comunicativa em muitas das atividades de vida diárias antes inacessíveis, pois, a distância e o tempo se encurtam pela Internet e surgiram novas maneiras de se relacionar.

Para os surdos, tão relevante quanto interagir é sentir-se integrado e incluído socialmente, alguns dos voluntários assinalaram que o aplicativo favorece esse processo de integração ao propiciar condiçôes de interação social, respeitando as especificidades oriundas da surdez. Desta forma, reiteramos sobre os preceitos vygotskyanos de que "todas as funçôes originam-se das relações reais entre indivíduos” (VYGOTSKY, 1998, p. 75).

Consideramos que se funçôes superiores se desenvolvem a partir das dialógicas relaçóes reais, mesmo as mediadas por smartphones ou computadores podem propiciar desenvolvimento cognitivo em quem os manuseia. Assim, Koll (2010, p. 97) pontua que:

a atividade psicológica interna do indivíduo tem sua origem na atividade externa [...] a atividade é uma relaçáo homem-mundo, que envolve finalidades conscientes e atuação coletiva e cooperativa. A atividade é realizada por meio de açóes dirigidas por metas, desempenhado pelos diversos indivíduos envolvidos na atividade.

Relacionamos neste sentido a finalidade consciente, ou seja, as trocas de mensagens entre os participantes do grupo do WhatsA$p p$ que, até em diferentes localizaçóes geográficas, demonstram que essas mensagens têm o intuito de suprir uma finalidade social, pes- 
soal e informativa, a partir do conhecimento de mundo do outro e relacionando ao seu próprio mundo; isto constitui-se uma ação eminentemente social.

A frequência com que os voluntários da pesquisa mantêm contato com pessoas surdas/ouvintes pelo WhatsApp também foi uma das indagaçôes apresentadas na pesquisa. Com isso apresentamos a resposta de $\mathrm{O}-2$ :

Frequentemente converso com os amigos surdos pelo Whats App, todos os dias praticamente. Alguns são mais íntimos, por exemplo, com aluno que já fui intérprete, nossa interação é diferente, pois já fiz parte do dia a dia dele, entáo conversamos sobre tudo. Conversamos sobre as férias, trocamos sinais. E agora que estou fazendo parte de um grupo no Whats $A p p$, no qual interajo com pessoas de várias regiôes, sempre que tem novidade, eu compartilho com ele (dados enviados no dia 10/01/2017).

O uso do WhatsApp se constitui enquanto um meio de efetivar a aproximação entre surdos e ouvintes, sendo que seu uso inspira intimidade e diálogos sobre assuntos da vida cotidiana, que irá refletir na geração de outros conhecimentos para todos os participantes do grupo, neste caso, surdos e ouvintes.

Apresentamos o posicionamento de S-2: “Tenho vários grupos de estudos de vários temas e nestes grupos trocamos muita informação e com isso possibilita o desenvolvimento" (dados enviados no dia 12/01/2017). O que S-2 compreende por desenvolvimento seria o que Koll (2010, p. 81) nos apresenta como aprendizado, pois

o desenvolvimento da espécie humana e do indivíduo dessa espécie está, pois, baseado no aprendizado, que, para Vygotsky, sempre envolve interferência direta ou indireta, de outros indivíduos e a reconstrução pessoal da experiência e dos significados. 
Quando indagados se o aplicativo WhatsApp facilita a interação social entre surdos e ouvintes, as respostas foram que este aplicativo facilita a interação social, mas que o contato presencial não pode ser descartado. Como enfatiza O-3: "Ajuda por ter chamadas de vídeo e devido as pessoas terem um tempo 'curto' devido à correria do dia a dia, mas vc estar presente com a pessoa faz toda a diferença" (dados enviados dia 10/01/2017).

S-2 revela que "Sim, pois posso conversar com quem não sabe Libras em português" (dados enviados dia 12/01/2017). A recorrência das respostas de que o aplicativo facilitaria esta socialização entre surdos e ouvintes nos leva a considerar como uma nova forma de se relacionar mediada.

Essa concepção de que é o aprendizado que possibilita o despertar de processos internos do indivíduo liga o desenvolvimento da pessoa a sua relação com o ambiente sociocultural em que vive e sua situação de organismo que não se desenvolve plenamente sem o suporte de outros indivíduos de sua espécie (KOLL, 2010, p. 60).

Para que ocorra um real desenvolvimento pessoal é necessário que estes indivíduos disponham de diferentes contextos sociais e que nesses contextos apliquem de forma autônoma, seja por meio de mensagens escritas, ou de vídeos e/ou em contexto presenciais, esses novos aprendizados adquiridos e partilhados uns com os outros.

Neste sentido, visando saber o que já fora assimilado por meio do uso desse aplicativo, perguntamos: a participação no grupo de WhatsApp havia modificado algo no cotidiano de cada participante? As respostas evidenciaram mudanças relevantes, conforme veremos nos fragmentos a seguir: 
O-1: $\mathrm{O}$ aplicativo me aproximou de pessoas que jamais imaginaria conhecer (Dados enviados dia 10/01/2017).

O-4: Possibilitou que meus alunos surdos entre em contato para tirar dúvidas. Entre aspas, em parte encurtou a distância e viabilizou a comunicação, porém, tirou o tête-à-tête (Dados enviados dia 30/01/2017).

O-5: Com surdos é visual; pelo App os surdos podem conversar ao vivo com ouvintes tranquilamente (Dados enviados dia 16/01/2017).

S-2: Claro! Eu trabalho hoje com o WhatsApp (Dados enviados dia 12/01/2017).

S-3: Sim, mudou. Posso avisar o grupo de irmãos sobre meus atos. Com amigos podemos combinar eventos e encontros (Dados enviados dia 12/01/2017).

S-4: Facilitou muito né, por eu n ouvir, qd preciso falar com alguém, utilizo o zap (Dados enviados dia 14/01/2017).

S-5: Sim mudou muito para melhor (Dados enviados dia 09/01/2017).

Assim, percebemos que o uso do aplicativo WhatsApp propicia um mecanismo mais equitativo para que surdos e ouvintes mantenham uma aproximaçấo com seus familiares e amigos, pois com o uso do Whats $A p p$ o contato entre as pessoas se torna mais rápido e a distância se encurta, para que assim a comunicaçáo seja viabilizada. Por meio do aplicativo é possível conversar, trabalhar, fazer amizades e estreitar as relaçóes entre as pessoas.

Assim, é impossível pensar o ser humano privado do contato com outro grupo cultural, o qual lhe fornecerá os instrumentos e signos que possibilitaráo o desenvolvimento das atividades psicológicas mediadas, tipicamente humanas (KOLL, 2010).

Dessa forma podemos considerar que as interaçóes sociais e pessoais promovem mudanças internas e que o aplicativo Whats $A p p$ vem contribuindo na aproximaçáo da realidade surda ao contexto 
ouvinte e com isso possibilita diferentes maneiras de aprendizado, por meio da interação social e integra e/ou inclui surdos e ouvintes a um mesmo espaço social real ou virtual, fazendo com que ambos realizem o aprendizado continuamente.

Neste sentido, Vygotsky (1991, p. 61) revela que

o aprendizado adequadamente organizado resulta em desenvolvimento mental e póe em movimento vários processos de desenvolvimento que, de outra forma, seriam impossíveis de acontecer. Assim, o aprendizado é um aspecto necessário e universal do processo de desenvolvimento das funções psicológicas culturalmente organizadas e especificamente humanas.

Desta maneira, pontuamos acerca da relevância do aplicativo WhatsApp para aproximar o mundo de surdos ao mundo de ouvintes, pois percebemos que o referido grupo, com surdos e ouvintes, interagindo cotidianamente, faz com que ambos aprendam continuamente, uma vez que os surdos aprendem com os ouvintes a forma escrita da língua portuguesa e os ouvintes aprendem com os surdos os sinais em Libras que são divulgados no grupo do WhatsApp denominado "Ensine suas mãos a falar".

$\mathrm{O}$ uso do WhatsApp entre surdos e ouvintes cumpre com uma função de interação social. Assim, Ivic (2010, p. 16-17) pontua que "é precisamente o ponto essencial da concepção vygotskyana de interação social que desempenha um papel construtivo no desenvolvimento"; com isso, o uso do aplicativo vem contribuir com a forma de comunicação e interação entre surdos e ouvintes, mas que "há também uma interação com os produtos da cultura" (IVIC, 2010, p. 19) neste caso, os diferentes instrumentos e técnicas (incluindo o Whats $A p p$ ) presentes em nossa sociedade.

Então, esta ferramenta de interação on-line, que é o WhatsApp, possibilita o aprendizado, sendo também um meio de co- 
municação entre surdos e ouvintes. Foi isto que se verificou nesta pesquisa, ou seja, percebemos um envolvimento mais espontâneo com um recurso tecnológico que faz parte do cotidiano dos participantes do grupo de WhatsApp.

Os resultados deste estudo revelam que o WhatsApp contribui na interação entre surdos e ouvintes; os participantes partilham informaçóes e conhecimentos por meio do WhatsApp; e o uso do $A p p$ propicia, de forma equânime, condiçóes de interação entre surdos e ouvintes.

\section{Em suma...}

Esta pesquisa analisou as interaçóes mediadas pelo aplicativo WhatsApp entre surdos e ouvintes sob a perspectiva sociointeracionista vygotskyana. Tivemos como objetivo analisar a contribuição do WhatsApp na interação entre surdos e ouvintes. Diante dos resultados da pesquisa, verificou-se que o contato entre surdos e ouvintes por meio do aplicativo já é visto por seus usuários como instrumento significativo de interação social.

Também é relevante ressaltar que o WhatsApp é utilizado pelos participantes, tanto para a aproximação de contatos pessoais, como para contato profissional, pois alguns dos integrantes, utilizam o WhatsApp como forma de socializar materiais sobre surdez e Libras.

Segundo os entrevistados, o uso do aplicativo propicia mais facilidade na execução de tarefas cotidianas, como avisar sobre a localização a familiares, marcar encontros com amigos ou mesmo por possibilitar a interação social entre diferentes públicos, surdo ou ouvinte, seja de caráter pessoal ou profissional.

Conclui-se que o uso do WhatsApp, como prática sociointeracionista, é um espaço de aproximação entre surdos e ouvintes que contribui com o uso e difusão da Língua Brasileira de Sinais (LIBRAS) e da Língua Portuguesa em sua modalidade escrita, seja por meio de chamadas de vídeos ou mensagens de textos. 
Diante dos resultados deste estudo, consideramos que o aplicativo contribui para aproximaçáo de surdos e ouvintes, propicia a integração e inclusão de pessoas surdas e ainda permite que seus membros possam socializar e debater sobre as especificidades das diferentes culturas. Assim, ressaltamos a necessidade de direcionar mais pesquisas de modo a investigar as possibilidades de ensino e aprendizagem entre surdos e ouvintes por meio do aplicativo WhatsApp no contexto educativo.

\section{Referências}

HINE, Christine. Virtual Ethnography. London: SAGE Publications, 2000.

IVIC, Ivan. Lev Semionovich Vygotsky. Recife: Fundação Joaquim Nabuco; Massangana, 2010.

KOLL, Marta de Oliveira. Vygotsky: Aprendizado e desenvolvimento: um processo sócio-histórico. São Paulo: Scipione, 2010.

PRODANOV, Cleber Cristiano; FREITAS, Ernani Cesar de. Metodologia do trabalho científico: métodos e técnicas da pesquisa e do trabalho acadêmico. 2. ed. Novo Hamburgo: Feevale, 2013.

STUMPF, Marianne Rossi. Educação de Surdos e Novas Tecnologias. Florianópolis, 2010. Disponível em: <http://www. libras.ufsc.br/colecaoLetrasLibras/eixoFormacaoPedagogico/ educacaoDeSurdosENovasTecnologias/assets/719/ TextoEduTecnologia1_Texto_base_Atualizado_1_.pdf >. Acesso em: 17 maio 2017. 
VYGOTSKY, Lev Semenovitch. Pensamento e linguagem. 2. ed. São Paulo: Martins Fontes, 1998.

VYGOTSKY, Lev Semenovitch. A formação social da mente.

São Paulo: Martins Fontes, 1991. 


\section{TEMA 2 \\ WHATSAPP E PROCESSOS EDUCATIVOS}




\title{
INTERAÇÓES NO CIBERESPAÇO: ESTUDOS E PESQUISAS SOBRE O WHATSAPP NA EDUCAÇÃO NO BRASIL E PORTUGAL
}

\author{
Ronaldo Nunes Linhares - UNIT \\ Alexandre Meneses Chagas - UNIT \\ Elbênia Marla Ramos Silva - UA
}

\section{Introdução}

O crescente desenvolvimento das tecnologias digitais vem transformando os hábitos e inserindo diferentes formas de comunicar e de fazer comunicaçáo. Vivemos numa era digital em que, quando menos esperamos, somos surpreendidos por um novo objeto e uma nova tecnologia que provoca impactos significativos nos mais diversos âmbitos sociais.

Para Okada (2008), a nova cena sociotécnica de informaçáo e comunicaçáo se caracteriza por uma nova forma de materializaçáo. A autora chama atençáa para as transformaçóes provenientes das mudanças na forma e nos suportes para a produção e circulação de informaçáo que passaram dos mediadores analógicos e atômicos para os bit, códigos digitais universais. Tal qual a escrita, produzida e divulgada em suportes e códigos dialógicos, os novos códigos e formas de registro e publicização criam novas formas de socialização dessa mesma informação. A associação da informática com as telecomunicaçôes possibilita a emergência de uma revolução digital. 
Ao considerar, entre outras coisas, o papel da informação no processo de socialização, subjetivação e humanização; a importância da comunicação e suas formas no ecossistema educativo, formal ou informal; o fortalecimento e ampliação das possibilidades da "Rede" digital como via de socialização na cibersociedade e a transformação da informação em mercadoria numa sociedade de capitalismo globalizado fortaleceram e universalizaram as transformaçóes provocadas pela emergência dos "novos códigos digitais universais", Okada (2008, p. 3), observa que,

digitalizada, a informação se reproduz, circula, modifica e se atualiza em diferentes interfaces. É possível digitalizar sons, imagens, gráficos, textos, enfim uma infinidade de informaçóes. [...] Novos processos criativos podem ser potencializados pelos fluxos sócio-técnicos de ambientes virtuais de aprendizagens que utilizam o digital como suporte.

Para uma sociedade de consumo é fundamental acompanhar a demanda por novos suportes e dispositivos tecnológicos, novos programas, softwares, aplicativos e ambientes de aprendizagem que interligam os sujeitos à informação mediada por meios de comunicação em redes que, do local, se expandem no processo de virtualização para o global. O virtual, entendido como potência, "vir a ser", define a natureza das relaçóes abertas, colaborativas, interativas, hipertextuais e multimidiáticas que, mediadas por suportes e dispositivos sociotécnicos digitais e de comunicaçáo móvel, modificam os processos de aprendizagem a partir de novas formas de comunicaçóes interpessoais, sua vinculação com o consumo de conteúdo, socialização, produção, veiculação e publicação de conteúdo.

Este artigo tem como propósito identificar os estudos sobre as práticas de uso do WhatsApp na educação brasileira e portu- 
guesa. É certo que este tema ainda é novo, mas consideramos as transformaçôes que os dispositivos e plataformas móveis têm proporcionado na sociedade.

\section{M-Learning: redes sociais e aprendizagem via aplica- tivos comunicacionais}

Quando Dewey escreveu o livro Democracia e Educação a sociedade de seu tempo estava passando por uma ruptura de cunho social e tecnológica, com a utilizaçáo das estradas asfaltadas, permitindo longas viagens de grupos maiores de pessoas, a comunicação sem fio que transpassava o atlântico, permitindo uma ampliaçáo da comunicação mundial. Se considerarmos o desenvolvimento das infovias digitais, a colocação de Dewey permanece atual, pois estamos vivenciando uma nova ruptura social e tecnológica, agora com a internet e as tecnologias móveis. Sendo que os ditos "canais para a distribuiçấo de mudanças" hoje fazem parte da nossa vida diária e levamos para todos os lugares (SHARPLES; TAYLOR; VAVOULA, 2007), ou seja, vivemos e vivenciamos "Uma sociedade que é móvel, que é cheia de canais para a distribuição de mudanças ocorrendo em qualquer lugar, deve assegurar que seus membros sejam educados para a iniciativa pessoal e adaptabilidade" (DEWEY, 1936, p. 188) ${ }^{1}$.

É muito comum ao pensar sobre a aprendizagem móvel (m-learning) relacionar apenas ao dispositivo, principalmente o celular, mas devemos deixar claro que o dispositivo é apenas o meio para possibilitar uma mobilidade do aluno durante o seu processo de aprendizagem. Essa mobilidade deve ir além das premissas básicas da comunicação com o professor, o colega e de acesso ao con-

1 "A society which is mobile, which is full of channels for the distribution of a change occurring anywhere, must see to it that its members are educated to personal initiative and adaptability" (DEWEY, 1936, p. 88). 
teúdo, claro que como dito, são premissas básicas para contribuir com a mobilidade do aluno. Mas, qual a situação da utilização por parte dos alunos em relação aos dispositivos móveis?

Com base na pesquisa Tic Domicílio de 2015, o percentual de usuários que utilizam o celular como forma de acessar a internet demonstra o potencial do m-learning, em média 90\% dos entrevistados utilizam o celular para acessar a internet, sendo: 95\% Região Norte; 93\% Região Centro-Oeste; 90\% Regiáo Nordeste; 89\% Sudeste e $85 \%$ Região Sul. Filtrando por faixa etária que compreende a média do aluno de cursos superiores de 16 a 34 anos essa média de acesso aumenta para 95,5\%. Deste público (16 a 34 anos), $49,5 \%$ realizaram atividades ou pesquisas acadêmicas e $44 \%$ estudaram por conta própria, utilizando a internet.

Diante destes dados, podemos observar que ainda temos muitos alunos para motivar no uso dos dispositivos móveis para ampliar sua aprendizagem. Estes dispositivos ampliam as possibilidades de contato do aluno com diversos contextos e narrativas. Numa visão da aprendizagem móvel com base no contexto, Mike Sharples, Taylor e Vavoula (2007) afirmam que a característica da aprendizagem está no processo de conhecer por meio de conversas entre vários contextos, acontecendo entre pessoas e tecnologias interativas.

Há de se concordar que os dispositivos móveis atuais, as pessoas e as conexóes sem fio, são responsáveis por uma transformação nas formas de aprender, no surgimento de novas profissóes, novas linguagens, novas formas de se comercializar produtos e principalmente serviços e estas mudanças aceleradas alteram os contextos continuamente (TRAXLER, 2009). Numa visão comparativa do impacto dos dispositivos digitais móveis no processo de comunicação na atualidade, Aguado, Feijóo e Martinéz (2013) observam que para alcançar uma audiência de 50 milhóes de consumidores, o rádio levou 38 anos, a televisão levou 14, a internet 4 anos para conectar o mesmo número de usuários, o primeiro smartphone levou apenas dois anos para vender 50 milhóes de aparelhos. 
Ainda com base na perspectiva do contexto, Koole (2009) apresenta uma visão holística para a aprendizagem móvel, em que ela é uma convergência das interaçôes dos alunos (ou aprendentes), com seus dispositivos e com a sociedade (outras pessoas). No qual aborda os aspectos do dispositivo, do aluno e do social para uma boa aprendizagem móvel.

Os aspectos dos dispositivos compreendem: 1 - características físicas: como impacta no uso do dispositivo ao se mover; 2 - capacidade de entrada: permite conectar dispositivos para entrada de dados, como teclado etc.; 3 - capacidade de saída: permite a saída de dados, para um projetor etc.; 4 - capacidade de armazenamento: possibilidade de armazenamento do dispositivo para aplicativos e dados a serem utilizados; 5 - velocidade de processamento: é suficiente para atender a necessidade do usuário; 6 - taxa de erros: os usuários podem não ser capazes de executar as tarefas desejadas e podem perder confiança no dispositivo (KOOLE, 2009)

Já os aspectos do usuário são: 1 - conhecimento prévio: afeta positivamente o aluno em compreender novos conceito, em aceitar novos modelos de conteúdos; 2 - memória: o uso de elementos multimídia trabalha diversos estímulos, podendo ajudar os alunos a entender e reter conceitos mais facilmente; 3 - contexto e transferência: utilizar metodologias ativas no auxílio à informação para que os alunos lembrem, compreendam e transfiram conceitos para contextos variados; 4 - descoberta aprendendo: pode estimular o aluno a desenvolver habilidades para "filtrar, escolher e reconhecer" informaçôes relevantes em diferentes situaçôes; 5 - emoçóes e motivaçóes: a disposição de um aluno e/ou motivação para a realização de determinada tarefa (KOOLE, 2009).

Nos Aspectos Sociais, temos: 1 - Conversação e Cooperação: afeta a qualidade e a quantidade de comunicação, podem ocorrer falhas de comunicação quando nenhuma das 4 máximas (quantidade, qualidade, relação e maneira) não for cumprida; 2 - Interação Social: conversa como atividade cooperativa, compartilhamento 
de sinais e símbolos para contribuir na compreensão das crenças e comportamentos sociais e culturais (KOOLE, 2009).

Após as convergências destes aspectos, Koole (2009) entende que acontece o processo de aprendizagem móvel, proporcionando uma colaboração entre os envolvidos, um acesso à informação de forma adequada e uma contextualização da aprendizagem por parte dos alunos. "[...] a aprendizagem móvel efetiva pode capacitar os alunos, permitindo-lhes avaliar e selecionar informaçóes relevantes, redefinir seus objetivos e reconsiderar sua compreensão de conceitos [...]"2 (KOOLE, 2009, p. 38).

Sendo assim, torna-se necessário observar: a mediação - a natureza da própria interação muda como aprendentes, eles interagem uns com os outros, seus ambientes, ferramentas e informaçóes; o acesso e seleção de informaçóes - à medida que a quantidade de informaçôes disponíveis aumenta, os alunos devem aumentar seus esforços para reconhecer e avaliar a adequação e precisão das informaçôes e a navegação do conhecimento - na produção do conhecimento, os professores determinam o que e como a informação deve ser aprendida. Na navegação do conhecimento, os alunos adquirem habilidades para selecionar, manipular e aplicar informaçóes adequadamente às suas próprias situaçóes e necessidades específicas. Desta forma pode-se desenvolver um ambiente móvel cognitivo (KOOLE, 2009).

\section{Cibercultura e os dispositivos de rede: funçóes e ca- racterísticas dos aplicativos de comunicaçáo do sms ao aplicativo WhatsApp}

Após quase 20 anos de experiência no Yahoo, Jan Koum e Brian Acton, em 2009, lançam o aplicativo WhatsApp, que ini-

2 "[...] effective mobile learning can empower learners by enabling them to better assess and select relevant information, redefine their goals, and reconsider their understanding of concepts [...]" (KOOLE, p. 38, 2009). 
cialmente tinha a função apenas de mostrar o status do usuário, se estava disponível, ocupado, no trabalho, na escola entre outros status. Sim, ele só mostrava o seu status, você entrava e via o status dos amigos. Mas ainda em 2009, resolveram modificar a funcionalidade do aplicativo, tornando possível o envio de mensagens de texto, sendo assim uma alternativa a opção do Short Message Service (SMS). Sendo assim, o WhatsApp é classificado como um aplicativo de mensagem instantânea, esta característica torna a troca de mensagens rápidas, muitas das vezes acontecendo quase em tempo real (WHATSAPP, 2017).

Do seu lançamento em 2009 até os dias atuais, o aplicativo passou por várias modificaçóes e ampliaçóes de seus serviços, muitos deles por solicitação dos usuários. A seguir, com base nas informaçóes disponibilizadas no Blog Whatsapp (2017), blog oficial da empresa, seguem algumas destas evoluçóes. Em 2011, é implementado o grupo no WhatsApp, sendo possível juntar pessoas para compartilhar mensagens em comum e, em 2012, foi disponibilizada a opção de modificar o ícone do grupo e de enviar a localização em que está como forma de mensagem, sendo possível abrir outro aplicativo de mapa para saber onde fica a localidade enviada.

A possibilidade das mensagens de voz é disponibilizada em 2013, sendo apenas necessário clicar no microfone e falar a mensagem. Quem recebe a mensagem de voz, pode notar que antes de ouvir o status do microfone é verde, após ouvir ele modifica para azul e modifica também para quem enviou. Em 2014, o WhatsApp, após sua aquisição pelo Facebook, recebeu investimento para novos desenvolvimentos como poderemos perceber a seguir.

Em 2015, a versão do WhatsApp para o navegador é disponibilizada. Para continuar ativo na versão web, o celular deve estar conectado na internet. As mensagens são replicadas, ou seja, continuam no celular. Também nesse ano disponibiliza a chamada de voz pelo aplicativo, tornando possível substituir a ligação telefônica por uma chamada de voz pelo WhatsApp. 
Durante o ano de 2016, foram disponibilizadas outras funcionalidades, dentre elas: a segurança, com criptografia de ponta a ponta, do envio ao recebimento, deixando as mensagens seguras para os seus usuários. Essa implementação garante o sigilo das mensagens trocadas; a opção de envio de arquivos com até $100 \mathrm{Mb}$; a versão para desktop, ou seja, para baixar e instalar no computador; a possibilidade de editar e melhorar as fotos e vídeos sejam eles produzidos no aplicativo ou que já possua no seu dispositivo e, finalmente, em novembro, foi disponibilizada a opção de chamada de vídeo, por identificar uma necessidade apontada pelos usuários, pois nem sempre os textos, áudios ou vídeos são suficientes para um contato mais profundo, como conversar e ver uma pessoa em tempo real.

Um estudo encomendado pelo WhatsApp ao Analysis Group em 2016, e publicado em 2017, demonstra o impacto que o aplicativo tem na relação dos usuários com empresas, sendo assim, impactando na atividade econômica de uma localidade. Este estudo foi realizado com usuários de países como Brasil, Índia, Alemanha e Espanha, sendo 750 usuários por país, assim distribuídos: 300 em grupos de consumidores e 450 em grupos de pequenas empresas. A pesquisa utilizou grupos focais, pesquisas nacionais representativas e econométricas. Esse estudo serve para demonstrar o real impacto que o WhatsApp possui em nossa sociedade.

A apresentação de dados sobre a internet é muito volátil, pois a velocidade na qual as transformaçóes acontecem mudam em questão de instantes. Antes que termine de ler esta informação os dados já se alteraram, mas se torna necessário expô-los para uma construção de cenário em torno do aplicativo. Em outubro de 2016, o WhatsApp possuía no Brasil mais de 100.000.000 de usuários ativos, o que representava 49\% da população brasileira (205.823.665, estimada em 2016) utilizando o aplicativo (ANALYSIS GROUP, 2017)

Estima-se que foi movimentada com a ajuda do aplicativo, em 2016, uma quantia em torno de 2,9 bilhóes de dólares, apenas no Brasil. Dentre os entrevistados, a maioria (42\%) realiza de 7 a 
9 compras com o uso do WhatsApp semanalmente, ver Tabela 1, o que fortalece a relação do uso do aplicativo no impacto econômico que gera.

Tabela 1 - Quantidade de transaçóes realizadas por meio do WhatsApp em 2016

\begin{tabular}{c|c}
\hline $1-3$ compras & $22 \%$ \\
\hline $4-6$ compras & $24 \%$ \\
\hline $7-9$ compras & $42 \%$ \\
\hline 10 compras & $10 \%$ \\
\hline Não sabe informar & $2 \%$ \\
\hline
\end{tabular}

Fonte: ANALYSIS GROUP. Whatsapp economic impact infographics (2017).

Dentre os concorrentes, a pesquisa identificou que o What$s A p p$ é o mais utilizado no Brasil, quando falamos de aplicativo de mensagens instantâneas. Entre os pesquisados quais os serviços eles mais utilizam: 74,9\% WhatsApp; 61,4\% Facebook Messenger; 22,8\% Skype; 8,2\% Google Hangout, 7,1\% Telegram; 6,8\% iMessage e outros com menos de $5 \%$ cada um.

Tabela 2 - Organizaçóes que mantêm contato via WhatsApp

\begin{tabular}{l|r}
\hline Escolas/Universidades/bibliotecas & $59 \%$ \\
\hline Comunidade / centros de atividades & $21 \%$ \\
\hline Governo/órgão de trânsito & $18 \%$ \\
\hline Centro religioso & $30 \%$ \\
\hline Outros & $9 \%$ \\
\hline Nenhuma das acima & $7 \%$ \\
\hline Não sabe informar & $1 \%$ \\
\hline
\end{tabular}

Fonte: ANALYSIS GROUP. Whatsapp economic impact infographics (2017). 
Quando questionado com quais tipos de organizaçôes eles mantêm contato via WhatsApp, a maioria utiliza para se comunicar com organizaçôes educacionais, como pode-se observar na Tabela 2, desta forma estas instituiçóes já possuem um vínculo com seus alunos relativamente grande, sendo possível direcioná-los para o uso educacional e não apenas para questóes comerciais como demonstrado na pesquisa.

\section{WhatsApp e educação: mapeando os estudos e pesquisas em construçáo no Brasil e em Portugal}

A preocupação aqui não é construir uma análise comparada sobre os dados referentes às duas realidades. Nosso intuito é identificar se e como o aplicativo WhatsApp, como um dos mais utilizados aplicativos digitais de rede de comunicação social já são considerados como objeto de estudos e pesquisas no campo da educação no Brasil e em Portugal, em seguida mapear essa produção e caracterizá-la a partir de sua origem, objetivos, metodologia e resultados. A escolha dos países considera as aproximações históricas das políticas públicas de inserção das Tecnologias digitais de informação e comunicação (TDIC) na educação desses países e aporte de seus autores e as possibilidades de ampliar esse olhar para outra realidade de língua portuguesa.

Para tanto, inicialmente levantamos duas ponderaçóes. Primeiro, em relação a inovação do tema. Apesar de com menos de uma década, consideramos o impacto desse aplicativo nas relaçóes comunicacionais, na telefonia e no processo de socializaçáo no ciberespaço. Cabe aqui retomar Aguado, Feijóo e Martinéz (2013, p. 16), quando observam para os dispositivos móveis "não é só uma nova forma de aproveitar os cenários e ritos de consumo até então. Se trata de um novo meio dotado de um ecossistema próprio, no sentido de atores definidos e relaçóes características entre esses atores". Em seguida, consideramos alguns estudos que atestam a 
resistência de uso dos dispositivos móveis em sala e nos processos de ensino e aprendizagem.

Em Portugal, a integração do uso de tecnologias digitais na educação já ocorre há muitos anos e são impulsionadas por políticas de âmbito nacional nas escolas e universidades do país. Muitos projetos responsáveis por esta integração da TDIC e da internet no ensino escolar e superior foram propostos e implantados pelo $\mathrm{Mi}$ nistério da Educação. São 32 anos de caminhada com políticas que envolveram diferentes tecnologias digitais para uso na educaçáo.

Dentre as políticas estão: Projeto Minerva, ou seja, Meios informáticos no Ensino: Racionalização, Valorização, teve início em 1985 com o objetivo da inserção da Tecnologia de Informação e Comunicação (TIC) nas escolas, entretanto foi lançado em 1996 o projeto Nónio-Século XXI que perdurou até 2002, o próximo Projeto foi o uARTE - Internet na Escolas em 1997 e ficou em vigor até 2003. Em seguida, o Edutic criado pelo Gabinete de Informação e Avaliação do Sistema Educativo (GIASE) que tinha como objetivo dar continuidade ao projeto Nónio - Século XXI. Em 2005 surgiu a equipe de missão Computadores, Redes e Internet da Escola (CRIE) com objetivo de fazer as instalaçóes de computadores e internet nas Escolas.

Até ser elaborada, a maior política de modernização tecnológica do Ministério da Educação elaborada em 2007, denominada "Plano Tecnológico da Educaçáa" (PTE), teve como objetivo colocar Portugal entre os cinco países da Europa com maior modernização tecnológica das escolas até o ano de 2010. Em continuação, criou-se o projeto Internet Segura também em 2007 (ainda em vigor) com o objetivo de conscientizar a sociedade para os riscos associados ao uso da internet. Em 2008 foi implantado o projeto Iniciativa e-Escolinha que pretendeu "assegurar o acesso universal dos alunos do $1^{\circ}$ ciclo do ensino básico e dos respectivos professores a meios informáticos" (Resolução do Conselho de Ministros no 118/2009). 
Neste período, também, foi lançado o projeto do Portátil Magalhães para alunos de seis a onze anos. Em 2010 surgiu o projeto Aprender e Inovar com TIC que teve como objetivo utilizar as TIC para melhorar o aprendizado dos alunos por meio da rentabilização dos aparelhos para as escolas, privilegiando o $1^{\circ} \mathrm{Ciclo} \mathrm{do}$ Ensino Básico português.

Em face às realidades dos projetos não se pode negar o empenho português com as diferentes tentativas de integrar nas suas práticas pedagógicas o uso das tecnologias digitais. Elas possibilitam as novas formas com as quais pesquisamos, organizamos a informação e como passamos a nos comunicar, principalmente no que diz respeito a comunicaçáo entre professor e aluno. Hoje, muitos aplicativos da comunicação utilizados no âmbito social, foram inseridos no processo de aprendizagem, como o WhatsApp.

Especialmente ao tratar do uso desta tecnologia digital da comunicação no processo de aprendizagem, as práticas portuguesas apresentam algumas diferenças das práticas brasileiras e faz-se necessário conhecer os hábitos dos portugueses para chegar a algumas conclusóes. Os portugueses não utilizam com tanta frequência o WhatsApp como os brasileiros e algumas investigaçóes ajudam a justificar esta afirmação.

De acordo com a pesquisa da We Are Social e o Hootsuite a Digital in 2017: Western Europe, estudo que tem como objetivo apresentar resultado sobre o uso da internet, das mídias sociais e o uso dos dispositivos móveis em toda a Europa, o resultado divulgado em janeiro de 2017 afirma que do total de 10,28 milhóes de portugueses, 6,10 milhóes deles são utilizadores das redes sociais, onde 5,20 milhóes utilizam as redes móveis para acessar as redes sociais, sendo que esta rede social é o Facebook, confirmada por $69 \%$ e, consequentemente, informaram que utilizam o chat desta rede social com maior frequência (41\%), a frente do WhatsApp que obteve $27 \%$ das respostas. 
Outros dados que procuram confirmar o uso desta tecnologia digital da comunicação são apresentados na tese de doutoramento realizada na Universidade de Lisboa em 2016. Intitulada "Cyberbullying: a violência virtu@l conectada ao mundo real dos estudantes em contextos universitários do Brasil e Portugal” tem como objetivo "compreender como os estudantes do Brasil e de Portugal percepcionam o clima institucional e psicossocial nas suas universidades e como vivenciaram a problemática do cyberbullying".

Foram entrevistados 642 universitários brasileiros e 770 universitários portugueses. Em face aos resultados, a investigação obteve dados sobre o uso de tecnologias digitais utilizadas pela vitimização nos países. Em relação a Portugal, o resultado esteve sempre atrás do Brasil no que se refere ao uso do WhatsApp. A Tabela 3, a seguir, foi construída a partir dos dados da tese e apresenta números que são fundamentais para a justificativa do uso desta plataforma digital em Portugal.

Tabela 3 - Tecnologias utilizadas na vitimização em Portugal e no Brasil

\begin{tabular}{c|c|c}
\hline Tecnologias & Portugal & Brasil \\
\hline Facebook & $60,2 \%$ & $65,9 \%$ \\
\hline Messenger & $19,3 \%$ & $14,2 \%$ \\
\hline SMS/MMS & $23,6 \%$ & $8,1 \%$ \\
\hline WhatsApp & $1,6 \%$ & $24,8 \%$ \\
\hline
\end{tabular}

Fonte: Produção dos autores.

Os números da Tabela são interessantes e apresentam resultados que nos permitem refletir sobre as tecnologias utilizadas nos dois países. Quanto ao uso do Facebook e do Messenger, os dados se aproximam, mas no que se refere ao uso SMS/MMS há uma grande diferença. No Brasil houve um número pequeno de utilizadores e ao contrário aconteceu com o uso do WhatsApp, onde o número 
foi mínimo entre os portugueses e houve um maior número de aderência dos brasileiros.

$\mathrm{Na}$ Tabela 4, os números referentes ao SMS/MMS em Portugal também tiveram maior aderência em relação ao resultado do Brasil e, mais uma vez, o uso do WhatsApp obteve maior quantitativo do que em Portugal, diferença significativa.

Tabela 4 - Tecnologias utilizadas nas agressóes

\begin{tabular}{c|c|c}
\hline Tecnologias & Portugal & Brasil \\
\hline Facebook & $64,9 \%$ & $53,6 \%$ \\
\hline Messenger & $13,8 \%$ & $20,3 \%$ \\
\hline SMS/MMS & $17,0 \%$ & $5,8 \%$ \\
\hline WhatsApp & $6,4 \%$ & $41,3 \%$ \\
\hline
\end{tabular}

Fonte: Produção dos autores.

Apesar de ser uma investigação específica na área da Psicologia, os dados auxiliam para a discussão do uso das tecnologias digitais da comunicação nos dois países. $\mathrm{O}$ resultado também é interessante pelo fato de apresentar a frequência de uso do SMS/MMS.

Outro estudo realizado na Universidade de Aveiro (Portugal) por Santos (2012), intitulado "SMS: uma nova forma de comunicação, uma influência na Língua Portuguesa”, apresenta dados que comprovam a evoluçáo do SMS e importância que o SMS tem em Portugal sobrepondo as novas tecnologias digitais da comunicação.

Vinte anos após o início da implementação das SMS como forma de comunicação escrita, estas já não precisam de mostrar o seu valor nem de dar provas da sua utilidade. Hoje debatem-se com uma concorrência nova, diferente e recente, que são as redes sociais e os serviços de mensagens instantâneas agora existentes no telemóvel como o 
Viber $^{\oplus}$ e o Whatsapp (uma aplicação de SMS para Smartphones) que elevam a qualidade das SMS, possibilitando enviar mensagens de texto gratuitas para outros destinatários desde que os destinatários também tenham instalada a mesma aplicação, independentemente do tarifário em vigor. (SANTOS, 2012, p. 15).

$\mathrm{O}$ autor ainda afirma que o SMS tem muitas vantagens, além de ser mais confidencial esta forma de comunicação não necessita da utilização da rede de internet e o tarifário é muito mais em conta devido às promoçóes que são lançadas pelas operadoras de telecomunicaçôes móveis e devido aos tarifários pré-pagos.

Em contraponto, dados mais atuais vêm demonstrar que o uso de mensagens instantâneas por meio da internet está sendo uma prática adotada pelos portugueses e em expansão.

De acordo com o relatório estatístico dos serviços móveis referente ao $3^{\circ}$ trimestre de 2016, houve um decréscimo do envio de SMS para um acréscimo de mensagens por meio das tecnologias digitais pelo telefone celular, o que é compreensível devido a proporção em que as tecnologias digitais estão inseridas no cotidiano das pessoas.

Cerca quatro em cada cinco utilizadores do serviço de acesso à Internet através do telemóvel envia mensagens instantâneas (instant messaging). Esta redução é visível sobretudo nos escalóes entre os 15 e os 34 anos, que são aqueles onde se verifica uma utilizaçáo mais intensiva deste serviço. Os utilizadores de SMS nestes escalóes diminuíram cerca de 3 p.p. nos últimos dois anos, tendo simultaneamente aumentado a utilização de serviços de instant messaging em cerca de 40 pontos percentuais. (ANACOM, 2016, p. 19-20). 
O que não se pode afirmar especificamente é quais são as plataformas utilizadas nas mensagens instantâneas, mas os exemplos citados na investigação destacam o Facebook, Messenger e WhatsA$p p$. O que pode nos ajudar a pensar sobre qual plataforma é mais utilizada pelos portugueses e principalmente no que se refere ao uso educacional são os trabalhos acadêmicos, as dissertaçóes e as teses.

Para revisitar os trabalhos realizados em Portugal, procuramos mapear por meio do Repositório Científico de Acesso Aberto de Portugal (RCAAP), vinculado às universidades portuguesas, não houve resultado de dissertaçóes ou teses portuguesas sobre as experiências no uso do WhatsApp na educação. Ao realizar a pesquisa com o termo WhatsApp referente ao título, resumo ou palavra-chave os resultados obtidos apresentaram dissertaçôes e teses vinculadas a instituições brasileiras.

No Brasil, também as políticas de inserção de TDIC na educação remontam a década de 1980 com projetos que tinham como objetivo inserir as tecnologias digitais no ensino. $\mathrm{O}$ primeiro projeto chamava-se Projeto Educação com Computadores (EDUCOM) foi em 1983 e o projeto realizou a implantação de centros-pilotos em universidades públicas direcionados a pesquisa no uso de informática educacional para elaboração de softwares educativos, além da educação especial.

Seis anos depois surge o Programa Nacional de Informática Educativa (PRONINFE) que buscava apoiar o desenvolvimento e a utilização da informática nos ensinos do $1^{\circ}, 2^{\circ}$ e $3^{\circ}$ graus e educação especial, estimulava a criação de vários centros distribuídos pelo país, trazia a capacitaçáo contínua e permanente de professores para que fosse possível uma fundamentação pedagógica eficaz no uso das tecnologias. Outro projeto foi iniciado em 1992 e tinha a televisão como a tecnologia fundamental, foi o projeto Salto para o Futuro que tinha como ideal aperfeiçoar os professores da rede pública de ensino e dar formação continuada aos professores responsáveis pelo ensino fundamental e médio, todos da rede pública de ensino. 
Atualmente este projeto é um programa de TV passado nacionalmente que tem intuito de abordar diversas temáticas educacionais.

Em 1995, ainda com foco na televisão e também em VHS e DVD, é criado o projeto TV Escola que foi a primeira medida após o Decreto no 1.917/96 que criou as Secretarias Estaduais de Educação a Distância (SEED). Este projeto teve como objetivo capacitar professores do ensino fundamental e médio para o uso das ferramentas distribuídas pelo projeto com o intuito de contribuir com o aprendizado dos alunos. As ferramentas faziam parte do chamado Kit tecnológico uma antena parabólica, uma TV de 20 polegadas, um videocassete e 10 fitas VHS virgens, depois houve uma reformulação para DVD.

Também na busca de melhorar a qualidade do ensino foi criado o Programa Nacional de Informática (PROINFO), em 1997, que tinha como objetivo a formação inicial de 25 mil docentes na tentativa além da capacitação de técnicos de informática para a manutenção das ferramentas. O Programa Mídias na Educação foi lançado em 2005, era um programa de educação a distância, com estrutura modular, que visa proporcionar formação continuada para o uso pedagógico das diferentes tecnologias da informação e da comunicaçáo e tinha como principal público os professores da educação básica.

Em 2010, foi implementado nas escolas públicas um projeto semelhante ao projeto Portátil Magalhães em Portugal, Programa Um Computador por aluno (PROUCA). Foi entregue a cada aluno, por meio do Ministério da Educação, um laptop onde encontram-se programas educativos, games, fotos e comunicador instantâneo para auxiliar na aprendizagem, mais uma tentativa de inclusão digital na escola. Em atualização no ano de 2012 o projeto foi reformulado para uso de tablets, conhecido como Tablets na educação.

Quanto aos estudos sobre WhatsApp no Brasil, procuramos organizar os dados em dois momentos. No primeiro, Quadro 1, 
apresentamos um diagnóstico das linhas de pesquisa e sua localização territorial desses estudos, incluindo o ano de apresentação dos resultados. Num segundo momento, destacamos como o Whats $A$ $p p$ foi utilizado nas pesquisas, os objetivos, metodologias e resultados desses estudos.

Quadro 1 - Diagnóstico da distribuição territorial e institucional dos estudos

\begin{tabular}{|c|c|c|}
\hline Ano & Área & $\mathbf{U E}$ \\
\hline 2015 & LINGUAGENS E LETRAMENTOS & $\mathrm{PE}$ \\
\hline 2015 & LINGUAGENS E LETRAMENTOS & RGN \\
\hline 2015 & EDUCAÇÃO MATEMÁTICA & MGS \\
\hline 2015 & DIVERSIDADE E INCLUSÃO & RJ \\
\hline 2015 & ESTUDOS CULTURAIS & SP \\
\hline 2015 & EDUCAÇÃO BRASILEIRA & $\mathrm{CE}$ \\
\hline 2015 & EDUCAÇÃO E CONTEMPORANEIDADE & $\mathrm{BA}$ \\
\hline 2015 & ENSINO DE FÍSICA & RJ \\
\hline 2015 & LINGUAGENS E LETRAMENTOS & RGN \\
\hline 2015 & $\begin{array}{c}\text { DESENVOLVIMENTO SUSTENTÁVEL E } \\
\text { TRABALHO }\end{array}$ & RJ \\
\hline 2015 & CULTURA E SOCIEDADE & MA \\
\hline 2015 & LINGUAGENS E LETRAMENTOS & SC \\
\hline 2016 & ENSINO DE MATEMÁTICA & PR \\
\hline 2016 & ENSINO DE HISTÓRIA & TO \\
\hline 2016 & FILOSOFIA E ENSINO DE FILOSOFIA & RJ \\
\hline 2016 & $\begin{array}{c}\text { TEORIA E ANÁLISE DA ORGANIZAÇÃO } \\
\text { LINGUÍSTICA }\end{array}$ & PE \\
\hline 2016 & ENSINO DE ARTES & MG \\
\hline
\end{tabular}




\begin{tabular}{|c|c|c|}
\hline Ano & Área & UE \\
\hline 2016 & DISCURSOS MIDIÁTICOS E PRÁTICAS SOCIAIS & RJ \\
\hline 2016 & ENSINO DE CIÊNCIAS E MATEMÁTICA & MG \\
\hline 2016 & MATEMÁTICA & RJ \\
\hline 2016 & $\begin{array}{c}\text { EDUCAÇÃO BRASILEIRA: GESTÃO E PRÁTICAS } \\
\text { PEDAGÓGICAS }\end{array}$ & MG \\
\hline 2016 & ENSINO, CIÊNCIAS E NOVAS TECNOLOGIAS & PR \\
\hline 2016 & SAÚDE BUCAL & $\mathrm{DF}$ \\
\hline 2016 & LINGUÍSTICA & AL \\
\hline 2016 & ENSINO, CIÊNCIAS E NOVAS TECNOLOGIAS & PR \\
\hline 2016 & ARTES & MA \\
\hline 2016 & EDUCAÇÃO & SE \\
\hline 2016 & EDUCAÇÃO & $\mathrm{DF}$ \\
\hline 2016 & $\begin{array}{c}\text { GESTÃO DE SISTEMAS DE INFORMAÇÃO E DE } \\
\text { CONHECIMENTO }\end{array}$ & $\mathrm{BH}$ \\
\hline 2016 & EDUCAÇÃO E CONTEMPORANEIDADE & BA \\
\hline 2016 & LINGUAGENS E LETRAMENTOS & BA \\
\hline
\end{tabular}

Fonte: pesquisa dos autores.

Do total das 30 dissertaçóes pesquisadas, 12 foram defendidas em 2015 e 18 em 2016, destas, 4 são de mestrados profissionais, nas linhas de arte, matemática, gestão e somente uma se aproxima mais do campo da educação, na linha de ensino de ciências. Quanto às áreas, a proposta foi delimitar a Educação e a Comunicação e Informação como marcos centrais e áreas base e mapear o entorno, as aproximaçóes e roteiros por outras áreas. Neste sentido, merece destaque oito dissertaçóes em linhas que têm a Educação como fundamento (duas em Educação, duas em Educação Brasileira, duas em Educação e Contemporaneidade, além de uma em trabalho em discursos midiáticos e uma em estudos culturais). 
Na relação ensino e educação, podemos destacar nove dissertações (duas em Ensino, Ciências e Novas Tecnologias, duas em Ensino de Matemática e uma em Ensino de Ciências e Matemática, uma para o ensino de Física, Artes, História e Filosofia). Abrimos um parêntese para identificar o campo da Linguística, Letras e Artes com seis trabalhos, seguidos pela Matemática com quatro dissertaçóes.

Sobre a forma de utilização do WhatsApp nesses estudos, podemos destacar pelo menos duas. Uma direta e outra indireta. $\mathrm{Na}$ primeira, a ferramenta faz parte da própria pesquisa como estratégias e pedagogia fundamental, utilizada nas intervençóes ou pesquisa ação. Os pesquisadores utilizaram essa ferramenta para criar grupos que subsidiam as pesquisas, as práticas pedagógicas propostas, para compartilhar imagens e textos, tirar dúvidas, apresentar documentos para ampliar os conteúdos trabalhados em sala, sugerir leituras complementares e fortalecer o contato e a interação entre alunos e destes com os professores. Num outro grupo estáo os pesquisadores que usaram a ferramenta como instrumento de pesquisa, a partir dos grupos já criados foram usados como instrumento de pesquisas por meio do monitoramento das conversas e discussóes registrados nesses espaços.

A perspectiva de destaque do WhatsApp como objeto de pesquisa está clara quando analisamos os objetivos. Somente dois trabalhos, que corresponde a $6 \%$ do total pesquisado, trazem indiretamente essa ferramenta como objeto relacionado às TIC e as redes sociais. No restante dos outros, a ferramenta aparece nos específicos. Mais de $70 \%$ das pesquisas ocorreram na educação básica, com destaque para o ensino médio, no campo da linguagem, envolvendo o ensino de Português, Espanhol e Inglês. A educação a distância parece com experiências na Odontologia, na Filosofia, História e na formação continuada de professores. Outras áreas de formação superior foram contempladas com experiências no campo das Artes, da Matemática com cálculo diferencial e estágio não obrigatório. 
No tocante aos resultados das teses e dissertaçóes serve, para a maioria, as observaçóes de Lira (2015, p. 4) quando afirma que,

pedagogicamente, o uso da plataforma WA possibilita, em momentos extraclasse, o envio de comentários, questionamentos, avisos, a resolução de exercícios em grupos, enfim, a criação de uma espécie de intercâmbio progressivo de informação e conhecimento. Possibilita contatos interativos possibilita ainda o intercâmbio de leituras, trocas de interpretaçóes e o encaminhamento para leituras.

Para além dessa generalização, destaca-se também o uso da ferramenta como espaço de diálogo, para manter os estudantes envolvidos. Para os professores, nas experiências de intervenção, pesquisa ação e ou participantes, a plataforma contribui positivamente para a prática docente e amplia o espaço da sala de aula para além de seus muros. A cooperaçáo interativa aos ambientes virtuais e aprendizagem, as práticas de educação on-line e como instrumentos de pesquisa como espaço de registro de falas e texto, além de espaços de diálogo e discussão que podem ser usados como grupos focais.

Em seu estudo, Cavalcante (2016, p. 18) chama atenção para as características metalinguísticas da ferramenta. Para o autor ,o WhatsApp possibilita o "uso intenso de intersemioses áudio-escrita-imagens-emoticons, que configuram em um mosaico de semioses multimodais, que se (re)significam num mesmo espaço". No entanto, levanta também algumas questóes sobre o acesso a informaçóes referentes a pornografia, a exigência de uma dedicaçáo permanente por parte dos professores para responder e atender aos alunos.

\section{Conclusóes}

Podemos concluir que estamos diante de um paradoxo. Conhecemos as transformaçóes comunicacionais e sociais que a fer- 
ramenta WhatsApp vem provocando, desde seu lançamento aos dispositivos móveis e a telefonia digital, mas estamos diante de um novo objeto, notado, mas ainda não muito estudado por pesquisadores da educação. No entanto, já é perceptível o crescimento do interesse nesta ferramenta como centro ou periferia nas discussóes a respeito do impacto dos dispositivos móveis, das redes sociais digitais, dessa ferramenta multilinguística e multimidiática de comunicação, dos novos ambientes e plataformas de educação.

Em se tratando do WhatsApp mais especificamente, ainda náo nos parece ser uma preocupação de pesquisa para os portugueses. $\mathrm{O}$ número de trabalhos localizados para esta pesquisa ainda é muito pequeno. No entanto, em relação ao Brasil, conseguimos identificar 34 trabalhos no período de dois anos (2015/2016). Em várias áreas de conhecimento, com destaque para a educação e o campo da linguística. Teses (4) e dissertações, acadêmicas e profissionais esses trabalhos estão voltados para intervenção e pesquisa ação na prática docente e nos processos de aprendizagem com mediação das Tecnologias Digitais de Informação e Comunicação, com especial atenção para as redes sociais digitais - o WhatsApp e o Facebook.

Podemos concluir, considerando a pouca produção portuguesa, que a ferramenta e seu consumo no cotidiano social como meio de comunicação, acesso e troca de informação tem se ampliando e interferido no espaço escolar de forma positiva e negativa. Assim, como as pesquisas no Brasil chamam atenção para o fato da escola e dos docentes tentarem entender o fenômeno e sua influência na vida dos alunos e o impacto na aprendizagem. Se podem e como podem contribuir para melhorar a atenção, a interação, a colaboração, os interesses e a melhoria da aprendizagem com jovens e adolescentes. 


\section{Referências}

AGUADO, Juan Miguel; FEIJÓO, Claudio; MARTINÉZ, Inmaculada J. Introdución: de la cuarta pantallamal medio líquido. In: AGUADO, Juan Miguel; FEIJÓO, Claudio e MARTINÉZ, Inmaculada J. La comunicación móvil: hacia un nuevo ecosistema digital. Barcelona: Gedisa, 2013.

ANACOM. Serviços móveis: informação estatística $3^{\circ}$ trimestre de 2016. Disponível em: <https:/www.anacom.pt/streaming/ STM3T16.pdf? contentId=1400752\&field=ATTACHED_FILE $>$. Acesso em: 12 jun. 2017.

\section{ANALYSIS GROUP. Whatsapp economic impact} infographics. 2017. Disponível em: <http://www.analysisgroup. com/uploadedfiles/content/ news_and_events/news/ analysisgroup_whatsapp_economic_impact_report.pdf $>$. Acesso em: 10 jun. 2017.

CAVALCANTE, F.L. O trabalho com a oralidade: proposição, aplicação e análise de um debate regrado via whatsapp. 2016. Dissertação (Mestrado) - Universidade Católica de Pernambuco, Recife, 2016.

DEWEY, J. Democracia e educação. São Paulo: Companhia Editora Nacional, 1936.

KOOLE, M.L. A Model for Framing Mobile Learning. In: Mobile Learning: Transforming the Delivery of Education and Training, Edmonton. AU Press, 2009. Disponível em: <http://www.aupress.ca/books/120155/ebook/99Z_Mohamed_ Ally_2009-MobileLearning.pdf>. Acesso em: 10 jun. 2017. 


\section{LIRA, V.L. de S. Smartphone e ensino de língua portuguesa:}

lidando com conjuntos e sistemas de gêneros em atividades no whatsapp. 2015. Dissertação (Mestrado profissional em Letras) - Programa de Pós-Graduação em Letras - PROFLETRAS, Universidade de Pernambuco, Garanhuns, 2015.

OKADA, Alexandra. O que é cartografia cognitiva e por que mapear redes de conhecimento? In: Okada, Alexandra (Ed.). Cartografia Cognitiva: Mapas do conhecimento para pesquisa, aprendizagem e formação docente. Porto Cuiabá, Mato Grosso: KCM, 2008.

OXFORD DICTIONARIES. Blog Oxford Dictionaries. 2015. <http://blog.oxforddictionaries.com/2015/11/word-of-the-year2015-emoji/>. Acesso em: 10 jun. 2017.

SANTOS, A.M.A. de A. SMS: uma nova forma de comunicação, uma influência na Língua Portuguesa. 2012. Dissertação (Mestrado) - Universidade de Aveiro, Portugal, 2012.

SHARPLES, M.; TAYLOR, J.; VAVOULA, G. A Theory of Learning for the Mobile Age. In: The Sage Handbook of E-learning Research, London: Sage, 2007. p.221-247. Disponível em: < https://telearn.archives-ouvertes.fr/file/index/ docid/190276/filename/Sharples_et_al_Theory_of_Mobile_ Learning_preprint.pdf>. Acesso em: 10 jun. 2017.

SOUZA, S.B. de. Cyberbullying: a violência virtu@l conectada ao mundo real dos estudantes em contextos universitários do Brasil e Portugal. 2016. Tese (Doutorado) - Universidade de Psicologia, Universidade de Lisboa, Portugal, 2016.

TRAXLER, J. Current State of Mobile Learning. In: TRAXLER, J. Mobile learning: Transforming the Delivery of Education and 
Training, Edmonton. AU Press, 2009 p.9-24. Disponível em: <http://www.aupress.ca/books/120155/ebook/99Z_Mohamed_ Ally_2009-MobileLearning.pdf>. Acesso em 10 jun. 2017.

WE Are Social e o Hootsuite a Digital in 2017: Western Europe. Disponível em: <https://wearesocial.com/special-reports/digitalin-2017-global-overview>. Acesso em: 10 jun. 2017.

WHATSAPP. Blog do Whatsapp. 2017. Disponível em: <https:// blog.whatsapp.com/>. Acesso em: 10 jun. 2017. 


\title{
EXPANSÁO E RECONFIGURAÇÓES DAS PRÁTICAS DE LEITURA E ESCRITA POR MEIO DO WHATSAPP
}

\author{
Cristiane de Magalhães Porto - UNIT \\ Kaio Eduardo de Jesus Oliveira - UNIT \\ André Luiz Alves - UNIT
}

\section{Entrelaçamentos iniciais}

Ler significa aproximar-se de algo que acaba de ganhar existência. (CALVINO, 1999, p. 180).

Os resultados de 2015 do Programa Internacional de Avaliação de Alunos (PISA), que examina o desempenho escolar em mais de 60 países, entre eles o Brasil, suscitaram em debates e controvérsias em diferentes âmbitos. Os jornais The New York Times, o britânico Times Educational Supplement, o espanhol El País, por exemplo, discutiram de maneira crítica a situação do ensino médio de seus respectivos países à luz dos resultados do PISA.

No Brasil, a avaliação do Programa também foi tema de muito debate. $\mathrm{O}$ resultado mais preocupante, discutido pelos críticos, foi a estagnação do conhecimento dos adolescentes brasileiros em relação às avaliações anteriores. As médias dos alunos nas três áreas analisadas - matemática, ciências e leitura - praticamente estacionaram entre 2009 e 2015, deixando o Brasil nas últimas colocações da lista dos 69 países avaliados. 
Não entendendo claramente, o que lê, segundo o PISA, a maioria dos alunos brasileiros possui dificuldades para adquirir mais conhecimentos e, na concepção dos organizadores deste exame trienal, para exercer plenamente sua cidadania. Esses resultados refletem a realidade dos processos educativos do Brasil que se estabelece atualmente, caracterizando jovens e adultos escolarizados, mas sem conhecimentos básicos correspondentes ao seu grau de estudos, isto é, um conhecimento incapaz de auxiliá-los com suas próprias habilidades de leitura e a escrita para sua atividade social e profissional.

Não obstante, no cenário cultural estabelecido na Cibercultura, favorecido pela popularização do uso de Instant Messengers (Mensageiros Instantâneos), de redes sociais e dos dispositivos móveis em processos comunicativos; novos processos de leitura, escrita e de compreensão de textos têm se estabelecido como tarefa cotidiana. Tanto no Brasil, como em outros países, a generalização do uso de redes sociais e de aplicativos de mensagens instantâneas como o WhatsApp possibilita novas experiências nos processos de escrever e, principalmente, de ler. Cria assim um novo ambiente de autoria e produção de conteúdo permeado pela linguagem digital.

Por meio de aplicativos de mensagens instantâneas, como o WhatsApp, os processos comunicacionais e as práticas de leitura e escrita passam a ser constantes e constituídas por outras características e sentidos próprias da Cibercultura, organizadas pelo hipertexto, pela produção e compartilhamentos de áudios, vídeos e imagens. Essas características evidenciam uma nova prática de letramento, constituída por elementos e práticas que são próprios da cultura digital.

Podemos supor, assim, que as tecnologias de escrita, instrumentos das práticas de leitura e de escrita, desempenham um papel de organização e reorganização destes processos comunicativos e educativos. Lévy (1993) inclui as tecnologias de escrita entre as tecnologias intelectuais, responsáveis por gerar estilos de pensamento diferentes (observe-se o subtítulo de seu livro As tecnologias da inteligência: "o futuro do pensamento na era da informática”); esse 
autor insiste, porém, que as tecnologias intelectuais não determinam, mas condicionam processos cognitivos e discursivos.

Deste modo, o aplicativo WhatsApp, como mediador funcional de novas práticas de letramento social no processo comunicativo, possibilita reconfiguraçóes das habilidades de ler e escrever, que podem ser evidenciadas, entre outras questóes, a partir dos pontos básicos a seguir: $\mathrm{O}$ texto no papel é escrito e é lido linearmente, sequencialmente - da esquerda para a direita, de cima para baixo, uma página após a outra; já o texto no aplicativo - o hipertexto - é escrito e é lido de forma multilinear, de forma não sequencial, utilizando-se links ou rastros que vão trazendo telas numa reconfiguração de possibilidades, sem que haja uma ordem predefinida, ou uma relação direta com um único interlocutor.

A dimensáo do texto no papel é materialmente definida pelo autor: identifica-se claramente seu começo e seu fim, as páginas são numeradas, o que lhes atribui uma determinada posição numa ordem consecutiva. Enquanto o hipertexto produzido no WhatsApp tem a dimensão que o leitor lhe der: seu começo é onde o leitor escolhe, com um clique, a primeira tela, numa imagem, em um áudio ou vídeo; termina quando o leitor fecha o aplicativo ou ao finalizar o processo comunicativo com o interlocutor.

Mediante as questóes apresentadas até aqui, por meio de uma pesquisa bibliográfica, neste texto nos propomos discutir as reconfiguraçóes das habilidades e práticas de leitura e escrita no aplicativo WhatsApp. Assim, defendemos o argumento de que o app tem favorecido processos comunicativos por meio de mensagens instantâneas e possibilitado novas práticas de leitura e escrita. Este aspecto ressignifica estas habilidades, por meio de novos elementos próprios do aplicativo, do hipertexto e da cultura digital, como emojis, emoticons, áudios, vídeos e imagens.

Nas seçóes que seguem, buscaremos explorar a figura do leitor e escritor que na Cibercultura assumem as duas posiçóes, redimensionando os elementos da leitura e da escrita que caracte- 
rizam o processo comunicacional. Na seção seguinte, o WhatsApp, protagonista deste texto, será descrito, exploraremos suas potencialidades com o objetivo de informar como suas capacidades podem estabelecer novos formatos de leitura e escrita. Por fim, no último ponto, em meio à pesquisa bibliográfica, buscaremos enfatizar nosso argumento de que o WhatsApp favorece as novas e diversas práticas de leitura e escrita.

\section{O leitor escritor em tempos de Cibercultura}

Nosso mote para começar é "Penso que as palavras essenciais que me expressam se encontram nessas folhas que nem sabem quem sou” (BORGES, 2009). Assim, Jorge Luís Borges se expressa como homem de palavras que se perfaz entre criar e se expressar por meio destas. No entanto, elas não sabem quem ele é.

Pensarmos o leitor e o escritor na contemporaneidade passa um pouco pela mensagem contida no escrito do Borges, pois com o advento da Web 2.0 e com os dispositivos móveis em evidência, nos deparamos com uma nova relação entre emissor e receptor. $\mathrm{Ou}$ seja, percebemos que essas duas posiçóes se fundem e surge o "Interata”. Trata-se daquele que se assume como leitor e também autor, aquele que revela e busca desvelar as palavras, o ato de ler e escrever em um tempo contínuo. Não existe mais um receptor "passivo" e um emissor que prevalece. $\mathrm{Na}$ verdade, passou a existir uma interaçáo entre estes elementos e a mensagem, estes se entrelaçam e se projetam nesta nova forma de ler e escrever.

Sabemos que a interatividade permite a comunicação um-um e todos-todos, o conhecimento é construído interativamente entre o sujeito e o objeto a partir do momento que ele age e sofre uma ação do objeto, desenvolvendo assim a sua capacidade cognitiva. Isto é, o sujeito realiza a interação à medida que ele e o objeto se comunicam. Esta característica se aplica ao ato de ler e escrever. 
Os aplicativos conectados à internet tornaram-se um espaço plural, onde se produz e se publica textos que se sustentam não apenas nas palavras, mas nas imagens e, até mesmo, em sons. Santaella (2009) lança mão de um tipo de leitor que traz em sua prática fenômenos da Cibercultura. Trata-se do leitor ubíquo, aquele que lê e transita entre as formas, interaçóes de forças, movimentos, direçôes, traços e cores. Isto é, aquele que consegue imergir e submergir em meio às diversas direções proporçôes da nova maneira de ler e escrever na Cibercultura.

Por meio dos dispositivos móveis, à continuidade do tempo se soma a continuidade do espaço: a informaçáo é acessível de qualquer lugar. É para essa direçáo que aponta a evolução dos dispositivos móveis, atestada pelos celulares multifuncionais de última geração, a saber: tornar absolutamente ubíquos e pervasivos o acesso à informação, a comunicação e a aquisição de conhecimento. (SANTAELLA, 2013, p. 19).

Dessa forma, observamos que os artefatos que compóem este momento faz-nos deparar com a inovação das formas de ler e escrever. Não apenas a mudança de plataforma, mas o movimento de aprender em mobilidade, em múltiplos lugares e a qualquer instante. Um aplicativo como o WhatsApp é um dispositivo que propicia não apenas a mobilidade do usuário, mas o potencial transformador que este modelo híbrido de ler e escrever apresenta; nos desafiando a descobrir e articular novas formas de ler, escrever e aprender.

É importante salientarmos que, em tempo de conexão contínua, a escrita é fator essencial para a comunicaçáo na rede, mesmo estando integrada a imagens e sons. Tais aspectos configuram um hibridismo na maneira das pessoas se comunicarem e se relacionarem, tensionando relaçóes complexas entre o meio e o uso da linguagem.

As tecnologias contemporâneas, mais especificamente o aplicativo WhatsApp, reconfiguram as nossas relaçôes com os objetos e 
o uso que fazemos deles. O leitor-escritor do aplicativo é alguém que redimensiona o ato de ler e escrever, criando uma escrita mais participativa que se utiliza de imagens e sons para compor a mensagem.

Deparamo-nos, atualmente, com uma leitura e uma escrita como elementos principais da nossa vida social e cultural. A escrita contemporânea se reinventa por meio do uso de letras, símbolos, imagens e sons. Estes aspectos, em grande parte, marcam o modo de escrever, numa formulação de novas escritas, coadunando um acordo entre o contexto e a audiência.

Nesta cultura midiática o homem investiga e espera por conteúdos imersivos, a realidade aponta para uma transformação na maneira de consumir, usar e recriar a informação. Torna-se necessário fornecer instrumentos que, somados aos recursos disponíveis, permitam ao usuário uma experiência adequada à sua realidade tecnológica. Esses artefatos, a exemplo do WhatsApp, auxiliam na compreensão do mundo, por intermédio de experiências que estimulem seus sentidos, tornando-o partícipe no ato de enveredar pelo caminho da prática de ler, escrever e produzir novos textos e formatos.

É justamente neste mundo de polifonia e multiplicidade que se observamos um leitor com uma ação mais incisiva, ele abre máo da passividade que ainda poderia obstar a pluralidade desafiadora do texto e atua como um escritor em busca de um caminho onde o "reino das palavras" se configure, também, por meio de imagens e sons. A imagem das palavras fica como ato de comunicar e intercambiar ideias, pensando que as palavras estão aqui, mas elas ainda não nos explicam em essência.

\section{O WhatsApp e a ressignificaçáo dos processos comunicativos}

Na contemporaneidade, os processos comunicativos entre os sujeitos envolvidos no contexto educativo ganharam novos contornos. Estes podem ser mediados por dispositivos móveis e apli- 
cativos de mensagens instantâneas, como o WhatsApp Inc, no qual professores e alunos, ensinam e aprendem, simultaneamente - a partir de fluxos interacionais em espiral e colaborativos de construção de saberes.

Desse modo, o WhatsApp possibilita novas formas de interação, de autoria e de produção de conteúdo, assim como novas redes de transmissão de informaçóes; gerando transformaçóes nos processos comunicacionais, nos modos de ensinar e aprender, na prática de leitura e também de expressáo escrita.

Fundado em 2009 por Brian Acton e Jan Koum, na cidade estadunidense de Santa Clara, na Califórnia, a rapidez com que o WhatsApp se difundiu superou o crescimento do Facebook e fez com que Mark Zuckerberg, presidente e cofundador da rede social, comprasse, em fevereiro de 2014, o aplicativo por US\$ 19 bilhóes.

A popularidade do Instant Messenger já não é uma pauta nova para ninguém. $\mathrm{O}$ app de troca de mensagens está nas mãos de todo mundo há um bom tempo e não há dúvidas de que ele veio para ficar. Um estudo feito pela Opinion Box (2015), plataforma digital de pesquisa, indagou o seguinte: "Se você pudesse instalar um único Aplicativo no seu Smartphone, qual seria?”. O grande vitorioso foi o WhatsApp, escolhido por $56 \%$ das mulheres e $50 \%$ dos homens. Também foi o preferido pelos mais jovens: $45 \%$ dos respondentes com idades entre 16 e 29 anos o escolheriam, frente a 37\% das pessoas com 30 a 49 anos e $26 \%$ entre aqueles com 50 anos ou mais. Em segundo lugar ficou o Facebook.

WhatsApp é um trocadilho com What's $U p$ (E aí?). O site do desenvolvedor descreve-o como um $a p p^{1}$ (como é comumente chamado) multiplataforma que permite trocar mensagens instantâneas de texto (e multimídia) com o auxílio de dispositivos móveis

1 Um aplicativo ou aplicação móvel, conhecido normalmente por seu nome abreviado App, é desenvolvido para ser instalado em um dispositivo móvel (smartphone). Os apps têm o propósito de facilitar o dia a dia de seu utilizador, fornecendo-lhe as mais diversas funcionalidades com inúmeras possibilidades de uso. 
(smartphone, tablet, computador portátil etc.). Não há custo para enviar mensagens e ficar em contato com outros utilizadores que também possuam esta aplicação habilitada em seus dispositivos só é preciso estar conectado à internet (4G/3G/2G/EDGE ou WiFi quando disponível).

Além das mensagens básicas, os usuários deste mensageiro podem criar grupos, enviar mensagens ilimitadas com fotos, imagens, vídeos e áudios em tempo real - mediante uma interface moderna, agradável e fluida. Porque usar o WhatsApp como potencializador das práticas de leitura e escrita

$\mathrm{O}$ aplicativo do ícone verde funciona com um número telefônico e se integra perfeitamente com a agenda de contatos existente. Dessa forma, é possível criar Grupos que agregam contatos. Ao criar o Grupo, é permissível adicionar um avatar (foto da turma) na janela de conversas, nomeá-lo de maneira criativa (ambos editáveis pelos Administradores do Grupo: Professor e Líder de turma). Considera-se o perfil da classe, o componente curricular ou o conteúdo/atividade da vez e adiciona até 256 alunos-participantes. As interaçóes grupais acontecerão independente de o Professor salvar ou não todos os contatos dos alunos-participantes em sua agenda.

Figura 1 - Interaçáo grupal entre pares no WhatsApp

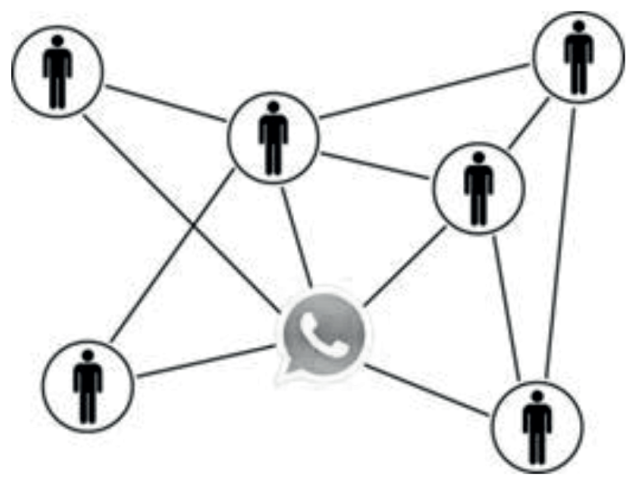

Fonte: Baixar WhatsApp (2017). 
Disponível em três versōes, o maior Messenger instantâneo do mundo pode ser acessado tanto no Smartphone (WhatsApp Messenger) como no Computador (WhatsApp Web ou WhatsApp Desktop). O WhatsApp Messenger é um aplicativo que pode ser "baixado" gratuitamente em Lojas de aplicativos como App Store e Google Play Store, por exemplo. Já as versões Web e Desktop para computadores permitem enviar e receber mensagens por meio do navegador de internet ou diretamente na máquina do utilizador, respectivamente. Por conseguinte, é o usuário quem decide como utilizar o app, uma vez que as três versóes funcionam exatamente do mesmo modo.

O WhatsApp permite desenhar, escrever e inserir emoticons/ emojis em fotos, imagens e vídeos, tornando os fluxos interacionais dinâmicos e descontraídos. Para isso, basta acessar a função da "Câmera" ou selecionar o arquivo nos álbuns/pastas do dispositivo móvel para edição, em seguida, anexá-lo a conversa.

Sem precisar anexá-lo a e-mails, o WhatsApp propicia enviar arquivos em PDF ou em ZIP, de até $100 \mathrm{MB}$, para os contatos, por meio da opção "Documento" no menu de compartilhamentos como também arquivos do Word, Excel e PowerPoint. No Grupo, basta o professor ou aluno-participante enviar arquivos em formatos diferenciados e, com um simples toque, fazer o download - facilitando o compartilhamento de anexos e enriquecendo a experiência de uso. Estes arquivos podem ser fotos, vídeos, documentos (nas extensôes citadas), localização, contato, entre outros.

É vantajoso, também, acessar o histórico de compartilhamentos de "Mídias" (imagem, áudio e vídeo), "Links" de sites diversos e "Documentos" enviados-recebidos nos fluxos interacionais por meio do menu "Dados do Grupo"; além do quantitativo de mensagens sinalizadas como favoritas. Em meio a tantas mensagens trocadas entre pares (professor-alunos, alunos-professor, alunos-alunos), estes conteúdos podem ser localizados com facilidade, enviados, automaticamente, para os álbuns/pastas do dispositivo 
móvel ou armazenados na rolagem de conversas. Portanto, basta clicar sobre o menu "Dados do Grupo" e selecionar qualquer uma das abas ("Mídia", "Documentos" ou "Links") para resgatar o conteúdo desejado.

Ainda em "Dados do Grupo", é possível silenciar o "assobio" inconfundível do "Zap Zap", personalizar o "toque de alerta", salvar as mídias recebidas no rolo da câmera, acessar a lista de participantes ("X de 256"), adicionar e convidar participantes para o Grupo via Link, limpar conversa e sair do Grupo. Já por intermédio da aba "Exportar Conversa”, o WhatsApp viabiliza o envio do histórico/ backup das mensagens de texto (em formato .txt) e multimídia dos fluxos interacionais por e-mail ou na nuvem - favorecendo o arquivamento de todas as informaçóes publicizadas no Grupo durante a conversação. Por outro lado, no rodapé deste menu, são registrados o iniciador, a data e o horário de criação do Grupo.

Recursos de texto riscado, negrito e itálico foram adicionados ao WhatsApp, permitindo que os pares personalizem o seu processo de escrita nos fluxos interacionais. Para enviar frases ou palavras riscadas, basta inserir o acento til $(-)$ no início e fim da frase ou palavra. Para ativar o negrito, usar o caractere asterisco $\left(^{*}\right)$ antes e depois da frase ou palavra. Caso queira aplicar o itálico na formatação, só acrescentar o underline (_) ao início e fim da frase ou palavra.

O Whats $A p p$ também admite alterar o estilo da letra utilizada na conversa. A fonte FixedSys remete à máquina de escrever, tem maior tamanho e espaço entre os caracteres e, por uma questão estética, poderá ser aproveitada para destacar alguma informação relevante do texto. Para usá-la, basta inserir três sinais de acento grave (' ') no começo e no final da frase. Vale ressaltar que, no transcorrer dos fluxos interacionais, é possível empregar vários tipos de formatação ao mesmo tempo; para isso, é só combinar os códigos.

Após liberar as formataçóes de texto, o app disponibilizou o recurso de citação, que possibilita responder a mensagens especí- 
ficas nas conversas em Grupo, inclusive, marcar o usuário a quem está se referindo. Assim, os pares poderão saber para qual mensagem (e interagente) a resposta foi direcionada. Para explorar esta funcionalidade, basta selecionar-pressionar a mensagem, clicar em "Responder" e depois enviar normalmente. Este recurso também é válido para as mídias compartilhadas durante os fluxos interacionais. Por outro lado, para citar alguém no Grupo, basta usar o símbolo arroba (@) antes de escrever o nome do utilizador e enviar a mensagem.

Outra função deste app é poder ter acesso aos detalhes de confirmação de envio (um tracinho cinza ou verde), entrega a visualização de uma determinada mensagem/arquivo mediante sinalização do indicador Double Check (checagem dupla) - ver quando e quantos alunos-participantes receberam (dois tracinhos cinzas ou verdes) e visualizaram (dois tracinhos azuis) o que foi compartilhado no Grupo - se habilitados nas configuraçóes de privacidade de cada usuário.

O campo status desta aplicação, junto à foto de perfil, é um indicador em tempo real do que se está fazendo ou pensando, mantendo os pares informados. Este, por sua vez, pode ser preenchido com frases pré-programadas do WhatsApp ("Disponível”, "Ocupado", "Em reuniáo" etc.) ou personalizado com frases de pensadores/ escritores, trechos de músicas e/ou emoticons/emojis, por exemplo. Agora chamado de "Recado", devido atualizaçáo mais recente, também é possível exibir no status; fotos, GIFs e vídeos que somem em 24 horas - semelhante à função "Stories" (Minhas Histórias) do Snapchat, Instagram e Facebook Messenger Day.

Outro recurso são marcadores que informam quando os interagentes estão "On-line", "Digitando" uma mensagem, "Gravando" um áudio e até a hora de seu último acesso: "Visto por Último"; se habilitado, individualmente, nas configuraçóes de privacidade. Outra característica do Instant Messenger é a pluralidade de emojis/emoticons - ícones ilustrativos usados nos fluxos intera- 
cionais que personalizam a comunicação e possibilitam incorporar elementos de humor, reações e sensações (modulaçóes no modo de enunciação).

Outra possibilidade interessante do "Uátzap" são as "Listas de Transmissóes" para enviar ou encaminhar, individualmente, mensagens de texto, vídeos, imagens e áudio para várias pessoas ao mesmo tempo.

A criptografia (em grego: kryptós, "escondido”, e gráphein, “escrita") ponta a ponta do WhatsApp é um fator importante de segurança que codifica as mensagens - sejam elas individuais ou em Grupos - para que somente o autor e o destinatário tenham acesso ao conteúdo e ao teor do que é trocado nos fluxos interacionais do aplicativo. Ou seja, durante a encriptação, o conteúdo das mensagens é transformado da sua forma original para outra ilegível; impedindo que ele seja interceptado por hackers, criminosos, incluindo o próprio WhatsApp.

O fenômeno que se tornou o WhatsApp Messenger já não surpreende ninguém. Segundo dados da pesquisa "Panorama Mobile Time/Opinion Box" (Abril/2016), o WhatsApp lidera o ranking dos Instant Messengers (Mensageiros Instantâneos) mais presentes na home screen dos brasileiros, lança novos recursos regularmente ${ }^{2} \mathrm{e}$ não há mais dúvida de que a concorrência tem um caminho bem longo para alcançá-lo.

Atentos à propagação deste aplicativo e de todas as mudanças sociais que ele tem provocado desde a sua criação - além de suas funcionalidades e possibilidades de uso elencadas acima - elegemos o WhatsApp como suporte e potencializador dos processos comunicacionais, dos modos de ensinar e aprender, das práticas de leitura e também de expressão escrita.

2 O WhatsApp é atualizado regularmente. Ao baixar a versão mais recente, é possível receber todos os recursos e melhorias disponíveis; como também, correções de bugs (erros). Logo, cabe ressaltar que estes pesquisadores exploraram algumas funcionalidades vigentes até a elaboração deste texto. 


\section{Observaçóes à guisa da conclusáo}

Neste texto, nos propomos a discutir as potencialidades e possibilidades do WhatsApp Messenger como mediador de outras práticas de letramento, escrita e leitura que se constroem no processo comunicativo e consequentemente educativo. Mediante estas inquietaçôes foi possível sustentar o argumento de que a comunicação e educação ubíqua possibilitada pelo WhatsApp oportunizam a elaboração de uma escrita permeada por novos elementos específicos da cultura digital.

Comumente, o texto no papel é escrito e lido de forma linear, sequencial, da esquerda para a direita, de cima para baixo, uma página após a outra; com a reconfiguração das habilidades de leitura e escrita no hipertexto e no suporte digital, outras possibilidades são erigidas. Assim, a comunicaçáo em aplicativos, a escrita e a leitura se configuram de forma multilinear, de maneira não sequencial. Utiliza-se de links ou rastros diversos que vão trazendo telas numa reconfiguração de possibilidades, sem que haja uma ordem predefinida ou uma sequência lógica dos acontecimentos. $\mathrm{Ou}$, ainda, uma relação direta com um único interlocutor.

Nesse contexto, o processo educativo por meio da escrita e leitura multilinear e não sequencial se articulam também mediante o descobrimento constante, em um modo de aprender permanente e ubíquo. Assim, o processo comunicativo mediado pelo WhatsApp é notável de serendipidade, ou seja, de buscas, pesquisas e de descobertas em uma reconfiguração da concepção de letramento que, agora, se reinventa com a inserção de sons, imagens e vídeos.

Em um simples clique, ou em vários cliques, pula-se livremente de uma página a outra, de um interlocutor para outro, viajando sem muita lógica, ou por uma lógica outra, desarticulada e rizomática, entre conteúdos discrepantes. Partimos, assim, de uma comunicação e escrita em um estilo próprio e tradicional, para um 
novo processo de leitura e de escrita com contextos e sentidos extremamente diferentes e inesperados.

Os Grupos do WhatsApp também são mais um recurso didático que podem ressignificar o processo de escrita e leitura. É uma prática que estamos desenvolvendo e aprendendo constantemente no uso cotidiano com a comunicaçáo com outros. Os usuários naturalmente se adequam aos critérios do processo de leitura e escrita grupal sejam com áudios, vídeos, imagens e textos.

As múltiplas formas de ler e escrever que nos proporciona o aplicativo WhatsApp são mais um motivo para repensarmos as nossas metodologias de ensino para leitura e a escrita na Cibercultura. Este aspecto faz surgir um novo estilo a leitura e a escrita se encontram nos fios dos mais diversos artefatos. Observamos a escrita, marcando seu espaço na internet, não apenas quantitativamente, mas, também, de maneira qualitativa. De acordo com Pinker (2016), os universitários estão escrevendo mais que gerações anteriores, não apenas utilizando símbolos, abreviaçóes e mensagens instantâneas, mas textos de boa qualidade.

Borges (1979), afirmou que "[...] o livro é outra coisa: o livro é extensão da memória e da imaginação". Podemos afirmar hoje que na Cibercultura nossa imaginação transborda as páginas dos livros e ganha forma em textos, imagens e sons. Tudo potencializado pela presença das tecnologias digitais e telemáticas no ciberespaço em um ecossistema que propicia a colaboração e o compartilhamento do ler e escrever entre letras, imagens e sons.

O Grupo do WhatsApp é mais um recurso didático. É uma prática que estamos desenvolvendo e aprendendo com ela. Nunca usamos a tecnologia desse jeito, então estamos achando ótimo. Os alunos estão aderindo aos pouco, mas todos que fazem parte dos grupos participam bem. Eles estão mais concentrados e conseguem entender melhor o que falamos nas aulas. A leitura facilitou muito a aprendizagem.

Por isso temos hoje significativas práticas de escrita e leitura via WhatsApp. Basta pensarmos nas práticas diárias de vários grupos 
criados no aplicativo onde são gerados comentários sobre aulas, livros lidos, situação política e econômica do País, entre outros. Este novo estilo de ler e produzir contorna os multidirecionamentos que usamos para ler os fenômenos da Cibercultura e como estes nos auxiliam em nosso cotidiano como leitor e produtor de textos e reflexóes.

\section{Referências}

BAIXAR WHATSAPP. Whatsappear. Disponível em: <http:// www.whatsappear.com.br/>. Acesso em: 13 jun. 2017.

BORGES, Jorge Luís. Oral. Buenos Aires: Emecé, 1979.

BORGES, Jorge Luís. Poesia. São Paulo: Companhia das Letras, 2009.

CALVINO, Ítalo. Se um viajante numa noite de inverno. São Paulo: Companhia das Letras, 1999.

COUTO, Edvaldo; PORTO, Cristiane; SANTOS, Edméa (Org.) App-Learning: experiências de pesquisa e formação. Salvador: Edufba, 2016.

PESQUISA Opinion Box. Disponível em: <http://zh.clicrbs.com. $\mathrm{br} / \mathrm{rs} /$ noticias/tecnologia/noticia/2015/05/whatsapp-e-o-apppreferido-dos-brasileiros-afirma-pesquisa-4765352.html>. Acesso em: 8 jun. 2017.

PESQUISA “Panorama Mobile Time/Opinion Box”. Disponível em: <https://revistapronews.wordpress.com/2016/06/28/ panorama-mobile-timeopinion-box-aponta-uso-de-apps-nobrasil-por-eles/>. Acesso em: 10 jun. 2017. 
PINKER, Steven. Guia de escrita: como conceber um texto com clareza, precisão e elegância. Trad. Rodolfo Ilari. São Paulo: Contexto, 2016.

PORTO, Cristiane et al. (Org.). Pesquisa e mobilidade na cibercultura: itinerâncias docentes. Salvador: EDUFBA, 2015.

SANTAELLA, Lucia. Comunicação ubíqua: repercussôes na cultura e na educação. São Paulo: Paulus, 2013. 


\title{
MOBILIDADE, WHATSAPP E APRENDIZAGEM: REALIDADE OU ILUSÁO?
}

\author{
Lúcia Amante - UAB-PT \\ Lígia Fontana - UAB-PT
}

\section{Introduçáo}

As tecnologias móveis fazem, indiscutivelmente e cada vez mais, parte do nosso quotidiano. São múltiplas as tarefas suportadas por estas tecnologias, elas transformaram-se em extensôes do nosso cérebro, dos nossos braços, dos nossos ouvidos, das nossas pernas, dos nossos olhos. Despertam-nos pela manhã, dão-nos as primeiras notícias do dia, consultamos o e-mail, com elas vamos ao banco, fazemos compras, vemos o último episódio da série preferi$\mathrm{da}$, acedemos às redes sociais, procuramos o restaurante onde queremos jantar, pesquisamos o caminho para lá chegar, escrevemos, falamos, jogamos, registamos imagens, tiramos notas, consultamos a agenda... enfim, muito, ainda muito mais, tudo por meio de um simples dispositivo que cabe na palma da nossa mão e que, na sua origem, servia apenas para efetuar ligaçóes telefónicas.

Se é indiscutível que estes dispositivos fazem parte da nossa vida e se, na generalidade dos nossos atos diários, existe sempre uma componente de aprendizagem, não será de estranhar que consideremos que as tecnologias móveis são também elas, com todas as suas potencialidades, meios e contextos de aprendizagem. São, de facto, ferramentas culturais do nosso tempo cujo uso importa 
analisar e aprofundar no sentido de compreender quais os desafios e oportunidades que colocam à educação.

Dirigimos, numa primeira fase, a nossa atenção para a aprendizagem móvel em geral, refletindo sobre o conceito, sobre algumas das suas características e sobre o seu potencial pedagógico. Discutimos depois a necessidade da formação inicial docente incorporar o uso transversal das tecnologias digitais nos seus currículos. Neste sentido, abordamos uma experiência de utilização do aplicativo WhatsApp em contexto académico, no âmbito do Projeto Mobile Learning: "Whatsapp na educação 3.0", desenvolvida por uma das autoras deste texto que atua como docente na formação de pedagogos, numa instituição de ensino superior no Brasil.

Procuramos, por fim, cruzando a reflexão teórica inicial com a experiência empírica analisada no âmbito da formação de professores, discutir os possíveis papéis, a relevância e as limitações da aprendizagem móvel em contextos de aprendizagem formal, bem como a importância da mediação pedagógica do professor nestes contextos.

\section{Virtualidades da aprendizagem móvel: o mundo na palma da máo}

A diversidade da pesquisa sobre aprendizagem móvel tornou difícil gerar uma única definição deste conceito, sendo que, como refere Traxler (2005) muitas destas definiçôes são centradas na tecnologia e não nas perspetivas dos aprendentes.

Cabe considerar a definição da Organização das Nações Unidas para a Educação, Ciência e Cultura (UNESCO, 2014, p. 7):

O mobile learning envolve o uso dos dispositivos móveis, isoladamente ou em combinação com outras tecnologias de informação e comunicação 
(TIC), de forma a permitir a aprendizagem a qualquer hora e em qualquer lugar. A aprendizagem pode se desdobrar em uma variedade formas: os utilizadores podem usar dispositivos móveis para aceder a recursos educacionais, ligarem-se com os outros utilizadores, ou criar conteúdo, em sala de aula, como fora das salas de aula. O mobile learning abrange também os esforços para suportar objectivos educacionais mais amplos, tais como, a administração eficaz dos sistemas escolares, melhorado a comunicação entre as escolas e as famílias.

As definiçôes de aprendizagem móvel enfatizam, como seria de esperar, a mobilidade (SHARPLES et al., 2009), a ubiquidade (SANTAELLA, 2013), também o acesso e o imediatismo (KUKULSKA-HULME et al., 2009), a conveniência (KYNASLA HTI, 2003) bem como o contexto de uso (KEARNEY; SCHUCK; BURDEN; AUBUSSON, 2012) cuja diversidade se associa particularmente ao uso dos dispositivos móveis.

$\mathrm{Na}$ verdade, a difusão alargada das tecnologias móveis e a sua ubiquidade permitem que os seus utilizadores as usem nas mais diversas situaçóes, em casa, no ónibus, na rua, no café, podendo dar lugar a um uso funcional (procurar uma rua, um endereço, encontrar um número de telefone etc.), a um uso de entretenimento (ver a novela, jogar um game, conversar nas redes sociais...), mas também a um uso educacional, transformando momentos "mortos" (nos transportes, nas filas de espera etc.) em tempos de aprendizagem que autores como Metcalf identificam como "stolen moments for learning" (METCALF, 2002), ou seja "momentos roubados para aprender".

Com efeito, os dispositivos móveis podem dar lugar a novas oportunidades e estratégias de aprendizagem, quer porque proporcionam um acesso imediato e omnipresente à informaçáo (KUKULSKA-HULME et al., 2009; SEPPALA; ALAMAKI, 2003), quer porque oferecem possibilidades de aprendizagem indi- 
vidualizada, informal, situada e colaborativa, não circunscritas aos contextos acadêmicos (CHEON et al., 2012, MARTIN; ERTZBERGER, 2013). Aumentam a motivação, em especial de alunos mais distantes e desinteressados (TRAXLER, 2010). Podem tornar-se em extensóes das salas de aula, permitindo prolongar o debate e a interação e subsidiar esse debate com contributos e registos proporcionados pela tecnologia recolhidos fora do contexto escolar, como veremos mais adiante na experiência de uso das tecnologias móveis que analisamos.

Seria, pois, importante as instituiçóes educativas e os professores reconhecerem esta realidade, procurando usar estes dispositivos como aliados da tarefa educativa, ou seja, como instrumentos promotores de cultura e de aprendizagem acadêmica. Contudo, como é sabido, apesar do conhecimento sobre o potencial do uso dos dispositivos móveis para potenciar a aprendizagem, é frequente serem interditos nas escolas. Ao fazê-lo, as instituiçóes passam a mensagem de que a tecnologia é algo "pouco sério", algo que se alia exclusivamente ao entretenimento e que se opóe à aprendizagem o que acaba condicionando a forma como as pessoas usam a tecnologia e como projetam a sua (in)utilidade com fins educacionais.

Moura (2016, p. 86) assinala que "os alunos chegam à escola com os seus dispositivos móveis, mas a maioria desconhece os benefícios da sua utilização em contexto educativo, porque simplesmente desconhecem que apresentam esta potencialidade”. No entanto, os dispositivos móveis não são meros artefactos de entretenimento, meros utensílios para realizar tarefas, meras ferramentas didáticas, são instrumentos culturais do nosso tempo. Como assinala Marco Silva (2012), devem ser considerados como interfaces que proporcionam novas formas de interação e, consequentemente, de relação entre todos, particularmente entre alunos e professores, os principais atores do processo educativo. Sendo usados como tal, podem ampliar o nosso reportório de conhecimento e a nossa afirmação como cidadãos. 
Como referido no relatório O futuro da aprendizagem móvel (UNESCO, 2014), é importante que os projetos com estas tecnologias se enquadrem na estrutura cultural e social das comunidades, onde estas tecnologias são já elementos efetivos. Tal como ampliam a interação quotidiana das pessoas, quer social, quer profissional, podem também ampliar a interação educativa, prolongando a sala de aula para lá do seu espaço físico (SANTAELLA, 2013a).

As tecnologias móveis permitem promover a conectividade contínua dos estudantes com ambientes de aprendizagem formal e os seus atores, sejam eles professores ou colegas, com quem partilham e debatem sobre temas acadêmicos, construindo conhecimento nessa interação e aprofundando dinâmicas de trabalho colaborativo que podem favorecer os processos de aprendizagem. Simultaneamente promovem iniciativas personalizadas, centradas no aluno, levando-o a assumir um papel ativo na construção do conhecimento como é desejável que suceda.

\section{Aprendizagem móvel e mediaçáo pedagógica}

A aprendizagem ubíqua, que inevitavelmente se liga à aprendizagem móvel, confundindo-se com ela, é eminentemente informal (SANTAELLA, 2013). Se é óbvio que as tecnologias móveis são excelentes promotoras das aprendizagens informais, das tais aprendizagens espontâneas, não planeadas, que ocorrem nos mais variados contextos, importa equacionar o seu papel quando o que está em jogo é outro tipo de aprendizagens.

Sem explorarmos aqui as diferentes abordagens dos principais teóricos da aprendizagem, como Skinner, Piaget, Vigotsky, Ausubel ou Bruner, podemos no entanto salientar que existem diversos tipos de aprendizagem e, entre eles, uma grande categoria que poderemos designar, de modo simplificado, de aprendizagem formal ou aprendizagem acadêmica. Esta apresenta, por norma, 
um caráter sistemático e intencional, assente na organização de atividades planeadas que se constituem como estímulos, tendo em vista atingir determinadas metas, definidas pela instituição escolar. De referir ainda que muitas destas aprendizagens envolvem uma natureza específica, que implica reflexão, análise, resolução de problemas, entre outras competências.

Como já assinalamos atrás, as tecnologias móveis são excelentes para aumentar a interação entre o aluno e o meio que o cerca, favorecendo a colaboraçáo, a troca, a partilha. Mas estes processos de aprendizagem abertos, ativados pelos dispositivos móveis, são, como assinala Santaella (2013, p. 291) "processos espontâneos, assistemáticos e mesmo caóticos, atualizados ao sabor das circunstâncias e de curiosidades contingentes". Nesse sentido, como alerta Laurillard (2007) é necessário estar atento ao quão problemático ou improdutivo pode ser a aprendizagem informal ou a aprendizagem sem supervisão, resultante do acesso livre e contínuo à informação (SANTAELLA, 2013).

Como sabemos, a tecnologia, por si só, não será um fator determinante na capacidade de realização de aprendizagem. As intervençóes efetivas com base na aprendizagem móvel requerem uma compreensão holística da relação entre a tecnologia e fatores sociais e culturais (UNESCO, 2014), surge como fundamental a mediação pedagógica do professor, na condução do processo.

Por mediação pedagógica entendemos a atitude, o comportamento do professor que se coloca como um facilitador, incentivador ou motivador da aprendizagem, que se apresenta com a disposição de ser uma ponte entre o aprendiz e sua aprendizagem - não uma ponte estática, mas uma ponte "rolante", que ativamente colabora para que o aluno chegue aos seus objetivos (MASETTO, 2008).

Sem essa mediação intencional e previamente planeada, que caracteriza a educação formal, as potencialidades da aprendizagem móvel podem ficar reduzidas a muito pouco: 
O universo das redes é um espaço em constante mutação, dispersivo e assistemático. $\mathrm{O}$ que ele tem de positivo, a oferta desmedida de informação que pode fortalecer a aprendizagem é contrabalançado, no outro extremo, pela ausência de orientação cujos efeitos negativos atingem particularmente aprendizes ainda imaturos. (SANTAELLA, 2013, p. 305).

Kearney e Maher (2013), a propósito do uso das tecnologias móveis na formação de professores, enfatizam a importância de colocar a pedagogia no centro da aprendizagem móvel, em vez da tecnologia. Esta preocupação deve ser central para que as atividades que recorram às tecnologias móveis não surjam apenas como mais uma moda, mas assumam um significado pedagógico efetivo, significado esse que os dispositivos móveis e o seu uso poderão potenciar.

Precisamos da tecnologia para ajudar na construção da autonomia dos estudantes, para dar acesso a todo um universo de informaçóes, mas precisamos também de novas docências que façam desse acesso parte do projeto pedagógico e não apenas de tecnologia sem a devida mediação pedagógica (CASTELLS, 2003). Precisamos da tecnologia, mas não podemos esperar tudo da tecnologia. A tecnologia não dispensa, só por si, a necessidade de concentração, o foco na realização de uma atividade específica, o esforço de raciocínio que algumas aprendizagens requerem, o espaço de pensamento e de reflexão que tantas vezes se exige ao longo de um processo de construção de conhecimento.

Há que considerar, por outro lado, que existem aprendizagens formais de natureza muito distinta, e se, todas elas, podem beneficiar das oportunidades que a tecnologia disponibiliza, nem todas elas podem ocorrer, com base exclusiva, no que a tecnologia proporciona. Simultaneamente, existem também diferentes estilos cognitivos (SANTAELLA, 2004, 2013) que influenciam o modo 
como se aprende e o próprio conteúdo afeta o desempenho no que se refere à aprendizagem (RIDING; RAYNER, 1998). Todas estas especificidades interferem com os cenários de aprendizagem móvel e os condicionam.

\section{Projeto Mobile Learning: WhatsApp na Educação 3.0 e formação de professores}

\section{$\mathrm{O}$ aplicativo Whats $A p p$}

O aplicativo WhatsApp constitui-se como uma ferramenta digital especialmente concebida para os dispositivos móveis, que permite o envio de mensagens instantâneas (texto, áudio, vídeo, ficheiros diversos) e de chamadas grátis, por meio de ligação à Internet.

Este aplicativo configura-se também, em grande medida, como uma rede social, com características particulares. Na verdade, o aplicativo permite a partilha e a conectividade entre grupos de utilizadores específicos, restritos, que se encontrem conectados entre si por meio da rede dos seus dispositivos móveis. "As redes consistem não apenas em pessoas e grupos sociais, mas também em artefatos, dispositivos e entidades" (SANTAELLA; LEMOS, 2010, p. 40), pelo que podemos considerar que se concretizam na inter-relação entre sistemas de objetos e pessoas. Como refere Recuero (2009, p. 69) "uma rede social é sempre um conjunto de atores e suas relaçôes".

Em fevereiro de 2016, o aplicativo alcançou a marca de um bilhão de usuários. De acordo com o Mobile Ecosystem Forum (MEF), o Brasil é o segundo país do mundo com maior uso de WhatsApp, logo atrás da África do Sul, constituindo-se como o comunicador instantâneo mais popular no País.

A utilização do WhatsApp tem revelado de acordo com vários estudos (HERNÁNDEZ, 2016) um elevado potencial para criar espaços de trabalho alternativos aos espaços tradicionais designada- 
mente, criando ambientes informais de aprendizagem que suscitam a colaboração entre os seus participantes. Os resultados apontam para a valorização, por parte dos estudantes, de aplicativos que tornam a comunicação mais fluida e informal, especialmente em horários extra letivos.

\section{Uma palavra sobre formação de professores na era digital}

É natural que à grande difusão do aplicativo Whats $A p p$ se associem diversas experiências de uso das tecnologias em contextos educativos diversos, tendo por base esta ferramenta, designadamente ao nível da formação de professores, como a que abordaremos mais à frente neste texto.

Antes disso, porém, uma palavra sobre a necessidade de repensar a formação dos professores, adequando as estratégias de formação destes profissionais ao contexto da sociedade digital, aos seus saberes, necessidades e características do seu público alvo. Não deixa de ser paradoxal que a profissáo de professor, cujo foco de atuação são as novas geraçóes e sua preparação para o futuro, se mantenha tão amarrada ao modelo de escola herdado do séc. XIX. $\mathrm{Na}$ verdade "a maioria dos modelos educacionais, submetidos à lei da inércia, que é marca registrada da maioria das instituiçóes de ensino, ainda permanece inamovível e presa exclusivamente à lógica da era de Gutenberg" (SANTAELLA, 2013, p. 296).

Como podem as instituiçóes que formam professores contrariar este paradoxo?

Como assinala Nóvoa (2009, p. 31), “Os novos modos de profissionalidade docente implicam um reforço das dimensóes colectivas e colaborativas, de trabalho em equipa, da intervenção conjunta nos projetos educativos de escola”.

Refere o autor que as práticas que tenham como referência uma dimensão coletiva levam à emancipação profissional, consolidam a profissão e a autonomia dos seus saberes e dos seus valores. 
Ora, na sociedade tecnológica em que vivemos, essa dimensão coletiva é cada vez mais requerida e simultaneamente facilitada pelo uso das tecnologias digitais. Estas têm evidenciado um grande potencial para o desenvolvimento de trabalho colaborativo, designadamente em contextos on-line (PALLOFF; PRATT, 2010), propiciando o acesso a múltiplos recursos, ao mesmo tempo que facilitam a construção e a partilha de saberes.

Simultaneamente, se pretendemos que os futuros docentes usem os diversos recursos tecnológicos na sua futura prática pedagógica, tendo em vista potenciá-la, importa proporcionar-lhes uma formação que integre o uso desses dispositivos, essenciais para a nova forma de pensar e produzir conhecimento. Mais do que acrescentar disciplinas tecnológicas ao currículo, importa que as próprias instituiçóes e os seus docentes recorram ao uso pedagógico das tecnologias digitais integrando-as, de modo transversal, no trabalho letivo desenvolvido nos cursos de formação inicial docente. Poderemos desse modo potenciar a sua apropriação pelos futuros pedagogos tendo em vista práticas educativas diferenciadas, inovadoras e de qualidade.

Baran (2014) numa pertinente revisão da literatura relativa à integração da aprendizagem móvel na formação de professores conclui que é necessário estabelecer modelos pedagógicos e teóricos que possam orientar os responsáveis na conceção de experiências de aprendizagem móvel tendo em vista fornecer aos futuros docentes estratégias de integração da aprendizagem móvel nas salas de aula. Refere ainda, com base em vários autores, que:

A pesquisa sugeriu que as tecnologias móveis precisam ser utilizadas como ferramentas de aprendizagem que servem para aprimorar a experiência metodológica dos professores, não ser incorporada apenas como uma tecnologia propriamente dita (Husbye \& Elsener, 2013). A aprendizagem móvel deve ser significativamente 
integrada e aplicada pelos professores de todos os cursos, náo apenas nos cursos de tecnologia (Foulger 139 et al., 2013). Uma visão limitada a respeito da integraçáo dos dispositivos móveis nos ambientes de aprendizagem são definitivamente uma barreira (Herro et al.,2013). (BARAN, 2014 , p. 25 , tradução nossa $)^{1}$

Partilhamos esta perspetiva e defendemos que a metodologia de formação assume a maior importância como facilitadora da transferência das práticas que se entendem como desejáveis no dia a dia de trabalho do professor. A estratégia de formação baseada no isomorfismo pedagógico (NIZA, 1997, p. 25) definida como "metodologia que consiste em experienciar, através de todo o processo de formação, as atitudes, métodos, capacidades e modos de organização que se pretende que venham a ser desempenhados nas práticas profissionais" permitirá, acreditamos, a apropriação do potencial educacional e pedagógico dos recursos digitais, designadamente dos dispositivos móveis.

\section{Projeto “Mobile Learning: Whatsapp na Educação 3.0”}

No sentido atrás enunciado, houve uma experiência de aprendizagem móvel desenvolvida por uma das autoras do texto que atua como docente no contexto da formação inicial docente, no âmbito do Projeto "Mobile Learning: Whatsapp na educação 3.0" (FONTANA, 2016). Partimos do pressuposto de que se os futuros pedagogos explorarem o uso e potencialidades pedagógicas dos dispositivos móveis na sua própria formação, mais facilmente

1 Research has suggested that mobile technologies need to be used as tools for enhancing preservice teachers' experiences, not as an add-on incorporating technology for its own sake (Husbye \& Elsener, 2013). Mobile learning must be meaningfully integrated into all teacher education courses, not only technology courses (Foulger 139 et al., 2013). Limited, unclear best practices regarding preparing teachers for the integration of mobile devices is a definite barrier (Herro et al.,2013). (BARAN, 2014, p. 25) 
farão a transposição do seu uso para os contextos de ensino-aprendizagem com os seus estudantes.

Procurou-se dar resposta à questão: $\mathrm{O}$ uso de aplicativos móveis pode colaborar para uma aprendizagem significativa dentro da formação inicial do professor? Adotou-se uma metodologia qualitativa, tendo por base a observação participante como principal instrumento de recolha de dados.

O "Projeto Mobile Learning: WhatsApp na educação 3.0" propóe-se concretizar o uso de ferramentas de comunicação, designadamente do aplicativo WhatsApp. A implantação deste projeto teve início em 2014, tendo dado lugar a diversas experiências no âmbito de disciplinas da formação inicial de docentes, e envolveu cerca de 90 participantes. Dessas experiências, selecionamos uma delas, para breve abordagem neste texto: "Grupo de estudo online: A arte no seu percurso" atividade inscrita em diferentes disciplinas e que decorreu totalmente online.

Esta atividade pretendeu discutir conceitos fundamentais para o trabalho pedagógico referente ao diálogo da arte como aspeto de transformação social e cultural do indivíduo. A proposta de realização da atividade usando o WhatsApp teve como estímulo desencadeador a possibilidade de, por meio desta ferramenta, levar os estudantes a registarem e partilharem experiências pessoais de contacto com a arte, nomeadamente apelando à sua observação e registo no percurso quotidiano entre casa e faculdade.

Foi criado um grupo específico no WhatsApp, definido um design que desse identidade ao momento de formação, bem como um cronograma de início e fim das tarefas e um roteiro de orientação para o seu desenvolvimento. Damos exemplo de algumas imagens criadas para dar início a diferentes etapas de trabalho em ambiente mobile.

Num primeiro momento, foram disponibilizados recursos de trabalho, dando lugar, num segundo momento, a um debate com pesquisa on-line e de campo sobre a história da arte e suas intera- 
ções, em que contamos com a colaboração de uma especialista na área $^{2}$. O material foi essencialmente oferecido em imagem, designadamente vídeos e URL's dos museus para visita on-line.

Num terceiro momento, teve lugar a exposição virtual das obras de arte registadas pelos estudantes, ao longo do seu percurso casa-faculdade, bem como a interação com o grupo e com a docente, a propósito das mesmas e da sua relação com o tema em estudo. Por fim, um quarto momento deu lugar à visita virtual a uma exposição num dado museu, sendo os estudantes interpelados a deixar diversos contributos e convidados a um debate final. Em todas as etapas, a participação poderia ocorrer em qualquer momento, no transporte, em casa, no trabalho, dando assim autonomia ao estudante na escolha do tempo e do espaço de trabalho.

A atividade registrou uma adesão muito positiva. Observouse que os alunos participavam em qualquer horário. Debateram sobre a história da arte, trouxeram exemplos diversos e o momento de partilha das fotos do seu percurso casa-faculdade registrou particular envolvimento.

A docente foi sempre procurando levá-los a alicerçar as interaçóes geradas nos referenciais teóricos debatidos pelo grupo, realizando intervençôes estratégicas no sentido de orientar e aprofundar a discussão, ou seja, adotando comportamentos de scaffolding ${ }^{3}$ (BRUNER, 1978). A atividade foi avaliada, com base em critérios definidos previamente e partilhados pela docente, como qualidade do conteúdo exposto, interação com os participantes, sugestóes de assuntos, suscitar novos debates, produzir conteúdo, entre outros.

2 Colaboração da Prof. ${ }^{a}$ Lilian Lizardo, especialista em educação arte e história da cultura.

3 Este conceito refere-se aos passos dados por um adulto (professor) no sentido de delimitar uma dada tarefa procurando levar o aprendente a centrar-se nas competências em jogo num dado processo de aquisição. Trata-se de antecipar o desenvolvimento da compreensão da tarefa por parte do sujeito e de agir em consonância com essa antecipaçáo através de "intervençóes estratégicas" (BRUNER, 1978). 


\section{Consideraçóes finais}

Se é certo que com a mobilidade o ciberespaço digital se fundiu de modo indissolúvel com o espaço físico e se essa hipermobilidade (SANTAELLA, 2013a) traz toda uma nova configuraçáo das formas de educar e de aprender, também é certo que às possibilidades tecnológicas e às oportunidades de aprendizagem que os dispositivos móveis oferecem, por vezes, algum deslumbramento, algum modismo ou alguma superficialidade de análise. Importa, pois, não deixar que esse deslumbramento ofusque uma análise realista do seu papel na educação. Quer isto dizer que pretendemos nesta discussão não perder o foco que é precisamente a aprendizagem, designadamente a aprendizagem formal, já que é sobre esses contextos que se discute no presente texto a relevância de uso do mobile learning.

Como balanço final da experiência de utilização do WhatsA$p p$ fica a ideia de que podemos dar uma resposta afirmativa à questão inicial colocada: "O uso de aplicativos móveis pode colaborar para uma aprendizagem significativa dentro da formaçáo inicial do professor?". Sim, a atividade foi pertinente e permitiu dar maior significado à aprendizagem, estabelecendo ligação com a realidade de cada estudante, expandindo a colaboração, a partilha e o debate para lá da sala de aula.

Podemos dizer que o envolvimento dos estudantes, em geral, foi uma realidade permitindo-nos antecipar que esta experiência proporcionou aprendizagem e assumiu verdadeiro significado para os participantes. A este envolvimento não terá sido alheio o trazer da realidade quotidiana do estudante para a discussão teórica. Essa partilha enriqueceu o debate e conferiu uma maior autenticidade às tarefas propostas, favorecendo ainda a proximidade entre estudantes e entre estudantes e professores.

Todavia, evidenciaram-se limitaçóes. Sendo o aplicativo um meio de comunicação instantânea, em algumas situaçôes ficou di- 
fícil para a docente acompanhar de modo síncrono toda a discussão, dado que a qualquer hora os estudantes podiam participar. Por outro lado, o sistema acumula as mensagens sem organização por tópicos de assunto, ao contrário do que é viável no fórum de um qualquer ambiente virtual de aprendizagem. $\mathrm{O}$ tópico criado pelo docente para o debate era, pois, o único organizador, náo existindo subtópicos que estruturassem a discussão. Por outro lado, tornouse evidente que o uso do aplicativo deveria ser restrito a grupos de pequena dimensáo.

Outro ponto crítico, apontado pela docente, remete para a ausência de preparação para a atividade por parte dos alunos. $\mathrm{Ou}$ seja, alguns participaram, mas sem terem feito as leituras prévias indicadas, o que levou a intervençóes superficiais e de opiniâo, sem a profundidade requerida para o debate e compreensão do assunto. É certo que esta limitação não é específica de uma situação de mobile learning, mas não quisemos deixar de a enunciar, já que podemos colocar como hipótese que o acesso à informação por meio de dispositivos móveis favoreça uma abordagem mais superficial dos materiais disponibilizados, quer pelas características físicas e técnicas do dispositivo (ecrã de pequenas dimensóes, entre outras), quer pelo contexto da sua utilização que pode ser pouco propício a concentração e leitura.

Se, por um lado, como refere Pelissoli (apud SANTAELLA, 2013, p. 299) a principal vantagem do mobile learning se prende com o facto de o aluno deixar de ver a aprendizagem como algo que "tem hora e local para acontecer", por outro lado, questionamonos se essa possibilidade contínua de poder aprender em qualquer tempo e em qualquer lugar não coloca em risco a profundidade $\mathrm{e}$ a atenção dedicada à tarefa de aprender. A este propósito valerá a pena atender aos diferentes tipos de perfil cognitivo dos utilizadores das redes, especialmente das redes móveis, que têm vindo a emergir nestes contextos, designadamente os "três diferentes tipos de leitores” de que nos fala Lúcia Santaella (2004; 2013). 
Sobressaem assim desta experiência e da reflexão teórica feita algumas indicaçóes a considerar. A necessidade de um design instrucional, que compreenda todo o planeamento do processo de ensino-aprendizagem surge-nos como essencial. Este planeamento inclui atividades, estratégias, modos de avaliação, métodos e recursos disponibilizados. Estamos convictas de que, sem esse trabalho prévio, o sucesso da atividade fica comprometido. Também a mediação pedagógica se revelou essencial, no sentido de dar um rumo e balizar a abordagem dos temas em questão, suscitando desafios e dando-lhe suporte.

Julgamos, pois, que estas atividades podem ser vistas como complementares de outras, beneficiando os contributos particulares que advêm da sua natureza móvel; contudo não serão, só por si, suficientes para atingir os objetivos propostos, em situações de aprendizagem formal. Ou seja, não dispensam um trabalho do aluno que vai além dos momentos de interação e partilha que o aplicativo proporciona, ainda que estes sejam da maior relevância. Mas esta experiência teve uma dupla função. Para lá dos conteúdos trabalhados estava em jogo a aprendizagem do processo pelos participantes, ou seja, o uso do aplicativo e dos dispositivos móveis como instrumentos de trabalho num contexto de aprendizagem formal.

Se os estudantes vivenciaram este processo de forma positiva, como entendemos ter sucedido, estarão mais próximos de no futuro transferirem esta aprendizagem de uso das tecnologias digitais para os seus contextos de trabalho enquanto docentes. E esse é um ganho que assume enorme relevância. As redes, os dispositivos tecnológicos e toda a cultura digital trouxeram novos modos de criar, construir e distribuir conhecimento, na ecologia cognitiva das redes os atos de aprendizagem mudaram substancialmente, alterando também substancialmente o papel de professores e de alunos, que não se encaixam mais nas categorias tradicionais (SANTAELLA, 2013).

Diríamos que tomando como analogia a teoria da epistemologia genética de Jean Piaget, desfeito o equilíbrio durante tantas 
décadas assentamos a nossa visão convencional de aprender e ensinar há que assimilar novos objetos e esquemas, há que procurar novos equilíbrios, incorporando nesse processo a atual ecologia das mídias digitais, nas palavras de Santaella (2013). O desafio está aí, não o podemos ignorar.

\section{Referências}

BARAN, E.A Review of Research on Mobile Learning in Teacher Education. Educational Technology \& Society, v.17, n.4, p.17-32, 2014.

BRUNER, J. The role of dialogue in language acquisition. In: SINCLAIR, A.; JARVELLA, R.; LEVELT, W.J.M. (Ed.). The child's conception of language. New York: Springer, 1978. p.241-256.

CASTELLS, M. A galáxia da internet: reflexôes sobre a Internet, os negócios e a sociedade. Rio de Janeiro: Jorge Zahar, 2013.

CHEON, J. et al. An investigation of mobile learning readiness in higher education based on the theory of planned behavior. Computers \& Education, v. 59, n. 3, p. 1054-1064, 2012.

FONTANA, L.A.M. Whatsapp na educação: criar, construir, compartilhar. In: BUSARELLO, R.I.; BIEGING, P.; ULBRICHT, V.R. (Org.. Sobre educaçáo e tecnologia: processos e aprendizagem. São Paulo: Pimenta Cutural, 2016. p. 255-270. Disponível em: <http:/www.pimentacultural.com/\#!sobreeducacao-e-tecnologia-volume-2/ctqy>. Acesso em: jun. 2016.

HERNÁNDEZ, F.A.L.; PÉREZ, M.M.S. Factores que inciden en la aceptación de los dispositivos móviles para el aprendizaje en educación superior. Estudios sobre Educación, n. 30, p. 175-195, 2016. 
KEARNEY, M. et al. Viewing mobile learning from a pedagogical perspective.In Research in Learning Technology, v. 20, n. 1, p. 1-17, 2012.

KEARNEY, M.; MAHER, D. Mobile learning in math teacher education: Using iPads to support pre-service teachers' professional development. Australian Educational Computing, v. 27, n. 3, p. 76-84, 2013.

KUKULSKA-HULME, A. et al. Innovation in mobile learning: A European perspective. International Journal of Mobile and Blended Learning, v. 1, n. 1, p. 13-35, 2009.

KYNASLAHTI, H. In search of elements of mobility in the context of education. In: KYNÄSLAHTI , H.; SEPPÄLÄ, P. (Ed.). Mobile learning, Helsinki: IT Press, 2003. p. 41-48.

LAURILLARD, D. Pedagogical forms for mobile learning: Framing research questions. In: PACHLER, N. (Ed.). Mobile learning: Towards a research agenda. London: WLECentre, the Institute of Education, University of London, 2007. p.153-175.

MARTIN, F.; ERTZBERGER, J. Here and now mobile learning: An experimental study on the use of mobile technology. Computers \& Education, v. 68, n. 1, p. 76-85, 2013.

MASETTO, M. T. Mediação pedagógica e o uso da tecnologia. In: MORAN,J.M.; MASETTO M.T.; BEHRENS, M.A. Novas tecnologias e mediação pedagógica. São Paulo: Papirus, 2008. p.141-171.

METCALF, D.S. Stolen moments for learning.Learning developers'Journal. [On-line] 2002. Disponível em: <https:// 
www.learningsolutionsmag.com/articles/410/stolen-moments-forlearning-an-overview-of-wireless-e-learning-development>. Acesso em: jun. 2017.

\section{MOBILE ECOSYSTEM FORUM (MEF). Report}

2017. Disponível em: <https://mobileecosystemforum. $\mathrm{com} /$ programmes/consumer-trust/global-consumer-trustsurvey-2017/>. Acesso em: jun. 2017.

MOURA, A. Aprendizagem Móvel e ferramentas digitais para inovar em sala de aula. In: SOUZA, K. P. R. et al. (Org.). Jornadas Virtuais: Vivências e Práticas das Tecnologias Educativas.

SEDUC; Fortaleza: Instituto Brasileiro de Informação em Ciência e Tecnologia, IBICT, 2016. 250p. Disponível em: <https:// jornadasvirtuais.files.wordpress.com/2016/12/versc3a3o-jornadasvirtuais-final.pdf>. Acesso em: jun. 2017.

NIZA, S. Formaçáo cooperada - ensaio de auto-avaliaçáo dos efeitos da formaçáo no projecto amadora. Lisboa: Educa e Movimento da Escola Moderna Portuguesa, 1997.

NÓVOA, A. Professores. Imagens do futuro Presente. Lisboa: Educa, 2009.

PALLOFF, R.M.; PRATT, K. Collaborating online: Learning together in community. V. 2. San Francisco: Jossey-Bass, 2010.

RECUERO, R. Redes sociais na internet. Porto Alegre: Sulina, 2009. (Coleção Cibercultura). 
RIDING, R.J.; RAYNER, S. Cognitive styles and learning strategies: understanding style differences in learning and behaviour. London: David Fulton Publisher, 1998.

SANTAELLA, L. Navegar no ciberespaço: o perfil cognitivo do leitor imersivo. São Paulo: Paulus, 2004. p.191.

SANTAELLA, L. Desafios da Ubiquidade para a educação. In: Ensino Superior, UNICAMP - as novas mídias e o ensino superior. 2013a. Disponível em: <https://www. revistaensinosuperior.gr.unicamp.br/artigos/desafios-daubiquidade-para-a-educacao >. Acesso em: jun. 2017.

SANTAELLA, L. A ecologia pluralista da comunicaçáo: conectividade, mobilidade, ubiquidade. São Paulo: Paulus, 2013. SANTAELLA, L.; LEMOS, R. Redes sociais digitais: a cognição conectiva do Twitter. Sáo Paulo: Paulus, 2010. p.137.

SEPPALA, P.P.; ALAMAKI, H.H. Mobile learning. Teacher training. Journal of Computer Assisted Learning, v. 19, n.3, p.330-335, 2003.

SHARPLES, M. et al. Mobile learning: Small devices, big issues. In: LUDVIGSEN, S. et al (Ed.). Technology-enhanced learning: Principles and products. Berlin: Springer-Verlag, 2009. p. 233-249. Disponível em: <http://www.ifets.info/ journals/17_4/2.pdf>. Acesso em: jun. 2017.

SILVA, M. Sala de aula interativa. São Paulo: Loyola, 2012.

TRAXLER, J. Mobile learning- it's here but what is it? In Interactions Journal University of Warwick: Warwick 9,1, 2005. Disponível em: <https://www2.warwick.ac.uk/services/ldc/ 
resource/interactions/issues/issue25/>. Acesso em: jun. 2017.

TRAXLER, J. Students and mobile devices. Research in Learning Technology, v.18, n.2, 2010.

UNESCO. O Futuro da aprendizagem móvel: implicações para planejadores e gestores de políticas. Brasília: UNESCO, 2014. p.64. Disponível em: <http://unesdoc.unesco.org/ images/0022/002280/228074POR.pdf>. Acesso em: jun. 2017. 


\title{
WHATSAPP COM FUNÇÁO STORIES: ENSINAR E APRENDER NA MAGIA DO INSTANTE
}

\author{
Edvaldo Souza Couto - UFBA \\ Joana Dourado França de Souza - UFBA
}

\section{Introdução}

Em todo lugar, hoje, é natural encontrar pessoas trocando, freneticamente, mensagens de texto, áudios, fotos e vídeos por meio de dispositivos tecnológicos. Para muitos desses indivíduos é inconcebível não verificar, logo ao acordar, a avalanche de notificaçóes e novidades que surgem a todo o momento nas telas dos smartphones e tablets. Desejar "bom dia" para familiares, se informar sobre o cenário político local, nacional e internacional, alertar colegas de trabalho sobre um possível atraso, assistir vídeos divertidos e motivacionais, atualizar os amigos sobre os acontecimentos da vida cotidiana, dentre outras interaçóes, são absolutamente comuns e acontecem desde o despertar até o horário de dormir de parte expressiva das pessoas que vivem o mundo contemporâneo.

Estima-se que no Brasil, até o final de 2017, se terá uma quantidade de smartphones equivalente à de habitantes, em torno de 208 milhóes de aparelhos (CAPELAS, 2017). Esse dado expóe o uso massivo desses dispositivos tecnológicos. Provavelmente nem todos os brasileiros irăo possuir tal dispositivo no prazo citado. Esta informação demonstra que há um expressivo acesso e uso desta tecnologia. $\mathrm{E}$ a forte presença desses aparelhos inteligentes na vida das 
pessoas se dá, essencialmente, porque eles permitem conexões ubíquas, em qualquer lugar e a qualquer momento. As conexões são condiçôes indispensáveis para os usuários, ávidos em trocar mensagens, compartilharem conteúdos, narrarem suas próprias vidas ininterruptamente, de maneira multimídia, na internet.

A grande maioria destas conexóes contínuas acontece em aplicativos (apps) de redes sociais digitais e de troca de mensagens instantâneas. O Facebook e o WhatsApp, utilizados preferencialmente ou apenas por meio de smartphones e tablets, contabilizaram números hiperbólicos em quantidade de usuários e interaçóes em 2016. Estes programas, respectivamente, alcançaram a marca de 1,8 bilhão (KURTZ, 2016) e 1 bilhão (PRADO, 2015) de usuários e são, notoriamente, os mais populares em todo o mundo. Todavia, apesar do grande sucesso exposto por meio das funcionalidades já existentes, tais aplicativos precisam apresentar, constantemente, novidades para se manterem e ampliarem seus públicos. A função Stories, postagens que em, no máximo, 24 horas deixam de existir nas memórias dos apps, tornou-se a principal atualidade neste contexto e, por isso, foi incorporada a estes e outros softwares.

As Stories são atrativas porque acompanham a velocidade vertiginosa e a liquidez contemporânea, atendem ao agora perene do presente cenário da cibercultura. Pois, no contexto atual de conexóes ubíquas e pervasivas, denominado de era da mobilidade, o fluxo intenso de troca de informações e novidades, em permanente movimento, torna descartável o que já aconteceu.

Rastrear o passado das interaçóes perde a relevância em um contexto o mais importante é estar presente, literalmente fluir junto com o movimento temporal presente do fluxo contínuo de interação. Então, uma funcionalidade que elimina o obsoleto passado está em plena consonância com a contemporaneidade. Para o WhatsApp, especialmente, o acréscimo da função stories, enquanto status de seus usuários, serve para, além das interações contínuas 
por mensagens, publicizar para todos os contatos, no prazo de um dia, o que está sendo feito "aqui e agora".

Crianças e adolescentes acompanham, naturalmente, este intenso fluxo de novidades das redes e dos aplicativos. Usufruem de todas as funcionalidades disponibilizadas e as dominam com facilidade. Os dispositivos tecnológicos conectados são suas próteses personalizadas, que compóem e transformam de maneira significativa suas vidas. Desta forma, as subjetividades, os modos de ser destes sujeitos hiperconectados são hedonistas, exibicionistas, consumistas e, ao mesmo tempo, são também participativos, comunicativos e colaborativos.

Esta juventude, completamente imersa neste universo hiperconectado, também está presente, praticamente todos os dias, em instituições educacionais. Contextos bastante distintos dos que se tem, hoje, via internet. Desta forma, professores precisam conhecer, se apropriar e participar desta atual configuração da cibercultura para poder interagir com os jovens estudantes. E, para além da apropriação e participação, é necessário pensar também possibilidades pedagógicas atreladas a reflexôes sobre os usos e significados de funcionalidades de aplicativos, especialmente, as Stories do WhatsApp.

Este estudo problematiza a adoção e recorrência da função Stories em várias redes sociais, a dissolução de características específicas e o risco de padronizar ambientes antes marcados por experiências ricas que ressaltavam a diversidade de mecanismos. A partir de estudos sobre a cibercultura e das redes sociais digitais no âmbito da educação, o texto apresenta resultados de uma pesquisa qualitativa com um grupo de professores que relata possibilidades pedagógicas do WhatsApp com função Stories. São discutidos os significados do ensinar a aprender, lembrar e esquecer, registrar e apagar conteúdos na magia do instante em nossas comunicaçôes ubíquas.

O método utilizado foi o da pesquisa qualitativa, de cunho descritiva e analítica. Esse método foi escolhido porque se preocupa em investigar a realidade que não é quantificável, que "trabalha 
com o universo de significados, dos motivos, das aspiraçóes, das crenças, dos valores e das atitudes" (MINAYO; GOMES, 2009, p. 21). Entrevistamos quatro professores, que estão na faixa etária de 30 a 40 anos, por meio dos aplicativos Instagram e WhatsApp, durante os dias 7 a 11 de junho de 2017. O critério de seleção dos entrevistados foi que publicassem, constantemente, Stories e fossem professores.

O texto foi estruturado em três seçóes. A primeira descreve o aplicativo de mídia social WhatsApp e a função Stories, destacando suas potencialidades para o tema em questão. A segunda analisa a memória, a efemeridade e a espetacularização da vida cotidiana na era da mobilidade a partir de uma perspectiva pedagógica. E a terceira seção associa a fundamentação teórica ao campo empírico a partir das análises das entrevistas dos professores selecionados para este trabalho.

\section{WhatsApp: disponibilidade permanente}

Por três vezes, o aplicativo WhatsApp foi bloqueado pela justiça, no Brasil, duas vezes em 2015 e uma em 2016 (WHATSAPP..., 2016). Em todos esses momentos houve uma intensa repercussão com notícias em tons apocalípticos como se a comunicação entre as pessoas tivesse sido suspensa por meio destes bloqueios. A comunicação, obviamente, não foi suspensa, todavia este era o sentimento coletivo. Estas situaçóes expõem, então, a grande importância deste aplicativo no cotidiano das pessoas.

O Whats $A p p$ é um aplicativo multiplataforma, gratuito, para troca de mensagens instantâneas e multimídias entre pessoas. $\mathrm{O}$ programa também permite a criação de grupos para comunicação coletiva via textos, emojis, imagens, áudios e vídeos, além da possibilidade de efetuar chamadas de voz, semelhantes a ligaçóes telefônicas. Os usuários são registrados por meio dos números de seus respectivos telefones celulares e as listas de contatos são construídas 
a partir do acréscimo de números de aparelhos, smartphones ou tablets, que também possuem o app. Certamente, a conexão entre os contatos telefônicos por um programa com interfaces de fácil manuseio e com recursos muito superiores aos de troca de mensagens via SMS determina o expressivo sucesso deste aplicativo.

Criado em 2009, o WhatsApp, em quatro anos, alcançou a marca de 450 milhóes (GOMES, 2014) de usuários, número que corresponde a um rápido crescimento quando comparado ao da principal rede social digital, Facebook, que cresceu um terço deste valor em um mesmo período de tempo. Este crescimento exponencial do aplicativo chamou a atenção de Mark Zuckerberg, dono do Facebook, que, em fevereiro 2014, comprou o WhatsApp por 16 bilhóes de dólares. Atualmente, com 1 bilhão de usuários que trocam 42 bilhóes de mensagens por dia, ele é o aplicativo responsável por significativa parte das interaçóes das pessoas e, por isso, as tornam permanentemente conectadas e disponíveis nele.

Esta disponibilidade contínua associada às diversas funcionalidades do aplicativo já corresponde a um ambiente propício para trocas, para interaçóes entre estudantes e professores em grupos e comunicaçóes afins. É comum encontrar grupos de turmas escolares que utilizam o WhatsA $p p$ como ambiente de suporte para práticas pedagógicas ou até como ambiente virtual para processos de ensino-aprendizagem. Como, por exemplo, a promoção de diálogos filosóficos entre professores e alunos, de acordo com a experiência de utilização do WhatsApp como estratégia metodológica para o ensino de Filosofia no ensino médio, no Instituto Federal do Maranhão (ARAÚJO; JÚNIOR, 2015).

Todavia, a nova funcionalidade, adicionada em fevereiro de 2017, a função Stories, devido ao pouco tempo de existência, constitui-se como um campo aberto para novas possibilidades pedagógicas neste programa e também fomenta reflexóes sobre os tipos de interações que acontecem em rede. 


\section{Função Stories: qual é o status agora?}

A função Stories surgiu no aplicativo de rede social Snapchat. Neste $a p p$, as publicaçóes de fotos e vídeos duram 24 horas na linha do tempo e as mensagens privadas são excluídas em, no máximo, 10 segundos após visualização. Com estas funcionalidades, o Snapchat alcançou rapidamente o número de 200 milhóes de usuários ativos por dia e, por isso, em 2013, Mark Zuckerberg, tentou, sem sucesso, comprar o programa por 3 bilhões de dólares. Devido a esta recusa, a partir de 2016, o dono do Facebook incluiu em todos os seus aplicativos a função Stories (recursos totalmente semelhante aos que se tem no Snapchat), inclusive no WhatsApp, como o status dos seus usuários.

Antes o status do WhatsApp era uma frase, com textos e/ou emojis, de até 139 caracteres, que permanecia, por tempo indeterminado, no perfil do usuário. Com a chegada das Stories, em um primeiro momento, o status, com o formato anterior, foi eliminado para dar espaço à nova funcionalidade. Os usuários, imediatamente, reivindicaram o retorno da função anterior e viram com "maus olhos" o acréscimo das Stories no WhatsApp, que também já estava presente no Instagram e no Facebook ('CADÊ..., 2017).

As Stories não foram retiradas, todavia o "velho" status retornou ao app em outro lugar e com outro nome, "recado". O estranhamento inicial, no entanto, não inibiu o rápido crescimento do uso da nova função que, atualmente, já possui 175 milhóes de usuários diários ativos, valor superior ao do Snapchat que perdeu, nos últimos meses, de maneira abrupta, parte expressiva de seus participantes (FUNÇÃO..., 2017).

$\mathrm{Na}$ função Stories do WhatsApp, assim como nos outros aplicativos que ela faz parte, as publicaçóes de fotos, gifs e vídeos (que também contam com a opção de customização com emojis, filtros e textos) duram até 24 horas na memória do programa. Na interface principal do aplicativo esta funcionalidade tem destaque, pois 
divide espaço com os comandos para as conversas, de mensagens instantâneas, e as chamadas telefônicas. As postagens, além de serem publicadas como status provisórios dos usuários, visíveis para todos os contatos, podem ser enviadas para contatos específicos e, como no Snapchat, são eliminadas logo após serem visualizadas.

As imagens podem ser registradas no próprio programa, por meio de uma interface de câmera semelhante a que se tem nos dispositivos tecnológicos. E os contatos podem interagir, a partir dos status, ao clicar no botáo e responder para enviar mensagens privadas, por meio de textos ou áudios, para quem fez a postagem. Em suma, a dinâmica das Stories consiste em permitir a publicação do "status" atual dos usuários, no devir dos acontecimentos do dia, para consumo, interação e descarte entre os respectivos contatos.

A memória efêmera deste recurso provoca uma interação distinta em relação à comunicação via mensagens instantâneas e chamadas de voz. As histórias cotidianas contadas na função Stories, com duração de um dia, motivam publicaçóes mais cotidianas, sem muitas ediçôes e prescriçôes. Características que podem proporcionar novidades para as práticas pedagógicas de professores conectados com as transformaçóes da cultura digital.

\section{Memórias efêmeras: contar histórias na era da mobilidade}

Registrar e compartilhar os momentos da vida não corresponde a açôes novas. Os mais significativos acontecimentos, desde tempos remotos, são registrados em textos, fotos e vídeos para, sucessivamente, serem compartilhados e apreciados por familiares e amigos, em especial. Como essas ocasióes, casamentos, formaturas e nascimentos de filhos, por exemplo, não são frequentes, tais registros são facilmente contabilizados e, na maioria das vezes, muito bem arquivados para a posteridade. Todavia, em tempos de efeme- 
ridades e espetacularização da vida cotidiana, as memórias apresentam diferentes duraçóes, formatos e significados.

Chartier e Chartier (2016) evidenciam que, na história da humanidade, as tensões entre memória e esquecimento são recorrentes. Dois temores, neste contexto, são frequentes: o medo da multiplicação incessante de escritos, de livros, de ideias inúteis e o medo da perda, da falta, do esquecimento. Os autores discutem, desta forma, a necessidade de apagamento como condição essencial da memória, pois, segundo eles, o esquecimento é importante para não paralisar o pensamento com recordaçóes constantes.

Nesse viés, eles descrevem o personagem Funes, el memorioso, do livro Ficciones, de Borges (1997). Funes um homem jovem atormentado por sua memória perfeita não se esquece de nada e, por não esquecer, lembra-se, a todo o momento, de cada minúcia da vida. Por isso, não consegue pensar, pois o pensamento exige generalizaçóes, isto é, exige o esquecimento. E, também, não consegue dormir porque não se liberta do peso das memórias do mundo. Funes morre derrotado pela sua memória.

$\mathrm{Na}$ era da mobilidade as conexóes, por meio dos dispositivos móveis, acontecem em qualquer lugar e a qualquer momento. $\mathrm{O}$ indivíduo com um Smartphone conectado via wifi, 3G ou 4G percorre espaços geográficos e virtuais durante o devir da vida cotidiana, transita entre estes dois ambientes, interage com eles. Em todos esses processos vão "interligando máquinas, pessoas e objetos urbanos” (SANTAELLA; LEMOS, 2010, p. 123). Por isso, os registros e sucessivos compartilhamentos no meio digital dos acontecimentos cotidianos, ordinários, tornaram-se habituais e incessantes.

Há desta forma um fluxo ininterrupto de informaçóes, de conteúdos, que, devido a intensidade, tornam-se descartáveis, esquecíveis na mesma velocidade que surgem nas telas. Certamente seria ainda mais insuportável para o personagem Funes, de Borges (1997), viver no mundo contemporâneo e seu excesso de possíveis memórias. 
Parte significativa do fluxo de informaçóes que circulam nas redes é de narrativas espetacularizadas da vida cotidiana. Narrativas pessoais, privadas que dizem respeito a subjetividades alterdirigidas, orientadas para olhares alheios (SIBILIA, 2015). Desta forma, as banalidades do dia a dia tornam-se espetáculos nas telas, são pavoneadas para apreciação do outro, para as audiências que cada um administra em seus ambientes de rede.

O que de fato importa, então, é transformar as vidas ordinárias em realidades ficcionalizadas com recursos midiáticos, em meio ao fascínio das nossas subjetividades sideralizadas e mais ou menos inventadas (COUTO, 2014). Ou seja, os registros, que antes se restringiam aos grandes acontecimentos, passam a ser ininterruptos na era da mobilidade e podem corresponder a qualquer circunstância vivida, desde que seja espetacularizada. A função Stories, neste cenário, é um palco para estes espetáculos.

A ordem cronológica das publicaçóes da função Stories, que são apresentadas das mais antigas para as mais novas, serve para contar histórias do início ao fim num prazo de um dia. Memórias efêmeras que no dia seguinte já foram esquecidas para, assim, abrir espaço para novas narrativas. Rebouças e Menezes (2016) dizem que esta dinâmica é uma espécie de "crematório", pois descarta totalmente o que já é feito para ser efêmero. Por que a fluidez das redes sugere o esquecimento como uma necessidade para a permanência das trocas intensas e vertiginosas. $\mathrm{O}$ espetáculo da vida cotidiana por meio das tecnologias móveis precisa de um palco de novidades para acontecer e este recurso, portanto, atende de maneira plena a esta demanda.

A memória, neste contexto, é feita de esquecimentos para o pleno fluxo de conteúdos. As produçôes, as participações e os compartilhamentos dos usuários neste recurso têm essa premissa como uma das principais motivaçóes. Para a conjuntura educacional, especialmente, esta funcionalidade pode se constituir como espaço favorável para potencializar processos de ensino-aprendizagem. $\mathrm{O}$ 
personagem de Borges (1997), devido a sua memória prodigiosa, era incapaz de alcançar qualquer forma de abstraçáo, de pensamento, já que "aprender sem parar, ou se lembrar de tudo, não é pensar, pois pensar é esquecer diferenças, generalizar, abstrair. No mundo sobrecarregado de Funes, só havia detalhes, quase imediatos" (CHARTIER; CHARTIER, 2016, p. 77).

Desta forma, o uso de um recurso como a função Stories pode promover práticas pedagógicas que fomentem o que carecia em Funes, o pensamento, a criatividade. A educação escolar feita, essencialmente e historicamente, de lembranças sólidas e rígidas, semelhantes às deste personagem, pode, também, seguir o fluxo dos esquecimentos que constituem as redes, a contemporaneidade, em suas práticas, para transformar, assim, a memória e as aprendizagens.

\section{WhatsApp com função Stories: ensinar e aprender na magia do instante}

A função Stories é um recurso que exalta a velocidade vertiginosa da internet, a efemeridade da duração das trocas de informaçóes que acontecem nela e a espontaneidade de postagens que ocorrem no fluxo dos acontecimentos cotidianos. As outras funcionalidades dos aplicativos de redes sociais mantêm os registros das publicaçóes, o que de certa forma é significativo, porque a memória, também das redes, é feita de lembranças e esquecimentos.

Contudo, a ausência de rastros corresponde ao motor que dá velocidade às trocas desta funcionalidade. Pois, muito provavelmente, o pleno esquecimento que pauta este cenário reduz significativamente receios, inibiçóes e pudores que existem em outros espaços das mídias e redes sociais digitais. Nesta fluidez, adolescentes, jovens, estudantes publicam e interagem ininterruptamente. Mas não só eles. Os professores estudados neste texto, além de assíduos usuários, pensam sobre as possibilidades pedagógicas da função Stories. 
Ter e administrar perfis em redes e mídias sociais digitais (RIBEIRO; FALCÃO; SILVA, 2012) é condição praticamente indispensável para viver a cibercultura. E o que, inicialmente, servia apenas para manter contatos, conversar com amigos, compartilhar significativos acontecimentos da vida, atualmente, possui diferentes características e funçôes, como exteriorizar a vida privada para uma audiência, de pessoas conhecidas ou não, fazer contatos de trabalho, promover e vender inúmeros produtos, dentre outras possibilidades.

Os usuários, então, vivem e usufruem destes múltiplos usos das redes e, por isso, buscam experimentar, cada vez mais, sites e aplicativos que apresentem novidades e funcionalidades pouco exploradas capazes de promover mais e mais sensaçóes e saberes, como as Stories. Com os professores entrevistados, para este estudo, presentes neste universo, não é diferente. Todos os quatro entrevistados, nomeados aqui de A, B, C e D, afirmam que usam regularmente a função Stories e que as suas publicaçôes, neste recurso, sáo mais comuns, isto é, apresentam e representam o dia a dia:

Uso o Stories. As publicações são mais simples. Às vezes até imagens que não estão tão legais estão lá, porque são coisas do dia a dia. Rotinas simples que podem ser publicadas por este recurso. (B)

Eu gosto muito desse recurso apesar de inicialmente ter sentido que era 'demais'e ter visto muitos dos meus amigos reclamando também. Do ponto de vista de usuário, eu acho que melhora a comunicação e a interação entre as pessoas, é como se você tivesse participando do dia a dia de vários amigos e fazendo-os participar do seu. (A)

Eu utilizo a função Stories de publicaçôes, gosto, procuro apresentar um conteúdo diferente das publicaçôes por tempo indeterminado das redes sociais. Geralmente eu posto coisas mais cotidianas, coisas mais 'bobas', posto o que eu estou comendo, publicações que não existem nas minhas outras redes. No Stories eu publico 'bobagens': Publico quando estou no Karaokê, quando ganho um presente, as brincadeiras de minha gata. A relação que tenho com o 
Stories, então, é outra. Por que eu tento postar nele coisas que não serviriam para o público ter permanentemente acesso. Então, são coisas que vão ficar ali só 24 horas e por causa desse recurso de fugacidade eu me dou alguma 'licença poética' para postar 'besteiras' (D)

O fato das postagens só durarem 24 horas provoca uma liberdade maior para publicar, sem muitos filtros e regras, o que se deseja. Assim, os professores apresentam seus cotidianos incessantemente e, por isso, estão sempre conectados, hiperconectados. Consonte Santaella (2007), as pessoas deixam de estar conectadas para serem conectadas. E os professores, alwayson, podem, além de apresentar suas vidas cotidianas, pensar possibilidades pedagógicas por meio da função Stories.

Publicar, interagir durante o devir da vida diária, ubiquamente, na fluidez do instante seduz os professores. Todavia, as mesmas funcionalidades que promovem estas trocas efêmeras sobre os espetáculos cotidianos podem possibilitar outros usos, especialmente, em âmbito pedagógico. Os entrevistados acreditam que a função Stories pode corresponder a um ambiente propício para práticas pedagógicas pelas peculiaridades especificamente a memória efêmera e por já ser um ambiente atrativo para jovens estudantes.

Acho que essa é mais uma ferramenta educacional extraordinária, pois atende às demandas modernas de agilidade. Porém, são superficiais. Sendo assim, vejo essa ferramenta como uma facilitadora dos processos pedagógicos. (C)

Olha, eu já usei o snapchat para fins educativos e uso o WhatsApp. Inclusive eu sai do Android para o IOS devido a promessa de amigos de que não travava e tal, pra poder potencializar os usos desses ambientes em sala de aula. Eu percebi que sala de aula é muito pouco tempo para que os alunos aprendam, se interessem pelos estudos e que o uso deste app é extensivo entre eles então não podia ficar de fora. Orientação, avaliação, atividades de áudio e vídeo em lingua estrangeira vão muito bem com esse recurso. E o melhor, o registro fica muito personalizado e por vezes mais confortável para eles. Vejo este recurso como aliado sim. (A) 
No início eu não postava nada no Stories, mas depois comecei porque vi que as pessoas estavam tentando interagir nele mais em tempo real. Então eu gostei, eu tenho pensado em produzir conteúdos para o Stories, eu tenho pensado em produzir mais coisas direcionadas para esse recurso. Agora eu gosto deste tipo de comunicação efêmera, eu acho que é bem contemporânea é bem líquida, eu gosto, é bom pensar no permanente, mas é bom pensar no fugaz também. E em âmbito educacional, eu acho que têm muitas possibilidades pedagógicas: dicas para os alunos, você pode ir além do que está sendo estudado, pode aparecer rapidamente para mostrar o que está lendo, comentar brevemente um conteúdo, mandar coisas interessantes, falar sobre músicas. Dá para fazer parte do contexto educacional sim. (D)

Para os professores, então, é possível, de maneira complementar, superficial ou como atividade efetiva, utilizar a função Stories. A ideia é explorar a efemeridade do recurso para promover práticas mais condizentes com a educação na cibercultura. Usufruir das linguagens hipermidiáticas, da ubiquidade, da memória de duraçáo de 24 horas, da velocidade dos fluxos de informaçóes para produzir conhecimentos. De acordo Souza e Couto (2016, p. 34):

Essa circulação sideral das mensagens e dos saberes pode, em algumas situaçóes específicas, abrir mão dos registros tradicionais, afinal apagar, desaparecer e esquecer também são dimensôes importantes do ensinar e aprender, são dimensóes importantes das relaçóes humanas, do viver em fluxo.

As memórias efêmeras que pautam este recurso podem, portanto, promover processos de ensino-aprendizagem mais espontâneos, criativos, participativos, sobretudo, fluir tranquilamente na correnteza das transformaçóes atuais. 


\section{Conclusóes}

Açóes, pensamentos, acontecimentos e sentimentos fazem parte do viver das pessoas e, a depender das circunstâncias, após o fato ou ação consumados, deseja-se lembrar ou esquecê-los para a plena atividade da memória e da vida. A dualidade, desta forma, entre lembrança e esquecimento, que compóe a memória do sujeito e a memória da sociedade, está presente em todas as situaçóes e provoca tensões sobre o que deve ser preservado ou não. Hoje, na cibercultura, existe também uma memória digital, que transcende a humana, porque caso o indivíduo esqueça completamente o que disse ou o que publicou, as memórias dos dispositivos tecnológicos e, principalmente, da internet, podem guardar por tempo indeterminado e lembrar em momento posterior, de maneira muitas vezes até inconveniente, o que se desejava manter no esquecimento.

A partir destas compreensóes é possível alcançar um conjunto de conclusóes das quais destacamos duas: a primeira é de que para o contexto de trocas ininterruptas, de espetáculo da vida cotidiana da era da mobilidade, o excesso de memória pode comprometer os usuários, pode provocar problemas e, sobretudo, inibir as interações constantes. Por isso, a função Stories é relevante, já que se constitui como espaço para o esquecimento no momento ou dia seguinte. Assim, deixa os usuários mais livres para publicar rotinas ou até mesmo irrelevâncias sem o temor da permanência na memória e, consequentemente, de posteriores cobranças. Deste modo o esquecimento e as memórias efêmeras apresentam-se como imprescindíveis na atual configuração da cibercultura.

Uma segunda conclusão é que a função Stories do WhatsApp pode fazer parte de determinadas práticas pedagógicas de professores. Elaborar, motivar usos deste recurso no cotidiano escolar para promover a criatividade, a participação, a interatividade dos estudantes e professores na lógica e na magia do instante. Por que assim como os registros e memórias permanentes são indispensáveis para os 
processos de ensino-aprendizagem, as efemeridades são essenciais para provocar pensamentos mais livres e espontâneos.

Além do fato de que as redes sociais e os aplicativos são o habitat das gerações que estão presentes nas escolas. Professores podem e devem se apropriar, interagir, trabalhar e se divertir com os alunos, narrando e apreciando histórias no prazo máximo de 24 horas. Entre o lembrar e o esquecer, vivemos o desafio de ensinar a aprender na magia do instante das nossas comunicaçóes ubíquas.

\section{Referências}

ARAÚJO, P. C.; BOTTENTUIT JÚNIOR, J. B. O aplicativo de comunicação Whatsapp como estratégia no ensino de filosofia. Revista Temática, Salvador, Ano XI, n. 2. Fev. 2015. Disponível em: <http:// periodicos.ufpb.br/ojs2/index.php/tematica>. Acesso em: 12 jun. 2017.

BORGES, Jorge Luis. Ficciones. Buenos Aires: Aliança Editorial, 1997.

'CADÊ MEU STATUS?': As pessoas estão bem confusas com a atualização do WhatsApp. HuffPost Brasil. 23/02/201.

Disponível em: <http://www.huffpostbrasil.com/2017/02/23/ cade-meu-status-as-pessoas-estao-bem-confusas-com-aatualiza_a_21720153/>. Acesso em: 12 jun. 2017.

CAPELAS, Bruno. Até o fim de 2017, Brasil terá um smartphone por habitante, diz FGV. LINK. 19/04/2017. Disponível em: <http://link.estadao.com.br/noticias/gadget, ate-o-fim-de-2017brasil-tera-um-smartphone-por-habitante-diz-pesquisa-dafgv,70001744407>. Acesso em: 8 jun. 2017.

CHARTIER, Roger; CHARTIER, Anne-Marie.Novas tecnologias - ler e escrever, aprender e apagar. In: ROSING, Tania Mariza 


\section{Kuchenbecker (Org.). Literatura e identidade na era da}

mobilidade. Passo Fundo: Universidade de Passo Fundo, 2016.

COUTO, Edvaldo Souza. Pedagogias das conexōes: compartilhar conhecimentos e construir subjetividades nas redes sociais digitais. In: PORTO, Cristiane; SANTOS, Edméa (Org.). Facebook e educaçáo: publicar, curtir, compartilhar. Campina Grande: EDUEPB, 2014.

\section{FUNÇÃO STATUS DO WHATSAPP atinge 175 milhôes}

de usuários diários e ultrapassa Snapchat: Novidade do app de mensagens, muito parecido ao rival, chega à marca menos de três meses após seu lançamento. G1. 04/05/2017. Disponível em: < https://g1.globo.com/tecnologia/noticia/funcao-status-dowhatsapp-atinge-175-milhoes-de-usuarios-diarios-e-ultrapassasnapchat.ghtml>. Acesso em: 12 jun. 2017.

GOMES, Helton Simôes. Criado em 2009, WhatsApp cresceu mais rápido que Facebook em 4 anos: 450 milhôes usam o app; aos 4 anos, site era usado por só 145 milhóes. Facebook anunciou compra do aplicativo WhatsApp por US\$ 16 bilhóes. G1 Sáo Paulo. 20/02/2014. Disponível em: <http://g1.globo.com/tecnologia/ noticia/2014/02/criado-em-2009-whatsapp-cresceu-mais-rapido-quefacebook-em-4-anos.html>. Acesso em: 11 jun. 2017.

KURTZ, João. Facebook chega a 1,8 bilhão de usuários ativos; foco é vídeo ao vivo. TechTudo. 03/11/2016. Disponível em: < http://www.techtudo.com.br/noticias/noticia/2016/11/facebookchega-18-bilhao-de-usuarios-ativos-foco-e-video-ao-vivo.html> . Acesso em: 9 jun. 2017.

MARTINS, Nayara Santana; CLAUDIO, Elexsandra Maria Martins. O uso do WhatsApp na educação: as visōes dos 
licenciandos da Universidade Federal do Acre. Anais do Simpósio Linguagens e Identidades da/na Amazônia Sul-Ocidental, n.1, 2016. Disponível em: <http://revistas.ufac.br/revista/index.php/ simposioufac/article/viewFile/906/503 >. Acesso em: 13 jun. 2017.

MINAYO, Cecília; GOMES, Suely. Pesquisa social: teoria, método e criatividade. Petrópolis: Vozes, 2009.

PRADO, Jean. Os números gigantes do WhatsApp: 1 bilhão de usuários, 42 bilhóes de mensagens por dia. Tecnoblog. 2015. Disponível em: <https://tecnoblog.net/191024/numeroswhatsapp-1-bi-usuarios/ >. Acesso em: 9 jun. 2017.

SANTAELLA, Lucia. Linguagens líquidas na era da mobilidade. São Paulo: Paulus, 2007.

SANTAELLA, Lucia; LEMOS, Renata. Redes sociais digitais: a cognição cognitiva do Twitter. São Paulo: Paulus, 2010.

REBOUÇAS, C.; MENEZES. J. E, Snapchat: o imediatismo imagético e os laços afetivos. Intercom - Sociedade Brasileira de Estudos Interdisciplinares da Comunicação XXXIX Congresso Brasileiro de Ciências da Comunicação - São Paulo, 2016. Disponível em: <http://portalintercom.org.br/anais/nacional2016/ lista_area_IJ-DT5.htm>. Acesso em: 25 maio 2017.

RIBEIRO, José Carlos; FALCÃO, Thiago; SILVA, Tarcízio. Mídias sociais: saberes e representaçóes. Salvador: EDUFBA, 2012.

SIBILIA, Paula. O universo doméstico na era da extimidade:

Nas artes, nas mídias e na internet. Revista ECO-Pós, v.18, n.1, p.133-147, 2015. 
SOUZA, Joana; COUTO, Edvaldo. Snapchat: viver e aprender em meio a mensagens autodestrutivas. In: COUTO, E.; PORTO, C; SANTOS, E. App-learning: experiências de pesquisa e formação. Salvador: EDUFBA, 2016.

WHATSAPP BLOQUEADO: Relembre todos os casos de suspensão do app. Determinação da Justiça do Rio é a quarta tentativa de bloquear WhatsApp. Operadoras de telefonia já foram notificadas para suspender acesso ao app. G1 Sáo Paulo. 19/07/2016. Disponível em: <http://g1.globo.com/tecnologia/ noticia/2016/07/whatsapp-bloqueado-relembre-todos-os-casosde-suspensao-do-app.html>. Acesso em: 11 jun. 2017. 


\title{
WHATSAPP: CENÁRIO PARA DISCUSSÓES E REFLEXÓES SOBRE \\ A PERMISSIVIDADE E LIMITE \\ DA INTERAÇÃO DE CRIANÇAS E ADOLESCENTES COM O UNIVERSO DIGITAL
}

\author{
Lynn Alves - UNEB e Centro Universitário SENAI - CIMATEC \\ Velda Torres - UFBA e UCSAL
}

\section{Introdução}

Os artefatos sociotécnicos contemporâneos aqui compreendidos como produçôes tecnológicas criadas dentro de uma sociedade que atende e cria novas demandas e necessidades no cotidiano da vida humana, vêm provocando mudanças na forma das pessoas se organizarem, acessarem informaçóes e produzirem novos conhecimentos.

Nesse contexto, destacamos a interface comunicacional WhatsApp, criada em 2009, por Jan Koum e Brian Acton e que em janeiro de 2017 já tinha 1,200 milhão ativo em nível global (JASON, 2017). Este software de comunicação que tem a origem do seu nome a partir do trocadilho inglês "What's Up" vem sendo usado por mais de 180 países e desde 2014 foi comprado pelo Facebook e está disponível gratuito para as plataformas IOS, Android, Windows e Windows Phone, BlackBerry e Nokia e também para computadores (SIMPLES..., 2017). 
Em 7 de junho de 2017 (às 23h30), foi exibida pela GloboNews uma entrevista com Brian Acton que esteve no Brasil para responder aos questionamentos do Supremo Tribunal Federal sobre o acesso aos dados de determinados usuários do Whats $A p p$ que realizam atividades criminosas. Durante a entrevista realizada por $\mathrm{Mu}-$ rilo Salviano, Acton declarou que o Brasil é o segundo maior mercado que utiliza este software de comunicação, tendo 120 milhóes de usuários, mais da metade da população do nosso país, estando atrás apenas da Índia. Segundo Acton, as mensagens são criptografadas e apenas quem envia e recebe a mensagem tem acesso ao teor das informaçóes enviadas, pois a empresa protege e preserva a privacidade dos usuários.

Essa polêmica que vem desde 2015 colocando o WhatsApp na mira da justiça ainda não chegou ao fim, mas constatamos a cada dia que esta mídia mudou a forma das pessoas utilizarem seus telefones móveis, especialmente os smartphones ${ }^{1}$. Maquininhas que atuam hoje como computadores na palma da mão e nos quais acessamos nossos arquivos nas nuvens computacionais, gerenciamos nossos e-mails e processos comunicacionais. Pessoas de distintas faixas etárias e níveis socioeconômicos e culturais interagem com seus smartphones e interfaces como o Facebook, messeger e o WhatsApp.

No relatório Growing Up Online - What kids conceal (2016), da Kaspersky Lab, publicado em 2016, relativo à pesquisa realizada nos Estados Unidos, França, Rússia, Itália, Espanha, Inglaterra e Alemanha, com 3.780 famílias, tendo como sujeitos uma criança e um pai por família, utilizando um instrumento on-line, foi constatado que $33 \%$ das crianças e adolescentes entrevistados, na faixa etária de 8 a 16 anos, utilizam mensagens instantâneas como WhatsApp.

1 A diferença básica entre um celular e um smartphone refere-se à capacidade multitarefa do segundo que além de ser multimídia permite o acesso a internet, redes sociais e também baixar aplicativos, jogar, entre outras possibilidades. Contudo, neste artigo estaremos utilizando os termos como sinônimos por conta das falas dos pais que foram sujeitos da pesquisa aqui apresentada. 
Deste percentual, 32\% são meninos e 38\% são meninas. Na Tabela abaixo, percebemos que as crianças que estão nas séries iniciais são as que mais utilizam, indicando que cada vez mais precocemente estes sujeitos interagem com este universo digital.

Usuários de WhatsApp

\begin{tabular}{|c|c|c|}
\hline $8-10$ anos & $11-13$ anos & $14-16$ anos \\
\hline $49 \%$ & $43 \%$ & $39 \%$ \\
\hline
\end{tabular}

Fonte: Adaptado de Growing Up Online (2016).

Estes dados também podem ser constatados no Relatório Adolescentes, Pré-adolescentes e Tecnologia (Teens, Tweens and Technology Report) (McAFEE, 2015), pesquisa que envolveu crianças e adolescentes australianos na faixa etária de 8 a 17 anos indicou que estes sujeitos quando estão na internet utilizam sites de relacionamento, a exemplo do Facebook (93\%), YouTube (87\%) e WhatsApp (79\%). Novamente percebemos que apesar de existirem restriçóes etárias de uso, elas não são respeitadas.

E por fim, o relatório do Centro Regional de Estudos para o Desenvolvimento da Sociedade da Informação (Cetic.br), publicado em 2017 pelo Comitê Gestor da Internet, indica que crianças de 9 a 10 anos declaram utilizar o Facebook (50\%) e WhatsApp (47\%) e em contraponto, os adolescentes na faixa etária de 15 a 17 anos registraram que possuem conta no Facebook (92\%) e WhatsApp (82\%), do total de 3.068 dos entrevistados no território brasileiro, quando estão na internet, enviam mensagens instantâneas. $\mathrm{E}$ quem são esses sujeitos? 


\section{Crianças e adolescentes na internet}

PROPORÇAO DE CRIANÇAS E ADOLESCENTTES QUE ACESSARAM A INTERNET NOS ÚLTIMOS TRĒS MESES (2015) Percentual sobre o total de crianças e adolescentes de 9 a 17 anos

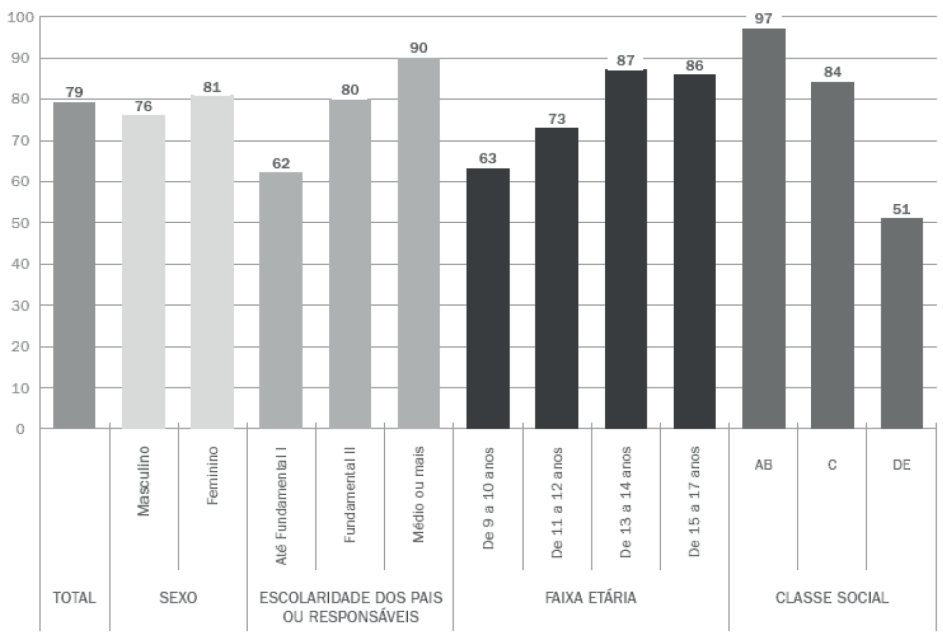

Fonte: CETIC.Br.

Estes dados ratificam que tanto no Brasil quanto fora dele, temos uma geração que interage intensamente com o universo digital e a escola? Bem, a escola continua alheia a tudo isso, inclusive criando proibiçóes que vetam o uso destes artefatos tecnológicos nos espaços escolares, pois embora os professores e o corpo técnico administrativo das escolas utilizem para se comunicar e trocar informaçóes muitas vezes de forma lúdica, não conseguem atribuir sentidos pedagógicos para estas tecnologias, sendo mais fácil proibir o uso e a presença destes aparatos tecnológicos nos cenários escolares.

Assim, como os docentes não conseguem entender a interação intensa dos seus alunos, os pais também não, inclusive aqueles que são pesquisadores da área.

É neste cenário que se inscreve este artigo que tem o objetivo de analisar as discussōes e angústia dos pais pesquisadores da área de cultura digital, por meio da mediação do WhatsApp. 
Estes sujeitos membros do Centro de Pesquisa e Desenvolvimento Comunidades Virtuais (CV) da Universidade do Estado da Bahia, que tem como um dos seus objetivos formar novos pesquisadores na área de cultura digital, fazem parte de um grupo no WhatsApp, criado em 28 de março de 2014 e com 58 participantes, sendo que 16 são mães de crianças e adolescentes na faixa etária de seis meses a 18 anos; e seis pais.

O grupo possui uma dinâmica muito intensa e especialmente nos dias 05/07/2016 e 14/11/2016 discutiu sobre como se sentem ao ter que estabelecer limites para a interaçáo dos seus filhos com o universo digital. A segunda discussão foi fomentada pela publicação do manual de Orientação da Sociedade Brasileira de Pediatria sobre a saúde de crianças e adolescentes na era digital, publicada no dia 01/10/16. É importante ressaltar que as questóes que tensionam o relacionamento pais, filhos e tecnologias nesse grupo são frequentes, considerando a especificidade das linhas de pesquisa vinculadas ao $\mathrm{CV}$.

Mas o debate limita-se ao pronunciamento de nove pais que participaram intensamente das discussóes, sendo que três deles são do sexo masculino. Os demais membros do grupo adotam a postura de voyers, acompanhando o que é dito, sem se pronunciar, apenas observando. Estes sujeitos têm participação ativa em outros temas que emergem no grupo.

Tomaremos estes discursos, considerando a intensidade das discussóes ocorridas nos dias indicados acima, como objeto deste capítulo, não apenas para evidenciar as angústias dos pais em torno do seu papel diante do desejo de interação frequente dos filhos com as tecnologias digitais, especialmente as redes sociais, softwares de comunicação instantânea, jogos, aplicativos entre outras interfaces, mas especialmente para analisá-las e apontar o What$s A p p$ como um espaço para reflexão e formação de professores e pesquisadores. 


\section{Pais, filhos, pesquisadores e tecnologias}

A nossa imersão no universo da cultura digital, seja como docentes, palestrantes e pesquisadores é marcada pela inquietação dos pais e professores que não sabem como devem se comportar frente à intensa interação dos seus filhos com o universo digital, sentindo-se muitas vezes impotentes para estabelecer os limites, especialmente porque são usuários dos dispositivos móveis e seus aplicativos e normalmente são confrontados pelos filhos quando restringem o uso.

Um uso que não é apenas de meros consumidores, mas de protagonistas, se autorizando a criar e compartilhar suas ideias e produçóes. Desta forma, compreendemos que a interação com estes dispositivos e aplicativos vai além de uma perspectiva instrumental, mas se constrói de forma inventiva e criativa (ALVES, 2016).

Nesse contexto emerge o aplicativo WhatsApp que já mobiliza adultos e crianças para atribuírem outro sentido aos aparelhos telefônicos. A propagabilidade discutida por Jenkins, Green e Ford (2014) ganha uma dimensão diferenciada, na medida em que os usuários, independente da faixa etária, socializam mensagens, notícias, vídeos, diferentes discursos, muitas vezes sem analisar sua veracidade.

Para os autores, a propagabilidade

reconhece a importância das conexóes sociais entre os indivíduos, conexóes cada vez mais visíveis (e amplificadas) pelas plataformas da mídia social. Essa abordagem pode ainda incluir mensuraçóes quantitativas de frequência e da amplitude dos deslocamentos de conteúdo, mas torna importante ouvir ativamente as maneiras pelas quais os textos de mídia são usados pela audiência e circulam por meio das interaçóes entre as pessoas. (JENKINS; GREEN; FORD, 2014, p. 29). 
É nessa direção que foi realizada a escuta sensível (BARBIER, 2002) dos pesquisadores e pais do CV, no grupo do Whats App durante as discussóes sobre até onde deve ir a proibição e limites do uso das tecnologias digitais por seus filhos. Para realizar a análise destas interaçóes textuais, foram selecionados os dias 05/07/16 e 14/11/16 conforme descrito anteriormente.

As telas do aplicativo foram printadas e posteriormente digitadas as falas em dois quadros, separando cada sujeito e dia da intervenção. Posteriormente, analisamos os dados produzidos e estabelecemos os aspectos para análise, considerando o que foi identificado.

$\mathrm{O}$ primeiro aspecto refere-se ao lugar que a tecnologia, especialmente os smartphones e tablets, ocupa na vida dos filhos dos sujeitos.

Os pesquisadores Gardner e Davis (2014) realizaram uma pesquisa analisando a interação dos jovens com os aplicativos, tomando como referência pessoas que nasceram no século XX e que nasceram no século seguinte. Para os autores, as pessoas têm sentimentos fortes sobre tecnologia e sua influência sobre os filhos, a sociedade e sobre si. Além disso, para Gardner e Davis existe um fascínio das pessoas em contemplar como a nova geração se difere das anteriores ${ }^{2}$.

$\mathrm{Na}$ pesquisa realizada, os aplicativos apareceram como uma das metáforas para os principais temas que emergiram durante a investigação. Para compreender essa metáfora, Gardner e Davis (2014) introduziram três conceitos-chave: aplicativo: mentalidade (app-mentality), habilitação (app-enabling) e dependência (app-dependence). O primeiro refere-se aos aplicativos utilizados para executar tarefas discretas, como a localização de um restaurante, comprar uma peça de roupa, ou falar com um amigo, a exemplo do

2 People hold strong feelings about technology and its influence on our children, our society, ourselves. Coupled with this is people's fascination in contemplating how the new generation differs from its predecessor (GARDNER; DAVIS, 2014, p. ix). 
WhatsApp, caracterizando-se como uma maneira algorítmica de pensar, perguntas e desejos que exigem satisfação definitiva e imediata.

Este tipo de aplicativo são caracterizados por ícones ou marcas que favorecem uma rápida identificação, evitando ambiguidades ou incertezas, como o carrinho de compras da Amazon, o pássaro do Twiter ou o balão com o fone de telefone do WhatsApp. Os pesquisadores registraram que estes tipos de aplicativos são utilizados pelos adolescentes, delineando seus perfis nas mídias sociais (2013, p. xii).

Gardner e Davis (2013, xiii) avançam distinguindo os app-habilitação e app-dependência:

Nós usamos aplicativos de habilitação para descrever situaçóes em que as pessoas usam seus dispositivos e aplicativos como trampolins para novas experiências e áreas de conhecimento, relacionamentos significativos e expressão criativa. Em contraste, o aplicativos de dependência surgem quando a tecnologia é usada como ponto de partida, ponto final e todo o resto - em outras palavras, quando os indivíduos olham para seus aplicativos e dispositivos antes de olhar para dentro de si mesmos ou chegarem a um amigo. ${ }^{3}$

A perspectiva apresentada pelos autores acima contribuiu para evidenciar na fala de todos os sujeitos escutados na nossa pesquisa que estes artefatos (os apps) se constituem em objeto de desejo para seus filhos, transitando entre os três conceitos apresentados, gerando preocupaçóes que passam por vários questionamentos que

3 We use app-enabling to describe situations in which youg people use their devices and apps as springboards to new experiences and areas of knowledge, meaningful relationships, and creative expression. In contrast, app-dependence arises when technology is used as a starting point, endpoint, and everything in between - in other words when individuals look to their apps and devices first before looking inside themselves or reaching out to a friend. 
serão indicados aqui, a exemplo de "Qual a idade certa para uma criança ter um celular (smartphone)?

Uma das mães - aqui denominada Raio de $\mathrm{Sol}^{4}$, deu o primeiro celular ao seu filho aos oito anos (seus filhos têm 6 , menina e 10 anos, menino). Já Zelda tem um filho de 6 anos que já tem celular e tablet e utiliza o primeiro para se comunicar com a máe e avó. Esta mãe sempre faz indicaçóes de textos, aplicativos e jogos no grupo, inclusive foi quem compartilhou o Manual de orientação que fomentou a discussão do dia 14/11/16.

Mestre Yoda, um dos pais do grupo, tem uma filha de 8 anos que interage com aplicativos, youtube, jogos e desde os três anos utiliza o smartphone do pai e aos 6 ganhou o seu, tendo inclusive Whats App. Segundo o pai, a filha desenvolveu um senso crítico que o surpreende muitas vezes.

Super Mário, outro pai de um menino de 6 anos, resolveu não limitar a interação do filho com as tecnologias.

Kratos, pai de dois filhos, um menino e uma menina, com idades de 12 e 14 respectivamente, chegou ao consenso com os filhos que só teriam aparelho celular a partir dos 10 anos.

É importante ressaltar que os três pais também interagem desde pequenos com os jogos digitais e são pesquisadores dessa área.

Em contraponto, duas mães com filhos com idades entre 2 a 9 anos decidiram esperar mais tempo para dá um celular aos filhos, pois consideram que eles ainda náo têm maturidade.

Virginiana deu o celular para seu filho de 14 anos, quando ele completou 13.

A pesquisa realizada pela Kaspersky, já citada anteriormente, aponta que

as razóes para essa crescente utilização dos smartphones refere-se ao fato de ser agora mais barato

4 Para preservar a identidade dos sujeitos, utilizaremos nomes fictícios criados apenas para este capítulo pelas autoras. 
com maior capacidade de armazenamento e com telas maiores e com mais funcionalidades, possibilitando realizar várias açóes. Mas acima de tudo são pequenos e portáteis permitindo que usuários de qualquer idade possa levar para qualquer lugar, tornando-o essencial para sua vida online, levando-os para todos os lugares. (GROWING..., 2016, p. 5). ${ }^{5}$

Para os pesquisadores, a condição generalizada do século 21 que é o medo de perder (em inglês FOMO - fear of missing out) se combina com a angústia e o desejo dos adolescentes de estar perto dos amigos em todos os momentos, tornou os smartphones irresistíveis, pois podem está all always conectados aos seus amigos (GROWING..., 2016, p. 5). ${ }^{6}$

O segundo aspecto pontuado pelos pais é a segurança, isto é, como garantir que as crianças e adolescentes estarão protegidos nas redes sociais, inclusive no WhatsApp, considerando que não se pode ser onipotente e onipresente, monitorando todos os conteúdos, acessos e conversas. As estratégias de controles variam para cada um dos sujeitos, ou seja, de não usar o WhatsApp no final de semana "para ter respaldo para mediar o tempo de uso no dispositivo móvel por parte dos filhos” (RAIO DE SOL).

5 Traduçâo livre das autoras "The reasons for this growing use include the fact that smartphones are now cheaper, with larger screens and memories and greater functionality - so they can do more. But, most of all they are small and portable and allow users of any age to carry their indispensable online life withthem wherever they go. The widespread, 21st century condition: FOMO ('fear of missing out'), combined with teenage angst and a natural desire to be close to one's friends at all times, make connected phones irresistible companions".

6 Traduçấo livre das autoras "The reasons for this growing use include the fact that smartphones are now cheaper, with larger screens and memories and greater functionality - so they can do more. But, most of all they are small and portable and allow users of any age to carry their indispensable online life withthem wherever they go. The widespread, 21st century condition: FOMO ('fear of missing out'), combined with teenage angst and a natural desire to be close to one's friends at all times, make connected phones irresistible companions". 
Yara declara que "a questão é a porta aberta da internet e a (in)maturidade da filha para passar por determinadas situaçóes".

Princesa registra que "não vê maldade no filho para saber separar as situaçóes. E que ela na sua infância foi muito aterrorizada pela mãe com recomendaçôes do tipo: não fale com estranhos, não aceite nada de ninguém...”.

A Safernet é uma organização não governamental preocupada com os direitos humanos e com a ética no ciberespaço, tem como um dos objetivos "transformar a Internet em um ambiente ético e responsável, que permita às crianças, jovens e adultos criarem, desenvolverem e ampliarem relaçóes sociais, conhecimentos e exercerem a plena cidadania com segurança e tranqüilidade"7. Esta ONG tem tido um papel importante em diferentes espaços, inclusive nos escolares e acadêmicos, discutindo e orientando crianças, adolescentes, pais e especialistas para o uso seguro da internet.

A discussão que ocorreu no dia 14/11/2016 sobre o manual de orientação para Saúde de crianças de adolescentes na era digital envolveu seis mães e dois pais. $\mathrm{O}$ referido documento tem o objetivo de orientar pais, professores e especialistas sobre o uso da tecnologia por parte de crianças e adolescentes sob o ponto de vista médico. Para os autores do documento "[...] tanto os pais como os educadores nas escolas precisam aprender como exercer esta mediação e serem alertados sobre os riscos e os limites necessários para assumirem esta responsabilidade" (MANUAL..., 2016, p. 2). Contudo, o referido documento só enfatiza os aspectos negativos, como dificuldades de socializaçáo e escolares, aumento da ansiedade, cyberbullying, problemas de alimentação e de sono, sedentarismo, dentre outros, chegando ao ponto de indicar uma "dieta midiática".

7 Disponível na URL: <http://www.safernet.org.br/site/institucional.> Acesso em: 14 jun. 2017. 
Diante do conteúdo do documento, os pais reagiram, buscando um ponto de equilíbrio para o que foi prescrito, já que era um tema que consideravam "um território de angústia e dúvidas" (KRATOS).

Yara questiona:

Como a autoridade médica prevalece sobre a autoridade familiar? Pais e mães precisam que alguém, no caso o médico, diga quanto tempo seu filho pode ficar na internet? Se a família não assume seu papel, algo fica fora de ordem, por que a autoridade médica é homogeneizante. O documento apresentado tem uma boa intenção. Não questiono o documento, que apresenta alguns equivocos no meu olhar de educadora, mas traz reflexóes importantes sobre esse fenômeno. O que questiono é justamente onde nós, família, e ai não só os pais e mäes, mas toda a família, está querendo para chegar ao ponto de delegar a outras pessoas, responsabilidades que são nossas?

A fala de Yara que se prolonga em um post seguido no WhatsApp aponta vários aspectos, inclusive, indicando referências, a exemplo de Bauman (2000) e McGonigal (2012) para respaldar suas ponderaçôes. No discurso acima, podemos constatar um ponto que vai se repetir na fala de outros pais, que se referem a responsabilidade do controle do tempo e uso, isto é, quem efetivamente decide? Devemos ouvir as crianças, mas os adultos é quem decidem? Outro ponto interessante refere-se ao fato de que não existe uma única forma, não existem prescriçóes médicas ou sociais únicas, não devemos homogeneizar, pois cada família irá decidir, considerando sua cultura, valores, entre outros aspectos fundantes na formação de novos sujeitos.

Para Princesa, o filho dela precisa ouvir um não:

às vezes ele tenta me testar... vai querendo atingir meu limite. O problema é que nós (ou pelo menos, muitos de nós) sabemos os limites de tempo para cada coisa e que se náo cumprirmos os prazos seremos punidos. Eles, enquanto criança, não possuem essa noçáo. Por isso, a importância do nosso papel de intervenção. Não existe fórmula mágica. Cada pai e mãe terá que dosar essa medida de acordo com a sua realidade. 
Zelda reforça as palavras de Princesa, sobre a importância do limite, ampliando para o adulto. "Infelizmente não podemos dedicar muito tempo aos nossos filhos. Vejo também que muitos adultos não conseguem administrar bem seu próprio tempo e limite".

Uma pesquisadora que não é mãe também enfatiza que "vivemos a internet de todas as coisas". Falamos das crianças. E nós, qual o limite? Quanto tempo ficamos sem olhar o zap?8

O controle inibitório é uma habilidade executiva fundamental no processo de desenvolvimento, pois nos prepara para viver na sociedade, respeitando o nosso limite e o limite do outro. Para Dias e Seabra (2013, p. 207):

A inibição é grandemente relevante em inúmeras tarefas e situaçóes do dia a dia, pois provê ao indivíduo o controle de seus processos cognitivos, emocionais e comportamentais, suplantando o controle por eventos externos, reaçóes emocionais automáticas, tendências prévias ou habituais. Dessa forma, o indivíduo se torna capaz de inibir impulsos, comportamentos inadequados, respostas automáticas ou prepotentes, assim como estímulos irrelevantes ou distratores, de modo que possa ponderar e pensar antes de emitir uma resposta.

O controle inibitório é uma das habilidades executivas, junto com a flexibilidade cognitiva e memória operacional fundamental para o desenvolvimento do sujeito e começa a ser construído a partir dos 12 meses de idade, atingindo seu ápice no final da adolescência e declínio na terceira idade. Assim, esse limite discutido pelos pais, no caso desse capítulo, em relação à interação com as tecnologias deve ser estimulado nos distintos espaços de aprendizagem nos quais os sujeitos estejam imersos a fim de que seja internalizado pelas crianças e adolescentes.

8 Os sujeitos da pesquisa utilizam as expressôes Zap e Wpp para se referir ao WhatsApp. 
Ainda em relação aos limites, os pais do grupo questionam o papel do estado, definindo o que pode ou não pode ser feito dentro das suas casas, mas defendem uma liberdade assistida junto às crianças, assim como a sistematização de recomendações.

Esses pequenos e significativos recortes das preocupaçóes dos pais em relação à interação dos filhos com as tecnologias, apesar de serem pesquisadores da área, sinalizam a importância de temos um fórum de debate contínuo, potencializando os espaços criados pelos grupos no WhatsApp para compreendê-lo como um âmbito de aprendizagem no qual se pode aprender com a escuta do outro, discutir e construir juntos uma trilha que contemple a diferença, a escuta sensível e valorize a interação e construção mediada pelas tecnologias sem posturas apocalípticas (ECO, 2015).

A análise das falas dos pais permitiu identificar pontos de tensionamento, como por exemplo: princípios que norteiam a educação dos filhos - entre a reproduçáo de modelos e a construção de práticas que respeitem a individualidade dos filhos.

As discussóes possibilitaram que mães como Princesa e Virginiana relembrassem suas infâncias:

Meninas lendo e pensando. Sabe.. quando eu era pequena minha mäe estabelecia limites... muitos... quanto tempo no quintal, jogando bola, baleado, fazendo comidinha...pois não poderíamos ficar o "tempo todo brincando"”. Eu morria de ansiedade pela hora em que ia brincar na praça com a galera. (VIRGINIANA).

Outro ponto refere-se às práticas de negociaçáo - cumprimento de rotinas que levam ao uso

Mario Bros declara que resolveu não limitar e não colocar regras para o uso da tecnologia. Contudo, "estabelece outras regras a exemplo de estudar e fazer outras atividades e essas regras acabam por estabelecer limites para a utilização das tecnologias. E eu não abro mão da fiscalização". 
O brincar na contemporaneidade foi outro ponto enfatizado pelos pais, inclusive, estabelecendo relação com as formas de brincar na infância deles.

Eu fico me perguntando por que resgatar brincadeiras antigas. Brincadeiras que só fazem sentido dentro do contexto cultural daquela geração. Eu fico realmente pensando e tentando näo ser preconceituosa. A escola de Mafalda (tem 9 anos) fez isso este ano. E eu perguntei: qual o objetivo? A escola me disse que era para resgatar a cultura dos pais e dos avós, por que hoje em dia as crianças não brincam mais como antigamente. Eu disse: é óbvio que não. Assim, como nós não brincamos como nossos avós. A gente sempre ressignifica o brincar... o viver.... eu não entendo por que essa nostalgia. Ai eu perguntei qual o problema com as brincadeiras de hoje em dia? A professora falou da tecnologia e que os pais sempre reclamam e pedem para a escola ajudar. Eu realmente entendi que estamos em uma transição. E não é fácil entender as novas lógicas de viver, de trabalhar, de brincar, assim como nossos avós e pais também não entenderam. (YARA).

Zelda que tem um filho de 6 anos em uma escola particular compartilha o seguinte depoimento: "Tenho observado que a escola de meu filho está organizando um movimento em oposição ao uso das tecnologias digitais, promovendo eventos falando do resgate de brincadeiras antigas e mandando alerta aos pais com o tema".

A fala de Yara e Zelda destaca pontos significativos e que emergem cotidianamente, seja no discurso da mídia, nos dos pais, dos professores e especialista, um saudosismo que visa desqualificar o momento atual, já que não consegue lidar com o novo (que não é tão novo assim).

Como Yara pontuou não é possível pensar no brincar sem atentar para as mudanças culturais, sociais, antropológicas, tecnológicas, por exemplo, que tensionam as relaçóes na sociedade contemporânea.

Outro ponto relevante é a transferência da família para que a escola resolva ou aja nas zonas de tensão nas quais os pais se sentem impotentes para tomar decisóes - a mediação e acompanhamento do acesso dos filhos ao universo tecnológico. 
E ainda o já táo discutido fosso geracional entre a escola professores e alunos. Tal fosso contribui para que a escola seja um lugar de desprazer no qual os docentes não estáo sendo formados para uma sociedade permeada por tecnologias que possibilitam que seus usuários sejam mais que consumidores.

Por que a escola resiste em dialogar com o seu entorno? Uma forma de se aproximar do contexto dos alunos é construindo práticas lúdicas, atentando para suas três dimensóes: reconhecer que o brincar e as atividades lúdicas de maneira geral são criaçôes culturais, produzidas nas relaçôes entre os homens no contexto social; compreender a ludicidade como um estado de ânimo e que se relaciona com a realidade interna do indivíduo; e pensar a ludicidade como princípio formativo que deve está presente no espaço escolar como elemento estruturante para produzir aprendizagens significativas (LEAL; D’ÁVILA, 2013).

Diariamente constatamos a inabilidade da escola lidar com as tecnologias outro aspecto evidenciado nas falas dos pais.

A escola do meu filho proibiu completamente o uso do celular nas dependências da escola. E nem mesmo às sextas (dia livre para levar o brinquedo que quiser) eles podem levar o tablet ou celular. Batman [filho de Princesa] já não levava mesmo porque ele tinha medo de perder ou quebrar. Mas particularmente fiquei arrasada com a iniciativa. Acho que a escola deve criar estratégias para o uso das tecnologias na escola e não proibir. (PRINCESA).

Magali, professora que ainda não é mãe e em diálogo com Princesa, diz: "o problema é que os professores (a grande maioria) não estão preparados para utilizar as tecnologias e por isso é melhor banir. Porque as crianças estáo a léguas de distância no uso".

Princesa ilustra um pouco mais sua relação com a professora de Batman, de uma escola particular, mediada pelo WhatsApp:

Mandei o wpp para a professora dele e recebi a resposta dois ou três dias depois (sabia que ela ia demorar para responder, pois tinha visto o dia da última 
visualização). Eles não estão preparados para o uso das tecnologias e da importância desses dispositivos em sala de aula.

E por onde anda o desejo dos professores? Yara registra ainda que:

Imagino como deve ser dificil a realidade dos professores e a sobrecarga. Mas quando digo que imagino é porque sabemos das dificuldades de incentivos do governo para facilitar o acesso aos dispositivos e a formaçáa dos professores, pois não adianta ter e não usar. Digo isso, porque as escolas particulares cobram uma fortuna dos pais e terminam agindo da mesma maneira que as escolas públicas.

Neto, Versuti e Vaz (2016) descrevem as pesquisas realizadas na Índia, Israel e no Brasil com a mediação do WhatsApp nos ambientes escolares e acadêmicos, apontando limites e possibilidades para compreender este aplicativo como um espaço de aprendizagem que vai além das possibilidades de comunicação (SANTOS; PEREIRA; MERCADO, 2016; KAIESKI; GRINGS; FETTER, 2015; BOUHNIK; DESHEN, 2014).

A importância das discussóes iniciadas no grupo do WhatsApp do CV ratifica a necessidade de ouvir crianças, adolescentes, pais e professores para que juntos possam encontrar caminhos para efetivar a interação dos seus filhos com as tecnologias de forma prazerosa e segura. O nível de reflexão e preocupação evidenciada aqui ratifica que para além de um espaço para comunicação livre para encontrar e falar com amigos e familiares, compartilhando distintas mídias e pontos de vista, o WhatsApp pode se constituir em um espaço formativo para os diferentes temas, interesses e grupos, ratificando a ideia de Lèvy (1998) da construção em tempo real, envolvendo pessoas que estáo em distintos pontos geográficos e com diversas perspectivas podem construir uma inteligência coletiva, centrada nos aforismas indicados pelo autor: ninguém sabe tudo, todo saber está disponível na humanidade e cada um tem um saber. E ainda para Giedd (2012, p. 3): 
Uma das habilidades mais úteis para crianças e adolescentes adquirirem será a habilidade de efetivamente utilizar este universo de informação - para criticamente avaliar os dados, para discernir sinais de barulhos, sintetizar conteúdos, e aplicar tudo isso à resolução de problemas no mundo real? .

Esse é o desafio de pais, educadores e especialistas, permitir que a geração que interage intensamente com as redes sociais e as tecnologias digitais e telemáticas possam: experimentar, construir sentidos e aprender com elas as questóes relacionadas com o uso, segurança e possibilidades de aprendizagem, mas com a interlocução e mediação do adulto, não como um censor, mas um parceiro nessa aventura.

\section{Consideraçóes finais - Encaminhamentos}

A discussão realizada pelos pais pesquisadores da cultura digital nos sinaliza pontos importantes que não podem ser preteridos. Inicialmente é pensar de qual lugar falamos das tecnologias. O que elas sáo e como lidamos com elas. Compreender as tecnologias digitais e telemáticas para além de ambientes determinantes de comportamentos positivos e negativos, mas como espaços de produção e criação nos quais adultos, crianças e adolescentes podem experimentar e criar novas formas de aprender, tendo liberdade para se expressar, interagir e compartilhar diferentes pontos de vista mediado por diferentes linguagens. Contudo, precisamos aprender a lidar com esse universo desterritorializado no qual devem existir limites não apenas de uso, mas de respeitar o outro para ser respeitado, para aprender a conviver com a diferença.

9 "One of the most useful skills for children and adolescents to acquire will be the ability to effectively utilize this universe of information - to critically evaluate the data, to discern signal from noise, to synthesize the content, and to apply it to real-world problem solving”. 
Quando se trata de crianças e adolescentes, o controle é fundamental, mas não de forma autoritária, mas negociado, favorecendo a criação de estratégias de interação e junto construir indicadores que emergem a partir de protocolos culturais, valores, interesses e desejos de cada núcleo familiar, rompendo com a ideia de patologizar o novo, o diferente, o que não conhecemos, mas aprender a interagir com o WhatsApp, por exemplo, para além das questóes comunicacionais, interagindo com os recursos existentes nesse aplicativo para evitar que se torne uma torre de Babel.

E em sintonia com Bouhnik e Deshen (2014, p. 230) concordamos que

se Whats $A p p$ torna-se uma ferramenta comum para professores e alunos em sala de aula, haverá necessidade de mais pesquisas para identificar as propriedades do usuário e a melhor maneira de integrá-lo sem metas educacionais e pedagógicas. Isso exigirá a implementaçáo de uma vasta gama de metodologia de pesquisa qualitativa. Essa pesquisa produzirá inevitavelmente conclusões teóricas e práticas. As entrevistas neste estudo [referem-se a pesquisa realizada em Israel e já indicada anteriormente] foram com estudantes do ensino médio; Pesquisas adicionais devem também envolver escolas de ensino fundamental e universidades. ${ }^{10}$

Assim, o WhatsApp pode se constituir em um espaço de formação e investigação para os docentes e pais discutirem e juntos construírem trilhas de interação seguras, criativas e ricas de sentidos.

10 If WhatsApp becomes a common tool for teachers and students in the classroom, there will be need for further research in order to identify user properties and the best way to integrate them into educational and pedagogical goals. This will necessitate the implementation of a wide range of qualitative research methodology. Such research will inevitably yield both theoretical and practical conclusions. The interviews in this study dealt with high school students; further research should examine junior high and elementary schools and universities as well. 


\section{Referências}

ALVES, Lynn. Práticas inventivas na interação com as tecnologias digitais e telemáticas: o caso do Gamebook Guardiōes da Floresta. Revista de Educaçáo Pública, v. 25, p. 574-593, 2016.

ABREU, Cristiano Nabuco de; EISENTEIN, Evelyn; ESTEFENON, Susana Graciela Bruno. Vivendo esse mundo digital - impactos na saúde, na educação e nos comportamentos sociais. Porto Alegre: ArtMed, 2013.

BARBIER, Rene. A pesquisa-ação. Tradução por Lucie Didio. Brasília: Plano, 2002. (Série Pesquisa em Educação, v.3).

BAUMAN, Zygmunt. Modernidade líquida. Rio de Janeiro: Zahar, 2000.

BOUHNIK, Dan.; DESHEN, Mor. WhatsApp goes to school: mobile instant messaging between teachers and students. Journal of Information Technology Education. Santa Rosa, v.13, p.217-231, 2014. Disponível em: <http://www.jite.org/ documents/Vol13/JITEv13ResearchP217-231Bouhnik0601. pdf>. Acesso em: 15 jun. 2017.

COMITÊ GESTOR DA INTERNET NO BRASIL - CGI.br. Pesquisa sobre o uso da internet por crianças e adolescentes no Brasil [livro eletrônico]: TIC Kids on-line Brasil 2015 / Núcleo de Informação e Coordenação do Ponto BR, [editor]. São Paulo: Comitê Gestor da Internet no Brasil, 2016.

DIAS, Natalia Martins; SEABRA, Alessandra Gotuzo. Funçóes executivas: desenvolvimento e intervenção. Temas sobre desenvolvimento. 2013; v. 19, n.107, p.206, 2012. Disponível em: 
<https://www.researchgate.net/publication/281177320_funcoes_ executivas_desenvolvimento_e_intervencao>. Acesso em: 9 jun. 2017.

ECO, Umberto. Apocalípticos e integrados. São Paulo: Perspectiva, 2015.

GARDNER, Howard; DAVIS, Katie. The app generation. Yale University Press: New Haven and London, 2014.

GIEDD, Jay, N. The digital revolution and adolescent brain evolution. J. Adoles Health, v. 51, n. 2, p. 101-105, 2012.

GROWING UP ONLINE. What Kids. Conceal. Kaspersky Lab, abr. 2016. Disponível em: <https://kids.kaspersky.com/ wp-content/uploads/2016/04/KL_Report_GUO_What_Kids_ Conceal.pdf>. Acesso em: 14 jun. 2017

INTEL SECURITY TEENS, Tweens and Technology Study India. Intel Security. 10/07/2015. Disponível em: <http://apac. intelsecurity.com/digitalsafety/wp-content/uploads/sites/7/2015/10/ Intel-Security_India-Teens'Tweens'Technology-2015-_NationalDatasheet.pdf >. Acesso em 15 jun. 2017.

JASON. Sabe quantos usuários têm WhatsApp em 2017? Como escolher. 2017. Disponível em: <http://www.howtochoosealaptop. com/pt/do-you-know-how-many-users-have-WhatsAppon-2017/>. Acesso em: 1 abr. 2017

JENKINS, Henry; GREEN, Joshua; FORD, Sam. Cultura da conexáo - criando valor e significado por meio da mídia propagável. São Paulo: Aleph, 2014. 
KAIESKI, Naira; GRINGS, Jacques André; FETTER, Shirlei Alexandra. Um estudo sobre as possibilidades pedagógicas de utilização do WhatsApp. Revista Renote: Novas tecnologias na Educação, Porto Alegre, v.13, n.2, p.1-10, 2015. Disponível em: <http://seer.ufrgs.br/index.php/renote/article/view/61411>. Acesso em: 15 jun. 2017.

LEAL, Luiz Antonio Batista; D’ÁVILA, Cristina Maria. A ludicidade como princípio formativo. Interfaces Científicas Educação, Aracaju, v. 1, n. 2, p. 41-52, fev. 2013.

LÈVY, Pierre. A inteligência coletiva - para uma antropologia do ciberespaço. São Paulo: Cortez, 1998.

MANUAL de Orientação. Saúde de crianças e adolescentes na era digital. Departamento de Adolescência. Sociedade Brasileira de Pediatria. 01/10/2016. Disponível em: < http://www.sbp.com. $\mathrm{br} /$ fileadmin/user_upload/2016/11/19166d-MOrient-SaudeCrian-e-Adolesc.pdf>. Acesso em: 1 abr. 2017.

McGONIGAL, Jane. A realidade em jogo - por que os games nos tornam melhores e como eles podem mudar o mundo. Rio de Janeiro: Best Seller, 2012.

NETO, Antônio Oliveira; VERSUTI, Andrea; VAZ, Wesley, F. Perspectivas para o uso do WhatsApp Messenger no estímulo à aprendizagem dos sujeitos. In: COUTO, Edvaldo; PORTO, Cristiane; SANTOS, Edméa (Org.). App-learning - experiências de pesquisa e formaçáo. Salvador: EDUFBA, 2016. p. 227-244.

SANTOS, Vera Lúcia Pontes; PEREIRA, Jasete Maria Santos; MERCADO, Luís Paulo Leopoldo. WhatsApp: um viés online como estratégia didática na formação profissional de docentes. 
ETD: Educação Temática Digital, Campinas, SP, v.18, n.1, p.104121, 2016. Disponível em: <https://periodicos.sbu.unicamp.br/ojs/ index.php/etd/article/view/8637398>. Acesso em: 15 jun. 2017.

SIMPLES. Seguro. Troque mensagens com confiança. WhatsApp. 2017. Disponível em: <https://www. WhatsApp.com/?l=pt_br>. Acesso em: 1 abr. 2017. 


\title{
CONVERSAS UBÍQUAS \\ VIA WHATSAPP: \\ AMBIÊNCIAS FORMATIVAS MULTIRREFERENCIAIS
}

\author{
Rosemary dos Santos - UERJ \\ Felipe da Silva Ponte Carvalho - UERJ \\ Tânia Lúcia Maddalena - UERJ
}

\section{Introdução}

De acordo com o Balanço Huawei de Banda Larga (CORTEZ, 2013), pesquisa realizada em 2012, as conexóes móveis no Brasil chegaram aos 65,7 milhôes. Assim, com a comunicação cada vez mais móvel e menos confinada em lugares fixos, os fluxos de signos e de linguagens se aceleram, afetando nossos processos cognitivos, afetivos e nosso modo de viver (SANTAELLA, 2007).

Um estudo publicado em janeiro de 2015 pelo eMarketer (REDAÇÃO, 2015), posiciona o Brasil como o país com o maior número de usuários de smartphones na América Latina. São, ao todo, cerca de 38,8 milhôes de usuários, com projeção de 71,9 milhôes nos próximos três anos. O Brasil ocupa ainda, segundo este mesmo estudo, a sexta posição em um ranking com 25 mercados ao redor do mundo, como China, Estados Unidos, Japão, Índia e Rússia. Em outra pesquisa, publicada pela ETC (REDAÇÁO, 2014), em maio de 2014, no Brasil 40\% dos usuários se conectam por meio da Internet móvel, utilizando-a para diferentes fins: pesquisas, usos de redes sociais, games, compras on-line e usos do 
WhatsApp, que segundo pesquisa no Estadão (TOZETTO, 2016) em 2016, superou 1 bilhão de usuários em todo o mundo.

O aplicativo WhatsApp foi criado em 2009 por Jan Koun (EFE, 2014) e o site oficial ${ }^{1}$ o descreve como um aplicativo de mensagens multiplataforma que permite trocar mensagens pelo celular.

Para utilizar o aplicativo, o usuário precisa realizar seu download em um Smartphone, disponível para sistemas operacionais como Android (Google), iOS (Apple), BlackBerry OS, Symbian, Windows Phone e Nokia, e vincular sua conta a um número do telefone. Uma vez dentro do aplicativo, podem-se inserir informaçóes pessoais em um perfil, tais como nome, foto e status. As interaçôes no WhatsApp podem ser realizadas entre duas ou mais pessoas. Em casos de três ou mais participantes que realizam uma troca de mensagens contínua, a ferramenta permite a criação de um Grupo, que pode ser identificado por um nome e uma imagem (ambos editados pelo administrador deste grupo). Para o envio de uma mensagem simultânea para diferentes contatos, o sistema disponibiliza a opção Lista de Transmissão, geralmente utilizada para o envio de mensagens pontuais.

Figura 1 - Tela do WhatsApp

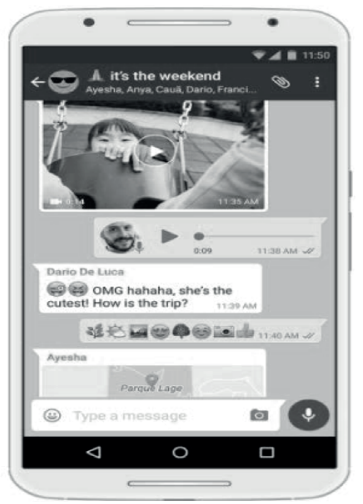

Fonte: https://www.whatsapp.com/ (2015).

1 Disponível em: <https://www.whatsapp.com/>. Acesso em: nov. 2015. 
Na opção Conversas, o usuário tem acesso ao registro de todas as interações com sinalizaçóes de quem enviou a mensagem, quando (horário ou dia), além de um pequeno excerto da última mensagem enviada. Ao acessar uma das conversas (seja com uma pessoa específica ou com um grupo), o usuário pode interagir com seus contatos, utilizando diferentes recursos do sistema, como textos, fotos, imagens, emoticons e vídeos armazenados na memória do Smartphone ou produzidos de forma síncrona à conversação.

Os usos dos dispositivos móveis pelos praticantes ${ }^{2}$ culturais têm surgido como uma busca de alternativas para a produção de outros conhecimentos e de outras práticas nas diversas redes educativas. E como pensarmos essas práticas a não ser pelas narrativas desses praticantes? É preciso ouvir o que eles têm a dizer nestes tantos espaçostempos ${ }^{3}$ dos quais fazem parte.

Para Santos (2011), a mobilidade é a capacidade de tratar a informação na dinâmica do movimento humano, na cidade e no ciberespaço, simultaneamente, por meio de interfaces que protagonizam essa dinâmica, por meio dos dispositivos móveis que podem mapear, acessar, manipular, criar, distribuir e compartilhar informaçóes e conhecimentos em qualquer tempo.

Ao trazer as conversas do WhatsApp como dispositivos de pesquisa, conforme discutiremos a seguir, percebemos que há pos-

2 Este termo é utilizado por Certeau (2009) para aqueles que vivem e envolvem-se dialogicamente com as práticas do cotidiano. Iremos utilizá-lo neste trabalho por concordarmos com o termo utilizado pelo autor: "o enfoque da cultura começa quando o homem ordinário se torna o narrador, quando define o lugar (comum) do discurso e o espaço (anônimo) de seu desenvolvimento". (CERTEAU, 2009, p. 63).

3 Adotamos o uso dos termos espaçostempos, fazeressaberesfazeres, dentrofora, entre outros, escritos de forma diferenciada, pois nos inspiramos no referencial teórico de Alves (2008) sobre as pesquisas nos/dos/com os cotidianos. Para a autora: "A junção de termos e a sua inversão, em alguns casos, quanto ao modo como são 'normalmente’ enunciados, nos pareceu, há algum tempo, a forma de mostrar os limites para as pesquisas nos/dos/com os cotidianos, do modo dicotomizado criado pela ciência moderna para analisar a sociedade" (ALVES, 2008, p. 11). 
sibilidade de maior interação entre subjetividades próprias dos praticantes pesquisados. É isso o que nos interessa como possibilidade de olhar as práticas que acontecem cotidianamente, uma aproximação, uma espécie de mergulho que nos permitem perceber os deslocamentos desses espaçostempos em que as pessoas têm dinamizado a produção de enunciados sobre lugares e acontecimentos, expressando diferentes perspectivas sobre o mundo.

\section{A Ciberpesquisa-formação multirreferencial e seus dispositivos}

Este estudo desenvolveu-se com os cotidianos do(a)s cursistas e um docente-pesquisador da disciplina Informática na Educação, do curso de licenciatura em Pedagogia, pela UERJ/CEDERJ/UAB, mediado pela plataforma Moodle, durante o semestre de 2014/02. A disciplina foi ofertada em doze polos localizados em Municípios do Estado do Rio de Janeiro.

Para essa pesquisa, optamos em nosso fazer ciência pela "epistemologia da multirreferencialidade" (ARDOINO, 1998), que é voltada para compreensão dos fenômenos humanos sob múltiplos pontos de vista e que não se reduzem uns aos outros. Esse fazer ciência nos ajuda na compreensão das práticas e relaçôes que são estabelecidas no cotidiano de pesquisa.

Ao optar por essa epistemologia e pelo método da ciberpesquisa-formação (SANTOS, 2005), reafirmamos que esta é uma opção política e faz contraponto aos pressupostos teóricos positivistas, tão sedimentados no campo educacional. Segundo Ardoino (1998), o surgimento da multirreferencialidade está ligado ao reconhecimento da complexidade e da heterogeneidade inerentes às práticas educativas, sempre na perspectiva de uma pluralidade de olhares e linguagens, reconhecidas como necessárias à compreensão do fenômeno complexo que é a Educação. 
Martins (1998) afirma que o conhecimento construído a partir da multirreferencialidade é um conhecimento inacabado e da falta. Ele é efetuado com uma "atividade artesanal", como uma bricolagem. E o pesquisador deve ter uma postura aberta. Martins (1998, p. 28) ratifica ainda: "esta perspectiva traz em si mesma (como implicaçáo) uma visão de mundo propriamente cultural e requer uma compreensão hermenêutica da situação em que os sujeitos aí implicados interagem intersubjetivamente".

A multirreferencialidade é uma epistemologia das correntes das práticas, proporciona a compreensão de múltiplas maneiras de pensar e de habitar o mundo, nas quais redes de significados são tecidas e ampliam-se os repertórios culturais por meio de dispositivos e de "espaços multirreferenciais de aprendizagem" (BURNHAM, 2012).

A noção de "dispositivo" utilizada por nós é definida por Ardoino (2003, p. 80) como "a organização de meios materiais el ou intelectuais, fazendo parte de uma estratégia de conhecimento de um objeto". Para o autor, o dispositivo de pesquisa está sempre implícito ou explícito em todo método de investigação e que todo trabalho de pesquisa deve deixar explicitado o dispositivo que é acionado pelo pesquisador ou pelos pesquisados, pois embora sustentemos a ideia de que os dispositivos sáo acionados no campo pelo pesquisador em seu processo da pesquisa, acreditamos também que estes podem emergir durante o devir da pesquisa, seguindo os rastros, imersos no campo, no diálogo com os praticantes culturais pela característica e dinâmica do próprio campo.

Nesta ciberpesquisa-formação, nos inspiramos na ideia de que o dispositivo de ciberpesquisa-formação é um instrumento capaz de captar singularidades, pluralidades, objetividades e subjetividades de uma realidade em uma pesquisa. Para Macedo (2009), a pesquisa é, acima de tudo, uma aventura pensada, implicada com conhecimento historicamente acumulado e também um imaginário em criação. Ela é produzida numa comunidade de argumentos 
e existe para provocar alterações, turbulências, inacabamentos, relações instáveis, consensos não resignados.

Uma das autorias mais importantes da ciberpesquisa-formação é o reconhecimento das interfaces interativas e das redes sociais como dispositivos materiais e/ ou intelectuais para o pesquisador da contemporaneidade. Em sua tese de doutorado (SANTOS, 2015), pesquisou os grupos de pesquisa on-line onde professores-formadores sistematizaram ambiências formativas, articulando o espaço da universidade e das redes sociais, criando redes de docência e aprendizagem. Como dispositivos de pesquisa, a autora lançou mão das conversas e da participação nos grupos de pesquisa com a intenção de vivenciar práticas interativas próprias da cibercultura. Inspirados em sua pesquisa, iremos problematizar algumas ambiências disparadoras de conversas, desta vez utilizando o aplicativo WhatsApp na pesquisa de mestrado Atos de currículo na educação online (CARVALHO, 2015).

\section{Ambiências disparadores de conversas: bricolando dispositivos}

Compreender o sentido de "espaços de aprendizagem" é um passo necessário para entender os espaços multirreferenciais de aprendizagem (SANTOS, 2005) tomados por nós como fundamental para apresentar nosso campo de pesquisa. Os autores que trabalham com a multirreferencialidade partem do seguinte pressuposto: o ser humano é multirreferencial em sua essência, isto é, o eu é composto da relação com o outro. Esse fundamento sustenta o arcabouço teórico dos espaços multirreferenciais de aprendizagem e da bricolagem de dispositivos.

No campo da pesquisa educacional, Kincheloe (2006) seguiu um raciocínio semelhante ao conceituar a bricolagem como um modo de investigação que busca incorporar diferentes pontos de 
vista a respeito de um mesmo fenômeno. Em trabalho posterior, Kincheloe (2007) ampliou essa definição ao dizer que bricolagem é uma forma de fazer ciência que analisa e interpreta os fenômenos a partir de diversos olhares existentes na sociedade atual, sem que as relaçôes de poder presentes no cotidiano sejam desconsideradas. Certeau (2009) e Kincheloe (2007) argumentam que a bricolagem rejeita as diretrizes e roteiros preexistentes, para criar processos de investigação no devir da pesquisa.

$\mathrm{Na}$ "Aula 3 - Escrita colaborativa”, exposta na Figura 2, organizada na plataforma Moodle, foram acionados três fóruns: (a) "Achados e perdidos" - para ajudar os cursistas a sanarem seus dilemas e dúvidas em relação à atividade; (b) "Navegar é preciso" para formação de grupo, com até cinco participantes; (c) "Nossas wikis" - para o compartilhamento dos textos (wikis) criados coletivamente pelos cursistas.

Os dispositivos acionados para aula 3 foram usados com a intencionalidade de: (a) possibilitar maior imersão dos praticantes nos ambientes online, seja em trabalhos individuais ou em grupos; (b) explorar a autoria coletiva por meio de outros ambientes virtuais de aprendizagem; e (c) intercambiar trocas de conhecimento e experiências entre polos distintos por meio de conversas.

Figura 2 - Aula 3 - Escrita colaborativa em atos de currículo

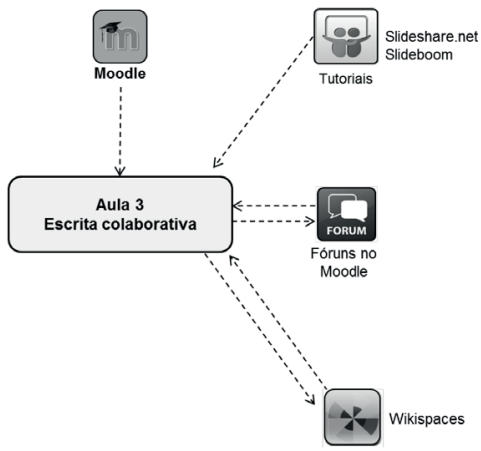

Fonte: Carvalho (2015). 
A escolha pelos fóruns decorre da necessidade de criar espaços para promover conversas elaboradas e densas, para que o(a) $s$ praticantes pesquisado(a)s exponham suas reflexões, tragam seus dilemas, inquietações, práticas e experiências no partilhar coletivo, discutindo uns com os outros, confrontando suas certezas e (re) construindo outras em vista do novo que se apresenta, que afeta e altera. Galvão, Fuks e Pimentel (2014) tencionam essa discussão ao dizer que o fórum é um meio de conversação assíncrono para a discussáo entre muitos interlocutores que trocam mensagens de texto elaboradas, organizadas em tópicos, é usado para a conversação em grupo e requer que os interlocutores mobilizem discussão com mais profundidade.

A Wikispaces é uma plataforma educacional voltada à prática educativa, fundada em 2005, na qual a docência pode se inspirar, planejar e gerenciar as atividades com os alunos. Possibilita a criação de ambientes para trabalhos em grupos, com no máximo de cinco integrantes (um administrador, que é responsável por convidar os demais participantes para entrar no grupo, e mais quatro participantes). Para ajudar os estudantes na realização da atividade proposta para "Aula 3 - Escrita colaborativa!", criamos tutoriais sobre Wiki e em relação à plataforma Wikispaces ${ }^{4}$, que estão hospedados nas interfaces do Slideshare e Slidebom $^{6}$.

No decorrer dessa aula e para nossa surpresa, o(a)s cursistas começaram a disponibilizar seus números de telefones no "Fórum Navegar é preciso", principalmente para formarem grupos pelo aplicativo para celular WhatsApp, para discutir a atividade proposta, ou seja, acionaram o dispositivo de pesquisa que depois foram usados pelo pesquisador. Com o objetivo de compreender esse movimento dos (as) cursistas, compartilhamos nossos números de

4 Disponível em: https://www.wikispaces.com/content/classroom. Acesso em: 21 nov. 2015.

5 Disponível em: http://pt.slideshare.net/?ss. Acesso em 14.11.2015.

6 Disponível em: http://pt.slideshare.net/?ss. Acesso em 14.11.2015. 
telefones também. Após nos adicionarem aos grupos criados, pedimos licença e perguntamos se poderíamos usar as conversas tecidas pelo aplicativo na pesquisa acadêmica. Todos os participantes dos grupos autorizaram o uso de suas falas.

$\mathrm{O}$ acionamento desse dispositivo nos remete ao pensamento Macedo (2009) quando salienta que os dispositivos de pesquisa não podem significar algo eterno, fixado de uma vez por todas, mas que devem ser construídos dentro de um dinamismo, movimento, algo se fazendo. "Uma espécie de método aberto, que nos coloca em ato" (MACEDO, 2009 p. 110).

\section{Conversas como dispositivos de pesquisa}

Conversa, roda de conversa, grupo focal, entrevista estruturada ou semiestruturada, questionário aberto, semiaberto ou fechado, aulas são alguns dos "recursos" (BATISTA; BERNARDES; MENEGON, 2014) ou "dispositivos" (ARDOINO, 2003; MACEDO, 2010) usados em métodos de pesquisa para disparar, promover, obter e cocriar narrativas e imagens no cotidiano da pesquisa. Tendo em vista esses diversos dispositivos ou recursos, optamos por usar a conversa na pesquisa acadêmica. Assim como Alves (2003), preferimos o termo "conversa" ao termo "entrevista", pois o que fazemos em nossos encontros é conversar, tanto por decisão metodológica, como porque é isso que professores gostam de fazer quando se encontram.

Batista, Bernardes e Menegon (2014) criticam modelos hegemônicos de fazer ciência que não legitimam a "conversa cotidiana” na pesquisa científica. Opondo-se a esses modelos, os autores argumentam que a conversa cotidiana não está pautada na objetividade que esses modelos exigem e que "não há sentido abandonar a conversa no cotidiano como método de pesquisa, até por que as conversas são protagonistas relevantes e ativas na produção de conhecimento" (idem, p. 97). 
Os autores acreditam que a maneira de fazer ciência cartesiana enrijece a conversa. $\mathrm{O}$ que por outro lado amplia o distanciamento entre as conversas e a produção do conhecimento. Fica evidente essa crítica pelos autores quando afirmam que "a conversa, normalmente, é aprisionada e cristalizada sob a égide de um script materializado por nomes diversos: entrevista, questionário, grupo focal, testes, dinâmicas e correlatos" (p. 100). Concordamos com este posicionamento, porém não negamos o potencial de outros dispositivos ou recursos, dado que cada pesquisa tem suas próprias demandas e especificidades.

Acreditamos que trabalhar com a conversa como dispositivo de pesquisa é estar aberto a fala do e com o outro. É ter uma escuta sensível (BARBIER, 2002) e apurada do que se conversa, quem são os falantes e em qual cenário a conversa se situa. Conversar é um jogo de idas e de vindas entre negociaçóes e buscas por significados e sentidos. Sendo, portanto, um jogo de tensôes e de problematizaçôes, do qual emergem dados genuínos, complexos e ricos para a pesquisa acadêmica.

Nesta Seção, discutimos os usos de conversas na pesquisa acadêmica. As referências que trouxemos para a discussão nos possibilitaram uma compreensão plural da conversa enquanto dispositivo de pesquisa e de formação. Partindo desses pressupostos e ampliando a discussão, optamos por trazer para esta pesquisa as conversas que aconteceram pelo aplicativo WhatsApp, no contexto da "Aula 3 - Escrita colaborativa".

\section{Cartografando a noção emergente: "conversas ubíquas"}

Para cartografar e compreender as conversas das cursistas e docente-pesquisador que aconteceram pelo aplicativo WhatsApp, lançamos mão de dois movimentos: a) Apreensão fina e interpretação do cotidiano pesquisado e b) A tessitura teórica-metodológi- 
ca-epistemológica. Esses dois movimentos nos ajudaram a chegar à noção de "conversas ubíquas", que denominamos como conversas que acontecem em diversos espaçostempos mediadas por dispositivos móveis conectados em rede.

\section{Apreensão fina e interpretação do cotidiano pesquisado}

Objetiva capturar narrativas e imagens que mostrem evidências, indícios, repetiçóes, contradiçóes, significados e sentidos que podem contribuir para a composição da noção emergente. Requer, com isso, atenção, ética, implicação do pesquisador e mergulho no cotidiano pesquisado.

Para fazer a apreensão fina e interpretação do cotidiano, partimos do "contexto de pesquisa" e da "compreensão da conversa".

Contexto de pesquisa - conversas das cursistas e docentepesquisador pelo aplicativo WhatsApp.

Compreensáo da conversa - buscamos revelar as narrativas significativas que emergem das conversas entre as cursistas e o docente-pesquisador. Nesse processo, partimos do pressuposto que o pesquisador deve levar em consideração o cotidiano de cada um do(a)s participantes da pesquisa e suas histórias e experiências de vida. Por meio das conversas, é possível compreender como as cursistas e o docente-pesquisador produzem sentidos, negociam suas relaçóes diárias e se posicionam a partir do mundo que habitam. A compreensão da conversa se desdobra em:

Organização da atividade proposta - É possível observar como as cursistas se organizaram para realizar a atividade proposta da “Aula 3 - Escrita colaborativa!", conforme exposto a seguir:

Rita: Meninas, criei o perfil na wikispace, só o cadastro: cibernéticas - senha xxxxx

Rita: Coloquei com o nome da wiki: Grupo Cibernéticas

Rita: pode ser? 
Rita: e vou procurar tutoriais para a gente aprender a usar, caso alguém já saiba, nos ensine tb!!!! é um ambiente com bastante recursos

Rita: vou pesquisar textos e imagens tb, sobre os temas das aulas

Rita: qq coisa to por aqui

Rita: bjks

Rita: já adicionei vcs, depois da uma olhada no e-mail

Rita: tutorial: http://wikistorias.wikispaces.com/tutorial

Rita: minha atividade é a noite, pois de dia estou cuidando de uma filhota de 6 meses e um filhão de 8 anos Alessandra: Legal o nome... eu também costumo estudar na madrugada, também tenho um filhote de 3 aninhos q não pode me ver no computador. Alessandra: Vou dar uma olhada no email. ...

Alessandra: Bjos! Rita : ok

Rita : bjks

Felipe Carvalho: Olá pessoal Felipe Carvalho: Qualquer ajuda eu estarei por aqui

Viviane: Obrigada!

Atravessamentos e desdobramentos de outras conversas - São as conversas que rompem com a temática em discussão e trazem outras temáticas, situaçóes, experiências e práticas cotidianas:

Rita: minha atividade é a noite, pois de dia estou cuidando de uma filhota de 6 meses e um filhão de 8 anos

Alessandra: eu também costumo estudar na madrugada, também tenho um filhote de 3 aninhos q náo pode me ver no computador. ...

As partilhas de uso - são os métodos que as cursistas usaram para realizar a atividade prática da escrita colaborativa pela plataforma Wikispaces: 
Rita: e vou procurar tutoriais para a gente aprender a usar, caso alguém já saiba, nos ensine tb!!!! é um ambiente com bastante recursos. vou pesquisar textos e imagens tb, sobre os temas das aulas. qq coisa to por aqui. bjks (...)

Viviane: Visitei o wikispace, é tudo inglês. Ai! Nao entendo! E agora?

Alessandra: Bem, é possível usar um tradutor on line

Alessandra: Google por exemplo

Viviane: Sim. Estou fazendo isso

\section{A tessitura teórica-metodológica-epistemológica nas conversas ubíquas}

Para compreender como as conversas entre as cursistas e o docente-pesquisador pelo WhatsApp tencionam um diálogo ampliado em nosso pensar-fazer a ciência, optamos por dialogar com referenciais teóricos, metodológicos e epistemológicos que nos possibilitaram maior compreensão e dimensão do cotidiano pesquisado, como também as lógicas que por ali são operacionalizadas, as relaçóes e os sentidos que são tecidos.

A compreensão da conversa se desdobra em:

O aprender contextualizado, social, politica e culturalmente - É muito mais do que um trabalho cognitivo e intelectual de explicação, aprendemos com nossas experiências afetivas, pois o afetivo aprende, o social aprende, o político aprende, o cultural aprende, e, ao aprendermos, lutamos por significar, significando as nossas práticas cotidianas.

Felipe Carvalho: Vocês já escolheram o tema?

Alessandra: Pessoal, que tal um tema sobre inclusão digital.... poderíamos abordar neste tema todos os assuntos apresentados na plataforma.

Alessandra: Estou pesquisando mais... daqui a pouco volto... 
Felipe Carvalho: Eu tenho a introdução de um livro ótimo sobre inclusão digital

Felipe Carvalho: Vou mandar para vcs olharem

Viviane: Adorei o tema

Alessandra: Legal!!!! Só preciso da confirmação das meninas

Viviane: Ainda estou no trabalho

Alessandra: Showwww

Viviane: Em casa eu vou pesquisar mais e retorno

Alessandra: Rita, o que vc acha?

Alessandra: E Ana também?

Felipe Carvalho: https://repositorio.ufba.br/ri/handle/ri/4859

Felipe Carvalho: Link do livro, a introdução já ajudará muito

Alessandra: $\mathrm{Ok}$

Alessandra: Obrigada!

Rita : é um ótimo tema e a partir daí podemos entrar em outros

Rita : vou dar uma olhada no livro

Rita : obrigado Felipe!

Viviane: Tbm vou olhar

Narrativas do fazerpensar em formação - Concordamos com a perspectiva de Josso (2004, p. 34) de que formação é um conceito em construção, porque consiste na narração de "conhecimento e de aprendizagem a partir das experiências formadoras". Ele nasce da capacidade e do investimento do praticante cultural em narrar sobre as coisas que faz, estabelecendo sentido ao que foi e é vivido por meio dos seus significados particulares e coletivos.

Viviane: Hoje madruguei para ver o nosso trabalho. Só assim q consigo fazer alguma coisa

Viviane: Visitei o wikispace, é tudo inglês 
Viviane: Ai! Nao entendo!

Viviane: E agora?

Alessandra: Eu tô trabalhando hj... graças a Deus tô podendo acessar daqui...

Viviane: Hum

Viviane: Entendeu alguma coisa?

Alessandra: Bem, é possível usar um tradutor on line

Alessandra: Google por exemplo

Felipe: Sim. To saindo daqui da UERJ

Felipe: $\mathrm{E}$ já irei ver

Rita: ok... cuidado aí!

Felipe: Aqui está maior tiroteio , Mangueira com tiros

Rita: hjh ta complicado em vários lugares

Rita: e aí já é ruim sem tiroteio

Felipe: Uhum. Eu entrei no site pelo celular

Felipe: Mas não consigo visualizar

Felipe: Quando chegar em casa vejo e te dou um retorno

Rita: ok... vou ficar por aqui até umas 2

Felipe: Assim q chegar olho. Pois irei olhar de outros grupos

Rita: ok

Felipe: Só falta agora criar a página onde o texto será feito ou colocado

Rita: já sei o que eu fiz.... Eu criei um projeto com o nome do grupo, depois formei uma equipe e depois a pagina

Rita: https://grupociberneticas.wikispaces.com/-/A\%20era\%20 da\%20inclus\%C3\%A3o\%20digital/Cibern\%C3\%A9ticas $\% 20$ $\mathrm{AD} 2 /$ Inclus \%C3\%A3o+Digital

Rita: vou simplificar esse caminho

Felipe: Isso dá para saber no ambiente

Felipe: Quem faz e quem não faz 
Felipe: Mas por aqui acompanho vcs

Felipe: Fica tranquila

Rita: é pq eu posto como a criadora da wikispace, n vai aparecer meu nome...

Rita: mas de qq forma, eu vou postar na pagina inicial da wikispace

Rita: pq eu coloquei dentro de um projeto

Rita: https:/grupociberneticas.wikispaces.com/Inclus\%C3\%A3o + Digital

Rita: agora sim

Felipe: Agora foi

Felipe: Vou ler aqui e depois te dou um retorno

Rita: ok

Felipe: Para revisar o texto: trocar informatização por digital, tira o mais da terceira frase; o que é o ciberespaço? Sugiro digital em rede ou então faça uma pequena explicação sobre a questão que trouxe. No segundo parágrafo, tira as vírgulas logo no início.

Felipe: Está ok

Buscar compreender o processo formativo que atravessa a docência é criar um exercício interpretativo de autoria, produçáo discursiva e teórica de interpretar interpretando-se, recriando, inclusive, os modos de pensar e de fazer novas educaçóes (PRETTO, 2011).

As conversas ubíquas entre usuários e a troca de vídeos, fotos, textos e músicas podem ser feitas de qualquer lugar para qualquer lugar em tempo real, uma transformação tecida no seio da cibercultura, que é capaz de dinamizar intensamente as redes, como nos aponta Santos (2014, p. 33):

Muito mais que circular pelos espaços urbanos portando a mídia e a linguagem, circulamos agora 
com a convergência de diversas mídias e linguagens, que se configuram e reconfiguram para além da dicotomia upload ou download. A tecnologia da mobilidade ubíqua não se limita apenas ao computador que se libertou do desktop e das conexôes fixas para acesso ao ciberespaço. Caracteriza-se, sobretudo, pela conexão constante e ubíqua com o ciberespaço, com os espaços urbanos e interaçóes sociais diversas com e nesses espaços.

Acreditamos que a formação na cibercultura consiste, pois, em um processo que se dá em rede e na rede, onde a interação entre os outros contextos e o modo como nessas interaçóes incorporamos e significamos os conhecimentos e valores nos permitem atuarmos em nossas práticas.

\section{Consideraçóes finais}

Começamos este artigo problematizando os usos dos dispositivos móveis pelos praticantes culturais e como estes têm surgido como uma busca de alternativas para a produção de outros conhecimentos e de outras práticas nas diversas redes educativas.

$\mathrm{O}$ que nos interessou foi a possibilidade de olhar as práticas que acontecem cotidianamente, uma aproximação, uma espécie de mergulho que nos permitiram perceber os deslocamentos desses espaçostempos em que as pessoas têm dinamizado a produção de enunciados sobre lugares e acontecimentos, expressando diferentes perspectivas sobre o mundo. Nas conversas pelo WhatsApp fatos foram retratados por diferentes perspectivas, experimentados por diversas pessoas que, em interação com os seus dispositivos móveis, vivenciam dinâmicas produziram outros conhecimentos.

Refletimos em relação aos usos das conversas do aplicativo WhastApp na pesquisa acadêmica e como estes usos possibilitaram algumas contribuiçóes para a formação. Por fim, gostaríamos de 
trazer uma última problematização: defendemos uma concepção de Educação, na qual acreditamos que o conhecimento é tecido em redes de significados e relaçôes. Nessa tessitura o conhecimento emerge no encontro, na conexão, na rede, nas conversas e "no entre". Nessa perspectiva, interagimos não apenas uns com os outros, mas também com as coisas, com as imagens, com os textos, com os sons, com as memórias, com os dispositivos e tudo o mais que está no mundo. Assim, é claro que as novas tecnologias digitais, não apenas potencializam essas redes, mas é parte integrante delas. São constitutivas dos conhecimentos tecidos.

Assim, chegamos à noção de conversas ubíquas, que são as conversas que acontecem em diversos espaçostempos mediadas por dispositivos móveis conectados em rede. Isso implica ao mesmo tempo compreender os dilemas docentes, o próprio papel do professor, suas relaçóes com os alunos, com as tecnologias digitais, estruturando a relação cidade-universidade. Como educar em nosso tempo com os usos dessas tecnologias será um dos nossos desafios. Precisaremos repensar os currículos em tempo de cibercultura e suas potencialidades comunicacionais e educativas.

\section{Referências}

\section{ALVES, N. Cultura e cotidiano escolar. Revista Brasileira de}

Educação, Campinas: Autores Associados, n. 23, maio/ago. 2003.

ALVES, N. Sobre o movimento das pesquisas nos/dos/com os cotidianos. In: OLIVEIRA, Inês Barbosa; ALVES, Nilda (Org.). Pesquisa no/do cotidiano das escolas: sobre redes de saberes. Petrópolis: DP\&A, 2008.

ARDOINO, J. Abordagem multirreferencial (plural) das situações educativas e formativas. In: BARBOSA, J.G. (Coord.). 
Multirreferencialidade nas ciências e na educaçáo. São Carlos: EdUFSCar, 1998. p. 58-78.

ARDOINO, J. Para uma pedagogia socialista. Brasília: Plano, 2003.

BARBIER, R. A pesquisa-ação. Brasília: Plano, 2002.

BATISTA, Cristina Santos; BERNARDES, Jefferson;

MENEGON, Vera Sônia. Conversas no cotidiano: um dedo de prosa na pesquisa. In: SPINK, Mary Jane Paris et al. (Org.). A produçáo da informaçáo na pesquisa social: compartilhando ferramentas. Rio de Janeiro: Centro Edelstein de Pesquisas Sociais, 2014. p. 97-122.

BURNHAM, Teresinha Fróes. Espaços multirreferenciais de aprendizagem: lócus de resistência à segregação cognitiva? In: BURNHAM, Teresinha Fróes e coletivo de autores. Análise cognitiva e espaços multirreferenciais de aprendizagem: currículo, educação à distância e gestão/difusão do conhecimento. Salvador: EDUFBA, 2012.

CALVÃO, Leandro Dantas; PIMENTEL, Mariano; FUKS, Hugo. Do email ao Facebook: uma perspectiva evolucionista sobre os meios de conversação da internet. Rio de Janeiro: Ed. UNIRIO, 2014.

CARVAlHO, Felipe da Silva Ponte de Carvalho. Atos de currículo na educaçáo online. 2015. 202f. Dissertação (Mestrado em Educação) - Faculdade de Educação, Universidade do Estado do Rio de Janeiro, Rio de Janeiro, 2015.

CERTEAU, M. de. A invenção do cotidiano 1: artes de fazer. Petrópolis: Vozes, 2009. 
CORTEZ, Bruna. Internet móvel cresceu 59\% em 2012.

Observatório da Imprensa. 16/04/2013. Disponível em: < http:// observatoriodaimprensa.com.br/interesse-publico/_ed742_ internet_movel_cresceu_59_em_2012/>.Acesso em: nov. 2015.

EFE. Criador do WhatsApp, Jan Koum foi de imigrante pobre a multimilionário. Folha Digital, Washington, 23/02/2014. Disponível em: < http://www1.folha.uol.com.br/ tec/2014/02/1415716-criador-do-whatsapp-jan-koum-foi-deimigrante-pobre-a-multimilionario.shtml >. Acesso em: nov. 2015.

JOSSO, M.C. Experiências de vida e formação. São Paulo: Cortez, 2004.

MACEDO, R.S. Outras luzes: um rigor intercrítico para uma etnopesquisa política. In: MACEDO, R.S.; GALEFFI, D.; PIMENTEL, A. Um rigor outro: sobre a questão da qualidade na pesquisa qualitativa. Salvador: Edufba, 2009.

MARTINS, João Batista. Multirreferencialidade e Educação. In: BARBOSA, Joaquim Gonçalves (Org.). Reflexóes em torno da abordagem multirreferencial. São Carlos: Edufscar, 1998.

KINCHELOE, J. L.; McLAREN, P. Repensando a teoria crítica e a pesquisa qualitativa. In: DENZIN, N.K.; LINCOLN, I. S. O planejamento da pesquisa qualitativa: teorias e abordagens. Tradução de Sandra Regina Netz. Porto Alegre: Artmed, 2006.

KINCHELOE, J. L. Redefinindo e interpretando o objeto de estudo. In: KINCHELOE, J.L.; BERRY, K.S. Pesquisa em educaçáo: conceituando a bricolagem. Tradução de Roberto Cataldo Costa. Porto Alegre: Artmed, 2007. 
PRETTO, N. O desafio de educar na era digital. Revista Portuguesa de Educação, v. 4, n. 1, 2011.

REDAÇÃO. Brasil lidera uso de smartphone na América Latina. Computer World. 07/01/2015. Disponível em: < http:// computerworld.com.br/telecom/2015/01/07/brasil-lidera-uso-desmartphone-na-america-latina/>. Acesso em: nov. 2015.

REDAÇÃO. No Brasil, 40\% dos usuários se conectam por meio da Internet móvel: $\mathrm{O}$ uso da Internet mobile está crescendo amplamente na América Latina IDGNOW. 12 de maio de 2014. Disponível em: <http://idgnow.com.br/mobilidade/2014/05/12/ no-brasil-40-dos-usuarios-se-conectam-por-meio-da-internetmovel/>. Acesso em: nov. 2015.

\section{SANTAELLA, L. Linguagens líquidas na era da mobilidade.}

São Paulo: Paulus, 2007.

SANTOS, E. Educação online: cibercultura e pesquisa-formação na prática docente. Salvador, 2005. 351f. Tese (Doutorado em Educação) - FACED-UFBA, Universidade Federal da Bahia, Salvador, Bahia, 2005.

SANTOS, E. Cibercultura: o que muda na educação. Entrevista ao programa Salto para o Futuro. TV Brasil. Disponível em: $<$ http://tvbrasil.org.br/saltoparaofuturo/entrevista.asp?.cod_ Entrevista=119>. Acesso em: 6 jun. 2014.

SANTOS, E. Pesquisa-formaçáo na cibercultura. Santo Tirso, PT: Whitebooks, 2014. p.33-34.

SANTOS, R. A tessitura do conhecimento via mídias digitais e redes sociais: itinerâncias de uma pesquisa-formação 
multirreferencial. 2011. 232 f. Dissertação (Mestrado em Educação) - Faculdade de Educação, Universidade do Estado do Rio de Janeiro, Rio de Janeiro, 2011.

\section{SANTOS, R. Formaçáo de Formadores e Educação Superior na} cibercultura: itinerâncias de Grupos de Pesquisa no Facebook. 2015. 183f. Tese (Doutorado em Educação) - Faculdade de Educação, Universidade do Estado do Rio de Janeiro, Rio de Janeiro, 2015.

TOZETTO, Claudia. WhatsApp supera 1 bilhão de usuários em todo o mundo. Estadâo. 01/02/2016. Disponível em: < http://link. estadao.com.br/noticias/empresas, whatsapp-supera-1-bilhao-deusuarios-em-todo-o-mundo,10000028532>. Acesso em: nov. 2015. 


\section{TEMA 3 \\ WHATSAPP, AUTORIA E PRÁTICA DOCENTE}




\section{ENTRE PROCESSOS \\ FORMATIVOS E INTERATIVOS: \\ O WHATSAPP COMO ESPAÇO SIGNIFICATIVO NA ORIENTAÇÃO E FORMAÇÁO}

Carloney Alves de Oliveira - UFAL

\section{Introdução}

No momento de mudanças pedagógicas no contexto da sociedade em que vivemos, exigem-se dos profissionais da educaçáo o domínio e o compartilhamento de ideias a partir da sua prática pedagógica com as tecnologias móveis, já que tais tecnologias permitem configurar novas maneiras para seus usuários utilizarem e ampliarem suas possibilidades de expressão, a construção de significados, bem como atuarem para significar o mundo e com ele interagir.

Do ponto de vista educacional, as tecnologias móveis, e de modo particular, a utilização do WhatsApp, vêm conquistando seu espaço na busca de mudanças na prática pedagógica dos professores, para que possam trabalhar nas suas aulas, não de forma linear, mas ampliando a sua visão de mundo, objetivando proporcionar espaços para a construçáo do saber ao processo de aprendizagem dos nossos alunos, a fim de que estes possam construir conceitos e produzir significados nas suas aulas, buscando ressaltar os valores e atitudes de um profissional crítico-reflexivo. 
Para Santaella (2013, p. 291), o uso de dispositivos móveis na educação envolve

[...] processos de aprendizagem abertos que significam processos espontâneos, assistemáticos e mesmo caóticos, atualizados ao sabor das circunstâncias e de curiosidades contingentes. $\mathrm{O}$ advento dos dispositivos móveis ativou esses processos, pois graças a eles, o acesso à informação tornou-se livre e contínuo, a qualquer hora do dia e da noite, trazendo gratificação instantânea.

O desafio de fazer pesquisa em Educação e tecnologias móveis nos remete a reflexóes sobre as possibilidades e potencialidades que esse binário possui para produzir significados nos processos de ensino e de aprendizagem, dentro e fora da escola, para a reorganização do pensamento relativo às mudanças curriculares, buscando encarar desafios, numa construção coletiva de conhecimento científico.

As tecnologias móveis têm provocado reflexôes na educação por causa de sua capacidade de "ensinar". As possibilidades de implantação de novas técnicas de ensino são praticamente ilimitadas (MARINHO, 2015). No contexto educacional, a aprendizagem nesta perspectiva depende de açóes que caracterizam o 'fazer pedagógico': experimentar, interpretar, visualizar, induzir, conjecturar, abstrair, generalizar e, enfim, demonstrar. É o aluno agindo, diferentemente de seu papel passivo ante uma apresentação formal do conhecimento, baseada essencialmente na transmissão ordenada de 'fatos', geralmente na forma de definiçóes e propriedades.

A partir deste contexto trabalhamos com a utilização do WhatsApp nos processos de orientação e formação de dois bolsistas do Programa Institucional de Bolsas de Iniciação Científica (PIBIC)/UFAL do curso de Pedagogia da Universidade Federal de Alagoas (UFAL), pelas quais ocorreram variados tipos de interação entre estudantes e professor-orientador do projeto intitulado 
"Laboratório de educação matemática e a formação do pedagogo: concepçôes e comunidades de práticas”.

Como objetivos deste estudo, buscamos analisar as contribuiçôes e as potencialidades do WhatsApp nos processos de orientação e formação de bolsistas do Programa Institucional de Bolsas de Iniciação Científica (PIBIC)/UFAL; refletir sobre a formação do pedagogo em face do WhatsApp e propiciar interaçóes entre os sujeitos envolvidos por meio de estratégias didáticas.

A utilização do WhatsApp no ensino de Matemática pode ser utilizado na prática pedagógica do professor como atribuição de sentido ao processo educativo e à produção de significados nas suas aulas de Matemática, possibilitando acesso às informações de diferentes formas por meio de sons, imagens, textos e vídeos, permitindo ao aluno melhorias na aprendizagem e contribuindo para o seu aperfeiçoamento e construção de conceitos matemáticos. É possível perceber nesse recurso, nas múltiplas interfaces oferecidas aos seus usuários, a oportunidade de discutir e compartilhar elementos que favoreçam a interatividade e a aprendizagem.

Desse modo, faz-se necessário refletir acerca do WhatsApp para a formação dos professores e seu impacto no contexto educacional, a partir das necessidades e dos objetivos em função de sujeito e da proposta pedagógica de cada curso, pois é por meio desses ambientes que o processo de ensino e de aprendizagem e a formação do professor ocorrem, sendo possível motivar, formar, auxiliar no desenvolvimento cognitivo do sujeito, atingir perfis diferentes, melhorar a formação, fornecer feedback e incorporar interfaces que promovam a troca de informaçóes, reflexóes e pesquisas mediante uma comunicação síncrona e assíncrona.

\section{WhatsApp e a formaçáo do pedagogo}

A utilização do WhatsApp como recurso educacional possibilita aos alunos, resolver problemas, construir e buscar conhecimen- 
to, criando um ambiente desafiador e aberto ao questionamento, capaz de instigar a curiosidade e criatividade desses sujeitos.

Esse aplicativo pode ser utilizado como um catalisador de uma mudança no paradigma educacional, que promova a aprendizagem ao invés do ensino, que coloque o controle do processo de aprendizagem nas máos do aprendiz. Isso auxilia o professor a entender que a educação não é somente a transferência da informação, mas um processo de construção do conhecimento do aluno, como produto do seu próprio engajamento intelectual ou do aluno como um todo.

Segundo Behrens (2011, p. 3), os nativos digitais "enfrentam desafios a partir das problematizaçóes reais do mundo contemporâneo e demandam açóes conjuntas", assim como defendia Papert (1994, p. 21), afirmando que "as crianças podem aprender a usar computadores habilmente e essa aprendizagem pode mudar a maneira como elas conhecem outras coisas".

Do ponto de vista formativo, as tecnologias móveis podem proporcionar contextos de aprendizagem que favoreçam o pensamento reflexivo e de autoria, destacando novas dimensóes de interação em rede, indo além da linearidade com o hipertexto, pois a navegabilidade de um ambiente hipertextual corresponde à facilidade do usuário em encontrar a informação, disponível em forma de páginas ligadas por links, permitindo ao usuário a rápida localização da informação. Assim, quando o leitor escolhe seu percurso na rede, ele interfere na organização do espaço de sentido do texto, interliga redes escondidas sob os nós, ativando, deste modo, construçóes semânticas, ou as anula se não forem as de sua preferência.

De acordo com Valente (2014), com os aplicativos móveis na educação é possível permitir e oferecer aos seus usuários acesso à informação, conversação com os sujeitos envolvidos e a liberdade de navegabilidade em tempo e espaço, possibilitando, de forma integrada, o desenvolvimento de tarefas, veiculação de dados, ajustes às necessidades e aos objetivos de cada curso, na organização, 
reorganização e flexibilização curricular, a fim de atender às novas exigências para a construção do conhecimento sistematizado, que instiguem a investigação e a curiosidade do sujeito em formação.

As mudanças introduzidas pelas tecnologias digitais (TD) podem contribuir para o enriquecimento progressivo dos ambientes e contextos de aprendizagem, convidando o professor a ampliar e reformular suas práticas pedagógicas, para que os alunos possam escolher novos caminhos, visto que a produção do conhecimento está associada à ideia de construção conjunta.

As TD têm o computador conectado à internet como instrumento principal da integração e podem favorecer o processo de ensino e de aprendizagem, revelando possibilidades de criação dialógica propiciada pelas interaçóes de pensamentos, conceitos, imagens, mídias e ideias, nas quais o sujeito atua de forma consciente com os objetos do conhecimento, pois conforme Valente (2007, p. 38),

[...] o processo ensino-aprendizagem deve incorporar cada vez mais o uso das tecnologias digitais para que os alunos e os educadores possam manipular e aprender a ler, escrever e expressar-se usando essas novas modalidades e meios de comunicação, procurando atingir o nível de letramento.

Com as TD no contexto educacional, professores e alunos precisam ser muito flexíveis e criativos na valorização da construção coletiva, da criatividade, da aprendizagem por meio da imagem, do audiovisual, das trocas, da constante interação, privilegiando, além do cognitivo, o afetivo e o intuitivo, para potencializar estratégias didáticas que estabeleçam relaçóes que possam contribuir para a constituição de um conhecimento coletivo, levando o sujeito a atitudes de criação e autoria, acompanhando cognitivamente o processo de aprendizagem objetivado. 
Todavia, para a autonomia do aprendiz é cada vez mais urgente e necessário desencadear elementos que estabeleçam conexôes com a diversidade de ritmos, disponibilidades, interesses e a multiplicidade de tarefas de cada usuário, pois segundo Almeida e Valente (2011, p. 36), as TD podem

[...] potencializar as práticas pedagógicas que favoreçam um currículo voltado ao desenvolvimento da autonomia do aluno na busca e geraçáo de informaçóes significativas para compreender o mundo e atuar em sua reconstrução, no desenvolvimento do pensamento crítico e auto-reflexivo do aluno, de modo que ele tenha capacidade de julgamento, auto-realização e possa atuar na defesa dos ideais de liberdade responsável, emancipaçáo social e democracia.

No entanto, é preciso criar condições para que alunos e professores venham a utilizar as TD não somente em sala de aula, mas no seu cotidiano, pois, conforme Ramal (2003, p. 48), é preciso "dominar as linguagens, compreender o entorno e atuar nele, ser um receptor crítico dos meios de comunicação, localizar a informação e utilizá-la criativamente e locomover-se bem em grupos de trabalho e produção de saber", sendo autores da sua própria fala e do próprio agir, exercitando no dia a dia tarefas que permitam superar dificuldades e limitaçóes do seu navegar com as tecnologias, além de possibilitar momentos de comunicação e expressão.

Estas tecnologias podem otimizar o trabalho de sala de aula, mobilizar a socialização de saberes, a construção de sentidos no processo de ensino e de aprendizagem, reforçando a rápida e eficiente transmissão de informaçôes, criando condições para uma maior interação entre os sujeitos envolvidos num espaço fluido e dinâmico que permite a ação, a participação, a livre problematização, bem como a liberdade de expressão. 
Seja qual for a abordagem para o uso do WhatsApp na formação do pedagogo, é preciso que, ao realizar atividades educativas, elabore o seu planejamento a partir de estratégias didáticas e mecanismos de avaliação para atender aos objetivos e necessidades do grupo que sustentem um espaço que vai se desdobrando para uma diversidade de caminhos que não estabeleçam limites para a imaginação.

Com a utilização do WhatsApp nos espaços formativos é possível ampliar o espaço de sala de aula, favorecendo a emergência de novas possibilidades, em que conhecimentos podem ser construídos, interesses, necessidades e desejos podem ser compartilhados, constituindo-se numa participação coletiva e de forma intuitiva, além da capacidade de aprender e do talento para socializar o aprendizado (LUCENA et. al., 2016).

Com a inserção das inovações tecnológicas no contexto educacional, as instituições de ensino superior (IES) são desafiadas a observar, a repensar as práticas educativas, a sinalizar e construir novos modos de se relacionar com tais recursos e contribuir para com a consolidação de uma nova cultura de ensino e de aprendizagem, já que na sociedade atual a comunicação é cada vez mais audiovisual e interativa, e nela, imagem, som e movimento se complementam na constituição da mensagem.

Neste sentido, é preciso repensar a formação do pedagogo em situaçóes de ensino que possibilitem o uso de recursos tecnológicos para o auxílio e a implementaçáo de novas abordagens e estratégias didáticas, criando espaços ao enfrentamento de açóes que além da formação inicial, priorizem também cursos de aperfeiçoamento e formação continuada, oficinas online que envolvam atividades nas quais o professor possa experienciar os diferentes recursos tecnológicos.

As tecnologias móveis proporcionam dispositivos e uma variedade de aplicaçóes que podem facilitar a nossa prática pedagógica, ampliando possibilidades no ponto de vista educativo, já que oferecem múltiplas formas de representaçóes da informação 
e comunicação, diferentes formas de interação, capacidade de armazenamento e versatilidade na elaboração e desenvolvimento de materiais didáticos com o uso.

No contexto educacional, as tecnologias móveis vêm permitindo o surgimento de diferentes práticas inovadoras e colaborativas que favorecem o processo de ensino e de aprendizagem baseado em situaçóes problemas, nas quais os sujeitos envolvidos podem expressar-se, opinar, buscar e receber informaçóes de interesse, colaborar e gerar conhecimento por meio das diversas experiências socializadas.

Na medida em que os aplicativos móveis são disponibilizados e utilizados no contexto educacional, funcionam como interfaces que se unem por meio de diagonais e consolidam as interaçóes, a interatividade, a autonomia, a colaboração, a comunicação e a aprendizagem.

Ao integrar nos contextos formativos, essa relaçáo pode ser uma proposta enriquecedora e um processo contínuo de vivências incorporadas no cotidiano dos alunos e professores na busca da criação de sentidos, compreendendo as possibilidades de transformação da prática educativa a partir da utilização do WhatsApp e tais elementos com mais autonomia, capacidade de enfrentamento dos desafios do processo de construção do saber, alterando hábitos, valores, modo de pensar e de aprender com diferentes recursos tecnológicos cada vez mais sofisticados e integrados.

Não se pode mais encarar as tecnologias móveis como algo distante da realidade do professor, mas deve-se vislumbrar o potencial existente em cada uma destas tecnologias, não se limitando a execuções mecânicas, tendo apenas como finalidades a memorização e a reprodução do conteúdo exposto, pois a formação do pedagogo com a utilização do WhatsApp está diretamente relacionada com o enfoque, a perspectiva, a concepção que se tem da sua formação, de suas funçôes atuais, devendo ser concebida como reflexão, pesquisa, ação, descoberta, organização, fundamentação, 
revisão, construção teórica e não como mera aprendizagem de novas técnicas, atualização em novas receitas pedagógicas ou aprendizagem das últimas renovações tecnológicas.

\section{Contribuiçóes e as potencialidades do WhatsApp nos processos de orientaçáo e formaçáo de bolsistas do Programa Institucional de Bolsas de Iniciação Cientí- fica (PIBIC)/UFAL}

Os novos cenários requerem desenvolver nos professores em formação a habilidade, a competência para o uso das tecnologias móveis, de modo particular, o aplicativo WhatsApp, a agilidade de raciocínio mental e formal, autonomia e criatividade, para que os grandes desafios sejam superados nos processos formativos em sua docência. Considerar a importância dessa formação para a docência é superar limites no aprender a ser professor, que não é tarefa fácil, mas sempre um aprendizado por meio de situaçóes teóricas e práticas, com uma bagagem sólida no âmbito científico, atuando reflexivamente com flexibilidade e responsabilidade no trabalho docente.

Nesse âmbito, é necessário pensar numa concepção de formação que compreenda um conjunto possível de formas de interação e de cooperação entre pesquisadores, formadores, professores e outros atores do espaço acadêmico suscetíveis de favorecer a prática reflexiva e a profissionalização interativa a partir do WhatsApp, estimulando a sinergia das competências profissionais, o que poderá ser um caminho na identificação de novos questionamentos que permitirão reformas ou reestruturaçóes futuras nos cursos de formação de professores, abrindo espaço para dimensóes coletivas e cooperativas, já que é possível formar o professor em ambientes de aprendizagens diferentes (participativo, interativo, criativo, aberto, contextualizado, humano, justo). 
Esses espaços de aprendizagem se devem a uma proposta curricular aberta e flexível que regulamente soluçóes para problemas sociocognitivos comuns ao grupo e, por outro lado, se apoiem no trabalho cooperativo entre professores e formadores, explorando novas possibilidades de representação do conhecimento adquirido.

Sob este contexto, cada vez mais é necessária a discussão sobre a formação do professor com a utilização deste aplicativo, pois o conhecimento adquirido pelo docente nessa formaçáo deve ser instrumento de uma aprendizagem que constrói e reconstrói nas diversas situaçóes da vida em sociedade.

As tecnologias móveis podem proporcionar aos seus usuários, mediante recursos hipermidiáticos, isto é, a integração de várias mídias/linguagens, tais como textos, animaçóes, imagens, vídeos, sons e movimentos, situações de ensino e aprendizagem para alunos e professor, buscando assumir uma postura de sujeitos ativos, com capacidades argumentativa e reflexiva, à medida que constroem e reconstroem conceitos, apresentam estratégias didáticas por meio das diferentes funcionalidades desses ambientes.

As mudanças introduzidas pelo WhatsApp podem naturalmente contribuir para o enriquecimento progressivo dos ambientes e contextos de aprendizagem, revelando-se na possibilidade de criação dialógica propiciada pelas interaçôes de pensamentos, conceitos, imagens, mídias e ideias, nas quais o sujeito atua de forma consciente com os objetos do conhecimento na educação.

O WhatsApp invade os espaços de relaçóes, com a possibilidade de subsidiar diferentes práticas pedagógicas, de forma que seus usuários possam convertê-los num espaço rico em descobertas por meio da sua interatividade e na interação entre os pares. $\mathrm{O}$ Whats $A$ $p p$ tem a capacidade de facilitar as oportunidades de aprendizagem superior personalizada aos indivíduos, permitindo uma abertura e uma ligação ao mundo exterior. Nessa concepção, os usuários deste aplicativo devem ser encorajados a confrontar-se com a realidade, mostrando-se criativos a novas descobertas e alternativas inovadoras. 
A partir desse contexto, foi criado um grupo no Whats $A p p$ (FIGURA 1) com os dois bolsistas do PIBIC/UFAL com propósito de orientar, acompanhar e refletir sobre as atividades propostas para o desenvolvimento do projeto PIBIC, analisar as contribuiçóes e as potencialidades deste aplicativo para tal fim, refletir sobre a formação do pedagogo em face do WhatsApp por meio das interaçóes entre os sujeitos envolvidos por estratégias didáticas.

Figura 1 - Página inicial do grupo criado no Whats $A p p$

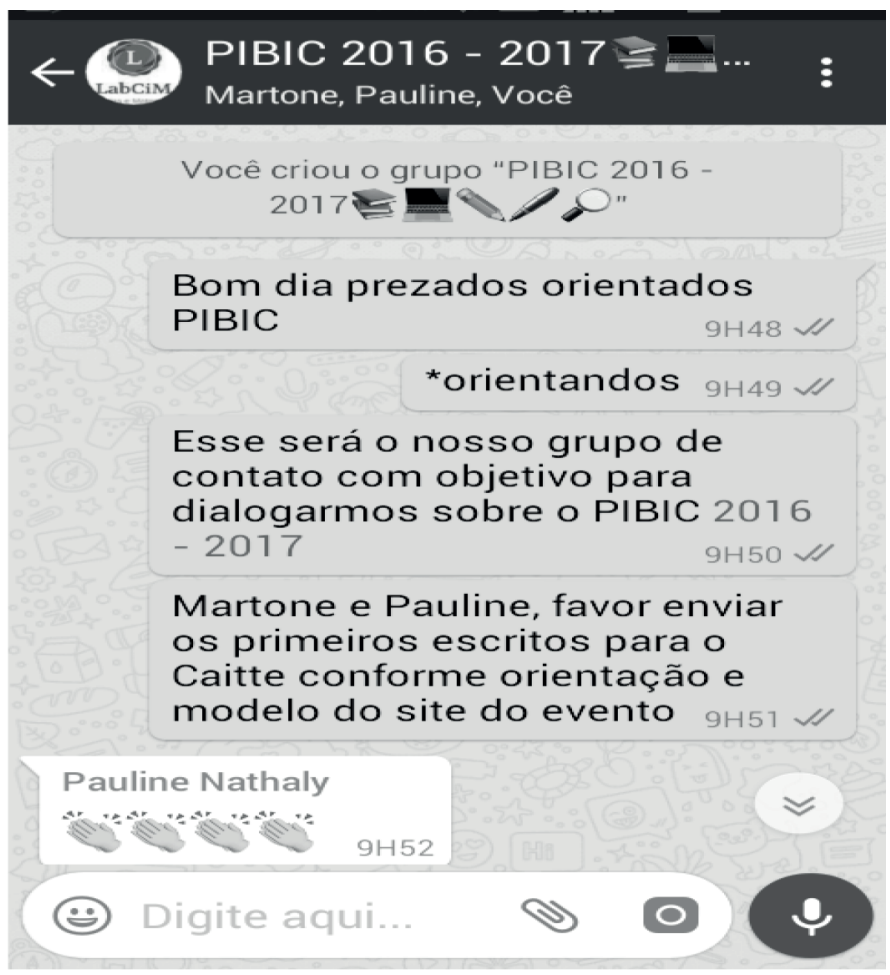

Fonte: Acervo do autor.

Com o grupo criado e apresentado, os orientandos foram convidados a utilizar ferramentas disponibilizadas pelo aplicativo 
WhatsApp, constituindo num espaço significativo que possibilitasse leituras, pesquisas, realização de atividades, desafios, construções e diálogos sobre as temáticas propostas ao longo das orientaçóes.

Depois de tomada de consciência dos bolsistas da criação do grupo no WhatsApp, os mesmos puderam utilizar o aplicativo como apoio aos diálogos e orientaçóes referentes ao cronograma proposto no projeto do PIBIC/UFAL, permitindo a troca e o compartilhamento de ideias, estando atento a algumas situaçóes, incorporando os papéis atribuídos, interagindo efetivamente ao longo das orientaçóes, mantendo uma troca constante de informaçóes, concedendo o direito de se expressar, de criar e recriar, de decidir, de optar e construir conceitos com autonomia e criticidade, conforme Figura 2.

Figura 2 - Interação do bolsista a partir da leitura de textos

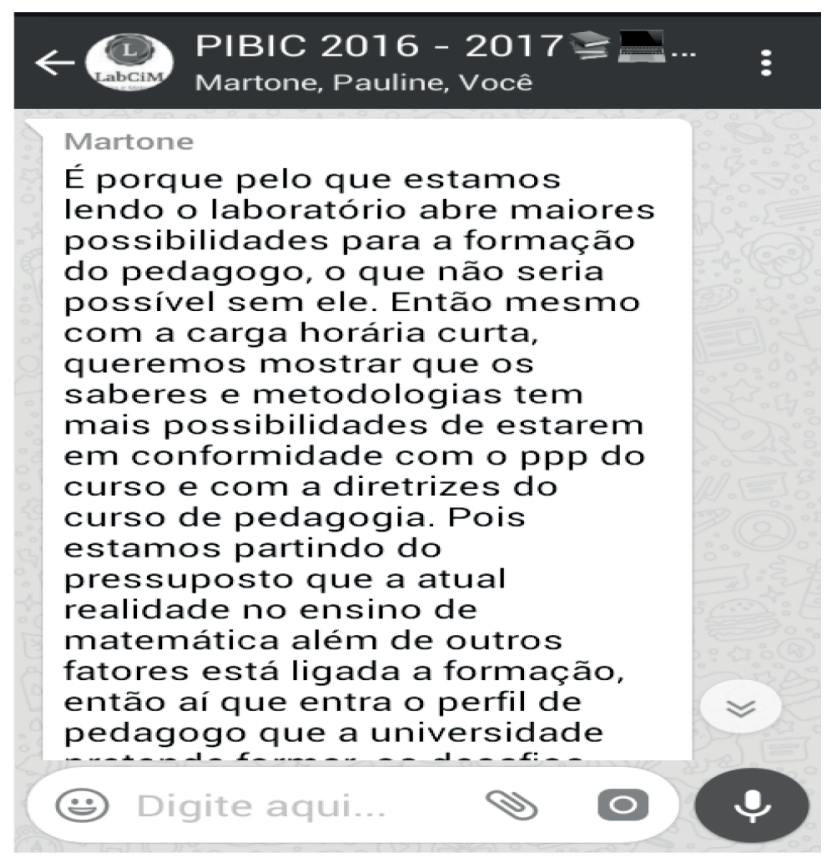

Fonte: Acervo do autor. 
Ao compreender a importância do WhatsApp na perspectiva da orientação e acompanhamento, foi possível também trocar informaçóes em arquivos (doc.), conforme Figura 3, a escrita dos relatórios solicitados sobre o desenvolvimento das atividades propostas para os bolsistas.

Figura 3 - Envio do relatório parcial sobre o desenvolvimento das atividades

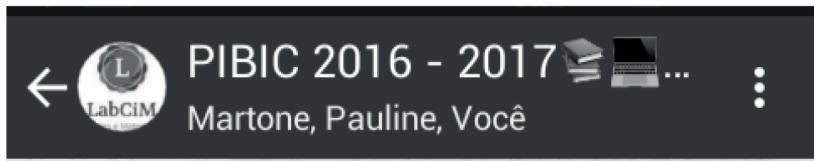

Bom dia $10 \mathrm{H} 04 \mathrm{~V}$

Enviem por aqui em arquivo o relatório parcial urgente $10 \mathrm{HO} / \mathrm{V}$

\section{Martone}

$\equiv 1^{\circ}$ Versão - Martone - Rel...

Obrigado Martone! 11 H09 $\mathrm{W}$

Aguardando o de Nathaly!

$11 \mathrm{H} 09 \mathrm{~V}$

Fonte: Acervo do autor

Com a intenção de levar ao conhecimento dos sujeitos a importância de se trabalhar com o WhatsApp, visando a uma aprendizagem no sentido mais abrangente, foi possível também fortalecer a ideia da autonomia e da criatividade dos orientandos para além 
da escrita, enviando imagens, fotos, vídeos, áudios e/ou links (FIGURA 4), apontando recomendaçóes que permitiam o desenvolvimento de diferentes estratégias de diálogo e orientação.

Figura 4 - Envio de imagens/fotos

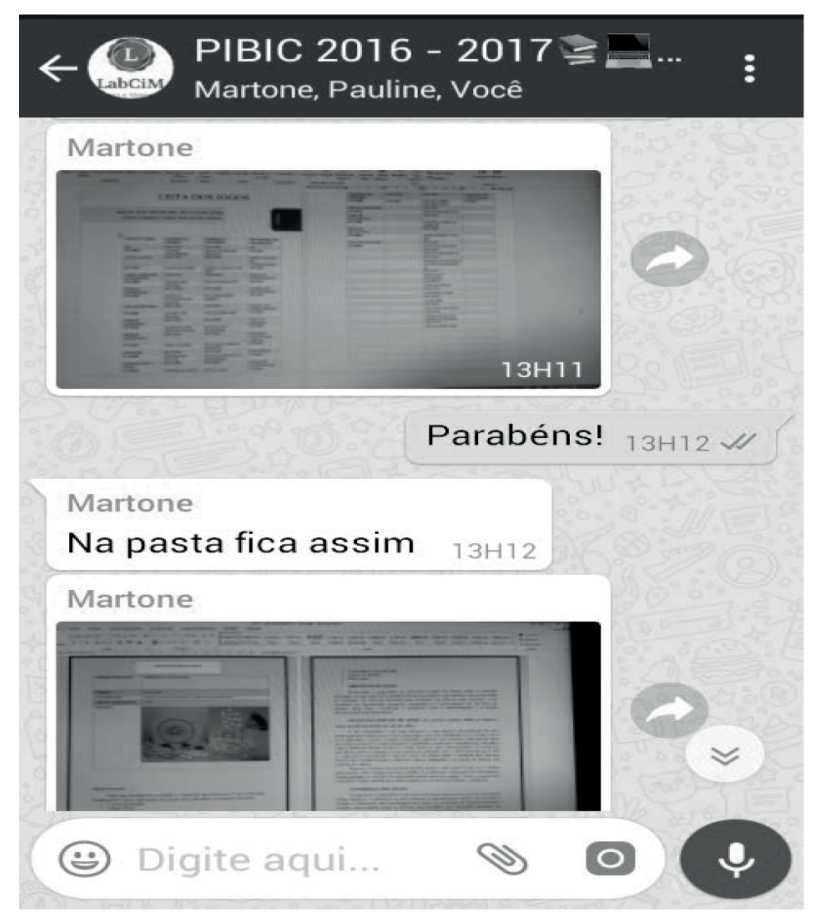

Fonte: Acervo do autor

Criar espaços de formação do professor mediante os aplicativos móveis é urgente na sociedade midiática em que se vive. As rápidas mudanças sociais via desenvolvimento tecnológico atingem a educação na contemporaneidade, sendo possível estabelecer, por meio da ampliação desses espaços híbridos e criativos, dimensōes pedagógicas nas formas de ensinar e de aprender, gerando dinâmicas que se relacionam e se articulam com os saberes-fazeres. 
Dessa forma, percebemos que é possível integrar recursos midiáticos para a formação de cada sujeito, o que requer por parte do professor uma melhor percepção do processo educacional nestes ambientes e uma melhor identificação dos atores e seus papéis no desenvolvimento da prática educativa, baseada num conjunto de conteúdos curriculares a partir de estudos, pesquisas, atividades acadêmicas e extracurriculares.

A utilização do WhatsApp abre novos espaços para a formação do professor e impóe muitos desafios às IES. Vão além do recebimento de informaçóes, desenvolvem habilidades intelectuais de escrita, leitura do ambiente, criatividade, curiosidade, interpretação, para a resolução de problemas e estratégias didáticas, como ocorre com o raciocínio, a atenção ou a sociabilidade de conhecimentos prévios e/ou adquiridos, contribuindo na construção de novos sujeitos sociais capazes de interferir no processo de transformação da sociedade.

\section{Consideraçóes finais}

O desejo de uma melhor participação e a interação no Whats $A p p$ foram condiçóes mencionadas pelo grupo de orientandos. Eles assumiram que precisavam ser sujeitos ativos do processo a partir das interfaces disponibilizadas no aplicativo, para que pudessem superar seus limites e as dificuldades encontradas durante a sua utilização, pois quanto maiores as interaçóes, maior a sistematização dos conteúdos propostos. Já o encontro com a diversidade de ideias possibilitará significados que lhes permitam pesquisar e pensar criticamente.

Os orientandos buscaram aprender de forma cooperativa, sem as limitaçóes de barreiras geográficas e de tempo, melhorando a qualidade da sua navegabilidade no ambiente, respeitando o pensamento do colega, visando enriquecer sua própria aprendizagem e 
desenvolver a autonomia para compartilhar seus objetivos, conteúdos estudados, suas metas e soluções de problemas que surgiram durante as orientaçóes.

Ao considerar o contexto do WhatsApp na formação do pedagogo, necessitamos de olhares que proporcionem estilos de compreensão, processamento e análises em torno desses ambientes como estratégias didáticas, não apenas para a manipulação de conteúdos e leituras exigidas, mas para compartilhamento de ideias e obtenção de conhecimentos, de acordo com suas necessidades, visando suas condiçóes intelectuais ou interesses específicos.

Precisamos, no WhatsApp, acompanhar os alunos, orientar e problematizar os conteúdos propostos, para que esses alunos sejam capazes de transformar as informaçóes transmitidas e/ou pesquisadas em conhecimento, por meio dos recursos e propostas que envolvam ações reflexivas. Esse ambiente deve propiciar ao aluno a ampliação de oportunidades para a construção do conhecimento.

Necessita-se de olhares que articulem, por meio do WhatsA$p p$, um espaço para o compartilhamento de saberes e experiências, que facultem aos sujeitos posturas investigativas e multiplicadoras de concepções que permitam exercer uma posição crítica ante a sua realidade, interrogando-a, buscando alternativas teóricas e práticas diante de suas problemáticas.

\section{Referências}

ALMEIDA. M. E. B.; VALENTE, J. A. Tecnologias e currículo: trajetórias convergentes ou divergentes? São Paulo: Paulus, 2011.

\section{BEHRENS, M. A. Tecnologia interativa a serviço da} aprendizagem colaborativa num paradigma emergente. 2011. Disponível em: <http://www.tvebrasil.com.br/salto/ boletins2011>. Acesso em: 28 mar. 2013. 
LUCENA, S. et al. Redes e fluxos na iniciação à docência: o Whatsapp Messenger como espaço tempo de formação no Programa Institucional de Bolsas de Iniciação à Docência. In: COUTO, E.; PORTO, C.; SANTOS, E (Org.). App-learning: experiências de pesquisa e formação. Salvador: EDUFBA, 2016.

MARINHO, S. P. et al. Tecnologias móveis, mídias e redes sociais: cultura de uso de estudantes de Licenciatura. In: Congresso Brasileiro De Informática Na Educação (CBIE-LACSO), 4., 2015, Maceió. Anais... Maceió: SBC, 2015. p. 834-843. Workshop.

PAPERT, S. A máquina das crianças: repensando a escola na era da informática. Porto Alegre: Artes Médicas, 1994.

RAMAL, A. C. Educação a distância: entre mitos e desafios. In: ALVES, L.; NOVA, C. (Org.). Educaçáo a distância: uma nova concepção de aprendizado e interatividade. São Paulo: Futura, 2003. p. 43-50.

SANTAELLA, L. Comunicação ubíqua: repercussões na cultura e na educação. São Paulo: Paulus, 2013.

VALENTE, J. A. Aprendizagem e mobilidade: os dispositivos móveis criam novas formas de aprender? In: ALMEIDA, M.E.B.; ALVES, D.R.M.; LEMOS, S.D. (Org.). Webcurrículo: aprendizagem, pesquisa e conhecimento com o uso de tecnologias digitais. Rio de Janeiro: Letra Capital, 2014. p. 39-56.

\section{VALENTE, J. A. As tecnologias digitais e os diferentes}

letramentos. Porto Alegre: Pátio, 2007. 


\title{
DIÁRIO ONLINE NO WHATSAPP: APP-LEARNING EM CONTEXTO DE PESQUISA-FORMAÇÁO NA CIBERCULTURA
}

\author{
Alexsandra Barbosa - UERJ \\ Edméa Santos - UERJ \\ Mayra Ribeiro - UERN
}

\section{Introdução}

A cultura contemporânea tem proporcionado diferentes usos das tecnologias móveis no âmbito da educação, tais como a utilização de celulares, smartphones e tablets na pesquisa e na formação de professores. Os aplicativos têm possibilitado situações de aprendizagem nas quais os sujeitos interagem e aprendem em mobilidade e ubiquidade, possibilitando, assim, novos modos de produção de saberes.

Neste cenário, ao articularmos essas tecnologias com a pesquisa-formação na cibercultura, o App-Learning, modo como chamamos os saberesfazeres ${ }^{l}$ provenientes do uso de aplicativos nos processos de aprendizagemensino, também pode ser utilizado nas pesquisas como dispositivos que registram por meio da escrita, da fotografia, de áudios e de vídeos o que é vivenciado na pesquisa. Refletindo sobre esses usos, o aplicativo Whats App Messenger foi utilizado como diário online

1 Inspirados em Alves (2008), as pesquisas cotidianistas utilizam essa forma de escrita com os neologismos como dentrofora, saberesfazeres, espaçotempo, etc., para marcar a ruptura com a dicotomizaçáo da concepção de ciência moderna. 
no processo formativo de uma pesquisa-formação na cibercultura no contexto do Grupo de Pesquisa Docência e Cibercultura² (GPDOC).

Os praticantes culturais na cibercultura utilizam as tecnologias da web 2.0 com os mais variados propósitos interativos: discussôes de temáticas atuais do cotidiano, compartilhamento de momentos pessoais, informações acadêmicas, produção e divulgação de textos, vídeos, fotos, bate-papo, entre outros. A sociedade em rede se integra ao quotidiano, ligando o mundo real ao virtual com tanta intensidade que essa distinçáo, principalmente na geraçáo mais jovem, deixa de fazer sentido (AMANTE, 2014).

Nesse contexto, o diário online se constitui em um dispositivo potencializador do dizer da formação e da pesquisa em processo de sua tessitura, possibilitando o registro de narrativas digitais possíveis de serem revisitados, ressignificados e publicizadas a partir da bricolagem com a pluralidade de vozes que habitam o espaço na relação com as inspirações epistemológicas e metodológicas de opção do pesquisador. Mediação, problematização, colaboração, reflexão, interação, autoria, alteração e (trans)formação são algumas das noçóes que atribuímos sentido, quando produzimos dados da pesquisa-formação junto com outros praticantes culturais nas redes digitais, no caso específico, no Aplicativo WhatsApp Messenger.

$\mathrm{Na}$ itinerância formativa do grupo de pesquisa em docência e cibercultura da UERJ, atualizamos o método da pesquisa-formação na cibercultura sempre que habitamos com intencionalidade de pesquisa os ambientes on-line. Nossa tessitura metodológica se inova a cada pesquisa em um processo de criação de dados em/ nas redes (SANTOS, 2014) junto com os coautores, produtores de sentido por meio de narrativas digitais escritas, orais e em imagens.

Propomos neste texto pensarmos sobre as possibilidades de usos do dispositivo WhatsApp Messenger como diário on-line em um

2 Sites do Grupo de Pesquisa Docência e Cibercultura <www.docenciaonline.pro.br>, $<$ www.proped.pro.br> . 
espaçotempo de produção de narrativas digitais instigadas por diálogos plurais, interatividade, colaboração e ampliação dos sentidos de si, pesquisador autoformador, e dos sentidos da/na relação com os outros sujeitos coautores.

\section{Cordel do WhatsApp}

por Izabel Nascimento

Esse tal de "Zap Zap"

É negócio interessante

Eu que antes criticava

Hoje teclo à todo instante

Quase nem durmo ou almoço

E quem criou esse troço

Tem uma mente brilhante.

Quem diria que um dia

Eu pudesse utilizar

Calculadora e relógio

Câmera de fotografar

Tudo no mesmo aparelho

Mapa, calendário, espelho

E telefone celular

E agora a moda pegou

Pelas "Redes Sociais"

É no "Face" ou pelo "Zap"

Que o povo conversa mais

Talvez não saiba o motivo

Que esse tal de aplicativo

É mais lido que os jornais.

Eu acho muito engraçado

Porque muita gente tem

Um Grupo só pra Família

Um do Trabalho também 
E até aquele contato

Que só muda de retrato

Mas não fala com ninguém!

Tem o Grupo da Escola

O Grupo da Academia

Grupo da Universidade

O Grupo da Poesia

Tem o Grupo das Baladas

Das Amigas Mais Chegadas

E o da Diretoria.

Tem quem mande Oração

"Bom dia!", de vez em quando

Quem só mande figurinhas

Quem só fique reclamando

Nos Grupos é que é parada

Dia, noite, madrugada

Sempre tem alguém teclando.

Cada um que analise

Se é bom ou se é ruim

Ou se a Tecnologia

É o começo do fim

Talvez um voto vencido

Porém o Zap tem sido

Até útil para mim.

Eu acho que a Internet

É uma coisa muito boa

Tem coisas muito importantes

Porém muita coisa à toa

Usar de forma acertada

Ou, por ela, ser usada

Vai depender da pessoa.

Comunicação é bom

Vantagens que hoje se tem 
Feliz é quem tem amigos

Fora das Redes também

A vida só tem sentido

Quando o que é permitido

É aquilo que convém.

Pra quem meu verso rimado

Acabou de receber

Compartilhe esta mensagem

Que finaliza a dizer:

"Viva a vida intensamente

Porque é pessoalmente

Que se faz acontecer!"

\section{Diário online como dispositivo para App-learning}

O diário é fundamental para as pesquisas qualitativas tendo em vista o caráter subjetivo estabelecido entre o pesquisador e seu objeto de estudo. Historicamente, a técnica do diário de itinerân$\mathrm{cia}^{3}$ foi importada da etnologia, que é um ramo da antropologia que estuda os povos e sua cultura. Os diários que inicialmente possuíam apenas um "caráter íntimo" (MEDRADO; SPINK; MÉLLO, 2014) passaram a fazer parte da metodologia de pesquisa utilizada por antropólogos ao fazerem uso dos "diários de campo" em seus estudos.

Para Barbosa e Hess (2010, p. 73, grifos nossos), o diário pode assumir diferentes tipos:

Diário de formação: quando se propóe a registrar o próprio processo formativo vivenciado no decorrer de um curso seja de graduação, pós-graduação ou outro;

3 Trata-se de um instrumento de investigação sobre si mesmo em relação ao grupo e em que se emprega a tríplice escuta/palavra - clínica, filosófica e poética - da abordagem transversal. Bloco de apontamentos no qual cada um anota o que sente, o que pensa, o que medita, de uma conversa, o que constrói para dar sentido à sua vida (BARBIER, 2002, p. 133) 
Diário pessoal: quando o objetivo é registrar tudo o que se refere a sua própria vida ou como rebate dentro de si o vivido, seja da ordem da saúde, das emoçóes, das questôes existenciais e filosóficas;

Diário de pesquisa: quando o objetivo é registrar o caminho percorrido, ao desenvolver uma pesquisa como TCC, dissertação de mestrado ou tese de doutorado.

Todos eles têm o objetivo de registrar e organizar situaçóes vividas pelo sujeito em seu cotidiano. Zabalza (1994, p. 96) discorre sobre a implicação pessoal daquele que realiza seu diário no qual "o diário é antes de tudo alguma coisa que alguém escreve de si para si mesmo: o que se conta tem sentido, unicamente para aquele que é ao mesmo tempo autor e principalmente destinatário da narração". Sendo assim, é no diário que traduzimos em imagens, sons e narrativas nossas impressóes imediatas que posteriormente se tornaráo alicerces para a compreensão do que foi vivido.

Os diários em uma perspectiva multirreferencial, nossa opção epistemológica de pesquisa, possibilita uma "leitura plural de seus objetos (práticos ou teóricos), sob diferentes pontos de vista, que implicam tanto visóes específicas quanto linguagens apropriadas às descrições exigidas, em função de sistemas de referenciais distintos, considerados e reconhecidos explicitamente como não redutíveis uns aos outros, ou seja, heterogêneos" (ARDOINO, 1998, p. 24). Essa perspectiva plural e heterogênea realizada pelo pesquisador em seus diários ocorre quando em seu trabalho há uma confluência entre os registros contidos nos diários de formação, pessoais e de pesquisa, proporcionando uma aprendizagem que considera a complexidade das situaçóes vividas. Nesse sentido, o diário é um dispositivo favorável a uma postura de um pesquisador multirreferencial e implicado com/no processo de auto-hetero-ecoformação Inspiramo-nos em Pineau (apud MACEDO, 2010, p. 67), para pensarmos e fazermos pesquisa implicados com essas três im- 
bricadas e distintas dimensões da formação; a autoformação nos diz respeito a nossa própria "condição de seres que interpretam, filtram o mundo e reconstroem incessantemente, e que, ademais sabem/ sentem, que algumas experiências da compreensão irrompem também fora das lógicas cognitivas da construção que conhecemos". Envolve processos de conhecer a si, a autocrítica e autonomizaçáo, na perspectiva de uma formação para/na alteridade.

A heteroformação nos coloca na condição de seres em relação, ou seja, a aprendizagem é, por natureza, relacional. Forma-se, assim, um contato permanente consigo, com o outro e com o mundo numa ambiência de diversidade e heterogeneidade ineliminável. A ecoformação envolve a relação entre o humano e o ambiente. É na dinâmica entre a auto-hetero-ecoformação que entendemos estar a complexidade da trans(formação).

$\mathrm{Na}$ pesquisa-formação, o ato de pesquisar está intrinsecamente relacionado com o processo de formaçáo do professor/ pesquisador; portanto, uma experiência de cunho pessoal pode enriquecer e agregar sentidos para a compreensão do objeto de estudo.

Seja ele escrito, fotografado ou filmado, o diário torna-se um dispositivo ${ }^{4}$ fundamental para a autoria nos trabalhos científicos, pois ao narrar a pluralidade de saberes e sentidos existentes no universo de práticas, experiências e teorias que vivemos ao pesquisar, ampliamos nossas reflexóes e desenvolvemos saberes que potencializam nossa escrita e nossa possibilidade de ampliação de um olhar para a complexidade do objeto de estudo, no qual, como pesquisadores, estamos incluídos.

$\mathrm{O}$ ato de dialogar com nossas experiências formativas, por meio dos diários, oportuniza não somente um processo de autoria na escrita de textos acadêmicos, mas também de uma re-escrita

4 Essa noção de dispositivo aqui usada é de Ardoino (2003, p. 80) que conceitua dispositivo como "uma organização de meios materiais e/ou intelectuais, fazendo parte de uma estratégia de conhecimento de um objeto". 
de nós mesmos, das nossas ideias e sentimentos, transformando-os continuamente a cada vez que reescrevemos nossas narrativas.

O pesquisador, na pesquisa-formação, que faz uso do diário enriquece sua formação teórico-prática-existencial, em uma relação híbrida resultante da relação entre razão e subjetividade. Reflexão e reflexividade se complementam na tessitura de uma itinerância ${ }^{5}$ que se permite registrar impressóes, angústias, desejos, aprendizagens e questionamentos como extensão de sua memória no campo de pesquisa com os praticantes culturais ${ }^{6}$. No entanto, o diário não serve apenas para preservar as memórias do objeto de estudo; uma vez que, ao relatar, ao conversar e detalhar, também nos tornarmos parte do campo de pesquisa (MEDRADO; SPINK; MÉLLO, 2014, p. 273-274). Nele nossas escolhas e interpretações estão impressas.

Assim, como nos tornamos parte do campo no qual estamos "mergulhados" (ALVES, 2008), igualmente pertencemos a um contexto histórico e social que atualmente é marcado pelo uso de tecnologias móveis situados na cultura contemporânea mediada pelo digital em rede em mobilidade e ubiquidade, isto é, na cibercultura.

Isto significa que a cibercultura na pesquisa e formação de professores cria possibilidades interativas e hipertextuais devido à potência trazida pela linguagem digital, que revoluciona as formas de registro e de comunicação entre os indivíduos. Diante disto, os diários passaram a ocupar não apenas o suporte material em cadernos e blocos de anotaçóes, mas, o suporte digital, por meio de blogs, redes sociais e aplicativos, que além da escrita registram fotos, áudios e vídeos do que é vivenciado.

A mobilidade e a ubiquidade trazidas pelo digital em rede por meio dos aplicativos disponíveis para dispositivos móveis

5 Itinerância "representa um percurso estrutural de uma existência concreta tal qual se manifesta pouco a pouco, e de uma maneira, inacabada, no emaranhado dos diversos itinerários percorridos por uma pessoa ou por um grupo" (BARBIER, 2002, p. 134).

6 Termo usado por Certeau (2014) para aquele que vive as práticas/táticas cotidianas. 
(smartphones e tablets) ressignificam os espaçostempos plurais de aprendizagem proporcionando novos desafios e dinâmicas educacionais aos processos de pesquisa, ensino e aprendizagem. Chamamos esses processos provenientes de saberesfazeres por meio do uso de aplicativos por docentes e discentes de $A p p$ learning (SANTAELLA, 2016).

Dentro do universo de $A p p s^{7}$ existentes nas lojas de aplicativos online, alguns nos dão a possibilidade de, ao utilizá-los, realizarmos práticas interativas e hipertextuais na pesquisa-formação na cibercultura. Essas práticas com aplicativos têm estabelecido novos modos dos indivíduos se autorizarem e se comunicarem, por exemplo, por meio dos diários online.

Temos, estabelecendo uma relação entre a prática do diarismo online interativo e hipertextual com Apps e a obra Parangolé de Hélio Oiticica, a noção de que:

Rompe com o modelo comunicacional baseado na transmissáo. E é pura proposição à participação ativa do 'espectador' - termo que se torna inadequado e obsoleto... Oiticica quer a intervençáo física na obra de arte e não apenas a contemplação imaginal separada da proposição. $\mathrm{O}$ fruidor da arte é solicitado à 'complementação' dos significados propostos no $\mathrm{Pa}$ rangolé. E as proposiçóes são abertas, o que significa convite à co-criação da obra. (SILVA, 2010).

Consideramos que o processo autoral para realização de um trabalho científico, apoiado pelo uso de diários online, pode ser entendido como uma obra aberta. Um livro, um artigo, uma dissertação ou tese é um convite à cocriação, pois servirá para que outros autores dialoguem e intervenham, criando novas ressonâncias, novas autorias. O leitor de um trabalho científico não é um "mero

7 O termo 'App' em português significa aplicativo, que são programas que podem ser baixados para o celular, por meio das lojas de aplicativos online. 
espectador"8 (SILVA, 2014), ele pode propor criaçôes outras, interferindo e não apenas contemplando.

Ao pensarmos em um diário online com interface interativa e hipertextual, que possibilitasse ao professor/pesquisador criar sua obra em mobilidade e ubiquidade em uma das pesquisas realizada pelo Grupo de Pesquisa Docência e Cibercultura (GPDOC), o aplicativo WhatsApp foi escolhido para ser nosso dispositivo multirreferencial sendo um dos nossos desafios explorar seu potencial para registros e narrativas de pesquisa.

\section{O WhatsApp como diário online}

O WhatsApp Messenger é um aplicativo gratuito de mensagens instantâneas, chamadas por voz e vídeo para Smartphones. Ele foi criado em 2009 por Brian Acton e Jan Koum e comprado em 2014 pela Rede Social Facebook ${ }^{2}$. Este ano atingiu mais de 1 bilhão ${ }^{10}$ de usuários no mundo.

Ao considerar as potencialidades desse aplicativo como dispositivo de relaçóes intersubjetivas, de cocriação, de autoria e, consequentemente, de um agenciamento de saber-poder (SANTAELLA, 2013), apresentamos uma experiência do GPDOC ao fazer uso do WhatsApp como diário online, realçando as possibilidades de usos e registros autorais.

\section{Do suporte físico para o suporte digital (digitalizaçáo)}

Com o uso do aplicativo, o suporte - antes físico, como a página de um livro, por exemplo - passou a ser um material digital.

8 Silva (2014, p. 19) chama de novo espectador aquele que convive com "a máxima concentraçáa de informaçóes num mínimo espaço-tempo", que dialoga e interfere nos conteúdos hipermidiáticos e hipertextuais.

9 O Facebook é uma rede social que foi criada em 2004, por Mark Zuckerberg e atualmente é a rede social mais usada em todo o mundo.

10 https://pt.wikipedia.org/wiki/WhatsApp 
Isto foi realizado pelo WhatsApp por meio de fotografia. O fato de digitalizarmos o material antes impresso proporcionou agilidade para localização dos registros do diário, facilitando a escrita de textos acadêmicos.

A materialização do livro em bits por meio do digital possibilita que o mesmo seja reproduzido, alterado e compartilhado em rede. A digitalização possibilita a prática de diálogo mais interativo, pela digitalizaçáo de sons, imagens e textos.

$\mathrm{O}$ digital conectado à internet potencializa ainda mais os processos de aprendizagem, para Santos (2014, p. 59) “o ciberespaço surge não só por conta da digitalização, evolução da informática e suas interfaces, própria dos computadores individuais, mas da interconexão mundial de computadores, popularmente conhecida como internet", a digitalização provoca mudanças sociotécnicas que permitem novas formas de aprendizagem e ensino.

Figura 1 - Print do Diário online no WhatsApp - trecho de livro

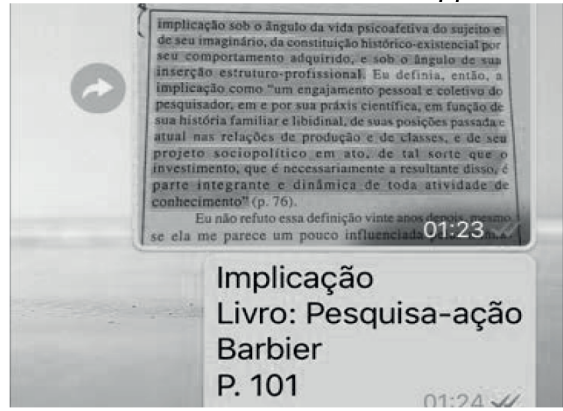

Fonte: Print de tela de Alexsandra Barbosa (22/11/2016)

\section{Compartilhamento de mídias da web (Hipertextualidade)}

O hipertexto se constitui "em um conjunto de nós ligados por conexóes. Estes nós ou links são elos entre textos e hipertextos que podem ser imagens, palavras, páginas ou outro hipertexto" (LÈVY, 1993, p. 33). Ao navegar na internet, realizando pesquisas, 
leituras de artigos, visitando blogs, revistas científicas, conteúdos de redes sociais, jornais online, assistindo vídeos no Youtube, dentre outras mídias, os links podem ser encaminhados entre os participantes e servem de referencial de pesquisa no aplicativo.

O hipertexto possibilita ao leitor criar seus próprios caminhos de leitura, de aprendizagem, explorando a pluralidade de saberes e de fontes; deixando de estar preso, encerrado no que lhe é apresentado.

Figura 2 - Print do Diário online no WhatsApp - links e vídeos

\begin{tabular}{|c|c|}
\hline $\begin{array}{l}\text { Palestra de Abertura } \\
\text { Dra Edmea Santos } \\
\text { www.youtube.com }\end{array}$ & $\begin{array}{l}\text { Imprensa Nacional - } \\
\text { Visualização dos Jornais } \\
\text { Oficiais } \\
\text { pesquisa.in.gov.br }\end{array}$ \\
\hline $\begin{array}{l}\text { http:|/.youtu.be/. } \\
\text { EdFnyDS7ELw }\end{array}$ & $\begin{array}{l}\text { http://.pesquisa.in.gov.br/. } \\
\text { imprensa/jsp/visualiza/. }\end{array}$ \\
\hline $\begin{array}{l}\text { Palestra de Abertura } \\
\text { Dra Edmea Santos } \\
\text { Parte2 }\end{array}$ & $\begin{array}{l}\text { data }=11 / 10 / 2016 \& \text { jornal }= \\
1 \& \text { pagina }=21 \& \text { totalArquiv }\end{array}$ \\
\hline www.youtube.com & $\underline{O S=Z T 2} \quad 23: 50 \mathrm{~W}$ \\
\hline Links de Vídeos & Links de documentos \\
\hline
\end{tabular}

Fonte: Print de tela de Alexsandra Barbosa (16/10/2016).

Nessa lógica, os processos comunicativos e interativos se tecem rizomaticamente nas redes sociais digitais baseados nos princípios de reciprocidade, participação e compartilhamento.

\section{Agrupamento de mídias (Plasticidade)}

O digital em rede promove plasticidade, que é a forma de flexibilidade, adaptabilidade existente na forma de construção do conhecimento. $\mathrm{O}$ conceito de plasticidade é oriundo de estudos 
neurocientíficos sobre a plasticidade sináptica, no qual grupos de neurônios assumem funçôes de outros, formando redes. Bruno (2010, p. 47) cita cinco características da plasticidade que podem ser ressaltadas no contexto sociocultural e tecnológico. São elas:

a) flexibilidade: rompe com as barreiras que impediriam desdobramentos e integraçóes de ideias, de pessoas, de informaçôes, de conhecimentos, de funçôes, pois cria trilhas de possibilidades e emergências;

b) conectividade: possibilidade de interligaçấo de temas e experiências, de modo a se desdobrar em outras conexóes / ligaçóes sem forma definida;

c) integração: diferente de agrupamento, esta característica indica os processos decorrentes entre eventos plurais, não fragmentando ou excluindo grupos e contextos, mas criando elos de ligação;

d) abertura: com sistemas de entradas e saídas múltiplas, em fluxo e em constante emergência, a plasticidade não possui uma organização ou estrutura pré-estabelecida - não são fixas;

e) dinamicidade: como organismos vivos e em constante devir, os elos se interconectam e se integram (desintegram / reintegram), mas se re/ desconstituem por meio de conflitos, assumindo funçôes, até aquele momento, inimagináveis.

O aplicativo WhatsApp organiza e separa os diferentes tipos de mídias (texto, imagem e som) que foram compartilhados de modo cronológico. Este deslocamento para que os arquivos sejam agrupados por tipo de mídia se deve à plasticidade do digital. Este movimento não seria possível se o diário fosse um caderno físico. A flexibilidade do diário online agrupa os fragmentos compartilhados e assim como um organismo vivo eles se desintegram e reintegram, criando suas ligaçóes, enriquecendo o processo de registro e diálogo do autor com o material de pesquisa. 
Figura 3 - Print do Diário online no WhatsApp-junção de links e vídeos

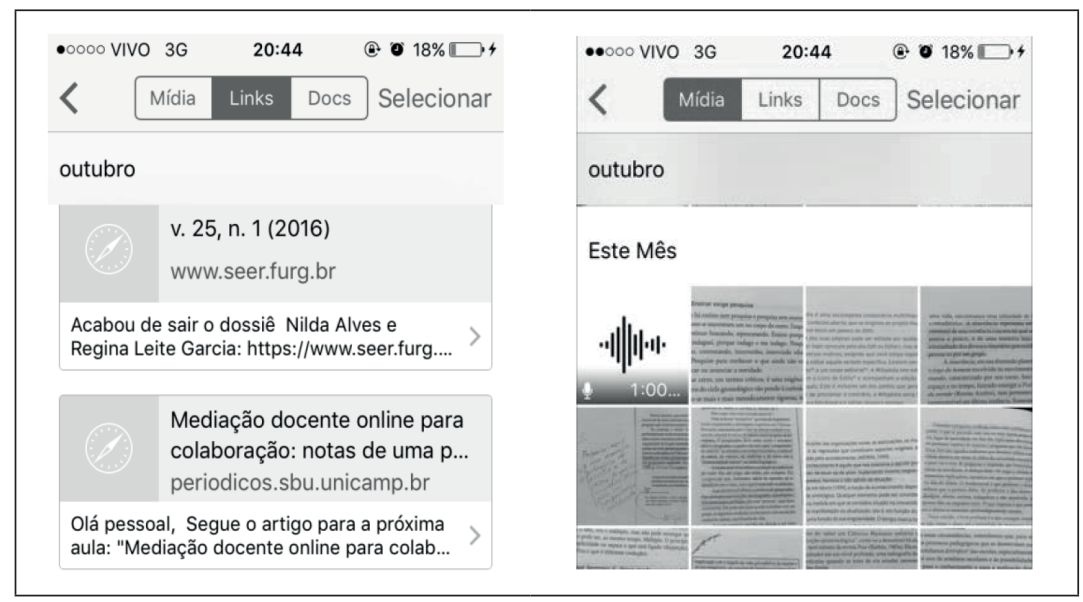

Links

Fotos e áudios

Fonte: Print de tela de Alexsandra Barbosa (16/10/2016).

\section{Pesquisa semântica (Indexaçáo)}

O aplicativo possibilita a realização de pesquisas por palavras, expressóes ou frases. No exemplo da figura 4, buscamos por "pesquisa-formaçáo" e o App relacionou todas as mensagens que continham a expressão.

Navegar pelos diálogos pesquisados propóe uma leitura plural do objeto de interesse. Conseguimos encontrar e estabelecer relaçôes entre conversas em grupo ou individuais sobre o assunto, possibilitando, desta forma, coautoria e diálogo.

A indexação é uma técnica que de acordo com Vieira (1988, p. 43) "condensa a informaçáo significativa de um documento, através da atribuiçáo de termos, criando uma linguagem intermediária entre o usuário e o documento", essa indexação pode ser manual (realizada pelo homem) ou automática (realizada por programas de computador). No caso do WhatsApp, ela é realizada manualmente com a criaçáo de hiperlinks. 
Figura 4 - Print do Diário online no WhatsApp - Pesquisando por palavra

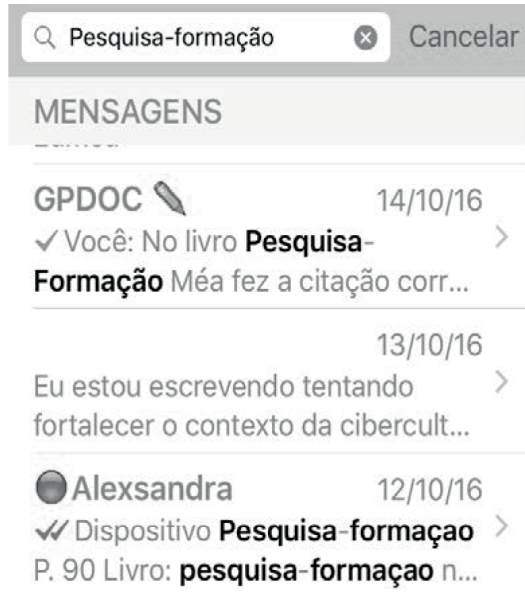

Fonte: Print de tela de Alexsandra Barbosa (16/10/2016).

\section{Compartilhamento em rede (Interatividade)}

A interatividade rompe com uma aprendizagem linear e se funda na cocriação por meio da liberação do polo de emissão, no qual a mensagem náo está restrita apenas a um emissor.

Importante destacar que Silva (2014) diferencia interação de interatividade. $\mathrm{Na}$ interação o sujeito interage com o material disponibilizado para estudo, não há possibilidade de intervenção para cocriação, o conceito de aprendizagem está mais relacionado à autoaprendizagem. Para que exista interatividade é necessário que o sujeito intervenha fisicamente, que transforme e crie numa relação dialógica com seus pares. Para Silva (2010, p. 42):

Interatividade é a modalidade comunicacional que ganha centralidade na cibercultura. Exprime a disponibilização consciente de um mais comunicacional de modo expressamente complexo presente 
na mensagem e previsto pelo emissor, que abre ao receptor possibilidades de responder ao sistema de expressão e de dialogar.

Neste contexto interativo e hipertextual, a mobilidade e a ubiquidade proporcionam um novo processo de aprendizagem, pois se cria um novo modo de ler e navegar pela internet. Por meio de uma leitura hipermidiática presente nos dispositivos móveis com as redes sem fios, espaços físicos e digitais se imbricam de tal modo que não há mais a percepção de acessarmos/entrarmos na internet, como ocorria com a internet discada. As informações disponibilizadas online podem ser cocriadas e compartilhadas.

O WhatsApp permite o compartilhamento em rede de todas as mídias e conversas produzidas no aplicativo. Os diálogos podem ser exportados para outros Apps que o usuário tenha instalado no smartphone; como, por exemplo, o Evernote, o Telegram, o Dropbox, o Google Drive, Gmail etc. Ao compartilhar em rede com seus aplicativos, é possível garantir cópias de segurança do diário online, além de permitir o diálogo e interatividade com outras pessoas em outras interfaces.

Figura 5 - Print do Diário online no WhatsApp compartilhando documentos

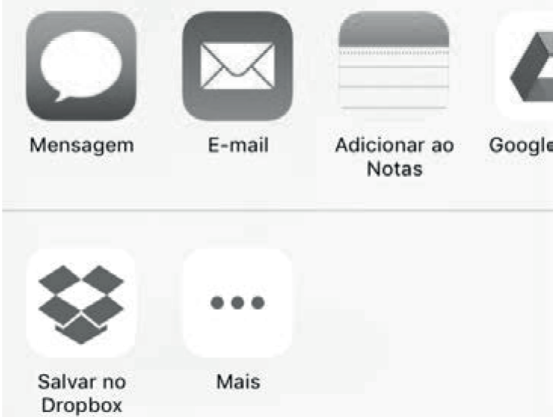

Fonte: Print de tela de Alexsandra Barbosa (16/10/2016). 


\section{A escrita e a narrativa no aplicativo WhatsApp}

Conforme Bakhtin (1997), em cada época de seu desenvolvimento, a língua é marcada por gêneros do discurso, estes gêneros podem ser orais e escritos. Levando em consideração a infinidade de gêneros - que dada à natureza humana é inesgotável - Bakhtin (1997) os divide em gêneros primários e gêneros secundários. Os primeiros são aqueles relacionados aos discursos do cotidiano, os mais informais. Já o segundo faz parte da escrita mais formal, como, os discursos científicos, os documentos oficiais etc. Podemos considerar que no diário online com WhatsApp o gênero seria primária, pois a linguagem ocorre de modo informal, imitando, muitas vezes, a oralidade na escrita do diarismo.

A literatura (secundária), conforme suas necessidades, busca na literatura popular (primária) gêneros do discurso falado-dialogado. No Whats App a escrita por vezes imita a linguagem oral por meio dos emoticons e das onomatopeias, figura de linguagem que imita o som, por exemplo, da risada (kkkk ou rsrs), de alívio (Ufa) ou de irritação (Grrr).

Estes códigos linguísticos propiciam maior interatividade nas narrativas do diário online. Os emoticons do App colaboram para expressar as emoçóes dos momentos vividos na pesquisa.

Figura 6 - Print de interação no Diário online com WhatsAppconversa escrita comigo

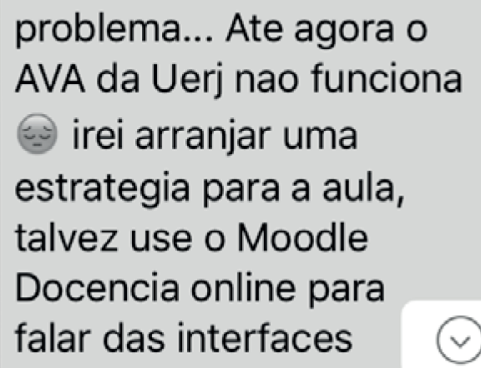

$01: 29 \mathrm{~W}$

Fonte: Print de tela de Alexsandra Barbosa (28/11/2016). 
No aplicativo a "construção de sentidos é multimodal, ou seja, os sentidos produzidos pelo modo convencional da escrita aliam-se aos modos orais, gestuais e visuais possíveis, transparecendo o sujeito de linguagem social, cultural, constituído historicamente" (BARBOSA, 2010, p. 12). O aplicativo permite diálogos textuais, por voz e a conversão da voz em texto. Assim, podemos utilizar tanto o recurso da conversa escrita quanto a narrativa por voz.

Para Bakhtin (1997) há um processo de formação no qual os gêneros primários se transformam em gêneros secundários, por exemplo, a linguagem utilizada no diário online, posteriormente, pode tornar-se uma linguagem própria de um artigo científico, a natureza do enunciado é diferente, mas a essência é a mesma, mudando a relação estabelecida com o leitor ou interlocutor.

Além de apresentarmos esses usos e possibilidades realizadas com o diário online por meio do WhatsApp, é interessante mencionarmos que nos diálogos consigo mesmo não há necessidade de conexão à internet, estando assim o aplicativo disponível a qualquer momento para a utilização de áudios e textos. A conexão com a internet somente será necessária ao compartilhar arquivos e links da web. Além disso, o aplicativo também está disponível para acesso pelo desktop.

\section{Conclusão}

Até chegarmos ao insight de utilizarmos o WhatsApp como diário online, muitas questôes pairaram sobre como potencializar uma escrita autoral e interativa. Uma vez imersos na cibercultura e fazendo uso de tecnologias móveis, quais dispositivos poderiam colaborar para uma pesquisa-formação na cibercultura com $A p p$-learning? De que modo estes se tornam interativos e hipertextuais, enriquecendo o processo formativo e autoral do pesquisador?

A mobilidade e a ubiquidade têm contribuído para borrar as fronteiras entre informação e aprendizagem, uma vez que, para 
além da informação disponível a toda hora, há troca, há relação, condição para a ampliação e ressignificação de sentidos inerente a todo processo de aprendizagem. No entanto, nossa experiência de pesquisadoras-praticantes na cibercultura tem nos mostrado que o uso de aplicativos e/ou redes sociais como dispositivos que intencionam ser espaçotempo de autoria, diálogo de saberes plurais e de multiletramentos, potencializam a formação de todos os praticantes envolvidos na pesquisa-formação (RIBEIRO, 2015; SANTOS, 2005, 2014).

É certo que muitas questôes ainda estão em curso, em mutaçóes e passíveis de ainda não terem sido respondidas até aqui. No entanto, a experiência de ter o WhatsApp como diário online tem mostrado que nós - enquanto praticantes culturais - podemos criar estratégias formativas, fazendo uso das interfaces digitais dos Apps para tornar ainda mais fecundo o processo de pesquisa-formação na cibercultura.

Acreditamos que a prática de diários de pesquisa online por meio de App-Learning potencializa a pesquisa e a formação, criando e compartilhando narrativas interativas e hipertextuais. Por esse motivo o grupo de Pesquisa Docência e Cibercultura (GPDOC - www.docenciaonline.pro.br) tem explorado o uso de aplicativos em suas pesquisas por perceber suas possibilidades de registro que desenvolvem e articulam uma escrita implicada e autoral.

\section{Referências}

ALVES, Nilda. Sobre movimentos das pesquisas nos/dos/com os cotidianos. In. OLIVEIRA, Inês Barbosa de; ALVES, Nilda (Org.). Pesquisa nos/dos/com os cotidianos das escolas. Petropolis: DP, 2008. p. 39-77.

AMANTE, Lúcia. Facebook e novas sociabilidades. Contributos da investigação. In: PORTO, Cristiane; SANTOS, Edméa (Org.). 
Facebook e educação: publicar, curtir, compartilhar. Campina Grande: Eduepb, 2014.

ARDOINO, Jacques. Abordagem multirreferencial (plural) das situaçôes educativas e formativas. In. BARBSOSA, J. (Org.). Multirreferencialidade nas ciências e na educaçáo. São Carlos: EdUFSCar, 1998. p.24-41.

ARDOINO, Jacques. Para uma pedagogia socialista. Brasília, DF: Plano, 2003.

BARBOSA, Joaquim Gonçalves; HESS, Remi. O diário de pesquisa: o estudante universitário e seu processo formativo. Brasilia: Liberlivro, 2010.

BARBIER, René. A pesquisa-ação. Tradução de Lucie Didio. Brasília: Plano, 2002.

BAKHTIN, Mikhail. Gêneros do Discurso. Estética da Criação Verbal, São Paulo: Martins Fontes, 1997. p. 277-326.

BRUNO, Adriana Rocha. Aprendizagem em ambientes virtuais: plasticidade na formação do adulto educador. Revista Ciências \& Cogniçáo, v. 15, p. 43-54, 2010. Disponível em: <http://pepsic. bvsalud.org/pdf/cc/v15n1/v15n1a05.pdf>. Acesso em: 20 jan. 2017.

CERTEAU, Michel de. A invençáo do cotidiano: artes de fazer. 22.ed. Tradução de Ephraim Ferreira Alves. Petrópolis, RJ: Vozes, 2014.

LÉVY. Pierre. As tecnologias da inteligencia: o futuro do pensamento na era da informática. Trad. Carlos Irineu da Costa. Rio de Janeiro: 24, 1993. 
MACEDO, Roberto Sidnei Compreender/mediar: o fundante da educação. Brasília: Liber livro, 2010.

MEDRADO, Benedito; SPINK, Mary Jane; MÉLLO, Ricardo Pimentel. Diários como atuantes em nossas pesquisas: narrativas ficcionais implicadas. In: SPINK, Mary Jane Paris et al. A produção de informaçáo na pesquisa social: compartilhando ferramentas. Rio de Janeiro: Centro Edelstein de Pesquisas Sociais, 2014. p. 273-274.

NASCIMENTO, Izabel. Cordel do Whatsapp (Esse tal de Zap Zap). YOUTUBE. 28/01/2016. Disponível em: <https://www. youtube.com/watch?v=5zdsnoBdFU0>. Acesso em: 20 jan. 2017.

RIBEIRO, Mayra Rodrigues Fernandes. A sala de aula no contexto da cibercultura: formação docente e discente em atos de currículo. 2015. 207f. Tese (Doutorado) - Faculdade de Educação, Universidade do Estado do Rio de Janeiro -, Rio de Janeiro, 2015.

SANTAELLA, Lúcia. Comunicação ubíqua: repercussóes na cultura e na educação. São Paulo: Paulos, 2013.

SANTAELLA, Lúcia. Prefácio. In: COUTO, Edvaldo; PORTO, Cristiane; SANTOS, Edméa (Org.). App-learning: experiências de pesquisa e formação. Salvador: Edufba, 2016. p. 7-10.

SANTOS, Edméa. Pesquisa-formação na cibercultura. Portugal: Whitebooks, 2014.

SILVA, Marco. Pedagogia do Parangolé. EAD ONLINE.

Disponível em: <http://www.serfran.pro.br/interatividade.htm>. Acesso em: 20 abr. 2017. 
VIEIRA, Simone Bastos. Indexação automática e manual: revisão de literatura. Ciência da Informação, Brasília, v. 17, n. 1, p. 43-57, jan./jun. 1988. Disponível em: <http:// repositorio.unb.br/bitstream/10482/12901/1/ARTIGO_ IndexacaoAutomaticaManual.pdf>. Acesso em: 20 abr. 2017.

ZABALZA, Miguel Ángel. Diários de aula: contributo para o estudo dos dilemas práticos dos professores. Tradução José Augusto Pacheco. Portugal: Porto, 1994. 


\title{
A WEB 2.0 E OS SOFTWARE SOCIAIS: OUTROS ESPAÇOSTEMPOS MULTIRREFERENNCIAS DE FORMAÇÃO NA INICIAÇÃO À DOCÊNCIA
}

\author{
Simone Lucena - UFS \\ Arlene Araújo Domingues Oliveira - UFS \\ Gilson Pereira dos Santos Júnior - UFS
}

Antes de ensinar o que quer que seja a alguém, é preciso, no minimo, conhecer este alguém. Nos dias de hoje, quem se candidata à escola, ao ensino básico $e$ a universidade?

Michel Serres (2013)

\section{Introdução}

Em 2013, foi lançada no Brasil a obra Polergarzinha do filósofo francês Michel Serres que utilizou esta denominação para se referir aos adolescentes que habitam o mundo virtual e utilizam os dedos polegares para enviar mensagens dos seus smartphones. No referido livro, Serres mostra quem são estes jovens, o que desejam, como aprendem, constroem conhecimentos e valores no mundo virtual. $\mathrm{O}$ autor mostra também como as instituiçóes educacionais e a "polergarzinha" habitam mundos diferentes, pois enquanto o professor "verbalizava o escrito, uma página matriz" (SERRES, 2013, p. 44) a polegarzinha já tem 
[...] o tal saber que se anuncia. Inteiro. À disposição. Na mão. Acessível pela internet, Wikipédia, celular, em inúmeros sites. Explicado, documentado, ilustrado, sem maior número de erros do que nas melhores enciclopédias. (SERRES, 2013, p. 45).

Serres, assim como Freire e Guimarães (2003), Babin e Kouloumdjian (1989), Pretto (1996), entre outros autores, nos chamam a atenção para o descompasso e, talvez, até já certo abismo existente entre a escola e os alunos. No livro Sobre Educação (Diálogos) vol.2 - Paulo Freire e Sérgio Guimarães (2003) debatem temas relacionados ao uso dos meios de comunicação na escola. Para Freire (2003, p. 36), a escola não tem que brigar com a presença dos meios de comunicação, pois as

[...] presenças que vêm surgindo em função do desenvolvimento da ciência e da tecnologia, e que, no campo da comunicação, a superam de longe, de muito longe! Aliás se tu comparas a escola com esses meios que vêm emergindo no campo da comunicação com profunda dinâmica [...] podes observar como a escola é estática, perto deles!

Babin e Kouloumdjian (1989, p. 7), referindo-se na década de 1980 do século XX aos jovens da geração do audiovisual e do computador, diziam que "eles estão em outra". Em outra forma de ser, de pensar, de interagir e de aprender com o outro e com o mundo. Para estes autores será preciso ainda muito tempo para que efetivamente as tecnologias audiovisuais sejam completamente inseridas no processo de aprendizagem, pois “os hábitos culturais e as instituições que sustentam a sensibilidade de uma população avançam menos rapidamente que as descobertas técnicas ou os imperativos econômicos" (BABIN; KOULOUMDJIAN, 1989, p. 169). 
Por conta destes imperativos econômicos, muitas escolas públicas no Brasil no final do século $\mathrm{XX}^{1}$ foram equipadas com tecnologias de informação e comunicação (TIC) criando salas como "laboratório de informática" onde alguns poucos professores e alunos utilizavam as tecnologias, na maioria das vezes, de forma instrumental como mais um recurso didático (PRETTO, 1996), subutilizando todo o potencial criativo, interativo e colaborativo que as TIC podem proporcionar. Para superar a perspectiva do uso das tecnologias como instrumentalidade, Pretto (1996, p. 115) sugere a perspectiva do fundamento, pois desta forma as TIC "passam a fazer parte da escola como um elemento carregado de conteúdo [...], como representante (talvez principal!) de uma nova forma de pensar e sentir, que começa a se construir”.

As (r)evoluções científicas e tecnológicas presentes na sociedade contemporânea colocam as pessoas, principalmente os jovens, potencialmente em contato com tecnologias e redes virtuais que possibilitam outras lógicas de ser e estar no mundo. Estes jovens são de uma geração que nasceu num mundo onde as tecnologias móveis, as culturas digitais e as relaçôes sociais potencializadas pela Web 2.0 se expandiram consideravelmente, criando outros espaçostempos (LUCENA; OLIVEIRA, 2017) ubíquos e multirreferenciais onde a construção do saber e o seu compartilhamento ocorrem de forma horizontal, sem a verticalidade do falar/ditar do professor em sala de aula.

A rede conexão internet foi desenvolvida no final do século XX e desde então passou por diferentes transformações. No início havia apenas páginas estáticas, sem os hipertextos e a interatividade que hoje encontramos em quase todos os sites da Web. Nessa primeira fase da internet, conhecida como Web 1.0, as informaçóes

1 Em 1995, o Ministério da Educação (MEC) iniciou o Programa TV Escola que entre outras ações instalou inicialmente a televisão, o videocassete e antena parabólica para as escolas. Em 1997, foi lançado o Programa Nacional de Informática na Educação (ProInfo) cujo um dos objetivo era instalar computadores nas escolas públicas do país. 
eram recebidas no sentido broadcasting. O desenvolvimento da Web 2.0 mudou completamente esta forma de produzir e compartilhar as informaçóes, pois cada sujeito que interage na rede é potencialmente um produtor de conteúdos que são compartilhados em sites de redes sociais ou em blogs, utilizando diferentes linguagens texto, imagem, vídeo e áudio.

Inserir as culturas digitais e as interfaces da Web 2.0, seja na educação básica ou superior, requer (re)pensar o currículo dos cursos de formação inicial e continuada dos professores. Apesar de muitas instituiçóes de ensino superior (IES) realizar reformulaçóes nos currículos de formação, ainda persiste a dicotomia entre as disciplinas de conteúdos teóricos específicos, ou de fundamentos, e as disciplinas de conteúdos didáticos-pedagógicos de caráter práticos.

Paralela a esta discussão, Imbernón (2016) nos chama a atenção para a necessidade de mudanças nas modalidades e estratégias utilizadas nos cursos de formação dos professores. Para este autor ,é preciso elevar a qualidade da formação, pois "o que se diz é tão importante quanto a maneira como se diz e se trabalha. $\mathrm{O}$ método de formação será tão importante quanto seu conteúdo" (IMBERNÓN, 2016, p. 165).

Nesse sentido, Imbernón (2016) propõe a construção de uma metodologia formativa nos cursos de formação de professores. Esta metodologia passaria pela efetiva participação em situaçóes problemas existente nas escolas, cujas discussóes envolveriam todos os professores para além das análises teóricas da situação, pois o mais importante seria modificar a realidade por meio de uma mudança da prática.

Vamos colocar o professorado não tanto em uma atitude na qual seja ensinado, mas em situaçóes de aprendizagem. Para tanto, a formação, mais que ensinar ou formar deveria criar situaçóes e espaços de reflexão e formação; mudar a metodologia. 
Tudo isso supóe uma mudança [...] que obriga a desenvolver na formação docente uma nova metodologia de trabalho, que consiste em aprender e observar os outros, a permitir que o observem e a observar a si mesmo; em criar espaços de aprendizagem mútua, trocando experiências. (IMBERNÓN, 2016, p. 168).

Possibilitar mudanças na formação e na prática docente foi sempre um dos objetivos do Programa Institucional de Bolsas de Iniciação à Docência (PIBID) no curso de Pedagogia da Universidade Federal de Sergipe - Campus Prof. Alberto Carvalho. O subprojeto do Pibid/Pedagogia intitulado "Leitura, diversidade e ludicidade na formação docente: desafios para a educação" foi iniciado em 2014. Este projeto está dividido em quatro eixos, sendo um deles o de Formação de Professores que conta atualmente com 18 bolsistas de iniciaçáo à docência (ID) e três professoras supervisoras, atuando em duas escolas públicas de ensino fundamental.

No Pibid, as interfaces da Web 2.0 como Blog, Google Drive e Facebook foram utilizadas durante a formação dos bolsistas e supervisoras. O software social WhatsApp Messenger foi utilizado como espaço de comunicação entre todos os integrantes do eixo para trocas de informaçóes sobre as atividades desenvolvidas, bem como para divulgação de notícias e compartilhamento de imagens, áudio e vídeos.

Podemos dizer que a principal mudança proporcionada pela Web 2.0 em relação à fase anterior da internet foi possibilitar a interatividade entre as pessoas tornando-as sujeitos produtores e divulgadores de culturas e conhecimentos. Por esta razão, desde o início das atividades formativas no Pibid/Pedagogia, as TIC foram utilizadas como fundamento, na perspectiva de Pretto (1996), buscando discutir, utilizar e inserir as bolsistas ID e supervisoras como produtoras de conteúdos nas interfaces da Web 2.0 e software sociais. 


\section{Web 2.0 e os software sociais}

As transformaçóes socioculturais advindas do desenvolvimento de software e interfaces da denominada Web 2.0 potencializaram que cada cidadão comum, sujeito interagente (PRIMO, 2007) possa tornar-se, na rede, um a(u)tor (LUCENA, 2012), um coautor de saberes, culturas e conhecimentos compartilhados incomensuradamente. Para Andrade e Neves (2011, p. 25), a Web 2.0 "constitui a face mais visível e inovadora do ciberespaço e do cibertempo, na forma de blogs, wikis, RSS etc".

De acordo com Andrade e Neves (2011), a Web 2.0 centra suas prioridades em três principais características:

1 - O software social ou software operativo são instalados em servidores de empresas ou entidades que disponibilizam seu acesso público pela internet. Para utilizar estes software não é mais necessários entalá-los em computadores fixos, pois eles são web applications ou apps que podem ser acessados em qualquer dispositivo digital móvel conectado a internet;

2 - A produção de conteúdos ampliou de forma considerável com a Web 2.0, pois, conforme mencionado anteriormente, o cidadão comum passou a ser um potencial produtor de conteúdos nos blogs e demais ambientes dialógicos, hipertextuais disponíveis na rede. Para tanto, a escrita ganhou a denominação de post que podem também receber comentários (comments) de outros interlocutores. Nesta nova era da reading-writing internet é possível criar sinalizadores de páginas nos social bookmarking e ainda criar tag ou palavras-chave associadas a uma informação. Atualmente os sites de redes sociais, a exemplo do Twitter, Facebook, Instagram e Myspace, utilizam hashtag ${ }^{2}$ composto por expressóes com pala-

2 O dicionário Oxford (2014) define como: hashtag n. (nas mídias sociais de sites e aplicativo) uma palavra ou frase após uma cerquilha usada para identificar mensagens relacionadas a um tópico específico; [também] o próprio símbolo da cerquilha quando utilizado desta maneira. 
vras-chave antecedidas do símbolo (\#). Numa rede social, o uso de hashtag cria links que tornan a expressão indexada nos mecanismos de busca;

3 - As comunidades virtuais passaram a ter novos espaços de interação nas redes digitais sociais que ganharam mobilidade e ubiquidade com a disseminação dos apps nos dispositivos móveis, principalmente nos smatphones.

Segundo Lucena e Oliveira (2017, p. 35),

o desenvolvimento tanto dos Apps quanto dos softwares sociais iniciaram a partir dos anos 2000 e ganhou popularidade entre os utilizadores dos smartphones e demais dispositivos móveis. Atualmente existem Apps para várias funções, tais como: previsão do tempo, jogos, mapas, GPS, emissão de bilhetes de viagem, compra de ingressos, cuidados com a saúde, habilidades esportivas, moda, aplicaçóes financeiras, comunicação e educação.

Atualmente um dos apps mais utilizados é o WhatsApp Messenger, que é uma aplicação gratuita e multiplataforma (Android, iPhone, Mac, Windows PC e Windows Phone) para troca de mensagens entre os contatos por meio de uma interface gráfica simples e usual. Nesta aplicação, a forma de comunicação é assíncrona e a confidencialidade dos dados é garantida por uma criptografia ponta a ponta (WHATSAPP, 2017). Além da funcionalidade de mensageiro, o WhatsApp permite a criaçáo de grupos de contatos para troca de mensagem, a realização de chamadas de voz, bem como o compartilhamento de arquivos de textos, áudios, fotos e vídeos.

O funcionamento desta aplicação depende de uma conexão ativa para acesso a internet, seja por uma banda larga ou por um pacote de dados com tecnologia $2 \mathrm{G}, 3 \mathrm{G}$ ou $4 \mathrm{G}$ ofertado pela operadora de telefonia. Hoje, no Brasil, as companhias telefônicas, a exemplo da TIM, da Vivo e da Claro, acompanham a demanda de 
transmissão de dados gerada pelo WhatsApp e ofertam, inclusive, serviços exclusivos ou com vantagens para este propósito.

Silva e Vilhegas (2015) apontam a eficiência na interação entre a aplicação e a lista de contatos; a usabilidade da gerência do status do usuário, da criação de grupos e do bloqueio e desbloqueio de contatos; além da padronização de telas e botóes que facilitam o aprendizado do uso da aplicação como alguns dos pontos positivos do WhatsApp na perspectiva da Interação Humano-Computador (IHC).

A portabilidade para utilização em diferentes dispositivos móveis, a gratuidade do serviço, a usabilidade e a simplicidade da interface promoveram o sucesso e o crescimento exponencial na adoção do WhatsApp como aplicaçáo para troca de mensagens. Hoje, ela possui 1,2 bilhão de usuários no mundo, sendo $120 \mathrm{mi}$ lhôes residentes no Brasil, superando a marca de 1 bilhão de usuários ativos no Facebook (OLHAR DIGITAL, 2017).

A abrangência de comunicação e o número de usuários conectados ao WhatsApp permite-nos encarar tal aplicação como uma inovação disruptiva, que colocou em desuso a troca de mensagem via Short Message Service (SMS) e, por vezes, substitui a principal função do celular, a ligação telefônica. Desta forma, conforme ressalta Fontana (2015, p. 291) "as ferramentas de comunicação, como WhatsApp, promove o contato cada vez mais eficaz fazendo parte de uma reestruturação da comunicação".

A educação não pode se abster, fechar os olhos ou tentar impedir que as tecnologias adentrem o ambiente escolar, pois, segundo Kelly (2017), o mundo digital em que vivemos é regido por doze forças inevitáveis e indissociáveis que impulsionarão os avanços tecnológicos pelos próximos trinta anos. Para o autor, com "as mensagens instantâneas eram inevitáveis; tuitar a cada 5 minutos" (KELLY, 2017). Assim, entendemos que o surgimento de aplicaçôes nos moldes do WhatsApp era inevitável, mas uma sociedade integralmente conectada a este serviço, não. E, se o aluno optou e está acostumado a comunicar-se e relacionar-se por meio desta pla- 
taforma, os docentes podem utilizar tal interface nas suas práticas pedagógicas e inserir este novo meio de comunicação no processo de aprendizagem.

Dessa forma, o WhatsApp pode se tornar mais uma alternativa de espaçotempo multirreferencial de comunicação e aprendizagem, possibilitando que professores e alunos possam interagir em qualquer lugar e a qualquer momento. Essa ressignificação do uso do mensageiro como um dispositivo educacional "favorece o processo de ensino e aprendizagem, promove a imersão neste contexto digital e tecnológico, além de aproximar professores e alunos" (FONTANA, 2015, p. 304). Entretanto, é importante ressaltar que o professor, ao optar por uma comunicação via este aplicativo, precisa estar certo que a interação será no sentido todos-todos e náo mais no sentido um-todos ele era o protagonista. Acreditamos que a principal contribuição que o WhatsApp pode possibilitar para a educação é fazer com que professores e alunos possam cocriar saberes e culturas.

Porém, para inovar na educação, não basta se apropriar da tecnologia e empregá-la em sala de aula. O docente precisa repensar e adaptar suas práticas, observar os pontos fortes e limitaçóes da tecnologia e tomar as devidas precauçôes durante o uso. Neste sentido, Fontana (2015) apontou que o uso do WhatsApp possibilitou a "aquele aluno que não participa com opiniōes no ensino presencial, neste modelo de atividade se coloca, se mostra, participa" (FONTANA, 2015, p. 306), mas para atingir tal resultado "é fundamental a conscientização da etiqueta e respeito durante a interação. Trabalhar com os alunos a ideia de que discordar é ter outras opinióes, saudáveis e enriquecedoras" (FONTANA, 2015, p. 305).

Pereira e Araújo (2015, p. 2) propóem o uso do WhatsApp na educação como "um espaço para a livre expressão dos alunos, desenvolvendo sua criticidade e possibilitando a prática do multiletramento, a partir das multimodalidades e multisemioses disponíveis no aplicativo". 


\section{Espaçostempos multirreferências no Pibid}

Grande é o desafio das instituições destinadas à formação de profissionais da educação, pois a sociedade atual, por meio do desenvolvimento científico e tecnológico, tem colocado a necessidade de mudanças para os docentes, que necessitam buscar saberes para interagir com os seus alunos. Segundo Rojo (2012), além do letramento convencional como livros, jornais, revistas, entre outros, faz-se necessário o multiletramento, a exemplo da internet, dos e-mails e dos blogs, os alunos possam produzir e refletir o porquê e o para que estejam produzindo as atividades dos seus professores.

Para Rojo (2012), as linguagens audiovisuais e imagéticas são atrativas para os alunos porque são contemporâneas e fazem parte da sua geração, logo, eles estão acostumados a utilizá-las e se ainda não as utilizam, terão oportunidade de aprendê-las junto com seus colegas, em um processo de troca de conhecimentos, de criatividade e, principalmente, de aprendizagem de conteúdos pedagógicos.

No Pibid foi possível produzir algumas atividades da pedagogia do multiletramento, sugeridas por Rojo (2012). O multiletramento é um conjunto de açôes interativas, colaborativas, em que há quebra de paradigma e as produçôes são disponibilizadas na rede (Web), ou melhor, como a autora mesmo define, nas "nuvens". Nesta perspectiva, todas as bolsistas ID e supervisoras do Pibid participaram de um processo formativo, utilizando os multiletramentos.

Inicialmente foi realizado um curso de extensão na modalidade semipresencial, utilizando a plataforma Moodle $e^{3}$ intitulado "Formação do Professor e Uso das Tecnologias". Este curso foi dividido em 4 etapas: (i) A Geração Net e a Formação de Professo-

3 O Moodle é um ambiente on-line de aprendizagem, gratuito, customizável, que permite a criaçáo de cursos dinâmicos, a participação de fórum e a execução de atividades colaborativas a qualquer momento, em qualquer lugar. Site: https://moodle.org/ 
res; (ii) Culturas Digitais e Educação; (iii) Práticas Pedagógicas na Cibercultura; e (iv) Produzir e Publicar. O Moodle foi utilizado por ser "um ambiente online de aprendizagem que agrega e estrutura uma comunidade mundial de produtores de conteúdos abertos" (SANTOS, 2010).

Assim, esta plataforma reúne sujeitos do mundo todo que desenvolvem e compartilham diversas aprendizagens. No caso particular do curso de extensão, o Moodle proporcionou as primeiras interaçóes entre os participantes do curso por meio dos fóruns de discussão, diários e wiki. Entretanto por conta de problemas técnicos com o servidor onde estava instalado o Moodle, que frequentemente impossibilitava o acesso ao ambiente virtual, foi preciso buscar outras interfaces na Web que pudessem manter a interatividade entre os participantes dos grupos.

A pluralidade dos ambientes e interfaces existentes na Web nos faz acreditar que esta rede é cada vez mais um espaçotempo multirreferencial de autoria e criação com infinitas possibilidades, pois aprender na/com as redes não é uma aprendizagem instrumental, mas sim, uma aprendizagem política, social, ética e cultural. A abordagem multirreferencial nas ciências humanas, segundo Ardoino (1998, p. 24)

\begin{abstract}
[...] propó-se a uma leitura plural de seus objetos (práticos ou teóricos), sob diferentes pontos de vistas, que implicam tanto visóes específicas, quanto linguagens apropriadas às descriçốes exigidas, em função de sistemas de referências distintos, considerados, reconhecidos explicitamente como não-redutíveis uns aos outros, ou seja, heterogêneos.
\end{abstract}

Dentro desta perspectiva, Ardoino (1998) coloca que a realização de projetos desenvolvidos em conjunto criam vínculos sociais entre seus integrantes, fazendo com que estes atores-agentes tornem-se protagonistas e se reconheçam no projeto. Nesse sentido, 
as açôes formativas desenvolvidas no Pibid tiveram este caráter de tornar os integrantes do eixo Formação de professores atores-agentes com autoria e autonomia para pensar, criar, cocriar atividades, conteúdos, informações, conhecimentos. Para tantos, diferentes interfaces on-line e gratuitas foram utilizadas.

Para a realização de escrita colaborativa, utilizamos o Google Drive. Esta interface disponibilizada pela multinacional Google Inc. permite o armazenamento nas nuvens de "todos os seus arquivos, sempre que você precisar” (GOOGLE DRIVE, 2017). O Google Drive disponibiliza 15 gigabytes de armazenamento on-line gratuito para que o usuário guarde suas fotos, textos, vídeos, áudios, desenhos e outros dados. Além do armazenamento, a plataforma permite o compartilhamento dos arquivos, bem como a visualização e a edição destes, em qualquer lugar, por meio da integração com outras aplicaçóes da própria empresa, a exemplo do Google Docs para texto, Google Sheets para planilhas, o Google Slides para apresentaçóes digitais e o Google Sites para criação de páginas web, ou aplicações de terceiros, desenvolvidas a partir da biblioteca do Google.

Dentre as inúmeras possibilidades desta plataforma é importante ressaltar a facilidade de uso do Google Drive nos dispositivos móveis, em especial, nos aparelhos que possuem o sistema operacional Android, criado pela própria Google Inc.

Assim, a partir das interfaces disponibilizadas pela plataforma do Google, os bolsistas utilizaram também o Google Slides na criação de apresentaçóes para os eventos acadêmicos, o Google Docs na construçáo dos relatórios de atividades e o Google Drive para o compartilhamento de textos/apostilas com conteúdo pertinente ao eixo. Esta prática transpôs as barreiras de tempo e espaço, permitindo a criação e cocriação das atividades entre bolsistas que moravam em locais geograficamente distantes.

Além do Moodle e das aplicaçóes da plataforma do Google, os participantes do projeto utilizaram a rede social Facebook e o mensageiro WhatsApp Messenger. No Facebook foi criado um grupo para 
permitir a interação entre as bolsistas e as supervisoras e possibilitar o compartilhamento de informaçóes por meio da postagem de notícias, textos, imagens e vídeos, visando o crescimento formativo dos participantes.

Para ampliar ainda mais a interação, os bolsistas criaram também um grupo no WhatsApp Messenger, visto que todos os integrantes do projeto possuíam celulares do tipo smartphones e demonstraram afinidade com esta aplicação. Além disso, muitos bolsistas moravam em localidades fora do município sede onde está situado o Campus da Universidade Federal de Sergipe (UFS) e nestes locais praticamente não existe conexão a internet, o que dificulta o acesso à maioria dos sites na rede. Entretanto, como para acessar o WhatsApp não é preciso ter uma conexão com alta velocidade, é possível utilizá-lo a todo o instante para compartilhar informações em diferentes formatos. A partir da criação do grupo do WhatsApp, muito mais imagens, vídeos e mensagens sobre as atividades realizadas pelas bolsistas passaram a ser trocadas.

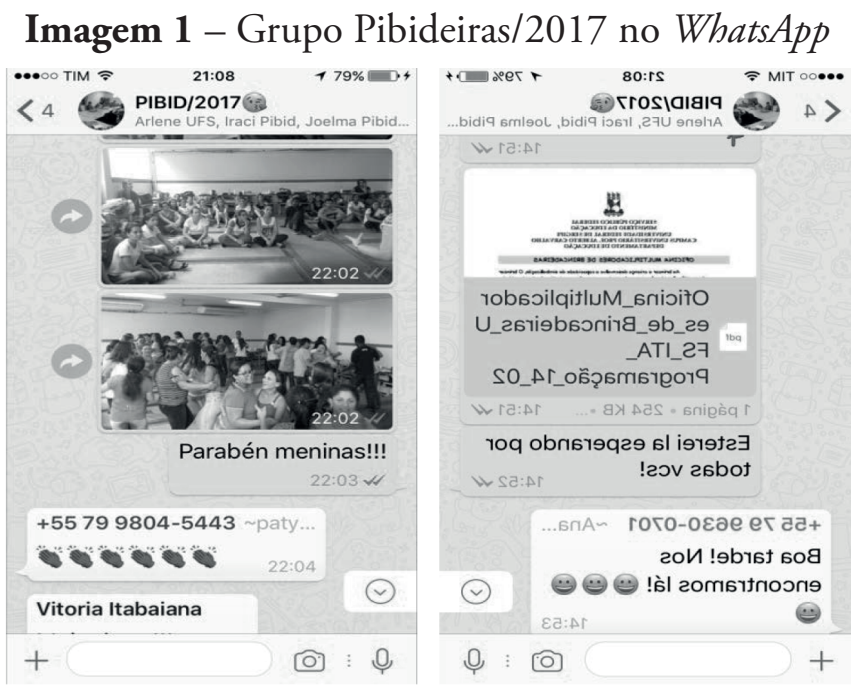

Fonte: Arquivo dos autores do texto. 
Observamos que no grupo do WhatsApp Messenger houve um aumento na frequência de interação maior aproximação entre todos os integrantes do eixo Formação de Professores, pois apesar de estarem geograficamente distantes, ou realizando oficinas do Pibid em diferentes escolas, eles mantinham contato intenso. Percebemos assim que grupo no WhatsApp propicio aquilo que Santaella (2016) chamou de u-learning ou aprendizagem ubíqua. Uma aprendizagem que acontece a partir do uso de dispositivos móveis conectados em rede. Para esta autora, o desenvolvimento dos apps tem proporcionado ainda uma app-learning, ou seja, uma aprendizagem que ocorre a partir da utilização de aplicativos "dos mais diferentes tipos e das mais diferentes finalidades à disposição de educadores e educadoras" (SANTAELLA, 2016, p. 10) presentes nos dispositivos móveis.

\section{Conclusáo}

O século XXI é marcado pela intensificação do uso das TIC conectadas a internet em todos os setores da sociedade. $\mathrm{O}$ cidadão deste novo milênio passou a utilizar as interfaces da Web 2.0 e os software sociais para ampliar a comunicação, interagindo com pessoas de diferentes regióes geograficamente distantes. Os jovens são com certeza os que mais utilizam as tecnologias digitais móveis para fins variados jogar, se comunicar, estudar, ouvir músicas, assistir vídeos e, sobretudo, para produzir, publicar e compartilhar seus conteúdos.

Apesar de muitos estudos e pesquisas (FREIRE; GUIMARÁES (2003), BABIN; KOULOUMDJIAN (1989), PRETTO (1996), SERRES (2013), LUCENA (2012; 2014), BONILLA (2005), SANTAELLA (2016), SANTOS (2014) etc.) já terem apontado as possibilidades das TIC para a educação, ainda há poucas experiências com a utilização destas tecnologias na escola. Muitos são os motivos que dificultam a inserção das TIC no processo 
educacional. Dentre estes motivos, podemos ressaltar a falta de políticas públicas para inserção das tecnologias nas instituiçóes educacionais que seja acompanhada de formação continuada de professores e do seu fortalecimento para que possam pensar, criar coletivamente possibilidades de trabalhar com as TIC no cotidiano escolar.

Outro ponto que impossibilita o uso das TIC na educação é a inserção das tecnologias no currículo dos cursos das licenciaturas. Apesar de muitas IES terem reformulados seus currículos ainda há uma dicotomia entre as disciplinas de conteúdo específico e as de conteúdos didáticos. Discutir TIC nas licenciaturas acaba se limitando a uma disciplina que nem sempre é eletiva para alguns cursos. Desta forma, muitos docentes concluem o curso universitário sem ter vivenciado experiências, discutido possibilidades ou criado projetos que oportunizem o uso das TIC na educação.

O Pibid é um programa criado em 2007 voltado para a formação inicial (bolsistas ID) e continuada (supervisores) de professores sob a responsabilidade da Capes. Atualmente estáo em vigor os projetos das IES aprovados no Edital no 061/2013. No curso de Pedagogia da UFS - Campus Prof. Alberto Carvalho localizado na cidade de Itabaiana-SE, o Pibid tem sido trabalhado numa perspectiva de proporcionar aos licenciandos aproximaçóes entre os espaços de formação e do trabalho nas escolas. As reunióes presenciais que ocorrem semanalmente contam com a participaçáo dos bolsistas ID, professores supervisores e coordenadora de área do Pibid/ Pedagogia. Nestas reunióes, as discussóes perpassam pelos desafios e dilemas docentes, bem como os problemas existentes nas escolas onde as atividades do Pibid acontecem.

Para ampliar os espaçostempos de estudos e debates, contamos com a utilização de interfaces da Web 2.0 como blog e Facebook, também o aplicativo WhatsApp. Consideramos estas interfaces e app como espaçostempos multirreferencias que possibilitam múltiplas e diferentes oportunidades dos sujeitos interagentes do Pibid serem a(u)tores, produtores de saberes, culturas e conhecimentos. 


\section{Referências}

ARDOINO. J. Abordagem multirreferencial (plural) das situaçóes educativas e formativas. In: BARBOSA, J.G. (Org.). Multirreferencialidade nas ciências e na educaçáo. São Carlos: EDUFSCar, 1998.

ANDRADE, P. de; NEVES, J.P. Apresentação. Revista de comunicaçáo e Linguagem. Dossiê Geneologias da Web 2.0. Lisboa: Relógio d’Água, n. 42, p. 25-27, 2001.

\section{BABIN, P.; KOULOUMDJIAN, M.J. Os novos modos de} compreender: a geração do audiovisual e do computador. São Paulo: Paulinas, 1989.

BONILLA, M.H. Escola Aprendente: para além da sociedade da informação. Rio de Janeiro: Quartet, 2005.

FONTANA, L.A.M. Whatsapp na educaçáo: criar, construir e compartilhar. Sobre educação e tecnologia: processos e aprendizagem. São Paulo: Pimenta Cultura, 2015. Disponível em: <https://books.google.com. br/books?id=f-ufCwAAQBAJ\&lpg=PP1\&hl=ptBR\&pg=PP1\# $v=$ onepage\&q\&f=false $>$. Acesso em: 2 jul. 2017.

FREIRE, P.; GUIMARÃES, S. Sobre Educação: Diálogos. V.2. São Paulo: Paz e Terra, 2003.

GOOGLE DRIVER. Google driver. Disponível em: <https:// www.google.com/drive/>. Acesso em: 2 jul. 2017.

IMBERNÓN, F. Qualidade do ensino e formação do professor: uma mudança necessária. São Paulo: Cortez, 2016. 
KELLY, Kevin. Inevitável: as 12 forças tecnológicas que mudarão o nosso mundo. Casa Educação, 2017.

LUCENA, S.; OLIVEIRA, A.A.D. Os softwares sociais e a web 2.0 como espaços multirreferencias em programa de iniciaçáo à docência. Laplage em Revista. Sorocaba, v. 3, n. 2, p. 34-46, maio/ago. 2017.

LUCENA, S. Culturas digitais e tecnologias móveis na educação. Educar em Revista, Curitiba, Brasil, n.59 p.277-290, jan./mar. 2016.

\section{LUCENA, S. (Org.). Cultura Digital, Jogos Eletrônicos e}

Educação. Salvador: Edufba, 2014.

LUCENA, S. Educaçáo e TV digital: situação e perspectivas. Maceió: Edufal, 2012

\section{OLHAR DIGITAL. Whatsapp revela número de usuários} no Brasil. Disponível em: <https://olhardigital.com.br/noticia/ whatsapp-revela-numero-de-usuarios-no-brasil/68604>. Acesso em: 2 jul. 2017.

WHATSAPP. Whatsapp. Disponível em: <https://www. whatsapp.com>. Acesso em: 2 jul. 2017.

PEREIRA, A.P.; ARAÚJO, A.R. PIBID online: Uso do WhatsApp como ferramenta didática. Anais do $\mathrm{V}$ Encontro de Iniciação à Docência da UFPB (ENID). Realize, Paraíba, v. 1, 2015.

PRETTO, N. de L. Uma escola sem/com futuro: educação e multimídia. São Paulo: Papirus, 1996.

PRIMO, A. Interação mediada por computador: comunicação, cibercultura, cognição. Porto Alegre: Sulinas, 2007. 
ROJO, R. Pedagogia dos multiletramentos: diversidade cultural e de linguagens na escola. In: ROJO, R.; MOURA, E. (Org.). Multiletramentos na escola. São Paulo: Párabola, 2012.

SANTAELLA, L. Prefácio: App-learning e a imaginação criativa a serviço da educação. COUTO, E.; PORTO, C.; SANTOS, E. (Org.). App-learning: experiências de pesquisa e formação. Salvador: Edufba, 2016.

SANTOS, E.O. A Informática na Educação antes e depois da Web 2.0: relatos de uma docente-pesquisadora. In: RANGEL, M.; FREIRE, W. (Org.). Ensino-Aprendizagem e Comunicaçáo. Rio de Janeiro: Wak, 2010.

SANTOS, E. (Org.). Diário online: dispositivo multirreferencial de pesquisa formação na cibercultura. Santo Tirso-Portugal: Whitebooks, 2014.

SERRES, M. Polegarzinha. Rio de Janeiro: Bertrand Brasil, 2013.

SILVA, Andrey; VILHEGAS, Viviani. IHC em dispositivos móveis-análise do aplicativo whatsapp. In: Anais do ETIC Encontro de Iniciação Científica, v. 9, n. 9, 2015. 


\title{
CIÊNCIA COM LEVEZA: O WHATSAPP COMO ARTEFATO PEDAGÓGICO NA DISCIPLINA METODOLOGIA DO TRABALHO CIENTÍFICO
}

\author{
Rosemary Lacerda Ramos - Unijorge
}

\section{Introdução}

São inadiáveis as mudanças provocadas no cenário educacional nesta sociedade contemporânea ou líquida, marcada, influenciada e impactada pela convergência da tecnologia, da ubiquidade dos meios e do hibridismo dos conteúdos das mídias, quer digitais, sociais e as novas aplicaçóes que se fazem cada vez mais frequentes e presentes em processos educativos formais ou informais, inclusive nas instituiçôes de ensino superior, alterando significativamente nos mecanismos de ensino e aprendizagem das pessoas (LÈVY, 1999; SANTAELLA, 2013).

Cada vez mais, nos projetos pedagógicos dos cursos de graduação e pós-graduação, estabelecem como princípio para o trabalho pedagógico a integração com tecnologias digitais, além da articulação teoria-prática e adoção de metodologias ativas no processo ensino e aprendizagem. Mas a mudança efetiva na arquitetura das aulas universitárias - especialmente nos cursos lato sensu - ainda é lenta e desafiadora, de problemas de infraestrutura adequada até o preparo do docente para adequar-se aos novos paradigmas de produção, consolidação e disseminação do conhecimento. 
Alguns componentes curriculares, em especial, caracterizamse por manter uma estrutura tradicional, sendo comum o uso de aulas eminentemente expositivas, dissociação teoria prática e baixa interação com a tecnologia, a exemplo da disciplina Metodologia do Trabalho Científico. Ora, tal componente, por sua própria natureza e objetivo central - preparar o estudante para sua iniciaçáo científica -, deveria ser uma das primeiras a agregar as contribuiçóes das tecnologias digitais em sua arquitetura de aula, assegurando aproximação do estudante ao universo da produção científica em um cenário marcado pela mobilidade, ubiquidade e colaboração.

Compreende-se que a adoção de artefatos digitais, quer redes, mídias sociais, a exemplo dos grupos do Facebook, Twitter e recentemente WhatsApp contribuem com o desenvolvimento de competências e habilidades necessárias à produção do trabalho científico, favorecem a consolidação de aprendizagens significativas para a iniciação científica dos estudantes, além de envolvê-los, reduzindo a rejeição dos estudantes a este componente curricular compreendido como um "mal necessário" pelos mesmos, reduzindo-se a suporte para elaboração do TCC. Em tal cenário, questiona-se: quais as possibilidades pedagógicas do uso do WhatsApp como artefato lúdico digital para o ensino de Métodos e Técnicas do Trabalho Científico?

O presente artigo tem como objetivo e eixo central estabelecer reflexôes sobre a contribuição do uso da plataforma comunicacional WhatsApp como Artefato Lúdico e Digital mediador do processo de ensino e aprendizagem. A experiência desenvolvida se estrutura conceitualmente nos princípios da Aprendizagem Colaborativa, do Ensino Híbrido, da Aprendizagem Móvel e das Metodologias Ativas. Para tal, fez-se uma pesquisa ação (THIOLLENT, 2017), por meio de uma experiência pedagógica durante a disciplina Métodos e Técnicas do Trabalho Científico, em uma turma de Pós-graduação Lato Sensu, de uma universidade baiana.

A experiência faz parte de uma proposta educativa mais ampla denominada "Ciência com Leveza" cujo objetivo é a adoção de 
novas abordagens metodológicas no ensino de Métodos e Técnicas do Trabalho Científico, bem como o desenvolvimento de uma relação mais positiva dos estudantes com tal componente curricular, em sua formação, no ensino superior.

$\mathrm{O}$ presente artigo organiza-se em quatro seçóes. A primeira, traz à tona reflexóes sobre o ensinar e aprender na disciplina Métodos e Técnicas do Trabalho Científico. A segunda seção, busca definir e situar o WhatsApp no cenário projetado, como um artefato que é digital e lúdico. $\mathrm{Na}$ terceira, descreve-se o percurso metodológico adotado, para, na quarta seção, apresentar a experiência, seus resultados e análise.

\section{Um novo olhar sobre o ensino de metodologia do trabalho científico}

O envolvimento do estudante do ensino superior com a produção científica acontece (ou deveria acontecer) ainda na graduação, por meio do trabalho colaborativo de investigação junto a seus docentes, bem como ao realizar sua monografia de final de curso.

Nos cursos de pós-graduação lato sensu, a incursão à iniciação científica, quando acontece, circunscreve-se à produção do trabalho de conclusão de curso que, invariavelmente, tem o formato monográfico ou de artigo científico, repetindo o padrão da graduação, com o agravante da carga horária reduzidíssima para o grau de incentivo necessário às produçóes científicas na educação superior, em um momento de pouco fôlego, ânimo, ou desejo de mergulhar em processos investigativos, trazendo da graduação (boa parte dos estudantes) uma complexa relação de amor e ódio com esse componente curricular, personificado como o "estudo das normas da ABNT". ${ }^{1}$

1 Sobre isto, estamos desenvolvendo uma pesquisa intitulada "Amor e ódio: a relação afetivo-emocional de estudantes com a disciplina Metodologia Científica”, para justificar a proposição de uma prática pedagógica para o ensino aprendizagem de "cienciacomleveza". 
Compreende-se como possíveis fatores desencadeadores de tal ambiguidade afetiva: (1) ausência de incentivo à investigação científica a desde educação básica; (2) o grau de complexidade e abstração da área de conhecimento, distanciada do cotidiano dos estudantes; (3) adoção de estratégias didáticas inadequadas para o despertamento do senso crítico, da curiosidade investigativa, mantendo o clássico padrão das exposiçóes dialogadas, intercaladas com exercícios repetitivos sobre o uso das normas da ABNT. Resultado? Estudantes desmotivados, baixo investimento pessoal - de atenção e foco - e envolvimento nas atividades, distanciamento, pouca ou quase nenhuma compreensão da importância dos estudos, especialmente pela proliferação de serviços de "apoio" para a escrita do trabalho monográfico. Finda-se a formação com quase nenhuma aprendizagem significativa sobre o que significa "fazer ciência".

Um breve levantamento em bases de dados Ebsco Host, Redalyc (Rede de Revistas Científicas da América Latina e Caribe); Google Scholar, Portal de Periódicos da CAPES, Scielo revelou a inexistência de experiências pedagógicas e pesquisas, versando sobre novos desenhos pedagógicos para as aulas de Métodos e Técnicas do Trabalho Científico, com a adoção de Metodologias Ativas, Mídias Digitais, Redes Sociais, as TDIC's. Um resultado curioso e preocupante em tempos de e-Science e de open Science (NIELSEN, 2011; LIMA; LIMA, 2013), que requer novos modos de pensar e fazer ciência: colaborativo, compartilhado e público; e em tempos de amplas discussóes sobre a importância nos designs pedagógicos das aulas universitárias.

De acordo com Santos (2011), os avanços tecnológicos abrem campo para novas oportunidades de construção coletiva de conhecimentos, como bem afirmam Saccol, Schlemmer e Barbosa (2011, p. 6), aprender em processos de mobilidade e ubiquidade implica abrir-se às potencialidades que essas tecnologias oferecem. Wikis, blogs, listas de discussão, ambientes virtuais de aprendizagem, aplicativos de mapeamento, web conferência e software de 
autoria de livre acesso apoiados em redes colaborativas e adequada ciberinfraestrutura tecnológica e metodológica permitem o uso, reuso e reprodutibilidade de dados de pesquisa.

Deduz-se, pois, que tanto o uso das mídias, quanto das redes sociais on-line podem contribuir com o desenvolvimento de uma visão integrada e integradora sobre produção científica, bem como desenvolvimento de competências e habilidades investigativas (NIELSEN, 2011; LIMA; LIMA, 2013).

A partir dos princípios estabelecidos no constructo conceitual e reflexivo sobre ensino híbrido (MORAN, 2013, 2015), aprendizagem colaborativa (PIAGET; VYGOTSKY), aprendizagem ativa e ubiquidade, adotou-se uma arquitetura metodológica com uso do Whats $A p p$, pois permite a rápida formação de comunidade on-line, neste caso com o foco no ensino e aprendizagem, intensificando a colaboração mútua.

Mesclar as abordagens de ensino analógicas às digitais, em uma perspectiva híbrida, proporciona ganhos significativos ao processo de ensino aprendizagem. Para Moran (2015), o ensino é híbrido, também, porque não se reduz ao que planejamos institucional e intencionalmente.

Aprendemos por meio de processos organizados, junto com processos abertos, informais. Aprendemos quando estamos com um professor e aprendemos sozinhos, com colegas, com desconhecidos. Aprendemos de modo intencional e de modo espontâneo, quando estudamos e também quando nos divertimos. [...] todos somos aprendizes e mestres, consumidores e produtores de informação (MORAN, 2015, p. 28).

A adoção do WhatsApp como artefato mediador e extensivo à sala de aula, a Whatsaula, permite a organização de um ambiente que promove a aprendizagem pelo viés da colaboração, o que é essencial quando falamos dos novos paradigmas da produção cien- 
tífica, na busca por promover "a comunicação e interação ubíqua - que á ao mesmo tempo em toda parte” (PORTO, 2016)

\section{O WhatsApp como artefato lúdico digital mediador de aprendizagens}

E aî? O que está acontecendo? Qual a novidade? O que há de novo? Estes são alguns dos significados atribuídos à frase em inglês What'sup, um jeito informal de dizer "how are you?" [como você está?]. Esta expressão idiomática - ou gíria para alguns - batizou o aplicativo de mensagens para smartphones (pelo menos inicialmente) que nasce "como uma alternativa ao sistema de SMS, e agora oferece suporte ao envio e recebimento de uma variedade de arquivos de mídia: fotos, vídeos, documentos, compartilhamento de localização e também textos e chamadas de voz" (WHATSAPP, 2017), a partir de uma conexão com a Internet (3G/4G/Wifi).

Institucionalmente definido como um aplicativo de smartphone usado para mensagens instantâneas, o WhatsApp em si não se constitui rede social, aproximando-se mais da definição de mídia social. Contudo, ao permitir gerar incontáveis redes sociais por meio da formação de grupos cuja interação é intensa, muitos lhe atribuem o crédito de "Rede Social online". Para Mattar (2013, p. 27) Rede Social on-line se constitui uma "associação entre pessoas conectadas por diversos motivos, em que as pessoas são afetadas pelas próprias conexóes com outras pessoas". Funcionando em diversas plataformas, tais como iPhone e Android, o aplicativo é amplamente utilizado pelo público, espontaneamente.

Aplicação gratuita e fácil de usar, as conexôes que seus usuários estabelecem - estejam ou não em grupos - permitem o compartilhamento rápido e fácil de objetos de aprendizado, além de comentários, mensagens, avisos etc., o que o torna onipresente, também, nos espaços educativos. Com ele é possível divulgar os tra- 
balhos realizados, enviar mensagens multimídia como fotos, vídeos, áudios, além dos textos de estudo e slides com diversos formatos, em tempo real e instantâneo, desenvolver um trabalho colaborativamente, mesmo que não seja requerido pela instituição de ensino.

Constantemente aprimorado, fortalece as interaçóes no campo do ensino, pois além de aplicativo de comunicação instantânea apenas para dispositivos móveis (smarthphones e tablets), agora possui acesso a computadores pessoais por meio dos navegadores de internet Google Chrome, Mozilla Firefox e Opera.

De acordo com Alves e Porto (2016), o WhatsApp se posiciona como ambiente privilegiado de aprendizagem, quer fora da sala de aula, quanto em sala, promovendo o intercâmbio de informaçóes e a produção colaborativa, estabelecendo-se como alternativas à formação e constante aprendizado dos estudantes, por meio da aprendizagem móvel (Mobile Learning ou m-learning) ubíqua e colaborativa, como uma alternativa eficaz no processo de ensinoaprendizagem (GRIESEMER, 2014).

Além de todo o potencial interacional e comunicativo, o WhatsApp permite, ainda, a presença da dimensão lúdica da aprendizagem, não só pela imersão intensa que requer, mas, também, pela presença de elementos característicos do universo lúdico, por meio dos Emojisao ilustrar os diálogos e permitir uma conversa codificada com símbolos alegres e divertidos, além de favorecer a liberdade de criação. Tratamos de ativar a dimensão lúdica do processo de ensino para além da visão tradicional do lúdico como uso restrito de jogos e brincadeiras em sala.

\section{Método}

Para o desenvolvimento da pesquisa foi adotada a orientaçáo metodológica da pesquisa-ação por sua característica de autorreflexão coletiva contributiva no processo de produção de informaçóes e conhecimentos de uso mais efetivo, inclusive pedagógico, a favo- 
recer condições para ações e transformaçóes de situações dentro da própria escola (THILLENT, 2002). O presente relato retrata uma experiência pedagógica desenvolvida no cerne da disciplina Métodos e Técnicas do Trabalho Científico, em uma turma compartilhada de cursos de Psicopedagogia, Direito Imobiliário e Gestão da Saúde, envolvendo 19 participantes ${ }^{2}$.

A disciplina Métodos e Técnicas do Trabalho Científico, com carga horária total de 20 horas, é componente curricular comum a todos os cursos de pós-graduação da referida Instituição de Esino Superior (IES), operacionalizada em cinco encontros presenciais de 4 horas, contínuos, durante o período de uma semana.

Para a organização dos estudos, os cursistas foram divididos em grupos de 3 a 5 componentes, integrados por seus interesses de investigação. Para registro dos dados, utilizou-se do próprio Whats como Diário de Campo de Virtual, além das demais funcionalidades pedagógicas que ele assumiu, registrando o relato dos estudantes no próprio WhatsApp e questionário on-line estruturado, elaborado na plataforma do Google Docs, para ação-reflexão-intervenção e coleta de dados.

\section{$\mathrm{O}$ WhatsApp integrado ao estudo da metodologia científica}

\section{O relato da experiência e as interaçóes}

As atividades com o WhatsApp iniciaram-se desde o primeiro dia de aula, quando foi esclarecido o desenho da disciplina: as expectativas de aprendizagem, seu objetivo e como seriam deflagradas as atividades para, na sequência, criar o grupo e iniciar a interação.

2 A experiência relatada faz parte de uma ação mais ampla denominada Ciência com Leveza, desenvolvida ao longo de dois anos em turmas de pós-graduação lato sensu das áreas de Educação, Saúde e Gestão, da mesma universidade, e contando com a participaçáo dos estudantes matriculados na disciplina Métodos e Técnicas do Trabalho Científico. 
Os objetivos delimitados para a experiência foram: (1) Compartilhar materiais didáticos; (2) Promover reflexôes sobre os temas constantes na ementa; (3) Produzir colaborativamente os textos do anteprojeto e da prévia do artigo; (4) Fornecer avisos formais e informais; (5) Viabilizar a participação dos estudantes impedidos de frequentar algum dia de aula, por motivos diversos.

Dentre os 19 participantes, dois (13\%) são do sexo masculino e 17 (87\%) do sexo feminino, com faixa etária versando entre 20 a 50 anos. Destes, dois eram estudantes da especialização em Gestão de Saúde; um da especialização em Direito Imobiliário e 16 da especialização em Psicopedagogia.

Ao serem indagados quais redes sociais mais utilizavam em seu dia a dia, o Whats $A p p$ apresentou-se como unanimidade entre os 19 respondentes, seguido do Instagram, depois do Facebook. O Linkedin, o Twitter e o Youtube foram citados com uso mediano ou pouco frequente. Sendo que $90 \%$ dos usuários revelaram que utilizam intensamente o WhatsApp.

Dentre as principais finalidades atribuídas ao uso do WhatsApp, comunicar-se com amigos teve adesão da grande de 17 (94, $4 \%)$ dos estudantes, seguindo de compartilhamento de notícias gerais por $14(77,8 \%)$. Compartilhamento de notícias e materiais do curso foi citado por $13(71,2 \%)$ estudantes, atualização sobre assuntos do curso e disciplina por 13 (72,2\%). Apenas 4 (22,2\%) respondentes afirmaram que estudavam sistematicamente via WhatsApp com grupos.

Ao serem indagados se já haviam participado de alguma atividade pedagógica com uso do WhatsApp 14 (70\%) responderam que nunca haviam participado, 1 (4\%) já vivenciou esta experiência em pós-graduação, 5 (5\%) em cursos livres de extensão, comprovando o uso ainda tímido desta ferramenta no espaço educativo.

O compartilhamento de materiais didáticos deu-se durante todos os encontros. Além de disponibilizar os textos e slide no ambiente virtual, o envio por meio do WhatsApp permitia o acesso 
imediato, sem necessidade de impressão do texto e interação direta com as temáticas que estavam sendo trabalhadas. Os materiais tanto eram enviados pelo professor, quanto pelo grupo, dentro das temáticas da disciplina.

As reflexôes sobre ciência, conhecimento e produção científica deram-se tanto em sala, quanto fora dela, a partir das provocaçóes inseridas pela docente no WhatsApp, conforme pode ser notado nas figuras 1 e 2 .

Figura 1 - Provocação de Figura 2 - Reação à provocação de reflexões extraclasse sobre reflexôes

temas da aula

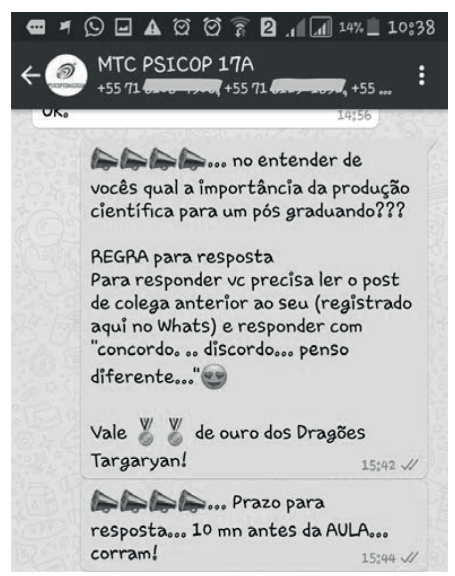

Fonte: Imagem capturada pela autora, grupo do WhatsApp, 2017.

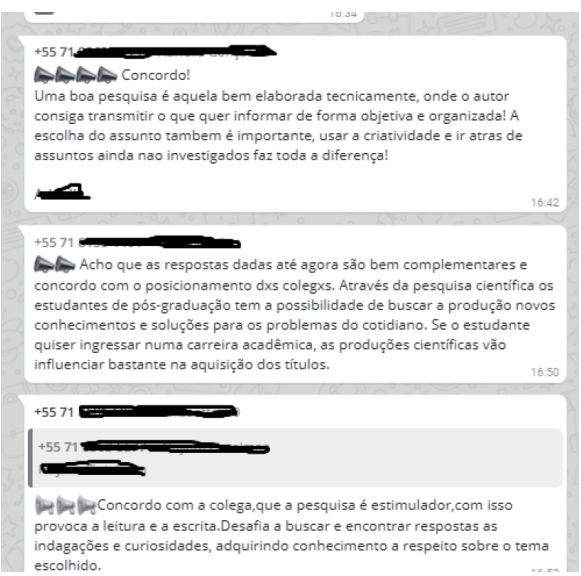

Fonte: Imagem capturada pela autora, grupo do WhatsApp, 2017.

Dos 19 estudantes presentes, 14 reagiram às provocaçóes posicionando-se sobre a questão colocada. Os demais fizeram leitura, mas não responderam. Para preservar o espírito livre e espontâneo do grupo, preferiu-se não arguir sobre os motivos da ausência de interação. A reflexão foi retomada à noite em classe a partir do TED do neurocientista Stuart Firesteinsobre, intitulado "A Busca da Ignorância”. Compreende-se aqui que 
comunicar não é de modo algum transmitir uma mensagem ou receber uma mensagem. Isso é a condição física da comunicaçâa. É certo que para comunicar, é preciso enviar mensagens, mas enviar mensagens não é comunicar. Comunicar é partilhar sentido. (LÉVY, 1999).

A produção colaborativa se fez presente em todos os momentos das aulas e foi intensificada pela criação espontânea de subgrupos de cada equipe, para a construção do roteiro da investigação, dos instrumentos de coleta de dados e, posteriormente, do próprio artigo em sua versão reduzida. Os diálogos capturados nos grupos revelam o desenvolvimento efetivo de competências essenciais para o trabalho colaborativo, tão necessárias à produção científica na atualidade.

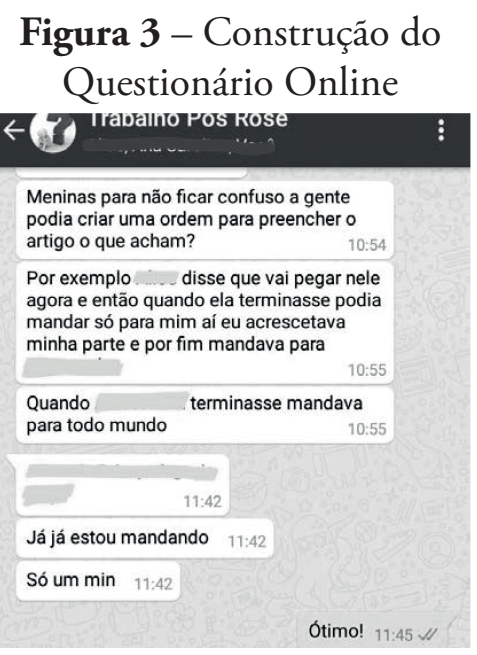

Fonte: Imagem capturada pela autora, grupo do WhatsApp, 2017.

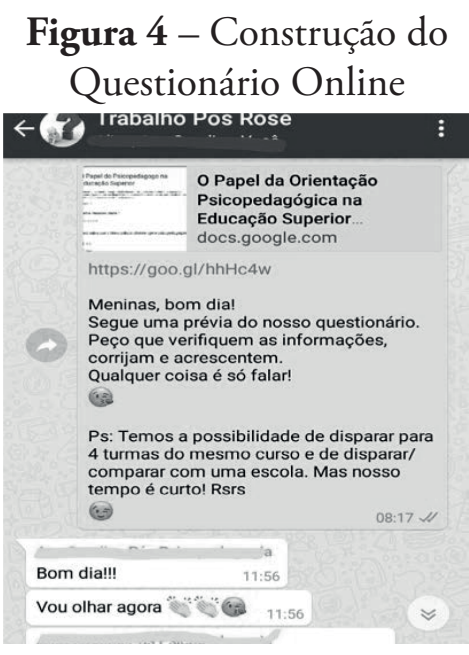

Fonte: Imagem capturada pela autora, grupo do WhatsApp, 2017.

No exemplo deste grupo, além da estruturaçáo do esquema do Projeto, após as reflexôes conceituais sobre metodologia fez-se a 
produção do texto desta seção e a estruturação do instrumento de coletada de dados, com uso da plataforma Google Drive.

Em tempos de mobilidade e de ubiquidade, além das possibilidades previstas relatadas, o uso ativo do WhatsApp durante as aulas viabilizou a participação de estudantes que não puderam deslocar-se para a instituição em um dos dias de aula, concretizando a ideia de mobilidade efetivamente, o perfil híbrido da aula. Foi possível o acesso às atividades desenvolvidas em sala, que foram realizadas remotamente, de forma síncrona e assíncrona.

Sobre a presença do WhatsApp nas aulas, após a experiência desenvolvida, $100 \%$ dos estudantes revelaram acreditar na possibilidade de associação do artefato às aulas. Uma das estudantes afirma:

Sim. É um aplicativo que não tem mais volta e estamos constantemente conectados. Particularmente consigo imaginar um professor que, ao invés de proibir ou chamar atenção do aluno para uso do celular em sala, incluir esse recurso como uma fonte didática na disciplina. Isso é uma forma de demonstrar para os alunos o bom uso desse aplicativo que, sinceramente, veio para ficar e facilita de uma forma inegável nossa vida (ESTUDANTE G, 2017).

Dentre o grupo pesquisado, a presença do artefato foi considerada um benefício para $100 \%$ dos respondentes, por diversas razões, dentre as principais: abranger diversos temas, tira dúvidas; permitir a integração e a partilha de informações; favorecer a interação entre docentes e discentes. Por sua vez, há referência ao cuidado na gestão do grupo, pois facilmente as discussôes podem dispersar das atividades a realizar, dependendo muito do bom senso do usuário.

E quais os pontos frágeis da experiência desenvolvida? Sobre este aspecto os estudantes a dispersão causada em alguns pela quantidade de pessoas participando, simultaneamente; as limitaçóes tecnológicas, tais como celular sem memória, dificuldade em carregar os aparelhos por número reduzido de tomadas, aparelhos mais antigos que travam durante uma carga muito grande de dados, a saber: 
Como ponto frágil, achei a questão de estar online, pois outras pessoas falavam comigo e isso tirava um pouco meu foco. Por mais que eu não quisesse abrir outra conversa, ficava agoniada com a sinalização de mensagens chegando (a curiosidade tbmrs). (ESTUDANTE C).

Percebe-se que a sensaçáo de ubiquidade provocada pelo fato de poder estudar e aprender em qualquer hora e lugar, fruto da versatilidade e rapidez com que as respostas e orientaçóes eram postadas para provocar, questionar ou sanar dúvidas, pode gerar angústia e dificuldade em manter o foco ou concentrar-se, o que requer atenção do docente, tendo em vista as aprendizagens a serem consolidadas no componente curricular, "Infelizmente tive um problema técnico com meu aparelho, onde não pude usar a ferramenta do WhatsApp e tive que pedir a colegas que me enviassem algumas informaçóes por email" (ESTUDANTE L).

E o que sugeririam para aprimorar o desenvolvimento da experiência? Dentre as respostas mais frequentes, 11 (57,9\%) estudantes sugeriram intensificar as atividades de perguntas e respostas pelo aplicativo. $3(15,8 \%)$ sugeriram transformar as atividades de perguntas e respostas em jogos de respostas (Quizz) compartilhado no App e $6(31,6 \%)$ informaram que não saberiam fazer as sugestôes no momento.

Sobre a contribuiçãa da experiência para as aprendizagens específicas de Métodos e Técnicas do Trabalho Científico, os estudantes afirmam:

Por que não me ensinaram dessa forma na graduação? Essa foi a questão que ficou na minha cabeça durante as aulas... Metodologia sempre foi muito complicado para mim e terminava tendo um peso muito grande. Em uma semana não dá para aprender tudo, mas clareou muito e vi o caminho correto, sem precisar fazer malabarismos. E incrivel que eu senti isso muito mais nas atividades onde fiz o "caminho inverso", analisando os dois primeiros artigos e analisando $o$ artigo do grupo dos colegas. (ESTUDANTE B). 
O depoimento da estudante B faz coro aos demais, salientando a necessidade de articular e desenvolver práticas pedagógicas em ressonância com as aprendizagens necessárias ao momento atual. Os estudantes participam de uma comunidade interativa, articulada, colaborativa e solidária, posicionando-se como colaboradores interativos, fortalecendo a construção e divulgação de conhecimentos essenciais às aprendizagens a serem consolidadas com o estudo do componente curricular, com a consolidação de nova forma de perceber a produção científica.

\section{Conclusão}

A análise das interaçóes revelou uma relação positiva dos estudantes com a abordagem metodológica adotada. Para além dos objetivos propostos para a integração do Whats $A p p$ revelou-se uma grande contribuição da experiência para estabelecer uma atmosfera positiva e desenvolver o sentimento de pertença na classe, especialmente em uma turma que estava iniciando o curso, sendo esta a segunda disciplina; o fortalecimento do diálogo, utilização e partilha das aprendizagens mútuas.

A abordagem favoreceu o estudo da temática de forma leve e positiva, revelando ser possível fazer aprender a "ciência com leveza”. Evidenciou-se, também, algumas vantagens do WhatsApp sobre as demais redes e mídias sociais para uso nas dinâmicas das aulas: além de seu baixo custo, simplicidade, acessibilidade, eficiência e linguagem natural (CHURCH; DE OLIVEIRA, 2013) é uma das mídias sociais mais utilizadas, senão a mais utilizada, de forma espontânea, por estudantes, tanto jovens, quanto adultos, cruzando linhas divisórias entre o lugar do docente e do discente, contribuindo com a ação autônoma e colaborativa dos estudantes, por sua forma de gestão, concretizando a existência de outros momentos de aprendizagem que não apenas aqueles estabelecidos em aula. 
Ao favorecer um contato mais rico, dinâmico e interativo com um conteúdo denso e carregado de subjetividade, muitas vezes percebido como maçante especialmente pela sua dissociação ao cotidiano dos estudantes, as estratégias adotadas com o artefato permitiram um mergulho intenso nas atividades do componente curricular, além de uma percepção mais efetiva do que significa fazer ciência e de forma colaborativa, permitindo a promoção de aprendizagens colaborativas, móvel e ubíqua.

A abertura e o estilo das reflexóes que se estabelecem, a possibilidade de integrar linguagem lúdica dos emojis, certamente permitiu uma maior abertura e aproximação entre os próprios discentes e entre estes e os docentes, estabelecendo uma atmosfera positiva, bem como uma sensação de pertencimento.

É imprescindível que o(s) iniciações científicas dos estudantes ultrapasse o mecanicismo estanque e linear marcantes especialmente na concepção de produção científica subjacente aos Trabalhos Finais de Curso, constituindo-se experiências potenciais para construção social desse espaço de saber/poder, espaço esse que produz identidades particulares e coletivas, dando forma, sentidos e significado às singularidades culturais (WEBER; SANTOS; SANTOS, 2012).

Foram apontadas as limitaçóes e dificuldades que de certa forma podem comprometer o objetivo de tornar o aplicativo, em parte extensiva e complementar a sala de aula, problemas de ordem financeira e técnica podem excluir alunos que não dispóem de smartphones, planos de internet em seus celulares ou internet em suas residências, dificultando o uso e principalmente o acesso dos alunos às ferramentas e recursos digitais disponíveis.

Há desafios, lidar com a dispersão, cuidar da retomada das discussōes, identificar as "não participações" para potencializá-las, imersão profunda rompendo, muitas vezes, a barreira do pessoal e do profissional, além da exigência de mais horas de trabalho do que as regularmente estabelecidas em contratualmente, um grande 
desafio para todos os docentes. Estas questóes requerem atenção para que os docentes não se sintam sobrecarregados em seu cotidiano. Cabe lembrar que o objeto deste artefato (e muitos outros) é contribuir para o estabelecimento de uma mediação eficiente do conhecimento, com a otimização dos tempos em sala de aula e fora dela, além de permitir o aprimoramento das açóes pedagógicas que desenvolve. E não substituir a presença do docente.

Os princípios da aprendizagem colaborativa assegurados por meio da proposição e realização de atividades mediadas pelo artefato, a interação social e o "engajamento" múutuo enfatizam a importância da interação entre os pares para a efetiva consolidação da aprendizagem. Interação, colaboração e vivências práticas são essenciais para os processos de construção de um novo olhar sobre o fazer ciência.

Quanto mais interaçóes, envolvimento em atividades práticas e partilha de descobertas, mais significativas, duradouras e profundas são as aprendizagens. Aliado a isto temos o componente afetivo como grande deflagrador do envolvimento, participação, mobilização dos estudantes em seu percurso pedagógico. Afinal, compreende-se que aprendemos e ensinamos em muitos outros espaços e lugares, tudo isso graças à mediação das mídias digitais, que canalizam, armazenam e distribuem o saber produzido individual e coletivamente.

\section{Referências}

ALVES, A.L.; PORTO, C. de M. WHATSAULA: tudo híbrido e misturado. In: CONGRESSO NACIONAL DE EDUCAÇÃO - CONEDU. 3., 2016, Natal. Anais... Natal: Realize Eventos, 2016. Disponível em: <http://www.editorarealize.com.br/ revistas/conedu/trabalhos/TRABALHO_EV056_MD1_SA19_ ID2339_15082016085521.pdf>. Acesso em: 10 jun. 2017. 
GRIESEMER,J.A. Using-social-media-to-enhance-students-learningexperiences. 2014. Disponível em: <http://asq.org/edu/index.html http://rube.asq.org/edu/2014/03/best-practices/using-social-mediato-enhancestudents-learning-experie>. Acesso em: 10 jun. 2017.

LÈVY, Pierre. Cibercultura. São Paulo: 34, 1999.

LÈVY, Pierre. As tecnologias da inteligência: o futuro do pensamento na era da Informática. Sáo Paulo: 34, 1996.

LÈVY, Pierre. Árvores de Saúde. Interface (Botucatu), Botucatu, v. 3, n. 4, p. 143-156, feb. 1999. Disponível em: <http:// www.scielo.br/scielo.php?script=sci_arttext\&pid=S141432831999000100012\&lng=en\&nrm=iso >. Acesso em: 4 jul. 2017.

LIMA, J.A.L.; LIMA, V.A. O. Do open source ao open education: novos conceitos para educomunicação. In: CONFERÊNCIA BRASILEIRA DE ESTUDOS EM COMUNICAÇÃO E MERCADO - ECOM, 3., 2013, Campina Grande. (Anais... Campina Grande, 2013.

MORAN, José Manuel. Educação híbrida: um conceito-chave para a educação hoje. In: MORAN, José Manuel. A educaçáo que desejamos: Novos desafios e como chegar lá. 5. ed. Campinas: Papirus, 2013.

MORAN, J. Educação híbrida. Um conceito-chave para a educação, hoje. In: BACHIC, Lilian; TANZI NETO, Adolfo; TREVISANI, Fernando de Mello (Org.). Ensino hibrido: personalização e Tecnologia na Educação. Porto Alegre: Penso. 2015.

NIELSEN, M. Reinventing discovery: the new era of networked science. Princeton: University, 2011 
SACCOL, Amarolinda; SCHLEMMER, Eliane; BARBOSA, Jorge. M-Learning e U-Learning: novas perspectivas de aprendizagem móvel e ubíqua. São Paulo: Pearson Prentice Hall, 2011.

SANTAELLA, Lúcia. Desafios da ubiquidade para a educação. Revista Ensino Superior Unicamp, Campinas, n.9, abr./ jun. 2013. Disponível em: <http://www.revistaensinosuperior. gr.unicamp.br/artigos/desafios-da-ubiquidade-para-aeducacao $>$. Acesso em: 10 jun. 2017

SANTOS, Edméa. Educação Online para além da EAD: um fenômeno da Cibercultura. In: Actas do X Congresso Internacional Galego-Português de Psicopedagogia. Braga: Universidade do Minho, 2009.

SANTOS, Edméa. A Cibercultura e a Educação em Tempos de Mobilidade e Redes Sociais: conversando com os cotidianos. In: FONTOURA, Helena; SILVA, Marco (Org.). Práticas pedagógicas, linguagem e mídias: desafios à pós-graduação em educação em suas múltiplas dimensóes. Rio de Janeiro: ANPED Nacional, 2011. p. 138-160. 


\section{SOBRE OS AUTORES}

Alexandre Meneses Chagas. Mestre em Educação pela Universidade Tiradentes (Unit), pós-graduado em Docência e Tutoria On-line, publicitário pela Unit, professor do curso de Comunicação Social da Unit, membro do Grupo de Estudo e Pesquisa Comunicação, Educação e Sociedade (GECES). Coordenador da Produção de Conteúdos Midiáticos para EAD/Unit; Editor Gerente do Portal de Periódicos do Grupo Tiradentes; especialista em Curadoria de Conteúdos Digitais e no sistema de submissão SEER (OJS). Áreas de atuação profissional: educação e cibercultura, tecnologia digital na educação, produção de conteúdo para educação online e EAD e curadoria de conteúdo. E-mail: profamchagas@gmail.com

Alexsandra Barbosa. Pedagoga da Universidade do Estado do Rio de Janeiro (UERJ). Mestranda do Proped/UERJ e membro do Grupo de pesquisa: Docência e Cibercultura - GPDOC/UERJ. E-mail: b.s.alexsandra@gmail.com

André Luiz Alves. Bolsista PROCAPS/UNIT do Mestrado em Educação - Linha "Educação e Comunicação", na Universidade Tiradentes (PPED/UNIT/SE). Pesquisador do Grupo de Pesquisa Educação, Tecnologia da Informação e Cibercultura (GETIC/ UNIT/CNPq). Possui MBA em Marketing (UNIT/SE). Especialista em Educação a Distância: Gestão e Tutoria (UNIASSELVI/ SC) e em Comunicação Organizacional e Novas Tecnologias UNIT(SE). Graduado em Comunicação Social: Publicidade e Propaganda (UNIT/SE). E-mail: andrealves.unit@gmail.com 
Andrea Brandão Lapa. Professora do Programa de Pós-Graduação em Educação da Universidade Federal de Santa Catarina (PPGE/ UFSC). Coordenadora do Laboratório de Novas Tecnologias (Lantec/CED/UFSC). Líder do grupo de pesquisa COMUNIC, com pesquisas em: redes sociais e formação do sujeito; educação mediada por TIC; formação de professores para a integração de tecnologias; docência na EaD. E-mail: andrea.lapa@ufsc.br

Arlene Araújo Domingues Oliveira. Licenciada em Informática pela Universidade Tiradentes (UNIT). Graduanda em Pedagogia pela Universidade Federal de Sergipe (UFS). Bolsista do Programa de Iniciação Científica do CNPq. Membro do Grupo de Pesquisa ECult - Educação e Culturas Digitais (UFS/CNPq/ECult). E-mail: arlene.morena@gmail.com

Carloney Alves de Oliveira. Professor Adjunto do Curso de Pedagogia na área de Saberes e Metodologias do Ensino da Matemática da Universidade Federal de Alagoas (UFAL). Doutor em Educação (UFAL). Professor vinculado ao Programa de Pós-Graduação em Ensino de Ciências e Matemática (PPGECIM) da UFAL. Membro do Grupo de Pesquisa em Educação Matemática. E-mail: carloneyalves@gmail.com

Cristiane de Magalhães Porto. Doutora Multidisciplinar em Cultura e Sociedade da Universidade Federal da Bahia (UFBA). Mestrado em Letras e Linguística - UFBA. Bolsista de Produtividade em Pesquisa nível 2 do CNPq. Atualmente, é pesquisadora colaboradora do Instituto de Tecnologia e Pesquisa. É professora da categoria Professor Pleno da Pós-Graduação (PPPG) da Universidade Tiradentes (Unit), atuando como docente do Programa de Pós-Graduação em Educação, do Curso de Comunicação Social e editora científica desta Instituição. Desde setembro de 2016 está fazendo estágio Pós-Doutoral no Programa de Pós-Graduação 
em Educação da UERJ. Líder e pesquisadora do Grupo de Pesquisa Educação, Tecnologia da Informação e Cibercultura (GETIC/ CNPq).E-mail: crismporto@gmail.com

Edméa Oliveira dos Santos. Pedagoga pela Universidade Católica de Salvador (UCSAL), Mestre e Doutora em Educação pela UFBA. Pós-doutora em e-learning e EAD pela UAB-PT. Professora adjunta da Faculdade de Educação da UERJ. Atua no Programa de Pós-Graduação em Educação (PROPED/UERJ). Linha de Pesquisa: Cotidianos, redes educativas e processos culturais. Líder do Grupo de Pesquisa Docência e Cibercultura (GPDOC/UERJ). Membro do Laboratório de Imagem da UERJ. Membro do GT 16: Educação e Comunicação; da ANPED e da Associação de Pesquisadores em Cibercultura. - ABCIBER. Atua na formação inicial e continuada de professores e pesquisadores. Áreas de atuação: educação e cibercultura, formação de professores e pesquisadores, informática na educação, educação online, EAD, currículo, didática, pesquisa e práticas pedagógicas. Site institucional: www.proped.pro.br Ambiente virtual: www.docenciaonline.pro.br E-mail: edmeabaiana@ gmail.com

Edvaldo Souza Couto. Doutor em Educação (UNICAMP), Professor Titular na Faculdade de Educação da Universidade Federal da Bahia (UFBA). Pesquisador e bolsista em produtividade nível 2 do CNPq. Atua na Graduação e no Programa de Pós-Graduação em Educação. É um dos coordenadores do Grupo de pesquisa em Educação, Comunicação e Tecnologias (GEC).E-mail: edvaldo@ufba.br

Elbênia Marla Ramos Silva. Bolsista Capes do Doutorado Pleno no Exterior no Programa Informação e Comunicação em Plataformas Digitais (ICPD) no Departamento de Comunicação e Arte (DECA) da Universidade de Aveiro (UA) - Portugal. Mestre em Educação pelo Programa de Pós-Graduação em Educação da Uni- 
versidade Tiradentes (PPED/Unit), graduada em Comunicação Social - Jornalismo pela Unit. Membro do grupo de pesquisa sobre Comunicação, Educação e Sociedade - GECES e da Unidade de Investigação DigiMedia (CIC.Digital). Publica artigos nas áreas de Comunicação e Educação, Tecnologias digitais e Formação de professores para as TDIC. E-mail: elbenia.ramos@ua.pt

Felipe da Silva Ponte de Carvalho. Doutorando em Educação pelo ProPed/Uerj. Membro do Grupo Docência e Cibercultura (Gpdoc/Uerj). Docente online da disciplina de "Informática na Educação" do curso de Pedagogia a distância Uerj/Cederj/UAB. Email: felipesilvaponte@gmail.com

Gilka Girardello. Graduada em Comunicação pela UFRGS, com Mestrado em Ciências Humanas pela New School for Social Research de Nova York e Doutorado em Ciências da Comunicação pela USP. Foi pesquisadora visitante (Fulbright/Capes) no Programa de Educação da City University of New York. Professora associada da UFSC, atua na graduação em Pedagogia e no Programa de PósGraduação em Educação, dentro da Linha Educação e Comunicação. E-mail: gilka@floripa.com.br

Gilson Pereira dos Santos Júnior. Mestre em Ciência da Computação pela Universidade Federal de Campina Grande (UFCG). Professor do Curso de Bacharelado em Sistemas de Informação do Instituto Federal de Educação, Ciência e Tecnologia de Sergipe (CBSI/IFS). E-mail: gilson.pereira@ifs.edu.br

Huber Kline Guedes Lobato. Mestre em educação pelo Programa de Pós-Graduação em Educação da Universidade do Estado do Pará (UEPA/2015). Professor Assistente do Instituto de Letras e Comunicação da Universidade Federal do Pará e coordenador do Curso de Letras Libras e Língua Portuguesa (L2) para surdos 
da UFPA. Especialista em Educação Especial pela Faculdade de Educação Montenegro (FAEM/2010). Licenciado em Pedagogia (UFPA/2006). Tem experiência na área da educação com ênfase em Educação Especial, Educação Inclusiva, principalmente em Educação de Surdos. E-mail: huberkline@gmail.com

J. António Moreira. Doutor e Mestre em Ciências da Educação pela Universidade de Coimbra. Pós-Doutorado em Tecnologias Educacionais e da Comunicação também pela Universidade de Coimbra. Possui Curso de Mestrado em Multimédia pela Universidade do Porto. É Professor Auxiliar, de nomeação definitiva, no Departamento de Educação e Ensino a Distância (DEED) da Universidade Aberta (UAb). Atualmente é Diretor da Delegação Regional do Porto da UAb e Coordenador da Unidade de Desenvolvimento dos Centros Locais de Aprendizagem (UMCLA) da mesma universidade. É Coordenador Científico da Unidade Móvel de Investigação em Estudos do Local (ELO) e investigador no Grupo de Políticas e Organizaçóes Educativas e Dinâmicas Educacionais (GRUPOEDE) do Centro de Estudos Interdisciplinares do Século XX (CEIS20) da Universidade de Coimbra e no Laboratório de Educação a Distância e eLearning (LE@d) da UAb. E-mail: jmoreira@uab.pt

Joana Dourado França de Souza. Mestranda em Educação pelo PPGE-UFBA; Especialista em Coordenação Pedagógica pela Escola de Gestores Faculdade de Educação da Universidade Federal da Bahia (FACED/UFBA); Graduada em Pedagogia FACED-UFBA. É bolsista do Grupo de Pesquisa em Educação, Comunicação e Tecnologia - GEC. Atualmente, investiga pedagogias e modos de ser de jovens no recurso Instagram Stories do aplicativo Instagram. E-mail: joana.dourado@yahoo.com.br 
Kaio Eduardo de Jesus Oliveira. Doutorando em Educação pela Universidade Tiradentes (UNIT). Possui Mestrado em Educação pela Unit. Graduação em Geografia licenciatura pela Unit. Especialização em Tecnologias Educacionais pela Unit. Foi professor de Geografia no ensino básico e professor convidado da Pós-Graduação (lato sensu) da Universidade Tiradentes. Pesquisador do Grupo de Pesquisa Educação, Tecnologia da Informação e Cibercultura (GETIC/CNPq).E-mail: kaioeduardojo@gmail.com

Lígia Fontana. Pedagoga pela Universidade Mackenzie e Lato-Sensu nas áreas: Psicopedagogia Educacional, Tecnologia Educacional, Mídias na Educação, Design Instrucional e Planejamento, Implantação e Gestão de Cursos a Distância. Mestranda da Universidade Aberta de Portugal em Lisboa no curso Comunicação Educacional e Mídias Digitais. É docente da educação superior no curso de Pedagogia em universidades da rede particular de ensino e atua em projetos educacionais que envolvam temáticas no âmbito das tecnologias digitais aplicadas à educação. Desenvolve investigação no Laboratório de Educação a Distância e Elearning (LE@D - UAb) sobre temas da psicologia e pedagogia da educação online e sobre utilização das tecnologias digitais em contextos educativos formais e não formais. E-mail: prof.ligiamonteiro@gmail.com

Lúcia Amante. Doutorada em Ciências da Educação. É Professora na Universidade Aberta - Portugal, atuando em cursos de graduação e pós-graduação. Coordena o mestrado em Comunicação Educacional e Média Digitais. Integra o Laboratório de Educação a Distância e Elearning da Universidade Aberta e desenvolve a sua investigação na área da Educação a Distância, (Psicologia e Pedagogia da Educação Online) e utilização pedagógica das tecnologias digitais. Integrou a equipe que delineou o modelo pedagógico virtual da Universidade Aberta e tem diversas publicaçóes sobre problemáticas relativas aos novos contextos de aprendizagem que emergem na sociedade em rede. E-mail: luciaamante@gmail.com 
Lynn Alves. Bolsista de Produtividade Desenvolvimento Tecnológico e Extensão Inovadora do $\mathrm{CNPq}$ - Nível 2, possui graduação em Pedagogia pela Faculdade de Educação da Bahia (1985), Mestrado (1998) e Doutorado (2004) em Educação pela Universidade Federal da Bahia. O Pós-doutorado foi na área de Jogos eletrônicos e aprendizagem pela Università degli Studi di Torino, na Itália. Atualmente é professora e pesquisadora do SENAI-CIMATECDepartamento Regional da Bahia (Núcleo de Modelagem Computacional) e da Universidade do Estado da Bahia. Tem experiência na área de Educação, realizando investigaçóes sobre Cultura digital e suas interfaces, especialmente sobre os seguintes temas: jogos eletrônicos, interatividade, mobilidade e educação. Coordena os projetos de pesquisa e desenvolvimento em jogos digitais como: Tríade (FINEP/FAPESB/UNEB), Búzios: ecos da liberdade (FAPESB), Guardiōes da floresta (CNPq, FAPESB, Proforte), Brasil 2014: rumo ao Hexa (SEC-Ba), Insitu (SEC-BA), Industriali (SEC-BA), Games studies (FAPESB), DOM (SEC-Ba), Janus (SEC-Ba) e Gamebook (CAPES/FAPESB). Organiza e coordena há onze anos o Seminário de Jogos Eletrônicos, Educação e Comunicação - construindo novas trilhas. E-mail: lynnalves@gmail.com

Mayra Ribeiro. Professora Doutora da Faculdade de Educação na Universidade do Estado do Rio Grande do Norte (UERN). Grupo de pesquisa: Formação e Profissionalização do Educador.

E-mail: mayra.rfr@gmail.com

Renata Moraes de Oliveira. Graduada em Letras - Língua Portuguesa pela Universidade Federal do Pará (UFPA/2017). Participa como voluntária no Projeto de Pesquisa intitulado: "A Pesquisa no Curso de Letras Libras e Língua Portuguesa como segunda língua para Surdos da Universidade Federal do Pará”. Discute, pesquisa e escreve sobre os seguintes temas: Educação de Surdos; Perspectiva Vygotskyana; Tecnologia e Surdez.

E-mail: rmorenata85@gmail.com 
Ronaldo Nunes Linhares. Possui graduação em História pela Universidade Federal de Sergipe (UFS), Mestrado em Educação pela UFS e Doutorado em Ciências da Comunicação pela Universidade de São Paulo. Fez estágio pós-doutoral na Universidade de Aveiro em Portugal. Atualmente, é professor PPGII-II do Programa de Pós Graduação em Educação da Universidade Tiradentes - PPED/ UNIT. E-mail: nuneslinhares.ronaldo8@gmail.com

Rosemary Lacerda Ramos. Doutora em Educação (UFBA). Estágio Pós-doutoral em Educação e Contemporaneidade (UNEB). Licenciada em Educação Artística (UCSAL). Professora e pesquisadora do ISEO; Pós-Graduação da UNIFACS e UNIJORGE. Membro do Centro de Pesquisa Comunidades Virtuais (UNEB); do Grupo de Pesquisa FORMACCE (UNEB) e do GEPPEL (UFBA) - DGP/CNPQ. Atua na formação inicial e continuada de professores e pesquisadores da Educação Básica e Ensino Superior, nas seguintes áreas de conhecimento: Aprendizagem; Arte; Ludicidade e Tecnologia; Currículo; Didática e práticas pedagógicas. E-mail: rosel.ramos@gmail.com.

Rosemary Santos. Doutora e Mestre em Educação pela UERJ. Professora da Rede Municipal de Educação Duque de Caxias. Formada em Letras e Pedagogia, Pós-Graduada em Docência do Ensino Superior (UCAM) e Informática Aplicada à Educação (UERJ). Professora Adjunta do Departamento de Formação de Professores da Faculdade de Educação da Baixada Fluminense (FEBF-UERJ). Vice-coordenadora do Grupo de Pesquisa Docência e Cibercultura - GPDOC/ UERJ, Tutora de Educação a Distância. E-mail: brisaerc@gmail.com

Rubens Alexandre de Oliveira Faro. Possui especialização em Língua Brasileira de Sinais (Libras) pela Faculdade de Educação Montenegro (FAEM/2011). É graduado em Letras - Libras pela Universidade Federal de Santa Catarina (UFSC/2012) e graduado em 
Pedagogia pela Universidade Estadual Vale do Acaraú (UVA/2005). Atualmente é Professor Auxiliar da Universidade Federal do Pará Campus Castanhal, atuando no âmbito do ensino, pesquisa e extensão com os seguintes temas: Surdez, Acessibilidade e Tradução e Interpretação de Língua de Sinais. E-mail: rubfaro@hotmail.com

Sara Dias Trindade. Doutora em História: Didática da História. Professora Auxiliar Convidada no Departamento de História, Estudos Europeus, Arqueologia e Artes da Faculdade de Letras da Universidade de Coimbra. Investigadora no Grupo Humanidades Digitais do Centro de Estudos Interdisciplinares do século XX (CEIS20) da Universidade de Coimbra, integrando, atualmente, a equipa de coordenação do referido Centro. É ainda Investigadora Colaboradora na Unidade Móvel de Investigação em Estudos do Local da Universidade Aberta (UAb). É membro do Núcleo de Estudos de Pedagogia do Ensino Superior (NEPES) do CEIS20 e do Laboratório de Tecnologias Educativas (LabTE) da Faculdade de Psicologia e Ciências da Educação da Universidade de Coimbra. É, também, formadora acreditada pelo CCPFP para as áreas do Ensino da História e das Tecnologias Educativas. E-mail: trindade.sara@gmail.com

Simone Lucena. Doutora em Educação. Professora do Departamento de Educação e do Programa de Pós-Graduação em Educação da Universidade Federal de Sergipe (UFS). Coordenadora de área do Pibid do curso de Pedagogia da UFS, Campus Prof. Alberto de Carvalho. Líder do Grupo de Pesquisa Educação e Culturas Digitais (UFS/CNPq/Ecult). E-mail: slucen@yahoo.com.br

Tânia Lúcia Maddalena. Doutoranda em Educação pelo Proped/ UERJ, membro do Grupo Docência e Cibercultura (GPDOC/UERJ). Mestre em Educação pela UNICAMP. Especialista em Educação e Novas Tecnologias pela FLACSO/Argentina e Bacharel em Ciências da Educação pela UNLP/Argentina. E-mail: tlmaddalena@gmail.com 
Velda Torres. Comunicóloga, Publicitária, Doutoranda e Mestra em Cultura e Sociedade (POSCULTURA/UFBA), Especialista em Gestão da Comunicação (ECA/USP) e em Marketing Estratégico (FACULDADE RUY BARBOSA). Consultora de Comunicação e Professora universitária, com experiência docente nas disciplinas Teorias da Comunicação, Direção de Arte, Redação Publicitária, Criação e Elaboração de Campanha, Planejamento de Comunicação, Orientação de Projeto Experimental (TCC), Administração Publicitária, Estudos Socioantropológicos, Cultura e Sociedade, Tecnologia e Sociedade, Metodologia da Pesquisa e Educação e Tecnologia. Pesquisadora da Cultura de Consumo Infantojuvenil, realizando investigações sobre hábitos, práticas e comportamentos de consumo dos pré-adolescentes, com ênfase nos estudos sobre cultura de consumo e sua relação com os produtos midiáticos. Integra o Grupo de Estudo e Pesquisa de Práticas e Produtos da Cultura Midiática (IHAC / /UFBA) e o Grupo de Pesquisa Comunidades Virtuais (UNEB). Possui interesse por pesquisa e docência em áreas relacionadas à Comunicação Social; Culturas Contemporâneas; Comportamento do Consumidor; Educomunicação. E-mail: veldatorres@uol.com.br 


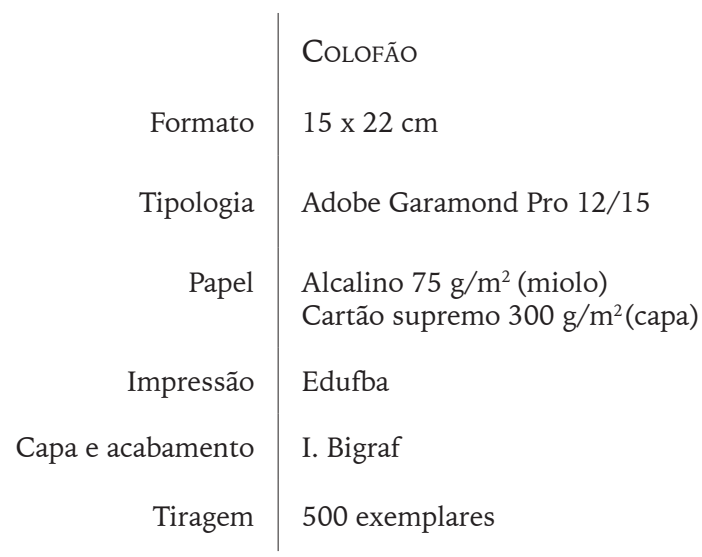

